

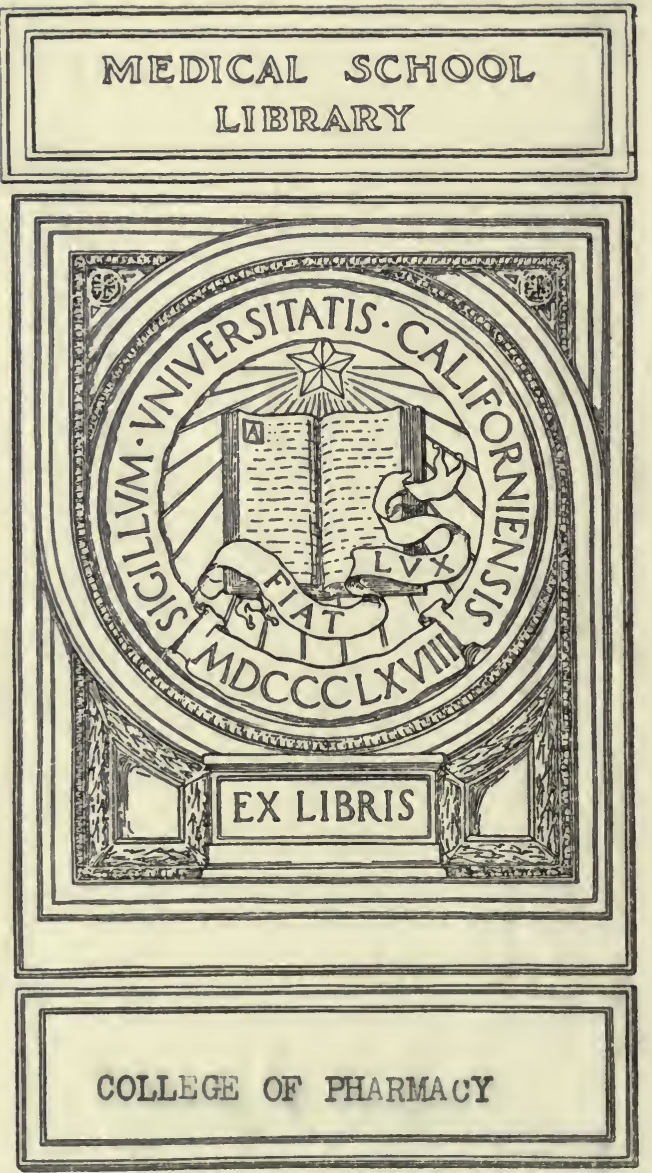




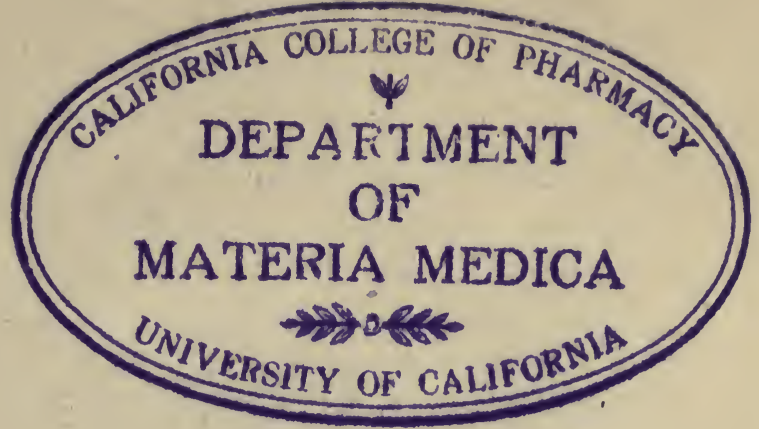


Digitized by the Internet Archive in 2007 with funding from Microsoft Corporation 


\title{
HISTOLOGY OF
}

\section{MEDICINAL PLANTS}

\author{
BY \\ WILLIAM MANSFIELD, A.M., Phar.D. \\ Professor of Histology and Pharmacognosy, College of \\ Pharmacy of the City of New York \\ Columbia University
}

TOTAL ISSUE, FOUR THOUSAND

NEW YORK

JOHN WILEY \& SONS, INC.

London: CHAPMAN \& HALL, Limited 
Copyright, 1916, by

WILLIAM MANSFIELD

$9 / 20$ 


\section{PREFACE.}

THE object of the book is to provide a practical scientific course in vegetable histology for the use of teachers and students in schools and colleges.

The medicinal plants are studied in great detail because they constitute one of the most important groups of economic plants. The cells found in these plants are typical of the cells occurring in the vegetable kingdom; therefore the book should prove a valuable text-book for all students of histology.

The book contains much that is new. In Part II, which is devoted largely to the study of cells and cell contents, is a new scientific, yet practical, classification of cells and cell contents. The author believes that his classification of bast fibres and hairs will clear up much of the confusion that students have experienced when studying these structures.

The book is replete with illustrations, all of which are from original drawings made by the author. As most of these illustrations are diagnostic of the plants in which they occur, they will prove especially valuable as reference plates.

The material of the book is the outgrowth of the experience of the author in teaching histology at the College of Pharmacy of the City of New York, Columbia University, and of years of practical experience gained by examining powdered drugs in the laboratory of a large importing and exporting wholesale drug house.

The author is indebted to Ernest Leitz and Bausch \& Lomb Optical Company for the use of cuts of microscopic apparatus used in Part I of the book.

The author also desires to express his appreciation to Professor Walter S. Cameron, who has rendered him much valuable aid.

William Mansfield.

Columbia University,

September, 1916. 



\title{
CONTENTS
}

PART I

\section{Simple and Compound Microscopes and Micro- SCOPIC TECHNIC}

\author{
CHAPTER I
}

THE SIMPLE MICROSCOPES

PAGE

Simple microscopes, forms of .

\section{CHAPTER II}

\section{COMPOUND MICROSCOPES}

Compound microscopes, structure of . . . . . . . . . . 7

Compound microscopes, mechanical parts of . . . . . . . 7

Compound microscopes, optical parts of . . . . . . . . . . 9

Compound microscopes, forms of . . . . . . . . . . . 12

\section{CHAPTER III}

MICROSCOPIC MEASUREMENTS

Ocular micrometer

Stage micrometer

Mechanical stage

Micrometer eye-pieces .

Camera lucida

Drawing apparatus

Microphotographic apparatus

CHAPTER IV

HOW TO USE THE MICROSCOPE

Illumination

Micro lamp .

Care of the microscope.

Preparation of specimens for cutting 
Paraffin imbedding oven

Paraffin blocks

Cutting sections

Hand microtome

Machine microtomes

\section{CHAPTER V}

REAGENTS

Reagent set .

Measuring cylinder

\section{CHAPTER VI}

HOW TO MOUNT SPECIMENS

Temporary mounts

Permanent mounts

Cover glasses

Glass slides

Forceps

Needles

Scissors

Turntable

Labeling .

Preservation of mounted specimens

Slide box

Slide tray

Slide cabinet

\section{PART II}

\section{Tissues, Cells and Cell Contents}

\section{CHAPTER I \\ THE CELL}

Typical cell .

Changes in a cell undergoing division . . . . . . . . . . 55

Origin of multicellular plants .

CHAPTER II

THE EPIDERMIS AND PERIDERM

Leaf epidermis Testa epidermis Plant hairs 
Forms of hairs

Papillæ

Unicellular hairs

Multicellular hairs

Periderm

Cork periderm

Stone cell periderm

Parenchyma and stone cell periderm

CHAPTER III

\section{MECHANICAL TISSUES}

Bast fibres

Crystal bearing bast fibres

Porous and striated bast fibres

Porous and non-striated bast fibres

Non-porous and striated bast fibres

Non-porous and non-striated bast fibres

Occurrence of bast fibres in powdered drugs

Wood fibres .

Collenchyma cells

Stone cells

Endodermal cells

Hypodermal cells

\section{CHAPTER IV}

ABSORPTION TISSUE

Root hairs

I2I

\section{CHAPTER V}

CONDUCTING TISSUEE

Vessels and tracheids

Annular vessels .

Sclariform vesscls

Reticulate vessels

Pitted vessels

Pitted vessels with bordered pores

Sieve tubes

Sicve plate

Medullary bundles, rays and cells Medullary ray bundle

The medullary ray .

The medullary ray cell 
Structure of the medullary ray cells

Arrangement of the medullary ray cells in the medullary ray

Latex tubes .

Parenchyma

Cortical parenchyma

Pith parenchyma

Leaf parenchyma

Aquatic plant parenchyma

Wood parenchyma .

Phloem parenchyma

Palisade parenchyma

\section{CHAPTER VI \\ AERATING TISSUE}

Water pores

Stomata

Relation of stomata to the surrounding cells

Lenticels

Intercellular spaces

\section{CHAPTER VII}

SYNTHETIC TISSUE

Photosynthetic tissue

Glandular tissue

Glandular hairs

Secretion cavities

Schizogenous cavities

Lysigenous cavities

Schizo-lysigenous cavities

\section{CHAPTER VIII}

STORAGE TISSUE

Storage cells

Storage cavities

Crystal cavities

Mucilage cavities

Latex cavities

Oil cavity

Glandular hairs as storage organs

Storage walls 


\section{CHAPTER IX}

\section{CELL CONTENTS}

Chlorophyll .

Leucoplastids

Starch grains

Occurrence

Outline .

Size .

Hilum

Inulin

Nature of hilum

PAGE

182

I 83

I83

I 84

I 85

I 85

I 85

I 88

194

194

I96

196

196

197

197

197

198

I98

200

200

200

202

Rosette crystals

205

210

210

215

\section{PART III}

\section{Histology of Roots, Rhizomes, Stems, Barks, Woods, Flowers, Fruits and SeEdS}

\section{CHAPTER I}

\section{ROOTS AND RHIZOMES}

Cross-section of pink root .

Cross-section of ruellia root

Cross-section of spigelia rhizome

Cross-section of ruellia rhizome

Powdered ruellia root 


\section{CHAPTER II}

\section{STEMS}

Herbaceous stems

Cross-section, spigelia stem

Ruellia stem

Powdered horehound .

Powdered spurious horehound

Insect flower stems

CHAPTER III

WOODY STEMS

Buchu stem .

Mature buchu stem

Powdered buchu stem

\section{CHAPTER IV}

\section{BARKS}

White pine bark

Powdered white pine bark

\section{CHAPTER V}

WOODS

Cross-section quassia Radial-section quassia . Tangential-section quassia

\section{CHAPTER VI}

\section{LEAVES}

Klip buchu .

Powdered klip buchu

Mountain laurel

Trailing arbutus

\section{CHAPTER VII}

\section{FLOWERS}

\section{Pollen grains}

Non-spiny-walled pollen grains

Spiny-walled pollen grains

Stigma papillæ 
Powdered insect flowers . . . . . . . . . . . . . 278

Open insect flowers . . . . . . . . . . . . . . . 280

Powdered white daisies . . . . . . . . . . . . . . 282

\section{CHAPTER VIII}

FRUITS

Celery fruit . . . . . . . . . . . . . . 285

\section{CHAPTER IX}

\section{SEEDS}

Sweet almonds . . . . . . . . . . . . . . . . 289

\section{CHAPTER X}

\section{ARRANGEMENT OF VASCULAR BUNDLES}

Types of fibro-vascular bundles . . . . . . . . . . . . 292

Radial vascular bundles . . . . . . . . . . . . . 292

Concentric vascular bundles . . . . . . . . . . . . . 295

Collateral vascular bundles . . . . . . . . . . . . 295

Bi-collateral vascular bundles . . . . . . . . . . . 298

Open collateral vascular bundles . . . . . . . . . . . 298 



\section{Part I}

SIMPLE AND COMPOUND MICROSCOPES AND MICROSCOPIC TECHNIC 



\section{CHAPTER I}

\section{THE SIMPLE MICROSCOPES}

The construction and use of the simple microscope (magnifiers) undoubtedly date back to very early times. There is sufficient evidence to prove that spheres of glass were used as burning spheres and as magnifiers by people antedating the Greeks and Romans.

The simple microscopes of to-day have a very wide range of application and a corresponding variation in structure and in appearance.

Simple microscopes are used daily in classifying and studying crude drugs, testing linen and other cloth, repairing watches, in reading, and identifying insects. The more complex simple microscopes are used in the dissection and classification of flowers.

The watchmaker's loupe, the linen tester, the reading glass, the engraver's lens, and the simplest folding magnifiers consist of a double convex lens. Such a lens produces an erect, enlarged image of the object viewed when the lens is placed so that the object is within its focal distance. The focal distance of a lens varies according to the curvature of the lens. The greater the curvature, the shorter the focal distance and the greater the magnification.

The more complicated simple microscope consists of two or more lenses. The double and triple magnifiers consist of two and three lenses respectively.

When an object is viewed through three lenses, the magnification is greater than when viewed through one or two lenses, but a smaller part of the object is magnified. 


\section{FORMS OF SIMPLE MICROSCOPES}

\section{TRIPOD MAGNIFIER}

The tripod magnifier (Fig. I) is a simple lens mounted on a mechanical stand. The tripod is placed over the object and the focus is obtained by means of a screw which raises or lowers the lens, according to the degree it is magnified.

\section{WATCHMAKER'S LOUPE}

The watchmaker's loupe (Fig. 2) is a one-lens magnifier mounted on an ebony or metallic tapering rim, which can be

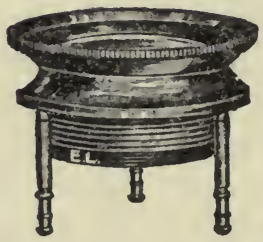

FIG. I.-Tripod Magnifier

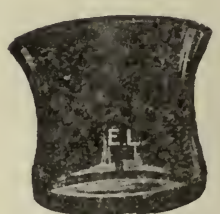

FIG. 2.-Watchmaker's Loupe

placed over the eye and held in position by frowning or contracting the eyelid.

\section{FOLDING MAGNIFIER}

The folding magnifier (Fig. 3 ) of one or more lenses is mounted in such a way that, when not in use, the lenses fold up like the

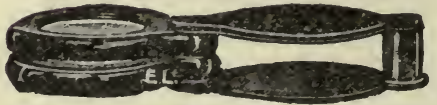

FIG. 3.-Folding Magnifier

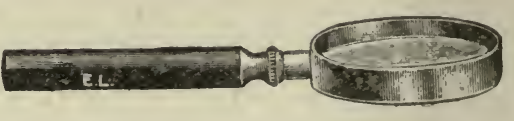

FIG. 4.--Reading Glass

blade of a knife, and when so folded are effectively protected from abrasion by the upper and lower surfaces of the folder.

\section{READING GLASSES}

Reading glasses (Fig. 4) are large simple magnifiers, often six inches in diameter. The lens is encircled with a metal band and provided with a handle. 


\section{STEINHEIL APLANATIC LENSES}

Steinheil aplanatic lenses (Fig. 5) consist of three or four lenses cemented together. The combination is such that the field is large, flat, and achromatic. These lenses are suitable

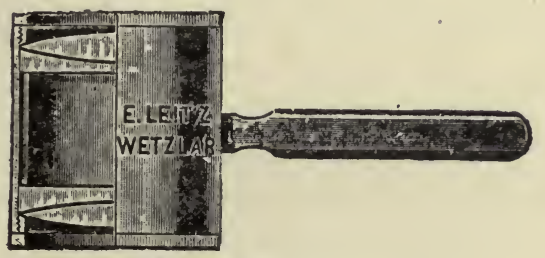

FIG. 5.-Steinheil Aplanatic Lens

for field, dissecting, and pocket use. When such lenses are placed in simple holders, they make good dissecting microscopes.

\section{DISSECTING MICROSCOPE}

The dissecting microscope (Fig. 6) consists of a Steinheil lens and an elaborate stand, a firm base, a pillar, a rack and

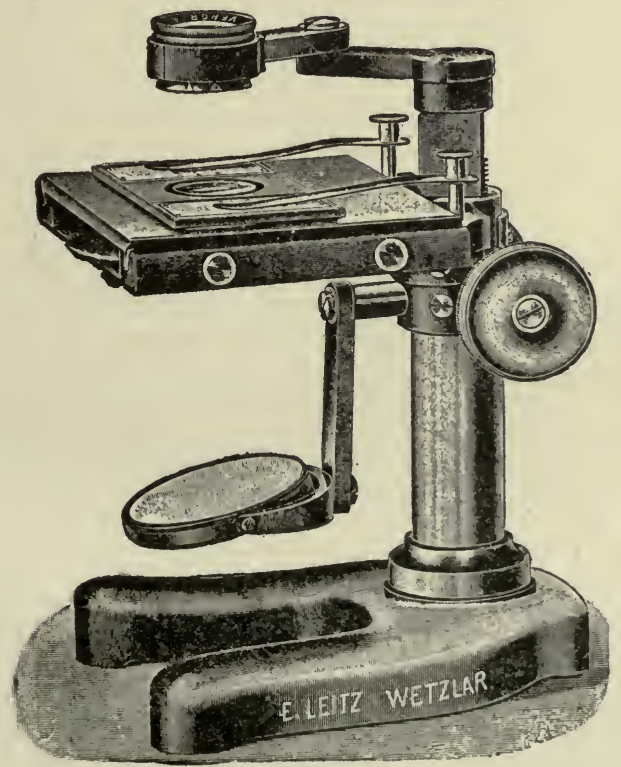

FIG. 6.-Dissecting Microscope 
pinion, a glass stage, beneath which there is a groove for holding a metal plate with one black and one white surface. The nature of the object under observation determines whether a plate is used. When the plate is used and when the object is studied by reflected light it is sometimes desirable to use the black and sometimes the white surface. The mirror, which has a concave and a plain surface, is used to reflect the light on the glass stage when the object is studied by transmitted light. The dissecting microscope magnifies objects up to twenty diameters, or twenty times their real size. 


\section{CHAPTER II \\ COMPOUND MICROSCOPES}

The compound microscope has undergone wonderful changes since 1667 , the days of Robert Hooke. When we consider the crude construction and the limitations of Robert Hooke's microscope, we marvel at the structural perfection and the unlimited possibilities of the modern instrument. The advancement made in most sciences has followed the gradual perfection of this instrument.

The illustration of Robert Hooke's microscope (Fig. 7) will convey to the mind more eloquently than words the crudeness of the early microscopes, especially when it is compared with the present-day microscopes.

\section{STRUCTURE OF THE COMPOUND MICROSCOPE}

The parts of the compound microscope (Fig. 8) may be grouped into-first, the mechanical, and, secondly, into the optical parts.

\section{THE MECHANICAL PARTS}

I. The foot is the basal part, the part which supports all the other mechanical and optical parts. The foot should be heavy enough to balance the other parts when they are inclined. Most modern instruments have a three-parted or tripodshaped base.

2. The pillar is the vertical part of the microscope attached to the base. The pillar is joined to the limb by a hinged joint. The hinges make it possible to incline the microscope at any angle, thus lowering its height. In this way, short, medium, and tall persons can use the microscope with facility. The part of the pillar above the hinge is called the limb. The limb may be either straight or curved. The curved form is preferable, since it offers a more suitable surface to grasp in transferring from box or shelf to the desk, and vice versa. 


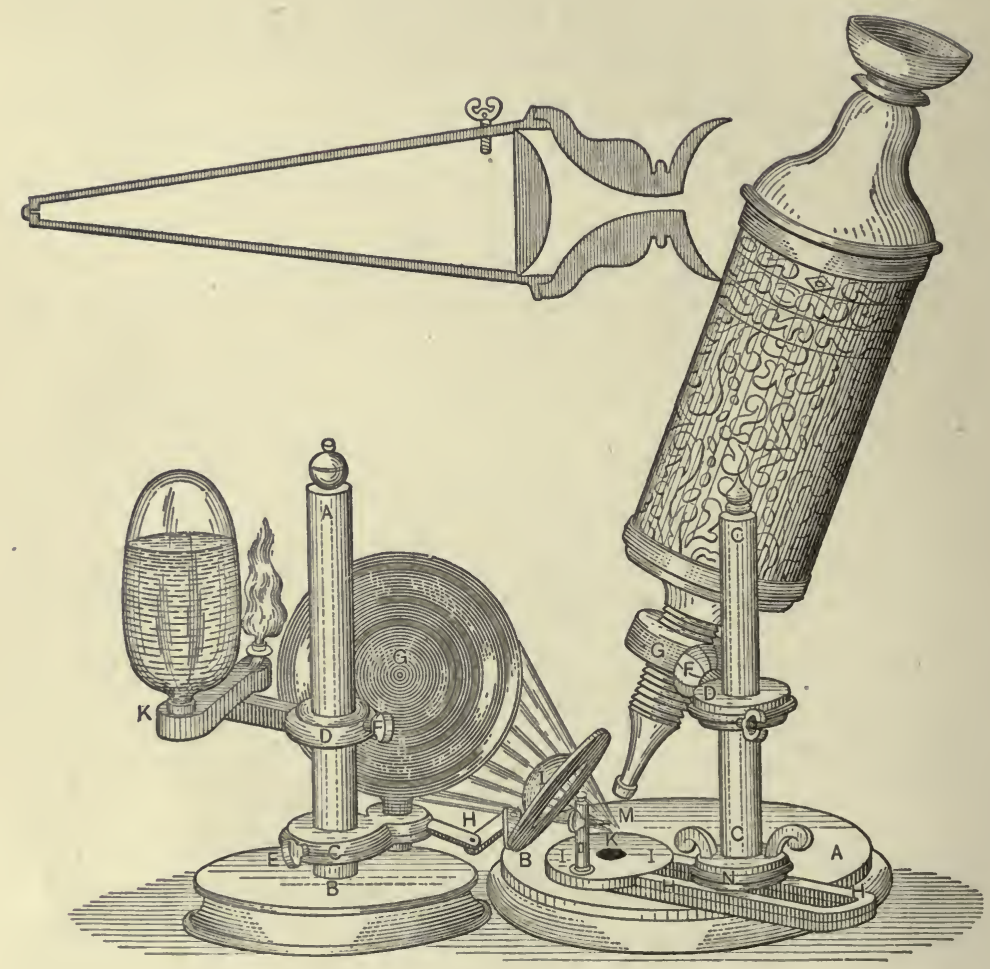

FIG. 7.-Compound Microscope of Robert Hooke 
3. The stage is either stationary or movable, round or square, and is attached to the limb just above the hinge. The upper surface is made of a composition which is not easily attacked by moisture and reagents. The centre of the stage is perforated by a circular opening.

4. The sub-stage is attached below the stage and is for the purpose of holding the iris diaphragm and Abbé condenser. The raising and lowering of the sub-stage are accomplished by a rack and pinion.

5. The iris diaphragm, which is held in the sub-stage below the Abbé condenser, consists of a series of metal plates, so arranged that the light entering the microscope may be cut off completely or its amount regulated by moving a control pin.

6. The fine adjustment is located either at the side or at the top of the limb. It consists of a fine rack and pinion, and is used in focusing an object when the low-power objective is in position, or in finding and focusing the object when the highpower objective is in position.

7. The coarse adjustment is a rack and pinion used in raising and lowering the body-tube and in finding the approximate focus when either the high- or low-power objective is in position.

8. The body-tube is the path traveled by the rays of light entering the objectives and leaving by the eye-piece. To the lower part of the tube is attached the nose-piece, and resting in its upper part is the draw-tube, which holds the eye-piece. On the outer surface of the draw-tube there is a scale which indicates the distance it is drawn from the body-tube.

9. The nose-piece may be simple, double, or triple, and it is protected from dust by a circular piece of metal. Double and triple nose-pieces may be revolved, and like the simple nosepiece they hold the objectives in position.

\section{THE OPTICAL PARTS}

I. The mirror is a sub-stage attachment one surface of which is plain and the other concave. The plain surface is used with an Abbé condenser when the source of light is distant, while the concave surface is used with instruments without an Abbé condenser when the source of light is near at hand. 


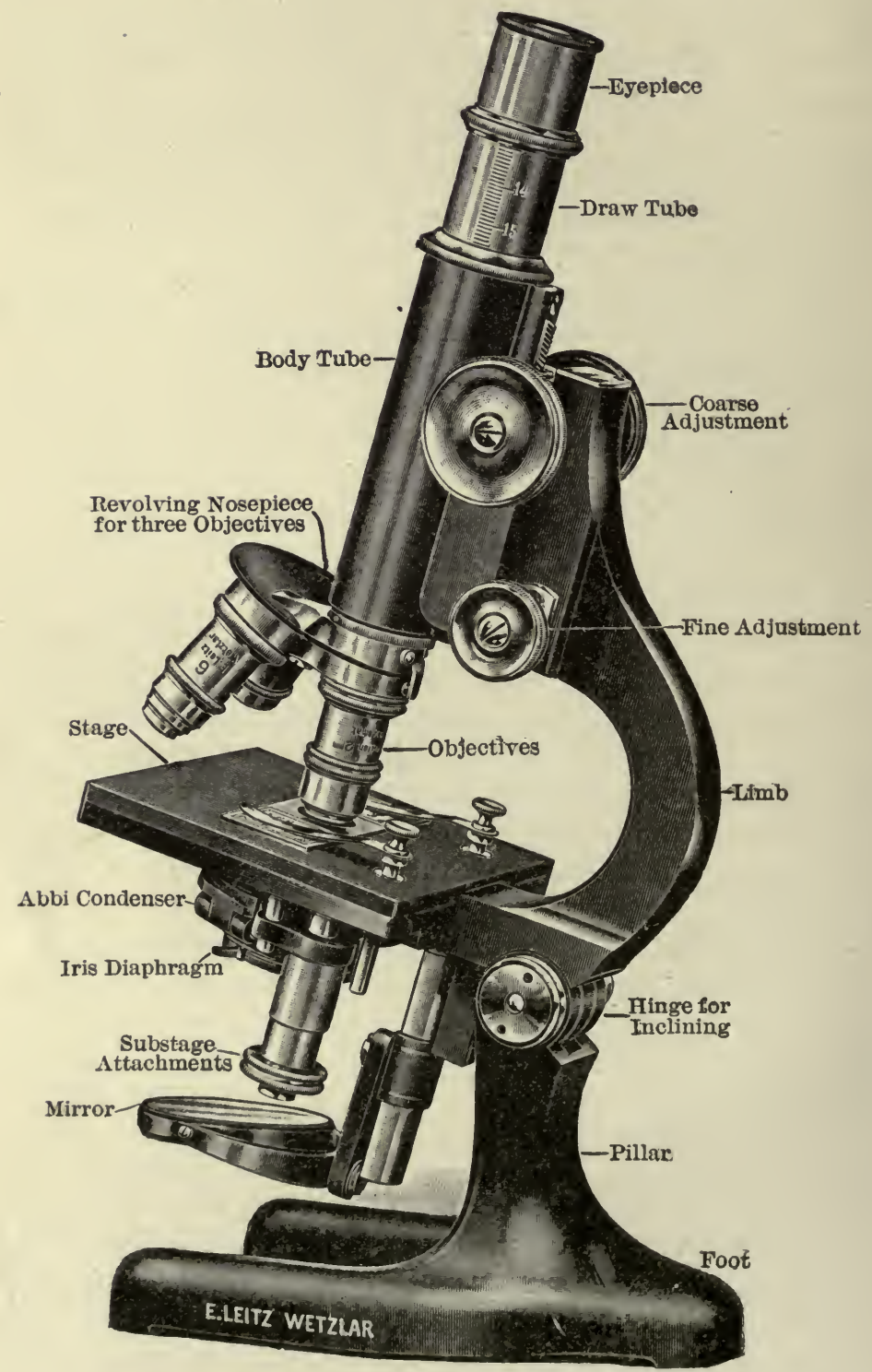

FIG. 8.-Compound Microscope 
2. The Abbé condenser (Fig. 9) is a combination of two or more lenses, arranged so as to concentrate the light on the specimen placed on the stage. The condenser is located in the opening of the stage, and its uppermost surface is circular and flat.

3. Objectives (Figs. IO, II, and I2). There are low, medium, and high-power objectives. The low-power objectives have fewer and larger lenses, and they magnify least, but they show more of the object than do the high-power objectives.

There are three chief types of objectives: First, dry objectives; second, wet

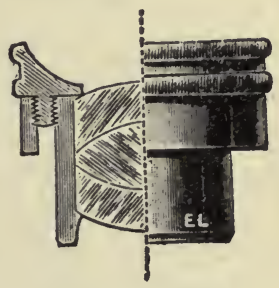

Fig. 9.-Abbé

Condenser objectives, of which there are the water-immersion objectives; and third, the oil-immersion objectives. The dry objectives are used for most histological and pharmacognostical work. For studying smaller objects the water ob-

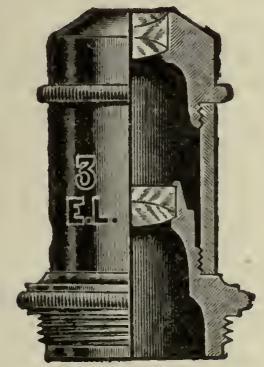

FIG. IO.

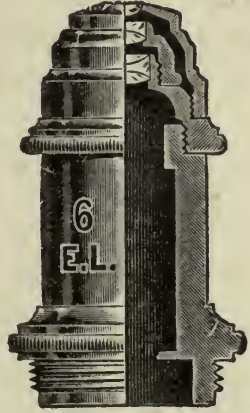

Frg. II.

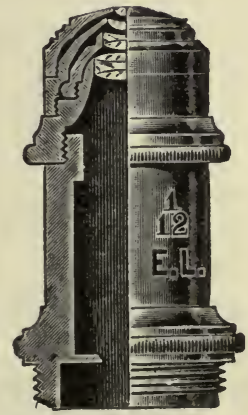

FIG. 12.

Objectives.

jective is sometimes desirable, but in bacteriological work the oil-immersion objective is almost exclusively used. The globule of water or oil, as the case may be, increases the amount of light entering the objective, because the oil and water bend many rays into the objective which would otherwise escape.

4. Eye-pieces (Figs. I3, I4, and I5) are of variable length, but structurally they are somewhat similar. The eye-piece consists of a metal tube with a blackened inner tube. In the 
centre of this tube there is a small diaphragm for holding the ocular micrometer. In the lower end of the tube a lens is fastened by means of a screw. This, the field lens, is the larger lens of the ocular. The upper, smaller lens is fastened in the

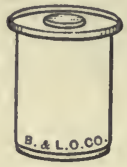

FIG. I3.

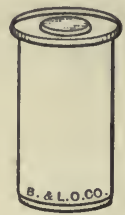

FIG. I4.

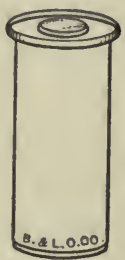

FIG. 15 .

Eye-Pieces.

tube by a screw, but there is a projecting collar which rests, when in position, on the draw-tube.

The longer the tube the lower the magnification. For instance, a two-inch ocular magnifies less than an inch and a half, a one-inch less than a three-fourths of an inch, etc.

The greater the curvature of the

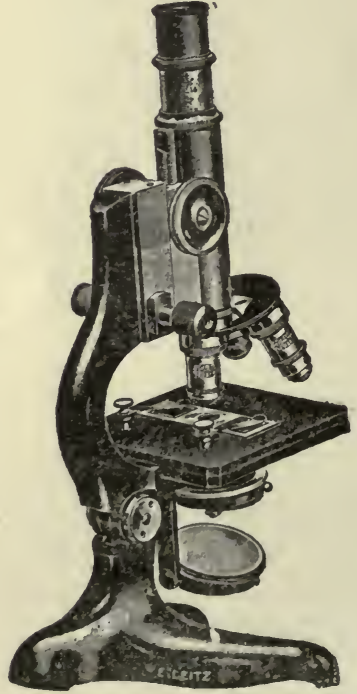

FIG. I6.-Pharmacognostic Microscope lenses of the ocular the higher will be the magnification and the shorter the tube-length.

\section{FORMS OF COMPOUND MICROSCOPES}

The following descriptions refer to three different models of compound microscopes: one which is used chiefly as a pharmacognostic microscope, one as a research microscope stand, while the third type represents a research microscope stand of highest order, which is used at the same time for taking microphotographs.

\section{PHARMACOGNOSTIC MICROSCOPE}

The pharmacognostic microscope (Fig. I6) is an instrument which 
embodies only those parts which are most essential for the examination of powdered drugs, bacteria, and urinary sediments. This microscope is provided with a stage of the dimensions $105 \times 105 \mathrm{~mm}$. This factor and the distance of $80 \mathrm{~mm}$. from the optical centre to the handle arm render it available for the examination of even very large objects and preparations, or preparations suspended in glass dishes. The stand is furnished with a side micrometer, a fine adjustment having knobs on both sides, thereby permitting the manipulation of the micrometer screw either by left or right hand. The illuminating apparatus consists of the Abbé condenser of numerical aperture of 1.20 , to which is attached an iris diaphragm for the proper adjustment of the light. A worm screw, mounted in connection with the condenser, serves for the raising and lowering of the condenser, so that the cone of illuminating pencils can be arranged in accordance to the objective employed and to the preparation under observation. The objectives necessary are those of the achromatic type, possessing a focal length of $16.2 \mathrm{~mm}$. and $3 \mathrm{~mm}$. Oculars which render the best results in regard to magnification in connection with the two objectives mentioned are the Huyghenian eye-pieces II and IV so that magnifications are obtained varying from 62 to 625 . It is advisable, however, to have the microscope equipped with a triple revolving nose-piece for the objectives, so that provision is made for the addition of an oil-immersion objective at any time later should the microscope become available for bacteriological investigations.

\section{THE RESEARCH MICROSCOPE}

The research microscope used in research work (Fig. I 7) must be equipped more elaborately than the microscope especially designed for the use of the pharmacognosist. While the simple form of microscope is supplied with the small type of Abbé condenser, the research microscope is furnished with a large illuminating apparatus of which the iris diaphragm is mounted on a rack and pinion, allowing displacement obliquely to the optical centre, also to increase resolving power in the objectives when observing those objects which cannot be revealed to the best advantage with central illumination. Another iris is 
furnished above the condenser; this iris becomes available the instant an object is to be observed without the aid of the condenser, in which case the upper iris diaphragm allows proper adjustment of the light. The mirror, one side plane, the other concave, is mounted on a movable bar, along which it can be slid-another convenience for the adjustment of the light. The microscope stage of this stand is of the round, rotating

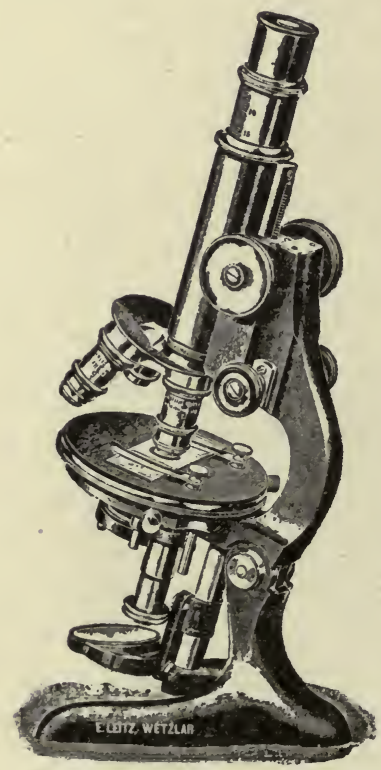

FIG. 17.-Research Microscope

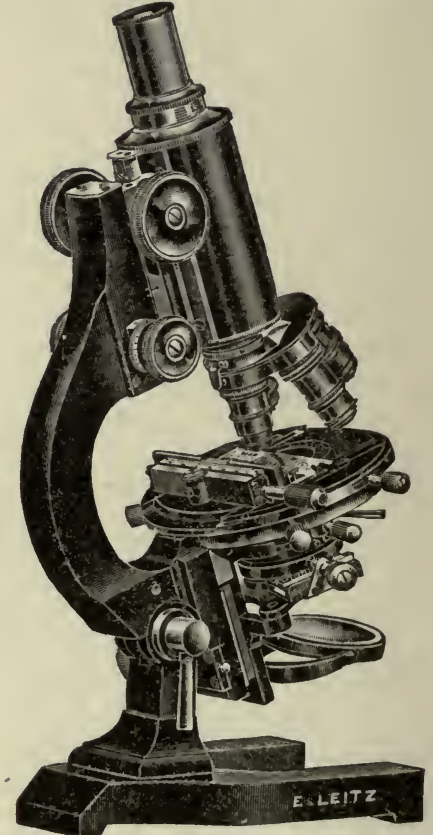

FIG. 18.-Special Research Microscope

and centring pattern, which permits a limited motion to the object slide: The rotation of the microscope stage furnishes another convenience in the examination of objects in polarized light, allowing the preparation to be rotated in order to distinguish the polarization properties of the objects under observation.

\section{SPECLAL RESEARCH MICROSCOPE}

A special research microscope of the highest order (Fig. 18) is supplied with an extra large body tube, which renders it of 
special advantage for micro-photography. Otherwise in its mechanical equipment it resembles very closely the mediumsized research microscope stand, with the exception that the stand is larger in its design, therefore offering universal application. In regard to the illuminating apparatus, it is advisable to mention that the one in the large research microscope stand is furnished. with a three-lens condenser of a numerical aperture of $\mathrm{I} .40$, while the medium-sized research stand is provided with a two-lens condenser of a numerical aperture of I.20. The stage of the microscope is provided with a cross motion-the backward and forward motion of the preparation is secured by rack and pinion, while the side motion is controlled by a micrometric worm screw. In cases where large preparations are to be photographed, the draw-tube with ocular and the slider in which the draw-tubes glide are removed to allow the full aperture of wide-angle objectives to be made use of.

\section{BINOCULAR MICROSCOPE}

The Greenough binocular microscope, as shown in Fig. I9, consists of a microscope stage with two tubes mounted side by side and moving on the same rack and pinion for the focusing adjustment. Either tube can be used without the other. The oculars are capable of more or less separation to suit the eyes of different observers. In each of the drub-like mountings, near the point where the oculars are introduced, porro-prisms

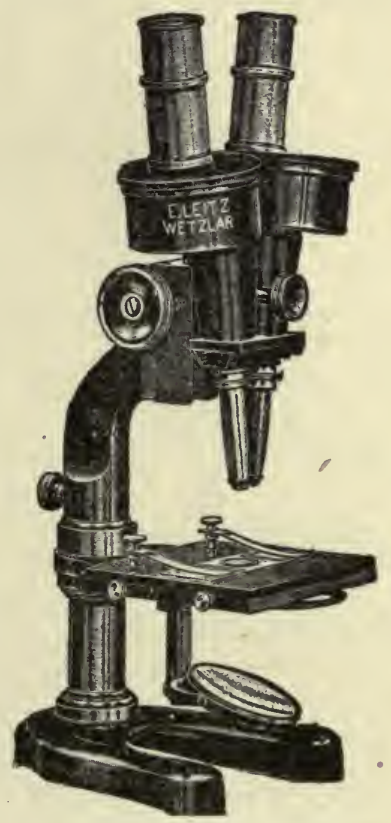

FIG. 19.-Greenough Binocular Microscope have been placed, which erect the image. This microscope gives most perfect stereoscopic images, which are erect instead of inverted, as in the monocular compound microscopes. The Greenough binocular microscope is especially adapted for dissection and for studying objects of considerable thickness. 


\section{POLARIZATION MICROSCOPE}

The polarization microscope (Fig. 20) is used chiefly for the examination of crystals and mineral sections as well as for the observation of organic bodies in polarized light. It can, however, also be used for the examination of regular biological preparations.

If compared with the regular biological microscope, the polarization microscope is found characteristic of the following points: it is supplied with a polarization arrangement. The latter consists of a polarizer and analyzer. The polarizer is situated in a rotating mount beneath the condensing system.

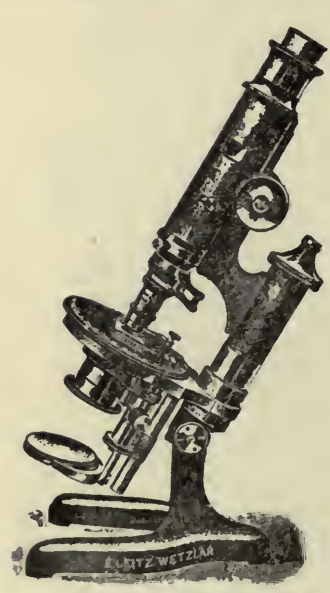

FIG. 20.-Polarization Microscope The microscope, of which the diagram is shown, possesses a triple "Ahrens" prism of calcite. The entering light is divided into two polarized parts, situated perpendicularly to each other. The so-called "ordinary" rays are reflected to one side by total reflection, which takes place on the inner cemented surface of the triple prism, allowing the so-called "extraordinary" rays to pass through the condenser. If the prism is adjusted to its focal point, it is so situated that the vibration plane of the extra-ordinary rays are in the same position as shown in the diagram of the illustration.

The analyzer is mounted within the microscope-tube above the objective. Situated on a sliding plate, it can be shifted into the optical axis whenever necessary. The analyzer consists of a polarization prism after Glan-Thompson. The polarization plane of the active extraordinary rays is situated perpendicularly to the plane as shown in the diagram. The polarization prisms are ordinarily crossed. In this position the field of the microscope is darkened as long as no substance of a double refractive index has been introduced between the analyzer and polarizer. In rotating the polarizer up to the mark 90 , the polarization prisms are mounted parallel and the field of the 
microscope is lighted again. Immediately above the analyzer and attached to the mounting of the analyzer a lens of a comparatively long focal length has been placed in order to overcome the difference in focus created by the introduction of the analyzer into the optical rays.

The condensing system is mounted on a slider, and, furthermore, can be raised and lowered along the optical centre by means of a rack-and-pinion adjustment. If lowered sufficiently, the condensing system can be thrown to the side to be removed from the optical rays. The condenser consists of three lenses. The two upper lenses are separately mounted to an arm, which permits them to be tilted to one side in order to be removed from the optical rays. The complete condenser is used only in connection with high-power objectives. As far as low-power objectives are concerned, the lower condensing lens alone is made use of, and the latter is found mounted to the polarizer sleeve. Below the polarizer and above the lower condensing lens an iris diaphragm is found.

The microscope table is graduated on its periphery, and, furthermore, carries a vernier for more exact reading.

The polarization microscope is not furnished with an objective nose-piece. Every objective, however, is supplied with an individual centring head, which permits the objective to be attached to an objective clutch-changer, situated at the lower end of the microscope-tube. The centring head permits the objectives to be perfectly centred and to remain centred even if another objective is introduced into the objective clutch-changer.

At an angle of 45 degrees to the polarization plane of polarizer and analyzer, a slot has been provided, which serves for the introduction of compensators.

Between analyzer and ocular, another slot is found which permits the Amici-Bertrand lens to be introduced into the optical axis. The slider for the Bertrand lens is supplied with two centring screws whereby this lens can be perfectly and easily centred. The Bertrand lens serves the purpose of . observing the back focal plane of the microscope objective. In order to allow the Bertrand lens to be focused, the tube can be raised and lowered for this purpose. An iris diaphragm is mounted above the Bertrand lens. 
If the Bertrand lens is shifted out of the optical axis, one can observe the preparation placed upon the microscope stage and, depending on its thickness or its double refraction, the interference color of the specimen. This interference figure is called the orthoscopic image and, accordingly, one speaks of the microscope as being used as an "orthoscope."

After the Bertrand lens has been introduced into the optical axis, the interference figure is visible in the back focal plane of the objective. Each point of this interference figure corresponds to a certain direction of the rays of the preparation itself. This arrangement permits observation of the change of the reflection of light taking place in the preparation, this in accordance with the change of the direction of the rays. This interference figure is called the conoscopic image, and, accordingly, the microscope is used as a "conoscope."

Many types of polarization microscopes have been constructed; those of a more elaborate form are used for research investigations; others of smaller design for routine investigations. 


\section{CHAPTER III}

\section{MICROSCOPIC MEASUREMENTS}

In making critical examinations of powdered drugs, it is frequently necessary to measure the elements under observation, particularly in the case of starches and crystals.

\section{OCULAR MICROMETER}

Microscopic measurements are made by the ocular micrometer (Fig. 2I). This consists of a circular piece of transparent glass on the centre of which is etched a one- or two-millimeter scale divided into one hundred or two hundred divisions re-

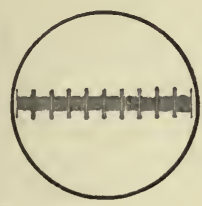

FIG. 21.-Ocular Micrometer

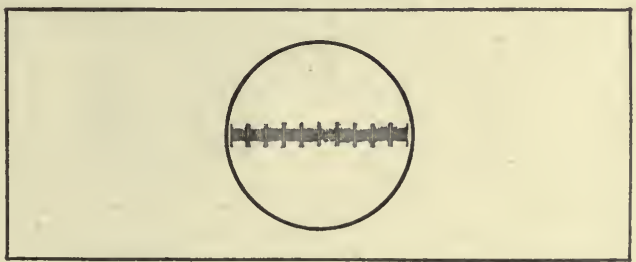

FIG. 22.-Stage Micrometer

spectively. The value of each line is determined by standardizing with a stage micrometer.

\section{STAGE MICROMETER}

The -stage micrometer (Fig. 22) consists of a glass slide upon which is etched a millimeter scale divided into one hundred equal parts or lines: each line has a value of one hundredth of a millimeter.

STANDARDIZATION OF OCULAR MICROMETER WITH LOW-POWER OBJECTIVE

Having placed the ocular micrometer in the eye-piece and the stage micrometer on the centre of the stage, focus until 
the lines of the stage micrometer are clearly seen. Then adjust the scales until the lines of the stage micrometer are parallel with and directly under the lines of the ocular micrometer.

Ascertain the number of lines of the stage micrometer covered by the one hundred lines of the ocular micrometer. Then calculate the value of each line of the ocular. This is done in the following manner:

If the one hundred lines of the ocular cover seventy-five lines of the stage micrometer, then the one hundred lines of the ocular micrometer are equivalent to seventy-five onehundredths, or three-fourths, of a millimeter. One line of the ocular micrometer will therefore be equivalent to one-hundredth

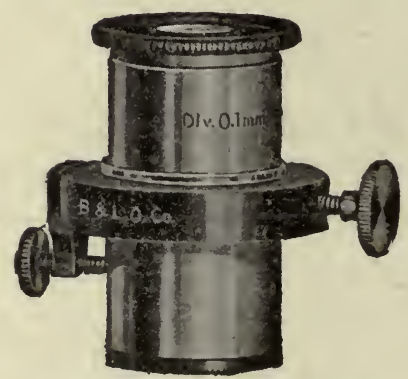

FIG. 23.-Micrometer Eye-Piece

of seventy-five one-hundredths, or .0075 part of a millimeter, and as a micron is the unit for measuring microscopic objects, this being equivalent to one one-thousandth of a millimeter, the value of each line of the ocular will therefore be 7.5 microns.

With the high-power objective in place, ascertain the value of each line of the ocular. If one hundred lines of the ocular cover only twelve lines of the stage micrometer, then the one hundred lines of the ocular are equivalent to twelve one-hundredths of a millimeter, the value of one line being equivalent to one one-hundredth of twelve one-hundredths, or twelve tenthousandths of a millimeter, or .0012, or $1.2 u$.

It will therefore be seen that objects as small as a thousandth of a millimeter can be accurately measured by the ocular micrometer.

In making microscopic measurements it is only necessary 
to find how many lines of the ocular scale are covered by the object. The number of lines multiplied by the equivalent of each line will be the size of the object in microns, or micromillimeters.

\section{MICROMETER EYE-PIECES}

Micrometer eye-pieces (Figs. 23 and 24) may be used in making measurements. These eye-pieces with micrometer com-

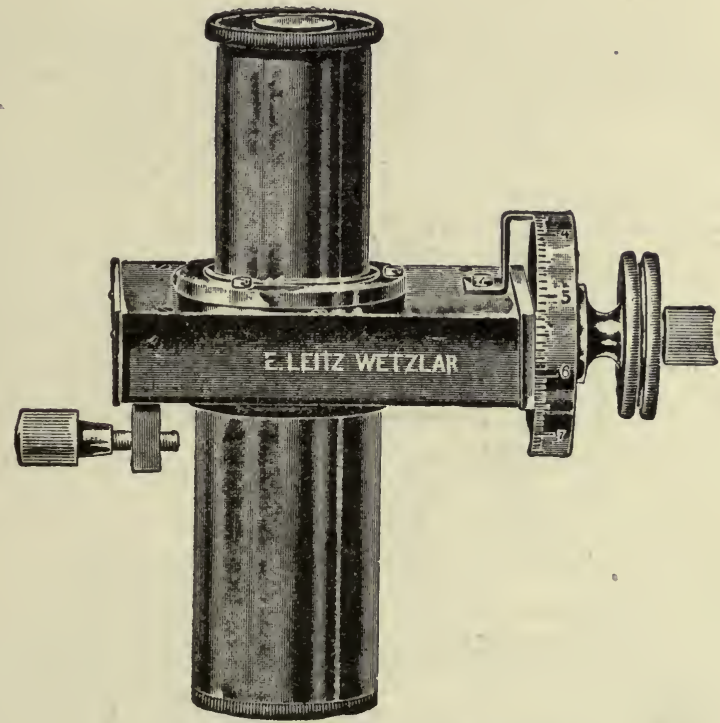

FIG. 24.-Micrometer Eye-Piece

binations are preferred by some workers, but the ocular micrometer will meet the needs of the average worker.

\section{MECHANICAL STAGES}

Moving objects by hand is tiresome and unsatisfactory, first, because of the possibility of losing sight of the object under observation, and secondly, because the field cannot be covered so systematically as when a mechanical stage is used for moving slides.

The mechanical stage (Fig. 25) is fastened to the stage by a screw. The slide is held by two clamps. There is a rack and 
pinion for-moving the slide to left or right, and another rack and pinion for moving the slide forward and backward.

\section{CAMERA LUCIDA}

The camera lucida is an optical mechanical device for aiding the worker in making drawings of microscopic objects. The

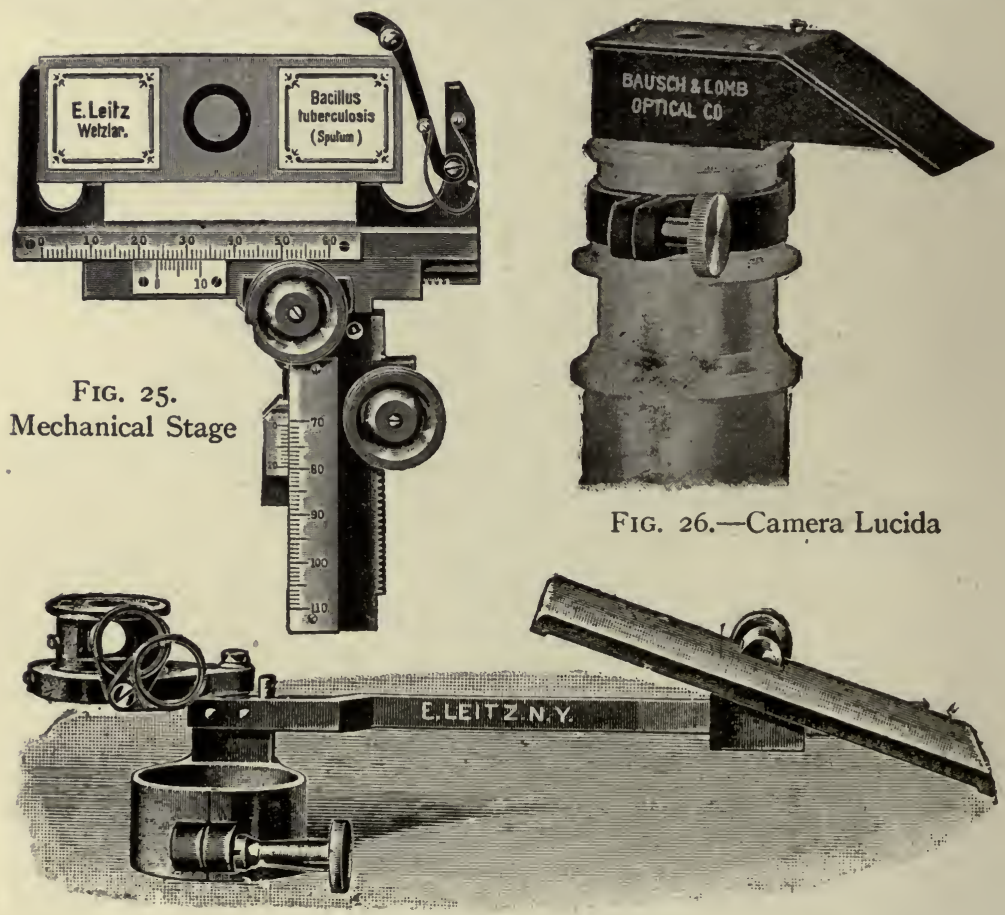

FIG. 27.-Camera Lucicia

instrument is particularly necessary in research work where it is desirable to reproduce an object in all its details. In fact, all reproductions illustrating original work should be made by means of the camera lucida or by microphotography.

A great many different types of camera lucidas or drawing apparatus are obtainable, varying from simple-inexpensive to complex-expensive forms. Figs. 26, 27, and 28 show simple and complex forms. 


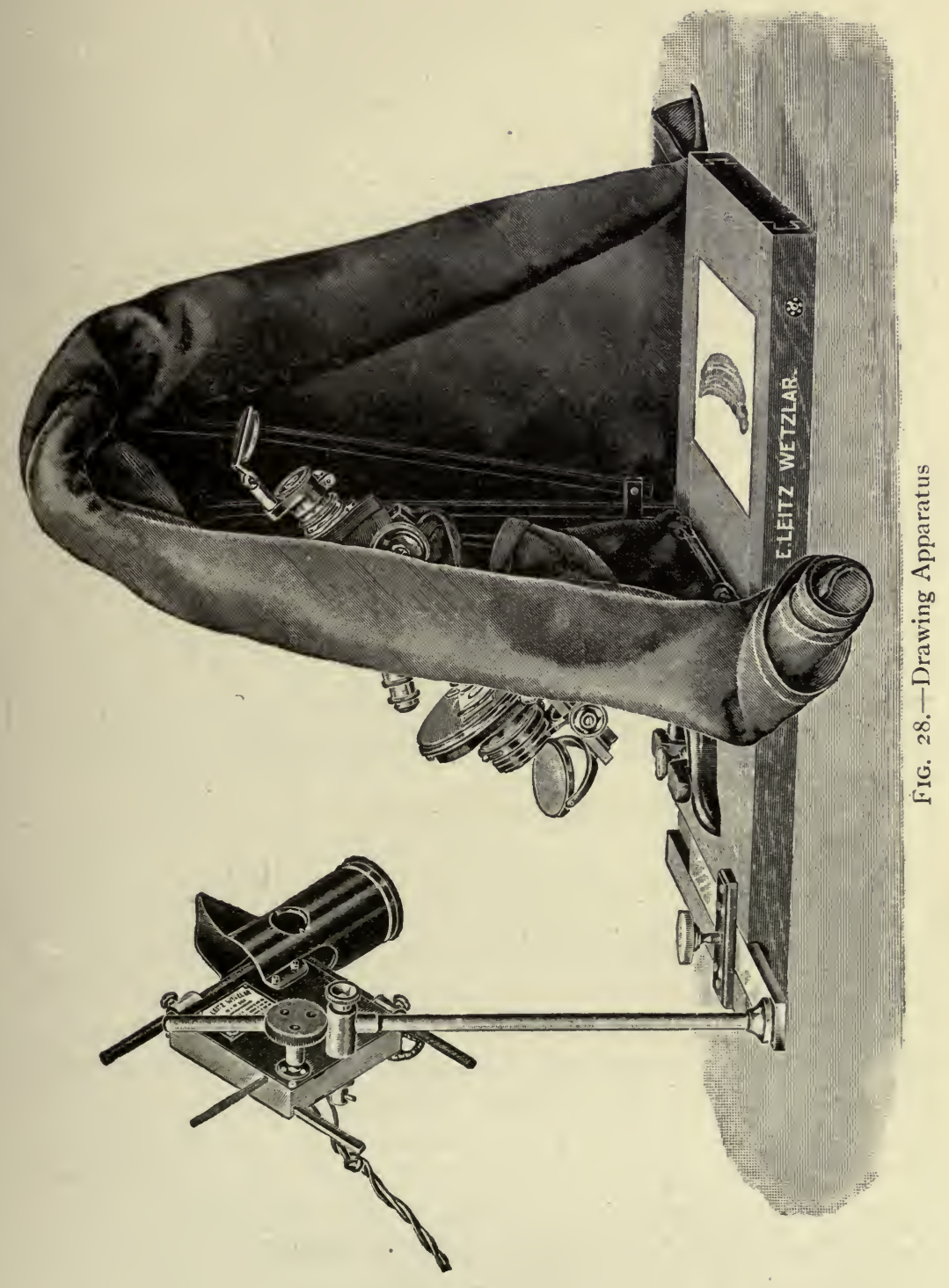




\section{MICROPHOTOGRAPHIC APPARATUS}

The microphotographic apparatus (Fig. 29), as the name implies, is an apparatus constructed in such a manner that it may be attached to a microscope when we desire to photograph microscopic objects. It consists of a metal base and a polished metal pillar for holding the bellows, slide holder, ground-glass observation plate, and eye-piece. In making photographs, the small end of the bellows is attached to the ocular of the micro-

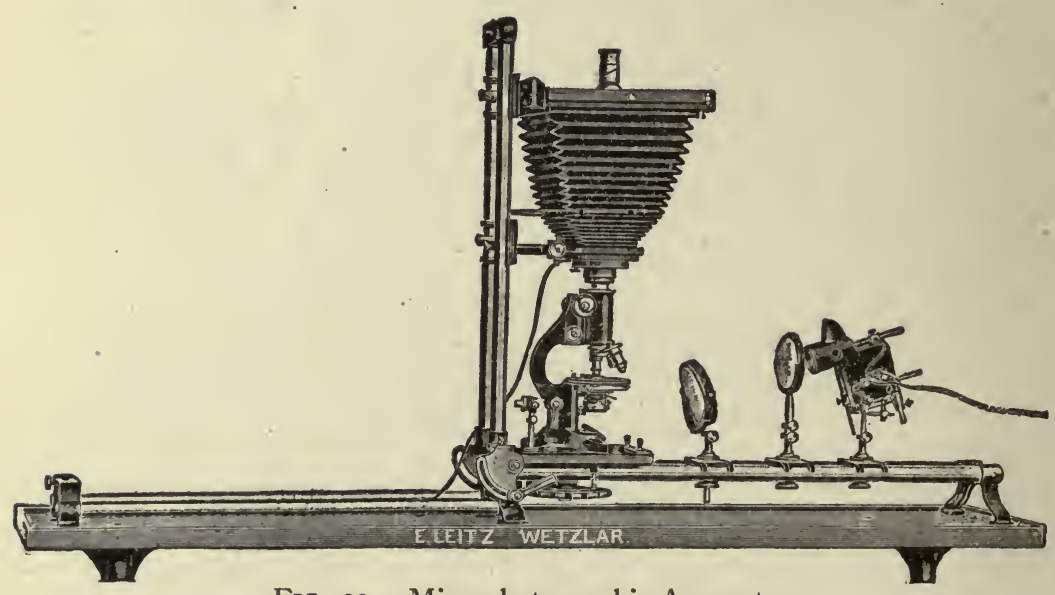

FIG. 29.-Microphotographic Apparatus

scope, the tocus adjusted, and the object or objects photographed. More uniform results are obtained in making such photographs if an artificial light of an unvarying candle-power is used.

There are obtainable more elaborate microphotographic apparatus than the one figured and described, but for most workers this one will prove highly satisfactory. It is possible, by inclining the tube of the microscope, to make good microphotographs with an ordinary plate camera. This is accomplished by removing the lens of the camera and attaching the bellows to the ocular, focusing, and photographing. 


\section{CHAPTER IV}

\section{HOW TO USE THE MICROSCOPE}

In beginning work with the compound microscope, place the base of the microscope opposite your right shoulder, if you are right-handed; or opposite your left shoulder, if you are lefthanded. Incline the body so that the ocular is on a level with your eye, if necessary; but if not, work with the body of the microscope in an erect position. In viewing the specimen, keep both eyes open. Use one eye for observation and the other for sketching. In this way it will not be necessary to remove the observation eye from the ocular unless it be to complete the details of a sketch.

Learn to use both eyes. Most workers, however, accustom themselves to using one eye; when they are sketching, they use both eyes, although it is not necessary to do so.

Open the iris diaphragm, and incline the mirror so that white light is reflected on the Abbé condenser. Place the slide on the centre of the stage, and if the slide contains a section of a plant, move the slide so as to place this specimen over the centre of the Abbé condenser. Then lower the body by means of the coarse adjustment until the low-power object, which should always be in position when work is begun, is within onefourth of an inch of the stage. Then raise the body by means of the coarse adjustment until the object, or objects, in case a powder is being examined, is seen. Open and close the iris diaphragm, finally adjusting the opening so that the best possible illumination is obtained for bringing out clearly the structure of the object or objects viewed. Then regulate the focus by moving the body up or down by turning the fine adjustment. When studying cross-sections or large particles of powders, it is sometimes desirable to make low-power sketches of the specimen. In most cases, however, only sufficient time should be spent in studying the specimen to give an idea of the size, struc- 
ture, and general arrangement or plan or structure if a section of a plant, or, if a powder, to note its striking characters. All the finer details of structure are best brought out with the high-power objective in position.

In placing the high-power objective in position, it is first necessary to raise the body by the coarse adjustment; then open the iris diaphragm, and lower the body until the objective is within about one-eighth of an inch of the slide. Now raise the tube by the fine adjustment until the object is in focus, then gradually close the iris diaphragm until a clear definition of the object is obtained. Now proceed to make an accurate sketch of the object or objects being studied.

In using the water or oil-immersion objectives it is first necessary to place a drop of distilled water or oil, as the case may be, immediately over the specimen, then lower the body by the coarse adjustment until the lens of the objective touches the water or the oil. Raise the tube, regulate the light by the iris diaphragm, and proceed as if the high-power objectives were in position.

The water or oil should be removed from the obiectives and from the slide when not in use.

After the higher-powered objective has been used, the body should be raised, and the low-power objective placed in position. If the draw-tube has been drawn out during the examination of the object, replace it, but be sure to hold one hand on the nose-piece so as to prevent scratching the objective and Abbé condenser by their coming in forceful contact. Lastly, clean the mirror with a soft piece of linen. In returning the microscope to its case, or to the shelf, grasp the limb, or the pillar, firmly and carry as nearly vertical as possible in order not to dislodge the eye-piece.

\section{ILLUMINATION}

The illumination for microscopic work may be from natural or artificial sources.

It has been generally supposed that the best possible illumination for microscopic work is diffused sunlight obtained from a northern direction. No matter from what direction diffused 
sunlight is obtained, it will be found suitable for microscopic work. In no case should direct sunlight be used, because it will be found blinding in its effects upon the eyes. Natural illumination-diffused. sunlight-varies so greatly during the different months of the year, and even during different periods of the day, that individual workers are resorting more and more to artificial illumination. The particular advantage of such illumination is due to the fact that its quality and intensity are uniform at all times. There are many ways of securing such artificial illumination, no one of which has any particular advantage over the other. Some workers use an ordinary gas or electric light with a color screen placed in the sub-stage below the iris diaphragm. In other cases a globe filled with a weak solution of copper sulphate is placed in such a way between the source of light and the microscope that the light is

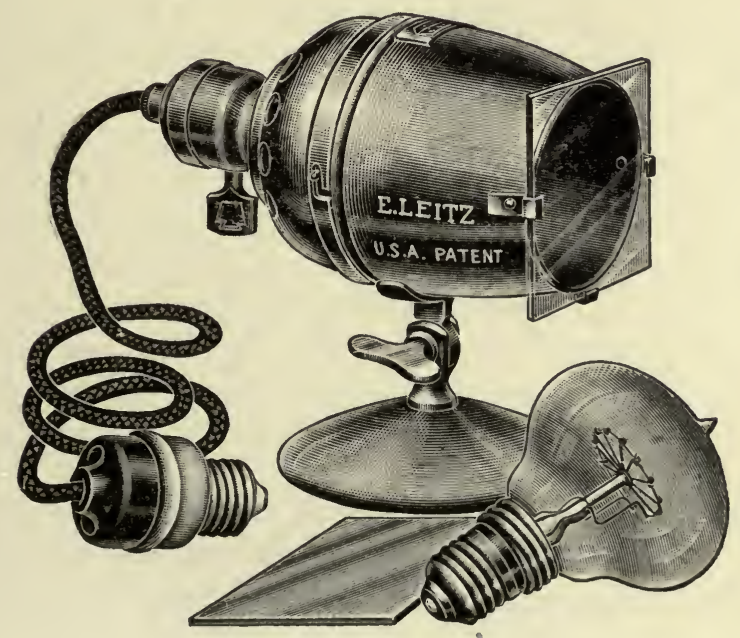

FIG. 30.-Micro Lamp

focused on the mirror. Modern mechanical ingenuity has devised, however, a number of more convenient micro lamps (Fig. 30). These lamps are a combination of light and screen. In some forms a number of different screens come with each lamp, so that it is possible to obtain white-, blue-, or dark-ground 
illumination. The type of the screen used will be varied according to the nature of the object studied.

\section{CARE OF THE MICROSCOPE}

If possible, the microscope should be stored in a room of the same temperature as that in which it is to be used. In any case, avoid storing in a room that is cooler than the place of use, because when it is brought into a warmer room, moisture will condense on the ocular objectives and mirrors.

Before beginning work remove all moisture, dust, etc., from the inner and outer lenses of the ocular, the objectives, the Abbé condenser, and the mirror by means of a piece of soft, old linen. When the work is finished the optical parts should be thoroughly cleaned.

If reagents have been used, be sure that none has got on the objectives or the Abbé condenser. If any reagent has got on these parts, wash it off with water, and then dry them thoroughly with soft linen.

The inner lenses of the eye-pieces and the under lens of the Abbé condenser should occasionally be cleaned. The mechanical parts of the stand should be cleaned if dust accumulates, and the movable surfaces should be oiled occasionally. Never attempt to make new combinations of the ocular or objective lenses, or transfer the objectives or ocular from one microscope to another, because the lenses of any given microscope form a perfect lens system, and this would not be the case if they were transferred. Keep clean cloths in a dust-proof box. Under no circumstances touch any of the optical parts with your fingers.

\section{PREPARATION OF SPECIMENS FOR CUTTING}

Most drug plants are supplied to pharmacists in a dried condition. It is necessary, therefore, to boil the drug in water, the time varying from a few minutes, in the case of thin leaves and herbs, up to a half hour if the drug is a thick root or woody stem. If a green (undried) drug is under examination, this first step is not necessary.

If the specimen to be cut is a leaf, a flower-petal, or other 
thin, flexible part of a plant, it may be placed between pieces of elder pith or slices of carrot or potato before cutting.

\section{SHORT PARAFFIN PROCESS}

In most cases, however, more perfect sections will be obtained if the specimens are embedded in paraffin, by the quick paraffin process, which is easily carried out.

After boiling the specimen in water, remove the excess of moisture from the outer surface with filter paper or wait until the water has evaporated. Next make a mould of stiff cardboard and pour melted paraffin (melting at 50 or 60 degrees) into the mould to a height of about one-half inch, when the paraffin has solidified. This may be hastened by floating it on cool or iced water instead of allowing it to cool at room temperature.

The specimens to be cut are now placed on the paraffin, with glue, if necessary, to hold them in position, and melted paraffin poured over the specimens until they are covered to a depth of about one-fourth of an inch. Cool on iced water, trim off the outer paraffin to the desired depth, and the specimen will be in a condition suitable for cutting.

Good workable sections may be cut from specimens embedded by this quick paraffin method. After a little practice the entire process can be carried out in less than an hour. This method of preparing specimens for cutting will meet every need of the pharmacognosist.

\section{LONG PARAFFIN PROCESS}

In order to bring out the structure of the protoplast (living part of the cell), it will be necessary to begin with the living part of the plant and to use the long paraffin method or the collodion method.

Small fragments of a leaf, stem, or root-tip are placed in chromic-acid solution, acetic alcohol, picric acid, chromacetic acid, alcohol, etc., depending upon the nature of the specimen under observation. The object of placing the living specimen in such solutions is to kill the protoplast suddenly so that the parts of the cell will bear the same relationship to each other 
that they did in the living plant, and to fix the parts so killed.

After the fixing process is complete, the specimen is freed of the fixing agent by washing in water. From the water-bath the specimens are transferred successively to $10,20,40,60,70$, 80,90 , and finally roo per cent alcohol. In this roo per cent alcohol-bath the last traces of moisture are removed. The

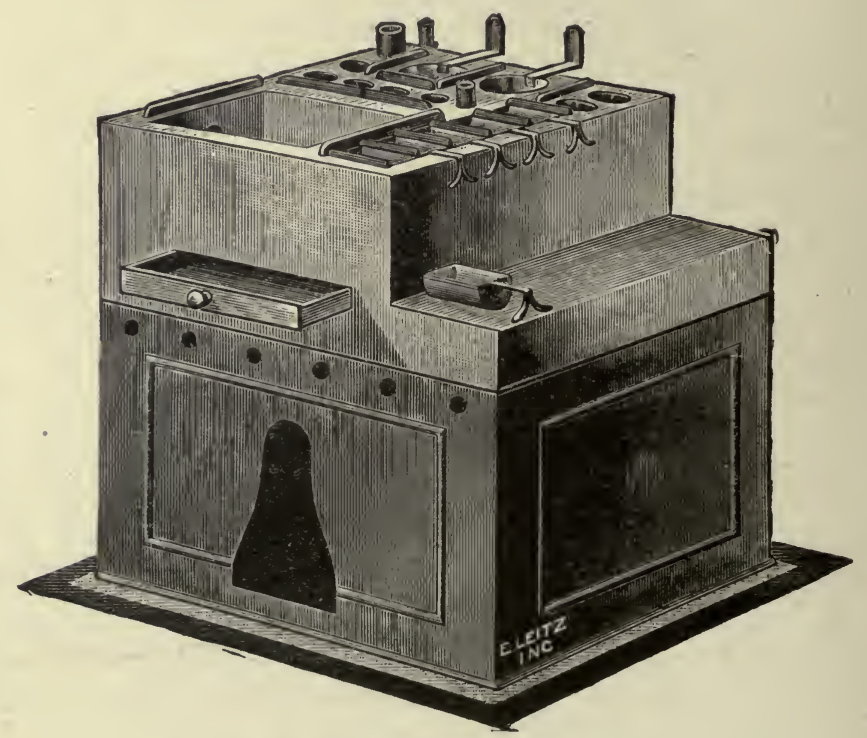

FIG. 31.-Paraffin-embedding Oven

length of time required to leave the specimens in the different percentages of alcohols varies from a. few minutes to twentyfour hours, depending upon the size and the nature of the specimen.

After dehydration the specimen is placed in a clearing agent - chloroform or xylol-both of which are suitable when embedding in paraffin. The clearing agents replace the alcohol in the cells, and at the same time render the tissues transparent. From the clearing agent the specimen is placed in a weak solution of paraffin, dissolved xylol, or chloroform. The strength of the paraffin solution is gradually increased until it consists of pure paraffin. The temperature of the paraffin-embedding 
oven (Fig. 3I) should not be much higher than the meltingpoint of the paraffin.

The specimen is now ready to be embedded. First make a mould of cardboard or a lead-embedding frame (Fig. 32), melt the paraffin, and then place the specimen in a manner that will facilitate cutting. Remove the excess of paraffin and cut when desired.

In using the collodion method for embedding fibrous specimens, as wood, bark, roots, etc.,

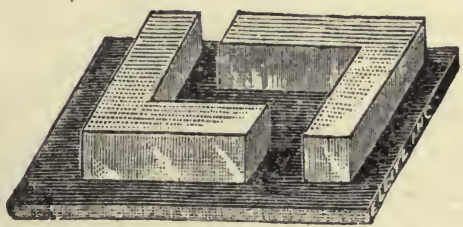

FiG. 32.-Paraffin Blocks the specimen is first fixed with picric acid, washed with water.

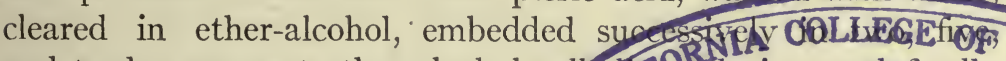
and twelve per cent ether-alcohol confropsolution, andyinally embedded in a pure collodion

\section{CUTTING}

DEPARTMENT

Specimens prepared as descria above mav be cut MEDICA hand microtome or a machine microtes

\section{HAND MICROTOME}

In cutting sections by a hand mierotome, it is necessary to place the specimen, embedded in paraffin or held between pieces of elder pith, carrot, or potato, over the second joints of the fingers, then press the first joints firmly upon the specimen with the thumb pressed against it. If they are correctly

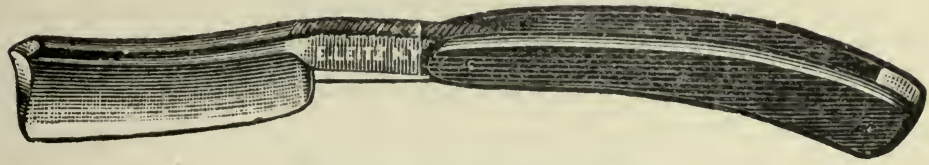

FIG. 33.- Hand Microtome

held, the specimens will be just above the level of the finger and the end of the thumb, and the joint will be below the level of the finger.

Hold the section cutter (Fig. 33) firmly in the hand with 
the flat surface next to the specimen. While cutting the section, press your arm firmly against your chest, and bend the wrist nearly at right angles to the arm. Push the cutting edge of the microtome toward the body and through the specimen in such a way as to secure as thin a section as possible. Do not expect to obtain nice, thin sections during the first or second trials, but-continued practice will enable one to become quite efficient in cutting sections in this manner.

When the examination of drugs is a daily occurrence, the above method will be found highly satisfactory.

\section{MACHINE MICROTOMES}

When a number of sections are to be prepared from a given specimen, it is desirable to cut the sections on a machine microtome, particularly when the sections are to be prepared for the use of students, in which case they should be as uniform as possible.

Great care should be exercised in cutting sections with a machine microtome-first, in the selection of the type of the microtome; and secondly, in the style of knife used in cutting.

For soft tissues embedded in paraffin or collodion, the rotary microtome with vertical knife will give best results. The thickness of the specimen is regulated by mechanical means, so that in cutting the sections it is only necessary to turn a crank and remove the specimens from the knife-edge, unless there is a ribbon-carrier attachment. If the sections are being cut from a specimen embedded by the quick paraffin method, it is best to drop the section in a metal cup partly filled with warm water. This will cause the paraffin to straighten out, and the specimen will uncoil. After sufficient specimens have been cut, the cup should be placed in a boiling-water bath until the paraffin surrounding the sections melts and floats on the water. Before removing the specimen from the water-bath, it is advisable to shake the glass vigorously in order to cause as many specimens as possible to settle to the bottom of the cup. The cup is then placed in iced water or set aside until the paraffin has solidified. The cake-like mass is then removed from the cup, and the sections adhering to its under surface are removed by lifting them carefully off with the flat side of the knife and transferring them, 
together with the sections at the bottom of the cup, to a widemouth bottle, and covered with alcohol, glycerine, and water mixture; or if it is desired to stain the specimens, they should be placed in a weak alcoholic solution.

Specimens having a hard, woody texture should be cut on a sliding microtome by means of a special wood knife, which is especially tempered to cut woody substances. Woody roots, wood, or thick bark may be cut readily on this microtome when they have been embedded by the quick paraffin process. The knife in the sliding microtome is placed in a horizontal position, slanting so that the knife-edge is drawn gradually across the specimen. After cutting, the sections are treated as described above.

The thickness of the sections is regulated by mechanical means. After a section has been cut, the block containing the specimen is raised by turning a thumb-screw. In this microtome the knife, as in the rotary type, is fixed, and the block containing the specimen is movable.

If the specimen has been infiltrated with, and embedded in, paraffin or collodion, the treatment of the sections after cutting should be different.

In the case of paraffin, the sections are fastened directly to the slide, and the paraffin is dissolved by either chloroform or xylol. The specimen is then placed in 100, 95, and 45 per cent alcohol, and then washed in water. These sections are now stained with water-stains, brought back through alcohol, cleared, and mounted in Canada balsam.

If alcoholic stains are used, it will not be necessary to dehydrate before staining, and the dehydration after staining will also be eliminated.

Sections infiltrated with collodion are either stained directly without removing the collodion or after removal.

\section{FORMS OF MICROTOMES}

The hand cylinder microtome (Fig. 34) consists of a cylindrical body. The clamp for holding the specimen is near the top below the cutting surface. At the lower end is attached a micrometer screw with a divided milled head. When moved forward one division, the specimen is raised $0.0 \mathrm{I} \mathrm{mm}$. This micrometer 
screw has an upward movement of $10 \mathrm{~mm}$. The cutting surface consists of a cylindrical glass ring.

The hand table microtome (Fig. 35) is provided with a clamp, by which it may be attached to the edge of a table or desk.

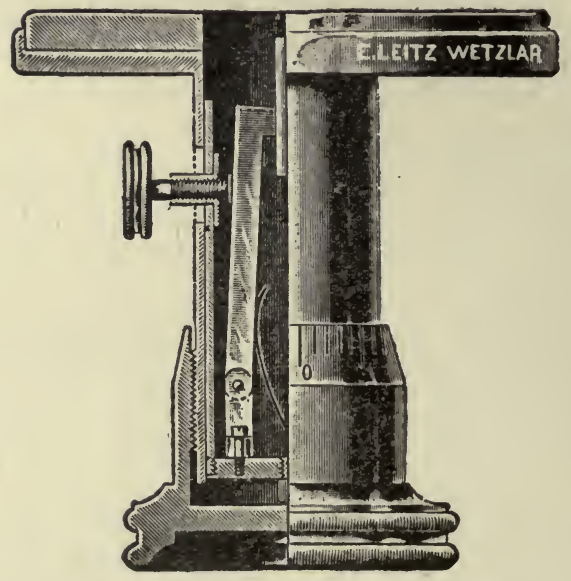

FIG. 34.-Hand Cylinder Microtome

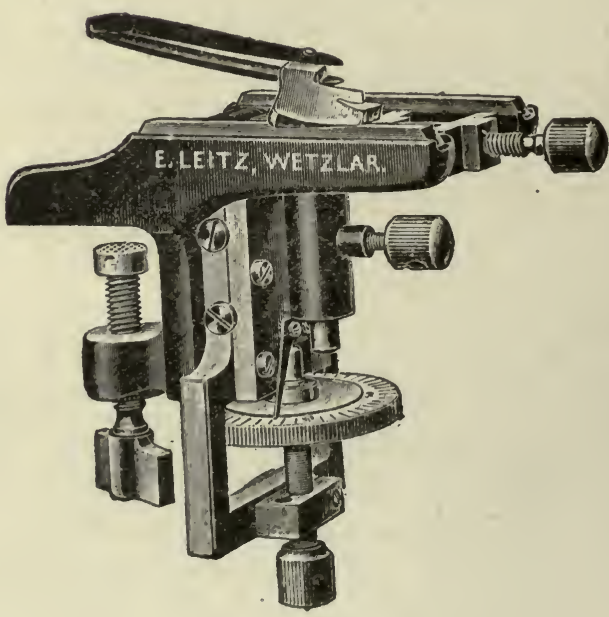

FIG. 35.-Hand Table Microtome 
The cutting surface consists of two separated but parallel glass benches. The object is held by a clamp and is raised by a micrometer screw, which, when moved through one division by turning the divided head, raises the specimen $0.0 \mathrm{Imm}$.

The sliding microtome has a track of $250 \mathrm{~mm}$. The object is held by a clamp and its height regulated by hand. The disk regulating the micrometer screw is divided into one hundred parts. When this is turned through one division, the object is raised $0.005 \mathrm{~mm}$. or 5 microns, at the same time a clock-spring in contact with teeth registers by a clicking sound. 'If the disk is turned through two divisions, there will be two clicks, etc. In this way is regulated the thickness of the sections cut. When the micrometer screw has been turned through the one hundred divisions, it must be unscrewed, the specimen raised, and the steps of the process repeated. The knife is movable and is drawn across the specimen in making sections.

The base sledge microtome (Fig. 36) has a heavy iron base which supports a sliding-way on which the object-carrier moves.

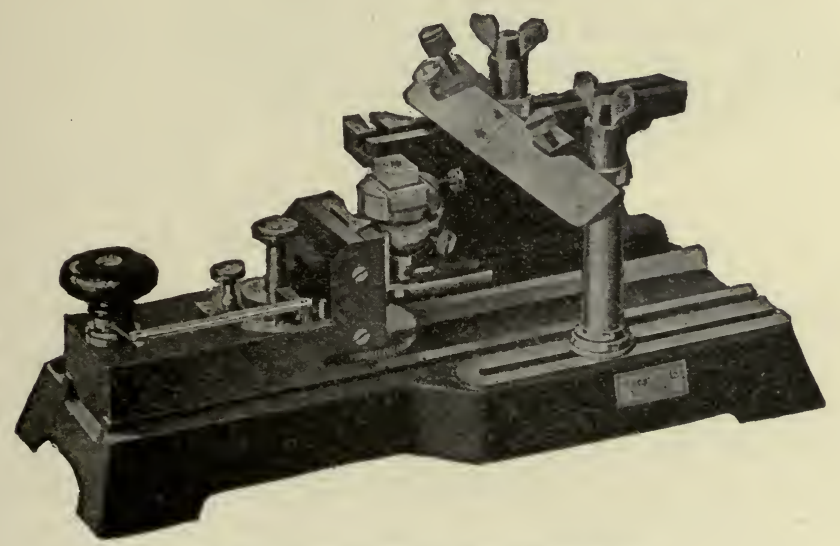

FIG. 36. - Base Sledge Microtome

The object-carrier is mounted on a solid mass of metal, and is provided with a clamp for holding the object. The object is raised by turning a knob which, when turned once, raises the specimen one to twenty microns, according to how the feeding mechanism is set. 
Sections thicker than twenty microns may be obtained by turning the knob two or more times. The knife is fixed and is supported by two pillars, the base of which may be moved forward or backward in such a manner that the knife can be arranged with an oblique or right-angled cutting surface.

The Minot rotary microtome (Fig. 37) has a fixed knife, held in position by two pillars, and a movable object-carrier. The

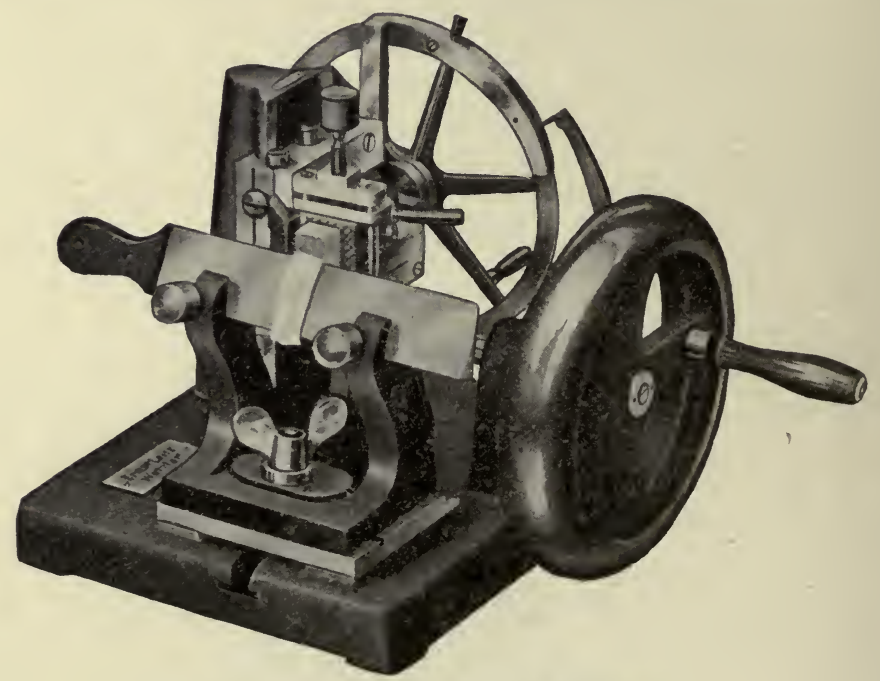

FIG. 37.-Minot Rotary Microtome

object is firmly secured by a clamp, and it is raised by a micrometer screw. The screw is attached to a wheel having five hundred teeth on its periphery. A pawl is adjusted to the teeth in such a way that, when moved by turning a wheel to which it is attached, specimens varying from one to twenty-five microns in thickness may be cut, according to the way the adjusting disk is set. When the mechanism has been regulated and the object adjusted for cutting, it is only necessary to turn a crank in cutting sections.

\section{CARE OF MICROTOMES}

When not in use, microtomes should be protected from dust, and all parts liable to friction should be oiled. 
Microtome knives should be honed as often as is necessary to insure a proper cutting edge. After cutting objects, the knives should be removed, cleaned, and oiled.

It should be kept clearly in mind that special knives are required for cutting collodion, paraffin, and frozen and woody sections. The cutting edges of the different knives vary considerably, as is shown in the preceding cuts. 


\section{CHAPTER V}

\section{REAGENTS}

Little attention is given in the present work to micro-chemical reactions for the reason that their value has been much overrated in the past. A few reagents will be found useful, however, and these few are given, as well as their special use. They are as follows:

\section{LIST OF REAGENTS}

Distilled Water is used in the alcohol, glycerine, and water mixture as a general mounting medium. - It is used when warm as a test for inulin and it is used in preparing various reagents.

Glycerine is used in preparing the alcohol, glycerine, and water mixture, in testing for aleurone grains, and as a temporary mounting medium.

Alcohol is used in preparing the alcohol, glycerine, and water mixture, in testing for volatile oils.

Acetic Acid. Both dilute and strong solutions are used in testing for aleurone grains, cystoliths, and crystals of calcium oxalate.

Hydrochloric Acid is used in connection with phloroglucin as a test for lignin and as a test for calcium oxalate.

Ferric Chloride Solution is used as a test for tannin.

Sulphuric Acid is used as a test for calcium oxalate.

Tincture Alkana is used when freshly prepared by macerating the granulated root with alcohol and filtering, as a test for resin.

Sodium Hydroxide. A five per cent solution is used as a test for suberin and as a clearing agent.

Copper Ammonia is used as a test for cellulose.

Ammonical Solution of Potash is used as a test for fixed oils. The solution is a mixture of equal parts of a saturated solution of potassium hydroxide and stronger ammonia. 
Oil of Cloves is used as a clearing fluid for sections preparatory to mounting in Canada balsam.

Canada Balsam is used as a permanent mounting medium for dehydrated specimens, and as a cement for ringing slides.

Paraffin is used for general embedding and infiltrating.

Lugol's Solution is used as a test for starch and for aleurone grains and proteid matters.

Osmic Acid. A two per cent solution is used as a test for fixed oils.

Alcohol, Glycerine, and Water Mixture is used as a temporary mounting medium and as a qualitative test for fixed oils.

Chlorzinc Iodide is used as a test for suberin, lignin, cellulose, and starch.

Analine Chloride is used as a test for lignified cell walls of bast fibres and of stone cells.

Phloroglucin. A one per cent alcoholic solution is used in connection with hydrochloric acid as a test for lignin.

Hæmatoxylin-Delifields is used as a test for cellulose.

REAGENT SET

Each worker should be provided with a set of reagent bottles (Fig. 38). Such a set may be selected according to the taste

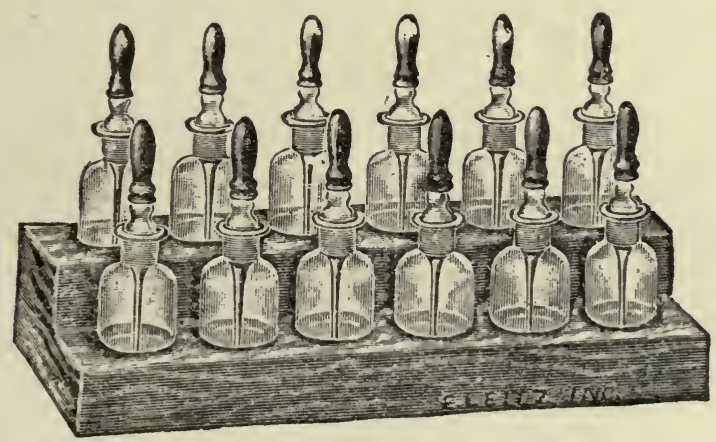

FIG. 38.-Reagent Set

of the individual, but experience has shown that a 30 c.c. bottle with a ground-in pipette and a rubber bulb is preferable to other types. In such forms the pipettes are readily cleaned, and the rubber bulbs can be replaced when they become old and brittle. 
The entire set should be protected from dust by keeping it in a case, the cover of which should be closed when the set is not in use.

\section{MEASURING CYLINDER}

In order accurately to measure micro-chemical reagents, it is necessary to have a standard 50 c.c. cylinder (Fig. 39) graduated

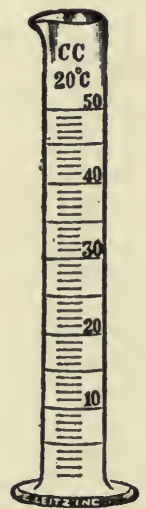

FIG. 39.-Measuring Cylinder

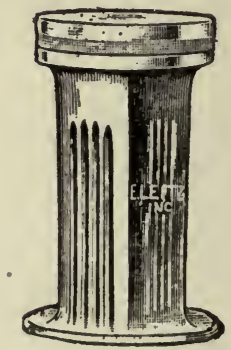

FIG. 40.- Staining Dish

to c.c.'s. Such a cylinder should form a part of the reagent set.

STAINING DISHES

There is a great variety of staining dishes (Fig. 40), but for general histological work a glass staining dish with groves for holding six or more slides and a glass cover is most desirable. 


\section{CHAPTER VI}

\section{HOW TO MOUNT SPECIMENS}

The method of procedure in mounting specimens for study varies according to the nature of the specimen, its preliminary treatment, and the character of the mount to be made. As to duration, mounts are either temporary or permanent.

\section{TEMPORARY MOUNTS}

In preparing a temporary mount, place the specimen in the centre of a clean slide and add two or more drops of the temporary mounting medium, which may be water, or a mixture of equal parts of alcohol, glycerine, and water, or some microchemical reagent, as weak Lugol's solution, solution of chloral hydrate, etc. Cover this with a cover glass and press down gently. Remove the excess of the mounting medium with a piece of blotting paper. Now place the slide on the stage and proceed to examine it. Such mounts can of course be used only for short periods of study; and when the period of observation is finished, the specimen should be removed and the slide washed, or the slide washing may be deferred until a number of such slides have accumulated. At any rate, when the mounting medium dries, the specimen is no longer suitable for observation.

\section{PERMANENT MOUNTS}

Permanent mounts are prepared in much the same way as temporary, but of course the mounting medium is different. The kind of permanent mounting medium used depends upon the previous treatment of the specimen. If the specimen has been preserved in alcohol or glycerine and water, it is usually mounted in glycerine jelly. If the specimen in question is a powder, it is placed in the centre of the slide and a drop or two 
of glycerine, alcohol, and water mixture added, unless the powder was already in suspension in such a mixture. Cut a small cube of glycerine jelly and place it in the centre of the powder mixture. Lift up the slide by means of pliers, or grasp the two edges between the thumb and finger and hold over a small flame of an alcohol lamp, or place on a steam-bath until the glycerine jelly has melted. Next sterilize a dissecting needle, $\mathrm{cool}$, and mix the powder with the glycerine jelly, being careful not to lift the point of the needle from the slide during the operation. If the mixing has been carefully done, few or no air-bubbles will be present; but if they are present, heat the needle, and while it is white hot touch the bubbles with its point, and they will disappear. Now take a pair of forceps and, after securing a clean cover glass near the edge, pass them three times through the flame of the alcohol lamp. While holding it in a slanting position, touch one side of the powder mixture and slowly lower the cover glass until it comes in complete contact with the mixture. Now press gently with the end of the needlehandle, and set it aside to cool. When it is cool, place a neatly trimmed label on one end of the slide, on which write the name of the specimen, the number of the series of which it is to form a part, etc. Any excess of glycerine jelly, which may have been pressed out from the edges of the cover glass, should not be removed at once, but should be allowed to remain on the slide for at least one month in order to allow for shrinkage due to evaporation. At the end of a month remove the glycerine jelly by first passing the blade of a knife, held in a vertical position, the back of the knife being next- to the slide, around the edge of the cover glass. After turning the knife-blade so that the flat side is in contact with slide, remove the jelly outside of the cover glass. Any remaining fragments should be removed with a piece of old linen or cotton cloth. Finally, ring the edge of the cover glass with microscopical cement, of which there are many types to be had. If the cleaning has been done thoroughly, there is no better ringing cement than Canada balsam.

In mounting cross-sections, the method of procedure is similar to the above, with the exception that the glycerine jelly is placed at the side of the specimen and not in the centre. 
While melting the jelly, incline the slide in order to allow the melted glycerine jelly to flow gradually over the specimen, thus replacing the air contained in the cells and intercellular spaces. Finish the mounting as directed above, but under no conditions should you stir the glycerine jelly with the section.

If specimens, after having been embedded in paraffin or collodion, are cut, cleared, stained, and dehydrated, they are usually mounted in Canada balsam. A small drop of this substance, which may be obtained in collapsible tubes, is placed at one side of the specimen. While inclining the slide, gently heat until the Canada balsam covers the specimen. Secure a cover glass by the aid of pliers, pass it through the flame three times, and lower it slowly while holding it in an inclined position. Press gently on the cover glass with the needle-handle, and keep in a horizontal position for twenty-four hours, then place directly in a slide box or cabinet, since no sealing is required.

Glycerine is sometimes used to make permanent mounts, but it is unsatisfactory, because the cover glass is easily removed and the specimen spoiled or lost, unless ringed-a procedure which is not easily accomplished. If the specimen is to be mounted in glycerine, it must first be placed in a mixture of alcohol, glycerine, and water, and then transferred to glycerine. Lactic acid is another permanent liquid-mounting medium, which is unsatisfactory in the same way as glycerine, but like glycerine, there are certain special cases where it is desirable to use it. When this is used, the slides should be kept in a horizontal position, unless ringed.

\section{COVER GLASSES}

Great care should be used in the selection of cover glasses, however, not only as regards their shape but as to their thickness. The standard tube length of the different manufacturers makes an allowance of a definite thickness for cover glasses. It is necessary, therefore, to use cover glasses made by the manufacturer of the microscope in use.

Cover glasses are either square or round. Of each there are four different thicknesses and two different sizes. The standard thicknesses are: 
The small size is designated three-fourths and the large size seven-eighths.

Cover glasses are circular (Fig. 4I), square (Fig. 42), or rectangular (Fig. 43) pieces of transparent glass used in covering the specimens mounted on glass slides. A few years ago much difficulty was experienced in obtaining uniformly thick and

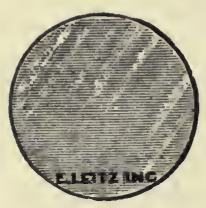

Fig. 4I.-Round Cover Glass

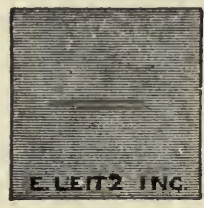

FIG. 42.-Square Cover Glass

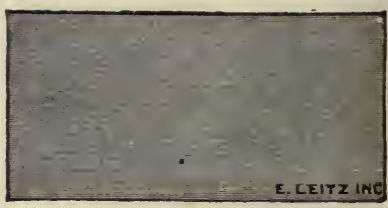

FIG. 43.-Rectangular Cover Glass

transparent cover glasses, but no such difficulty is experienced to-day. The type of cover glass used depends largely upon the character of the specimen to be mounted. The square and rectangular glasses are selected when a series of specimens are to be mounted, but in mounting powdered drugs and histological specimens the round cover glasses are preferable because they are more sightly and more readily cleaned and rinsed.

\section{GLASS SLIDES}

Glass slides (Fig. 44) are rectangular pieces of transparent glass used as a mounting surface for microscopic objects. The

E. LEITZINC

FiG. 44.-Glass Slide

slides are usually three inches long by one inch wide, and they should be composed of white glass, and they should have ground 
and beveled edges. Slides should be of uniform thickness, and they should not become cloudy upon standing

\section{SLIDE AND COVER-GLASS FORCEPS}

Slides and cover glasses should be grasped by their edges. To the beginner this is not easy. In order to facilitate holding slides and cover glasses during the mounting process, one may use a slide and a cover-glass forceps. The slide forceps consists of wire bent and twisted in such a way that it holds a slide firmly when attached to its two edges.

There are various forms of cover-glass holders, but only two types as far as the method of securing the cover glass is con-

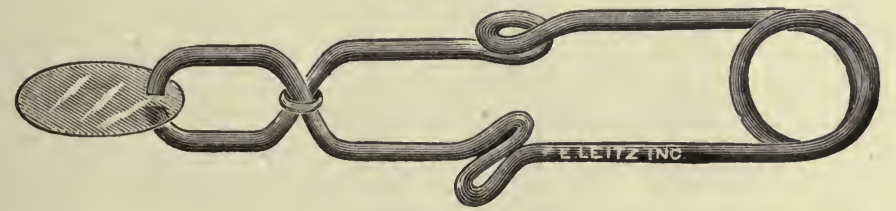

FIG. 45.-Histological Forceps

cerned. First, there are the bacteriological and the histological forceps (Fig. 45), which are self-closing. The two blades of such forceps must be forced apart by pressure in securing the cover glass. The second type of forceps is that in which the two blades are normally separated (Fig. 46), it being necessary to

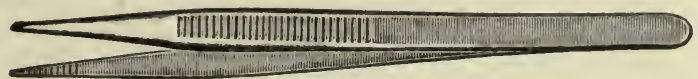

FIG. 46.-Forceps

press the blades to either side of the cover glass in order to secure and hold it. There is a modification of this type of

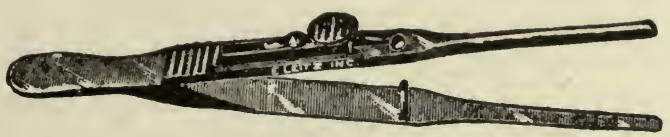

FIG. 47.-Sliding-pin Forceps

forceps which enables one to lock the blades by means of a sliding pin (Fig. 47), after the cover glass has been secured. It is 
well to accustom oneself to one type, for by so doing one may become dexterous in its use.

\section{NEEDLES}

Two dissecting needles (Fig. 48) should form a part of the histologist's mounting set. The handles mav be of any material,

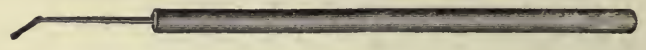

FIG. 48.-Dissecting Needle

but the needle should be of tempered steel and about two inches long.

\section{SCISSORS}

Almost any sort of scissors (Fig. 49) will do for histology work. but a small scissors with fine pointed blades, are preferred.

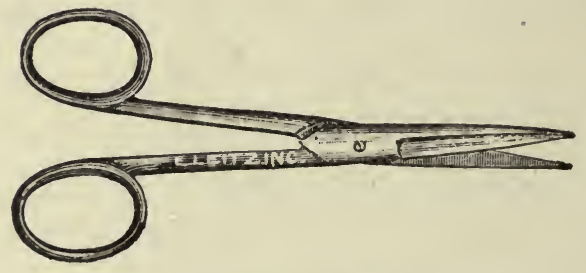

FIG. 49.-Scissors

Scissors are useful in trimming labels and in cutting strips of leaves and sections of fibrous roots that are to be embedded and cut.

\section{SCALPELS}

Scalpels (Fig. 50) have steel blades and ebony handles. These vary in regard to size and quality of material. The cheaper grades are quite as satisfactory, however, as the more expensive ones, and for general use a medium-sized blade and handle will be found most useful.

\section{TURNTABLE}

Much time and energy may be saved by ringing slides on a turntable (Fig. $5 \mathrm{I}$ ). There is a flat surface upon which to rest the hand holding the brush with cement, and a revolving table 
upon which the slide to be ringed is held by means of two clips. In ringing slides, it is only necessary to revolve the table, and
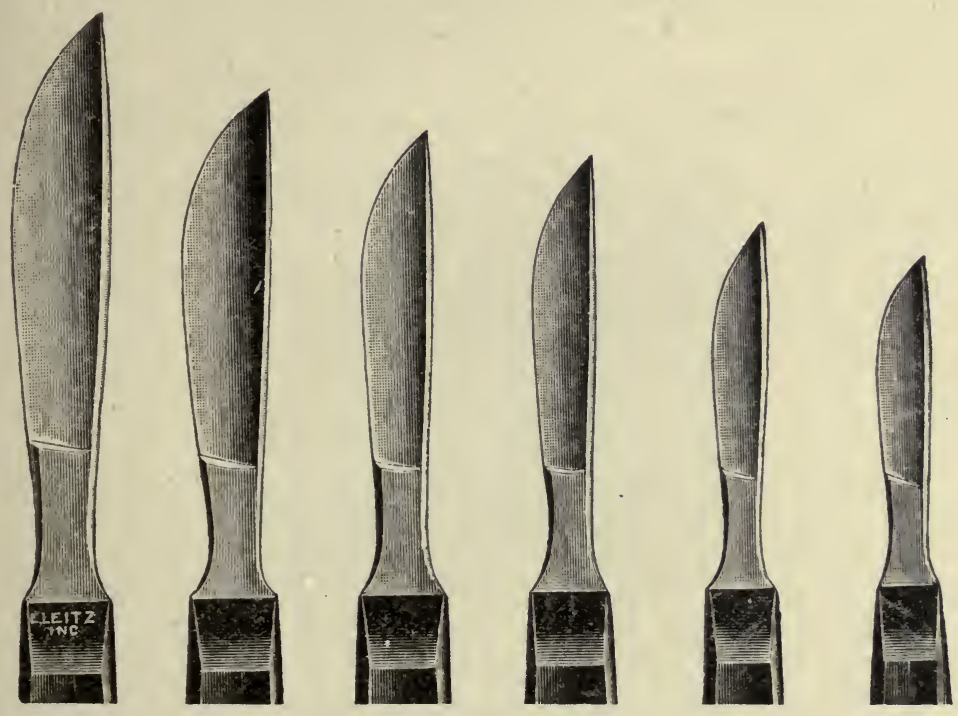

FIG. 50.-Scalpels

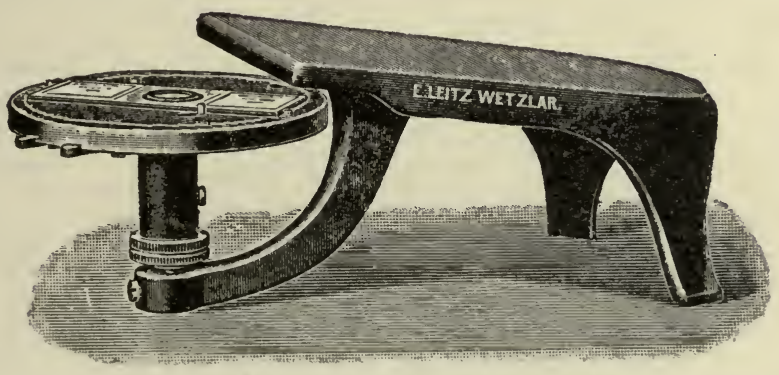

Fig. 51.-Turntable

at the same time to transfer the cement to the edge of the cover glass from the brush held in the hand.

\section{LABELING}

There are many ways of labeling slides, but the best method is to place on the label the name of the specimen, the powder 
number, and the box, the tray or cabinet number. For example:

$$
\begin{gathered}
\text { Powdered Arnica Flowers } \\
\text { No. 80-Box A-600. }
\end{gathered}
$$

\section{PRESERVATION OF MOUNTED SPECIMENS}

Accurately mounted, labeled, and ringed slides should be filed away for future study and reference. Such filing may

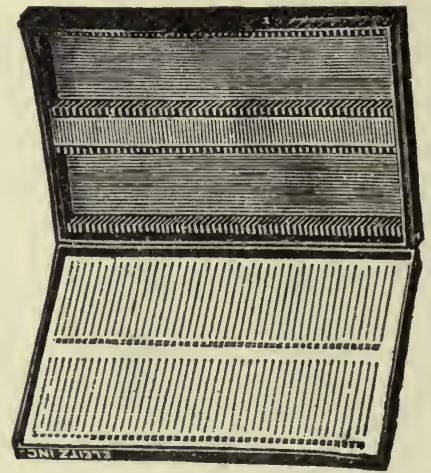

FIG. 52.- Slide Box

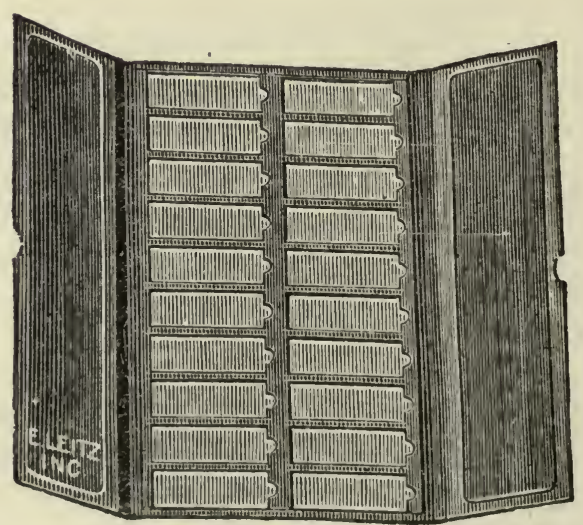

Fig. 53.- Slide Tray

be done in slide boxes, in slide trays, or in cabinets. Slide boxes are to be had of a holding capacity varying from one to 
one hundred slides. For general use, slide boxes (Fig. $5^{2}$ ) holding one hundred slides will be found most useful. Some workers prefer trays (Fig. 53), because of the saving of time in selecting specimens. Trays hold twenty slides arranged in two rows. The cover of the tray is divided into two sections so that, if

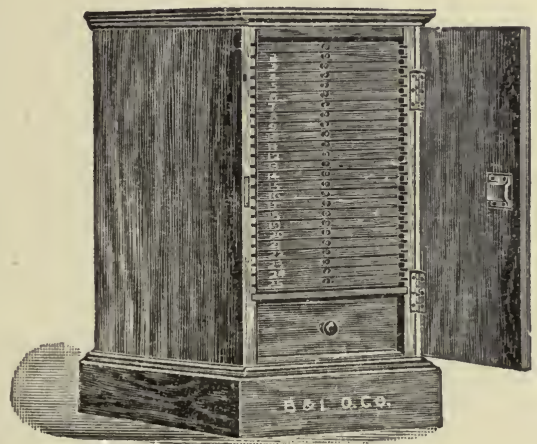

- FIG. 54. - Slide Cabinet

desired, only one row of slides is uncovered at a time. Slide cabinets (Fig. 54) are particularly desirable for storing large individual collections, particularly when the slides are used frequently for reference. Large selections of slides should be numbered and card indexed in order to facilitate finding. 



\section{Part II}

\section{TISSUES CELLS, AND CELL CONTENTS}





\section{CHAPTER I}

\section{THE CELL}

The cell is the unit of structure of all plants. In fact the cell is the plant in many of the lower forms-so called unicellular plants. All plants, then, consist of one or more cells.

While cells vary greatly in size, form, color, contents, and function, still in certain respects their structure is identical.

\section{TYPICAL CELL}

The typical vegetable cell is composed of a living portion or protoplast and an external covering, or wall. The protoplast includes everything within the wall. It is made up of a number of parts, each part performing certain functions yet harmonizing with the work of the cell as a whole. The protoplast (protoplasm) is a viscid substance resembling the white of an egg. The protoplast, when unstained and unmagnified, appears structureless, but when stained with dyes and magnified, it is found to be highly organized. The two most striking parts of the protoplast are the cytoplasm and the nucleus. The part of the protoplast lining the innermost part of the wall is the ectoplast, which is less granular and slightly denser than most of the cytoplasm. The cytoplasm is decidedly granular in structure.

In the cytoplasm occurs one or more cavities, vacuoles, filled with cell sap. Embedded in the cytoplasm are numerous chromatophores, which vary in color in the different cells, from colorless to yellow, to red, and to green. The nucleus is the seat of the vital activity of the cell, and the seat of heredity. The whole life and activity of the cell centre, therefore, in and about the nucleus.

The outer portion of the nucelus consists of a thin membrane or wall. The membrane encloses numerous granular particles- 
chromatin-which are highly susceptible to organic stains. Among the granules are thread-like particles or linin. Near the centre of the nucelus are one or more small rounded nucleoli. The liquid portion of the nucleus, filling the membranes and surrounding the chromatin, linin, and nucleoli, is the nuclear sap.

Other cell contents characteristic of certain cells are crystals, starch, aleurone, oil, and alkaloids. The detailed discussion of these substances will be deferred until a later chapter.

The cell wall which surrounds the protoplast is a product of its activity. The structure and composition of the wall of any given cell vary according to the ultimate function of the cell. The walls may be thin or thick, porous or non-porous, and colored or colorless. The composition of cell walls varies greatly. The majority of cell walls are composed of cellulose, in other cells of linin, in others of cutin, and in still others of suberin, etc. In the majority of cells the walls are laid down in a series of layers one over the other by apposition, similar to the manner of building a pile of paper from separate sheets. The first layer is deposited over the primary wall, formed during cell division; to this is added another layer, etc. A modification of this manner of growth is that in which the layers are built up one over the other, but the building is gradually done by the deposit of minute particles of cell-wall substance over the older deposits. Such walls are never striated, as is likely to be the case in cell walls formed by the first method. In other cells the walls are increased in thickness by the deposition of new wall material in the older membrane. The cell walls will be discussed more fully when the different tissues are studied in detail.

\section{INDIRECT CELL DIVISION (KARYOKINESIS)}

The purpose of cell division is to increase the number of cells of a tissue, an organ, an organism, or to increase the number of organisms, etc. Such cell divisions involve, first, an equal division of the protoplast and, secondly, the formation of a wall between the divided protoplasts. The first changes in structure of a cell undergoing division occur in the nucleus. 


\section{CHANGES IN A CELL UNDERGOING DIVISION}

The linin threads become thicker and shorter. The chromatin granules increase in size and amount; the threads and chromatin granules separate into a definite number of segments or chromosomes (Plate I, Fig. 2). The nuclear membrane becomes invested with a fibrous protoplasmic layer which later separates and passes into either end of the cell. there forming the polar caps (Plate I, Fig. 3).

The nuclear membrane and the nucleoli disappear at about this time. Two fibres, one from each polar cap, become attached to opposite sides of the individual chromosomes. Other fibres from the two polar caps unite to form the spindle fibres, which thus extend from pole to pole. All these spindle fibres form the nuclear spindle (Plate I, Fig. 5).

The chromosomes now pass toward the division centre of the cell or equatorial plane and form, collectively, the equatorial plate (Plate I, Fig. 5). At this point of cell division, the chromosomes are U-shaped, and the curved part of the chromosomes faces the equatorial plane. The chromosomes finally split into two equal parts (Plate I, Fig. 6). The actual separation of the halves of chromosomes is brought about by the attached polar fibres, which contract toward the polar caps (Plate I, Fig. 7). The chromosomes are finally drawn to the polar caps (Plate I, Fig. 8). The chromosomes now form a rounded mass. They then separate into linin threads and chromatin granules. Nucleoli reappear, and nuclear sap forms. Finally, a nuclear membrane develops. The spindle fibres, which still extend from pole to pole, become thickened at the equatorial plane (Plate I, Fig. 8), and finally their edges become united to form the cellplate (Plate I, Fig. 9), which extends across the cell, thus completely separating the mother cell into two daughter cells. After the formation of the cell-plate, the spindle fibres disappear. The cell becomes modified to form the middle lamella, on either side of which the daughter protoplast adds a cellulose layer. The ultimate composition of the middle lamella and the composition and structure of the cell wall will differ according to the function which the cell will finally perform. 


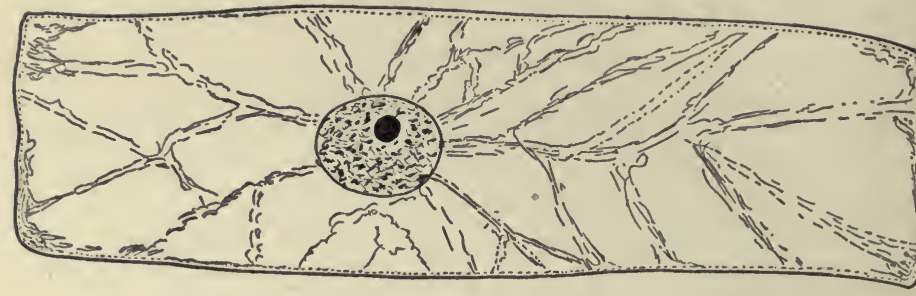

0 这
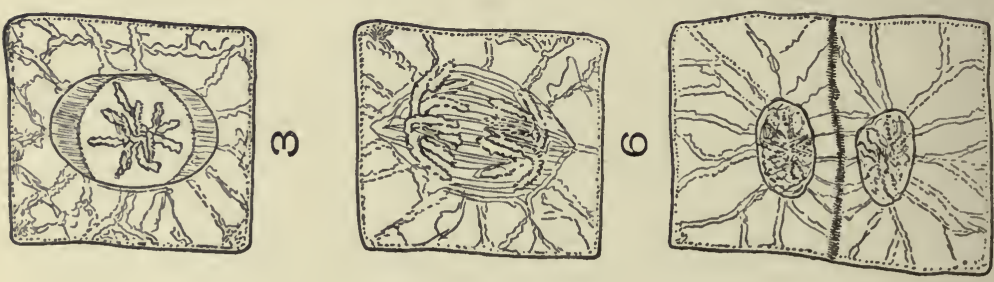

응

•ำำ

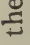

a)

हू
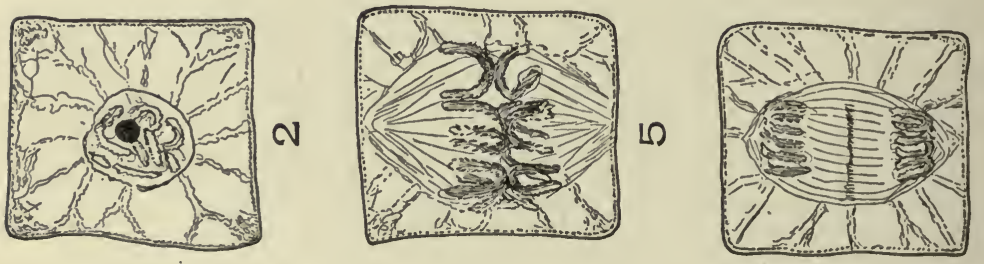

10
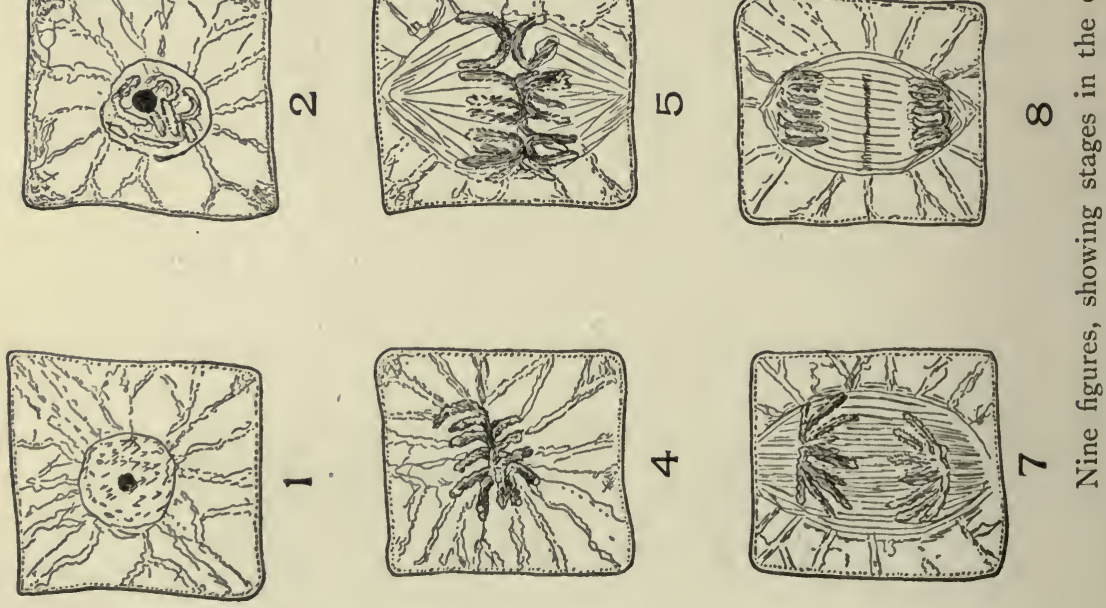


\section{ORIGIN OF MULTICELLULAR PLANTS}

All multicellular plants are built up by the repeated cell division of one original cell. If the cells formed are similar in structure and function, they form a tissue. In multicellular plants many different kinds of tissues will be formed as a result of cell division, since there are many different functions to be performed by such an organism. When several of these tissues become associated and their functions are correlated, they form an organ. The association of several organs in one form makes an organism. The oak-tree is an organism. It is made up of organs known as flowers, leaves, stems, roots, etc. Each of these organs is in turn made up of several kinds of tissue. In some cases it is difficult to designate a single function to an aggregation of cells (tissue). In fact, a tissue may perform different functions at different periods of its existence or it may perform two functions at one and the same time; as an example, stone cells, whose primary function is mechanical, in many cases function as storage tissue. The cells forming the tissues of the plant, in fact, show great adaptability in regard to the function which they perform. Nevertheless there is a predominating function which all tissues perform, and the structure of the cells forming such tissues is so uniform that it is possible to classify them.

The functional classification of tissues is chosen for the purpose of demonstrating the adaptation of cell structure to cell function. If the cells performing a similar function in the different plants were identical in number, distribution, form, color, size, structure, and cell contents, there would not be a science of histology upon which the art of microscopic pharmacognosy is based. It may be said, however, with certainty, that the cells forming certain of the tissues of any given species of plant will differ in a recognizable degree from cells performing a similar function in other species of plants. Often a tissue is present in one plant but absent in another. For example, many aquatic plants are devoid of mechanical fibrous cells. The barks of certain plants have characteristic stone cells, while in many other barks no stone cells occur. Many leaves have characteristic trichomes; others are free from trichomes, etc. 
Yet all cells performing a given function will structurally resemble each other. In the present work the nucleus and other parts of the living protoplast will not be considered, for the reason that these parts are not in a condition suitable for study, because most drugs come to market in a dried condition, a condition which eliminates the possibility of studying the protoplast. The general structure of the cells forming the different tissues will first be considered, then their variation, as seen in different plants, and finally their functions. 


\section{CHAPTER II}

\section{THE EPIDERMIS AND PERIDERM}

The epidermis and its modifications, the hypodermis and the periderm, form the dermal or protective outer layer or layers of the plant.

The epidermis of most leaves, stems of herbs, seeds, fruits, floral organs, and young woody stems consists of a single layer. of cells which form an impervious outer covering, with the exception of the stoma.

\section{LEAF EPIDERMIS}

The cells of the epidermis vary in size, in thickness of the side and end walls, in form, in arrangement, in character of outgrowths, in the nature of the surface deposits, in the character of wall-whether smooth or rough-and in size.

In cross-sections of the leaf the character of both the side and end walls is easily studied.

In surface sections-the view most frequently seen in powders - the side walls are more conspicuous than the end wall (Plates 2 and 3). This is so because the light is considerably retarded in passing through the entire length of the side walls, while the light is retarded only slightly in passing through the end wall. The light in this case passes through the width (thickness) of the wall only. The outer walls of epidermal cells are characteristic only when they are striated, rough, pitted, colored, etc. In the majority of leaves the outer wall of the epidermal cells is not diagnostic in powders, or in surface sections.

The thickness of the end and side walls of epidermal cells differs greatly in different plants.

As a rule, leaves of aquatic and shade-loving plants, as well as the leaves of most herbs have thinner walled epidermal cells 


\section{PLATE $^{-} 2$}
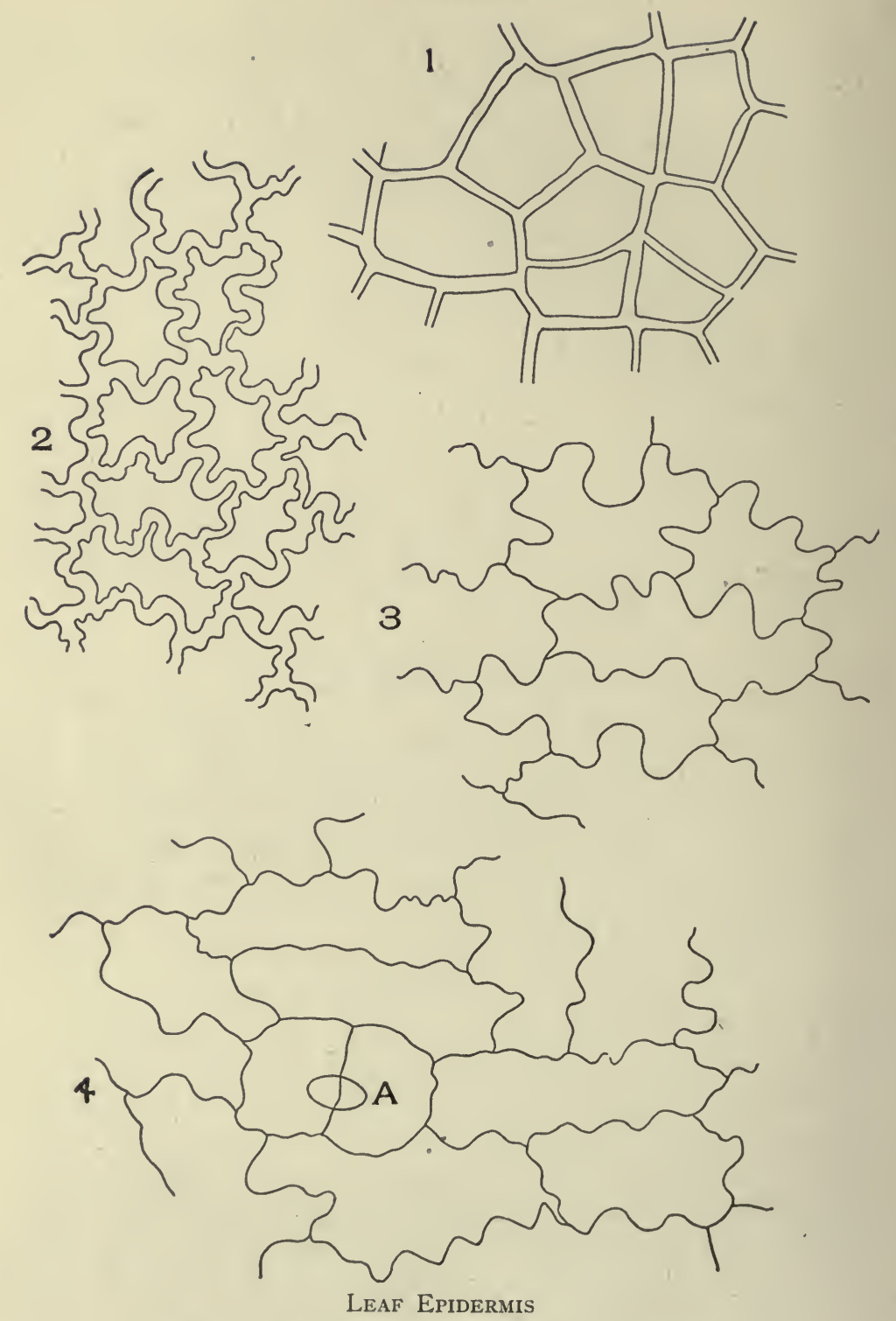

I. Uva-ursi (Arctostaphylos uva-ursi, [L.] Spring).

2. Boldus (Peumus boldus, Molina).

3. Catnip (Nepeta cataria, L.).

4. Digitalis (Digitalis purpurea, L.). 4-A. Origin of hair. 
PLATE 3
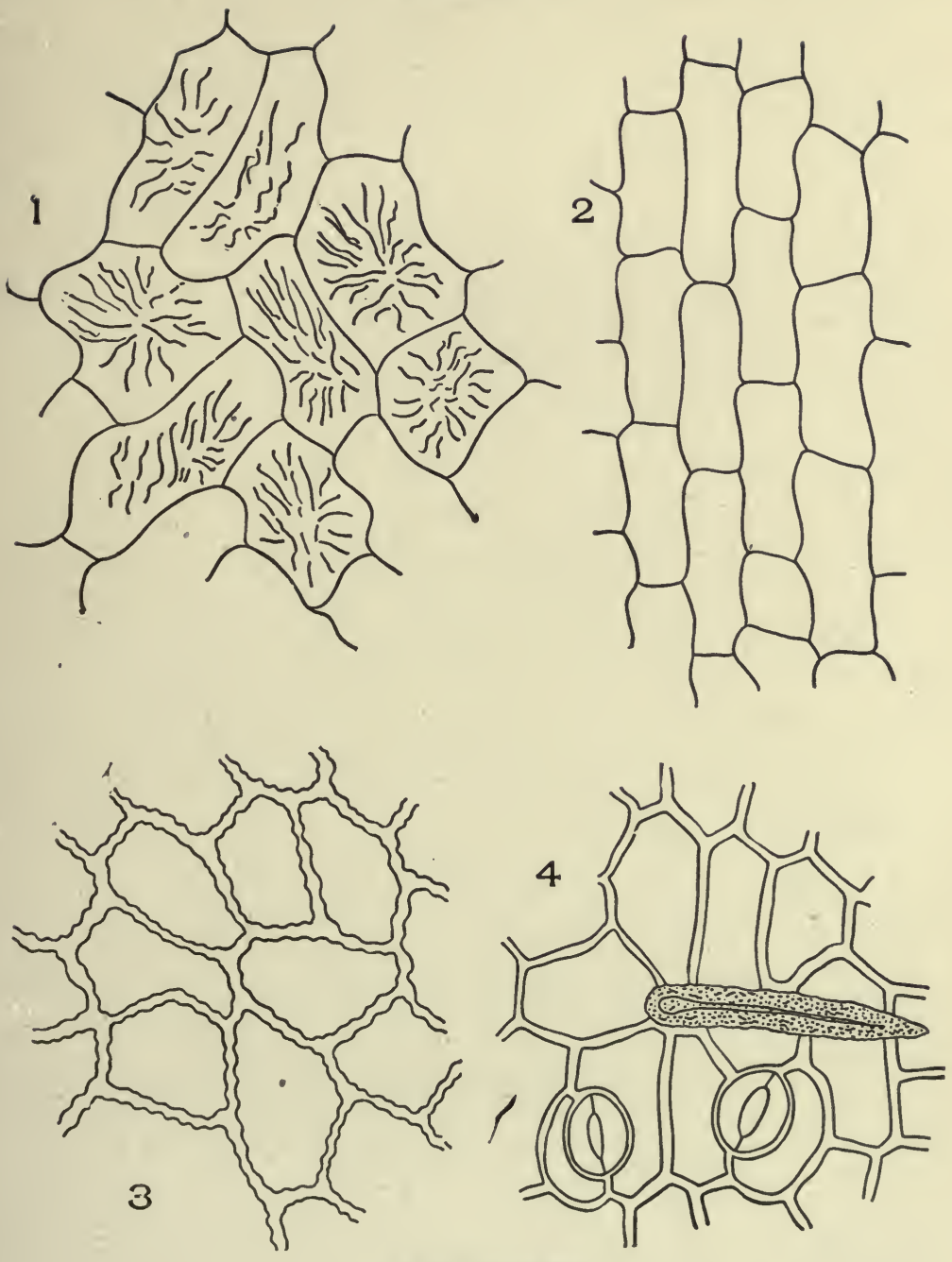

LEAF EPIDERMIS

I. Upper striated epidermis of chirata leaf (Swertia chirata, [Roxb.] Ham.).

2. Green hellebore leaf (Veratrum viride, Ait.).

3. Boldus leaf (Peumus boldus, Molina).

4. Under epidermis of India senna (Cassia angustifolia, Vahl.). 
than have the leaves of plants growing in soil under normal conditions, or than have the leaves of shrubs and trees.

The widest possible range of cell-wall thickness is therefore found in the medicinal leaves, because the medicinal leaves are collected from aquatic plants, herbs, shrubs, trees, etc.

The outer wall is always thicker than the side walls. Even the side walls vary in thickness in some leaves, the wall next to the epidermis being thicker than the lower or innermost portion of the wall. Frequently the outermost part of the side walls is unequally thickened. This is the case in the beaded side walls characteristic of the epidermis of the leaves of laurus, myrcia, boldus, and capsicum seed, etc. The thickness of the side walls of the epidermal cells of most leaves varies in the different leaves.

In most leaves there are five typical forms of arrangement of epidermal calls: First, those over the veins which are elongated in the direction of the length of the leaf; and, secondly, those on other parts of the leaf which are usually several-sided and not elongated in any one direction. If the epidermis of the leaf has stoma, then there is a third type of arrangement of the epidermal cells around the stoma; fourthly, the cells surrounding the base of hairs; and fifthly, outgrowths of the epidermis, non-glandular and glandular hairs, etc.

It should be borne in mind that in each species of plant the five types of arrangement are characteristic for the species.

The character of the outer wall of the epidermal cells differs greatly in different plants. In most cases the wall is smooth; senna is an example of such leaves. In certain other leaves the wall is rough, the roughness being in the form of striations. In some cases the striations occur in a regular manner; belladonna leaf is typical of such leaves. In other instances the wall is striated in an irregular manner as shown in chirata epidermis. Very often an epidermis is rough, but the roughness is not due to striations. In these cases the epidermis is unevenly thickened, the thin places appearing as slight depressions, the thick places as slight elevations. Boldus has a rough, but not a striated surface.

Surface deposits are not of common occurrence in medicinal plants; waxy deposits occur on the stem of sumac, on a species 
of raspberry, on the fruit of bayberry, etc. Resinous deposits occur on the leaves and stems of grindelia species, and on yerba santa.

In certain leaves there are two or three layers of cells beneath the epidermis that are similar in structure to the epidermal cells. These are called hypodermal cells, and they function in the same way as the epidermal cells.

Hypodermal cells are very likely to occur on the margin of the leaf. Uva-ursi leaf has a structure typical of leaves with hypodermal marginal cells. Uva-ursi, like other leaves with hypodermal cells has a greater number of hypodermal cells at the leaf margin than at any other part of the leaf surface.

The cutinized walls of epidermal cells are stained red with saffranin.

\section{TESTA EPIDERMIS}

Testa epidermal cells form the epidermal layers of such seeds as lobelia, henbane, capsicum, paprika, larkspur, belladonna, scopola, etc.

In surface view the end walls are thick and wavy in outline; frequently the line of union-middle lamella - of two cells is indicated by a dark or light line, while in others the wall between two cells appears as a single wall. The walls are porous or non-porous, and the color of the wall varies from yellow to brown, to colorless. These cells always occur in masses, composed partially of entire and partially of broken fragments.

In lobelia seed (Plate 4, Fig. 2) the line of union of adjacent cell walls appears as a dark line. The walls are wavy in outline, of a yellowish-red color and not porous.

In henbane seed (Plate 4, Fig. 3) the line of union between the cells is scarcely visible; the walls are decidedly wavy, more so than in lobelia, and no pits are visible.

In capsicum seed (Plate 4, Fig. I) the cells are very wavy. and decidedly porous, the line of union between the cell walls being marked with irregular spaces and lines.

In belladonna seed (Plate 5, Fig. I) the walls between two adjacent cells are non-striated and non-porous, and extremely irregular in outline. 
PLATE 4

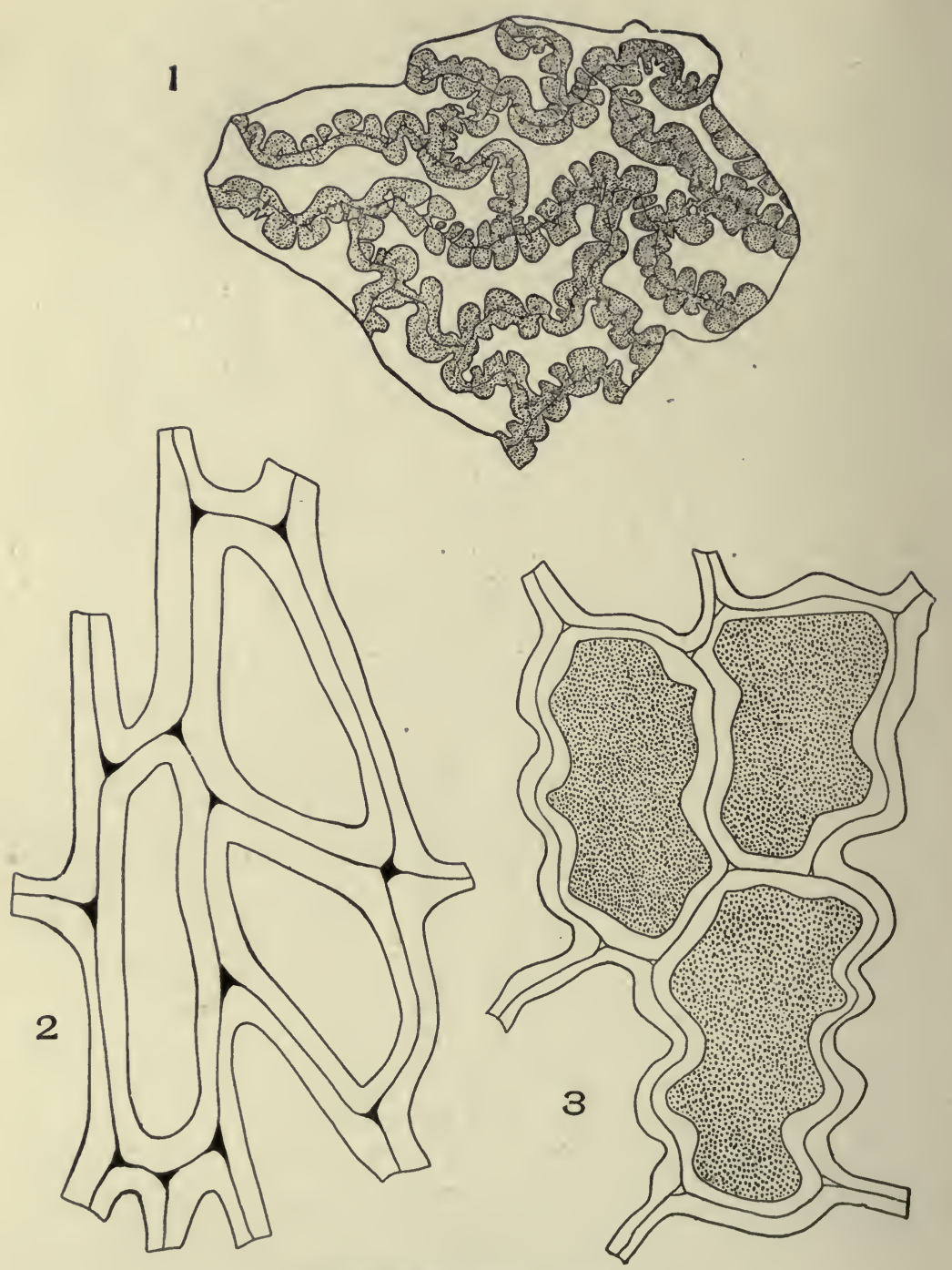

Testa Epidermal Cells

I. Capsicum seed (Capsicum frutescens, L.).

2. Lobelia seed (Lobelia inflata, L.).

3. Henbane seed (Hyoscyamus niger, L.). 
PLATE 5

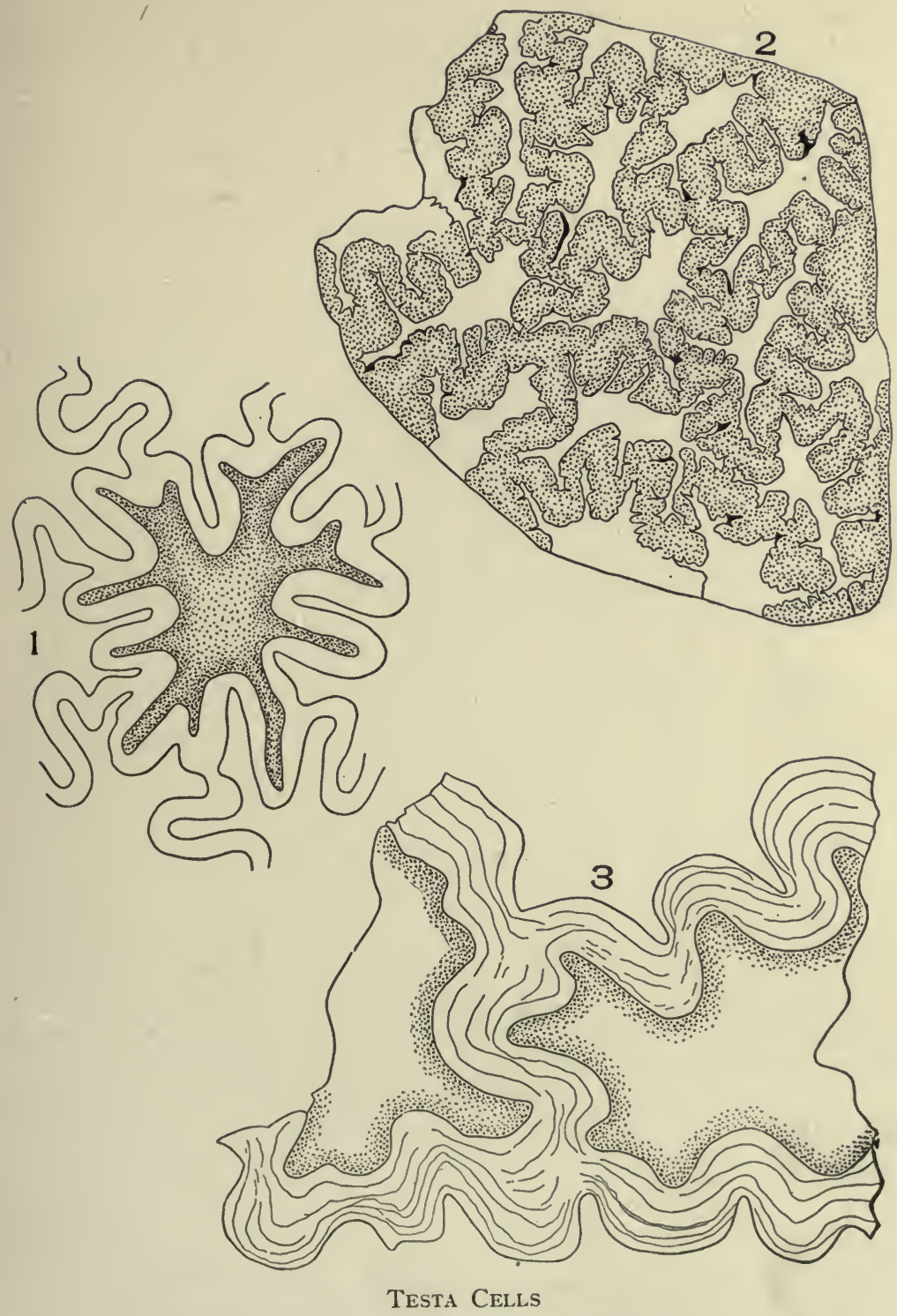

I. Belladonna seed (Atropa belladonna, L.).

2. Star-aniseed (Illicium verum, Hooker).

3. Stramonium seed (Datura stramonium, L.). 
In star-anise seed (Plate 5, Fig. 2) the walls are irregularly thickened and wavy in outline.

In stramonium seed (Plate 5, Fig. 3) the walls are very thick, wavy in outline, and striated.

\section{PLANT HAIRS (TRICHOMES)}

In histological work plant hairs are of great importance, as they offer a ready means of distinguishing and differentiating between plants, or parts of plants, when they occur in a broken or finely powdered condition. There is no other element in powdered drugs which is of so great a diagnostic value as the plant hair. The same plant will always have the same type of hair, the only noticeable variation being in the size. In microscopical drug analysis the presence of hairs is always noted, and in many cases the purity of the powder can be ascertained from the hairs. Botanists seem to have given little attention to the study of plant hairs. This accounts for the fact that information concerning them is very meagre in botanical literature, and, as far as the author can learn, no one has attempted to classify them. In systematic work, plant hairs could be used to great advantage in separating genera and even species. Hairs are, of course, a factor now in systematic work. The lack of hairs is indicated by the term glabrous. Their pressence is indicated by such terms as hispid, villous, etc. In certain cases the term indicates position of the hair as ciliate when the hair is marginal. When hairs influence the color of the leaf, such terms as cinerous and canescent are used. In all the cases cited no mention is made of the real nature of the hair.

In systematic work, as in pharmacognosy, we must work with dried material, and it is only those hairs which retain their form under such conditions which are of classification value.

Hairs are the most common outgrowths of the epidermal cells. They are classified as glandular or non-glandular, according to their structure and function. The glandular hairs will be considered under synthetic tissue.

Each group is again subdivided into a number of secondary groups, depending upon the number of cells present, their form, 
their arrangement, their size, their color, the character of their walls, whether rough or smooth, whether branched or nonbranched, whether curved, twisted, straight, or twisted and straight, whether pointed, blunt, or forked.

\section{FORMS OF HAIRS}

\section{PAPILL $\mathbb{E}$}

Papillæ are epidermal cells which are extended outward in . the form of small tubular outgrowths.

Papillæ occur on the following parts of the plant: flowerpetals, stigmas, styles, leaves, stems, seeds, and fruits. Papillæ occur on only a few of the medicinal leaves.

The under surface of both Truxillo (Plate 6, Fig. 3) and Huanuca coca have very small papillæ. The outermost wall of these papillæ are much thicker than the side walls. The papillæ of klip buchu (Plate 6, Fig. 4), an adulterant of true buchu, has large thick-walled papillæ.

The velvety appearance of most flower-petals (Plate 6, Figs. 2 and 5) is due to the presence of papillæ. The papillæ of flower-petals are very variable. In calendula flowers (Plate 6, Fig. I) they are small, yellowish in color, and the outer wall is marked with parallel striations which appear as small teeth in cross-section. The ray petal papillæ of anthemis consist of rather large, broad, blunt papillæ with slightly striated walls. The papillæ of the ray petals of the white daisy consist of papillæ which have medium sized, cone-shaped papillæ with finely striated walls. The papillæ of the flower stigma vary greatly in different flowers. In some cases two or more types of papillæ occur, but even in these cases the papillæ are characteristic of the species.

The papillæ differ greatly in the case of the flowers of the compositæ, where two types of flowers are normally presentnamely, the ray flowers and the disk flowers.

In all cases observed the papillæ of the stigma of the ray flowers are always smaller than the papillæ of the stigma of the disk flowers. It would appear from extended observation that the papillæ of the ray flower stigma are being gradually aborted. The papillæ of the style are always different from the papillæ 


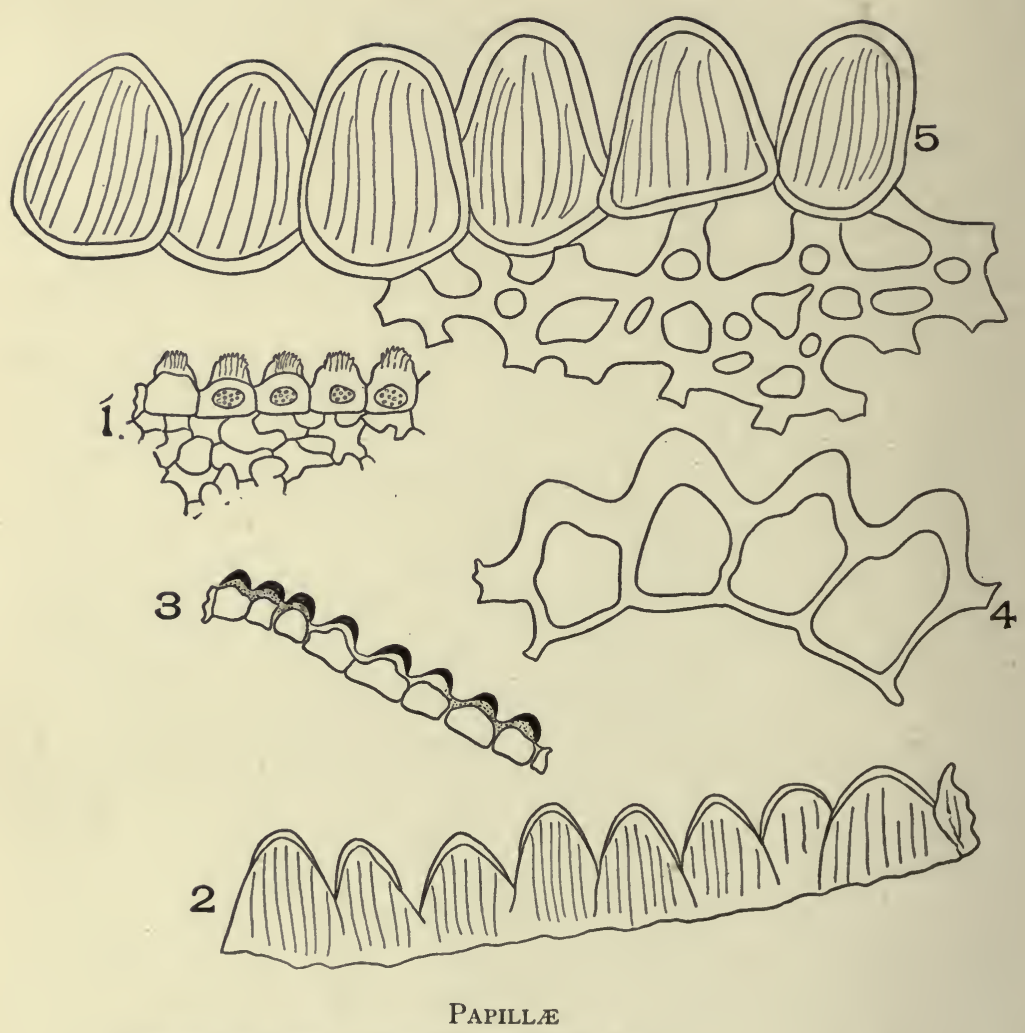

I. Calendula flowers (Calendula officinalis, L.).

2. White daisy ray flower (Chrysanthemum leucanthemum, L.).

3. Coca leaf (Erythroxylon coca, Lamarck).

4. Klip buchu.

5. Anthemis ray petal (Anthemis nobilis, L.). 
of the stigma. The style papillæ are always smaller, and they are of a different form.

\section{UNICELLULAR NON-GLANDULAR HAIRS}

True plant hairs are tubular outgrowths of the epidermal cell, the length of these outgrowths being several times the width of the hair.

The unicellular hairs are common to many plants. The two groups of non-glandular unicellular hairs are, first, the solitary; and secondly, the clustered hairs.

Solitary unicellular hairs occur on the leaves of chestnut, yerba santa, lobelia, cannabis indica, the fruit of anise, and the stem of allspice, senna, and cowage.

Chestnut hairs (Plate 7, Fig. I) have smooth yellowish-colored walls, and the cell cavity contains reddish-brown tannin. These hairs occur solitary or clustered; the clustered hairs normally occur on the leaf, but in powdering the drug, individual hairs of the cluster become separated or solitary.

Yerba santa hairs (Plate 7, Fig. 4) are twisted, the lumen or cell cavity is very small, and the walls, which are very thick, are grayish-white.

Lobelia hairs (Plate 7, Fig. 5) are very large. The walls are grayish-white, and the outer surface extends in the form of small elevations which make the hair very rough. The hair tapers gradually to a solid point.

Cannabis indica hairs (Plate 7 , Fig. 6) are curved. The apex tapers to a point and the base is broad, and it frequently contains deposits of calcium carbonate. The walls are grayishwhite in appearance, and rough. The roughness increases toward the apex.

The hairs of anise (Plate 7, Fig. 7) are mostly curved; the walls are thick, yellowish-white, and the outer surface is rough; this is due to the numerous slight centrifugal projections of the outer wall.

Allspice stem hairs (Plate 7, Fig. 2) have smooth walls. The cell cavity is reddish-brown. The hair is curved.

The hair of senna (Plate 7, Fig. Io) is light greenish-yellow with rough papillose walls. The hair is usually curved and tapering, and it does not have any characteristic cell contents. 


\section{PLATE 7}

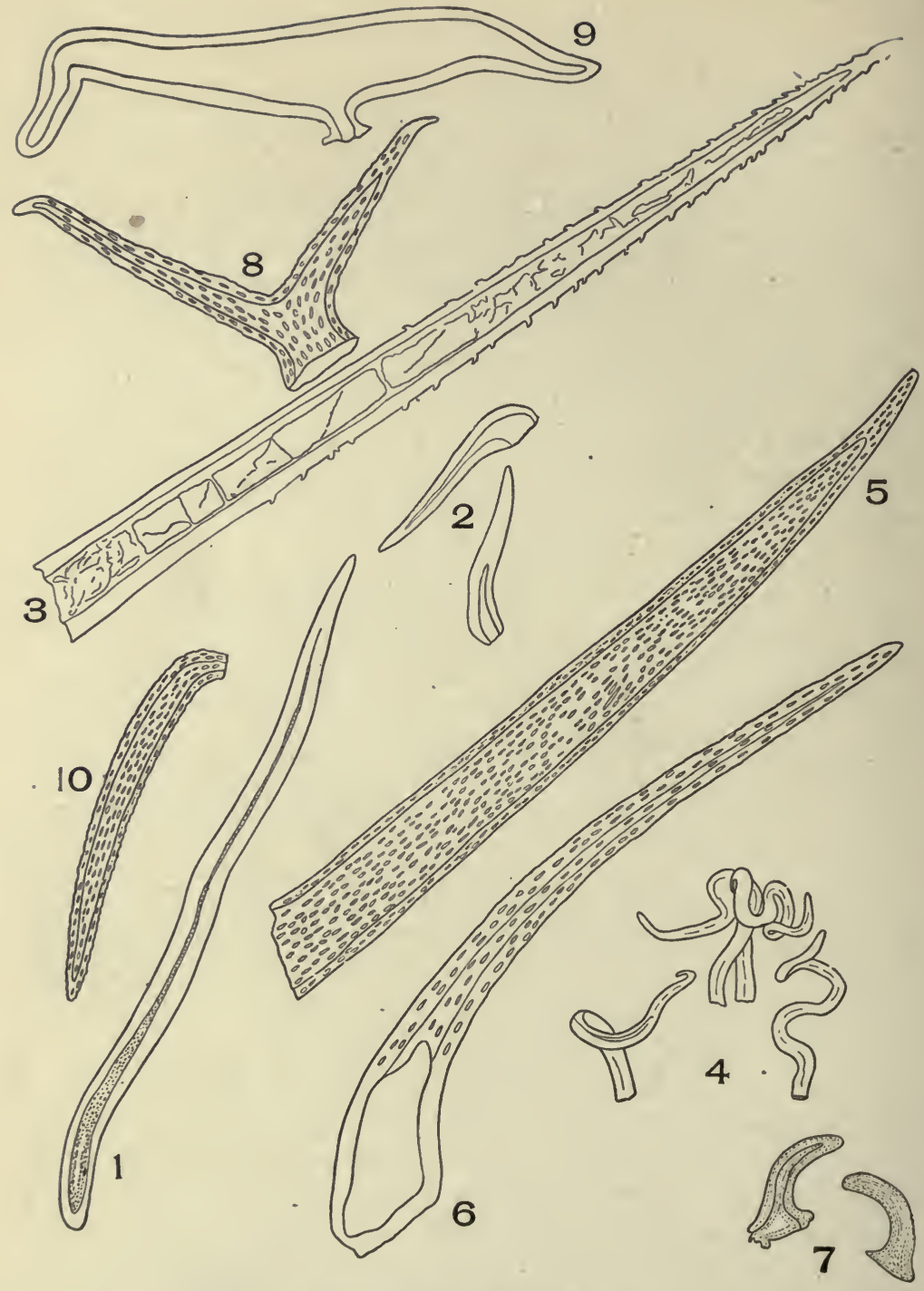

\section{Unicellular Solitary Hairs}

I. Chestnut leaf (Castanea dentata, [Marsh] Borkh).

2. Allspice stems (Pimenta officinalis, Lindi.).

3. Cowage.

4. Yerba santa (Eriodictyon californicum, [H. and A.] Greene).

5. Lobelia (Lobelia inflata, L.).

6. Cannabis indica (Cannabis sativa, L.).

7. Anise fruit (Pimpinella anisum, L.).

8. Hesperis matronalis (Hesperis matronalis, L.).

9. Galphimia glauca (Galphimia glauca, Cav.).

ı. Senna (Cassia angustifolia, Vahl.). 
PLATE 8
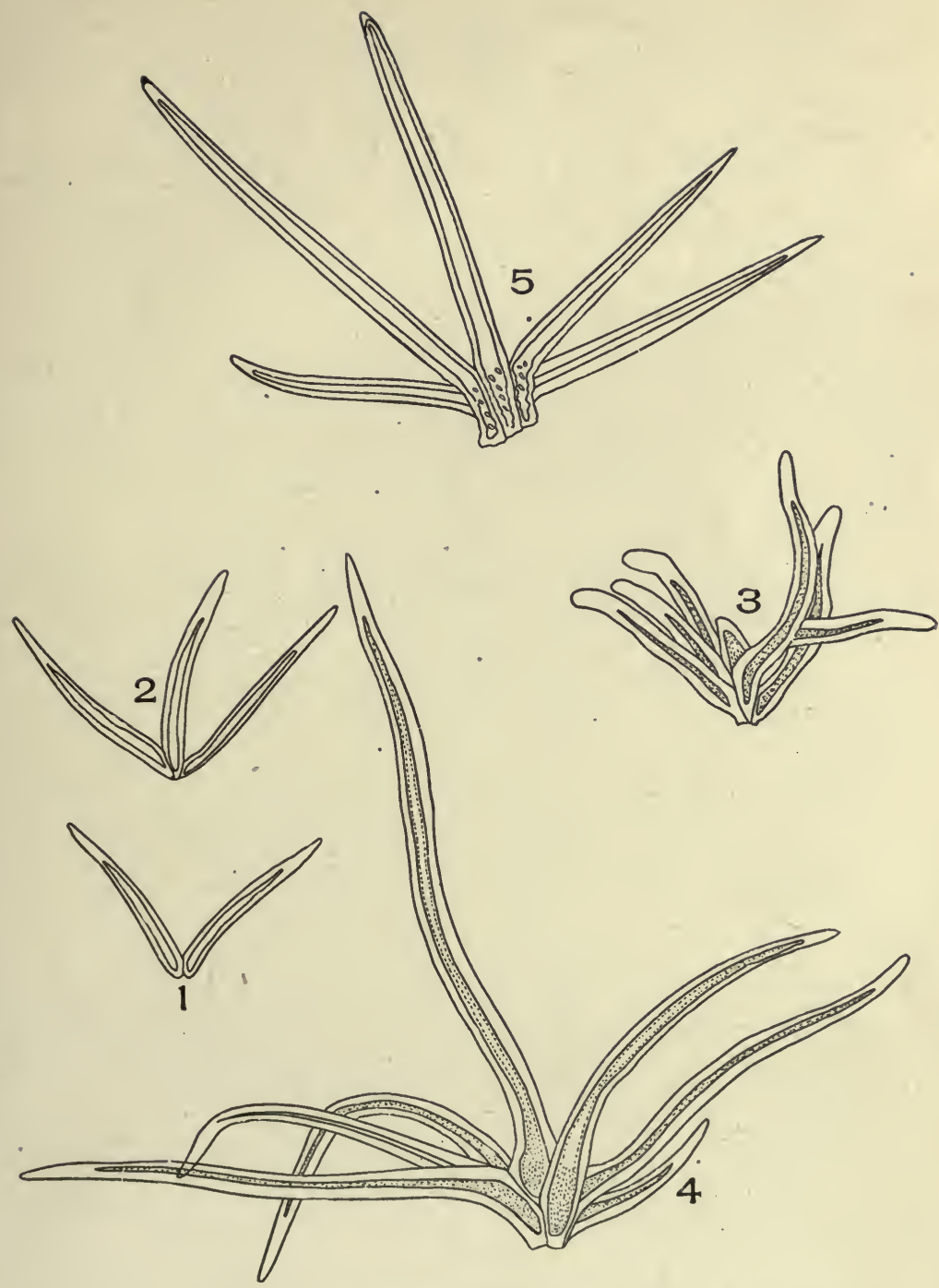

Clustered Unicellular Hairs

I and 2. European oak (Quercus infectoria, Olivier).

3. Kamala (Mallotus philippinensis, [Lam.] [Muell.] Arg.).

4. Witch-hazel leaf (Hamamelis virginiana, L.).

5. Althea leaf (Althae officinalis, L.). 
Cowage hairs (Plate 7, Fig. 3) are lance-shaped, and they terminate in a sharp point. The outer wall contains numerous recurved teeth-like projections. The cell cavity is filled with a reddish-brown contents which are somewhat fissured.

Clustered unicellular hairs occur on the leaves of chestnut, witch-hazel, althea, European oak, etc. In European oak (Plate 8, Figs. I and 2) clusters of two and three hairs occur. The walls are yellowish-white, smooth, and the tip of the hair is solid.

In kamala (Plate 8, Fig. 3) clusters of seven or more hairs occur; the walls are yellowish, and the cell cavity is reddishbrown. In witch-hazel leaf (Plate 8, Fig. 4) clusters of a variable number of hairs occur. The hairs, which are of various lengths, have yellowish-white, thick, smooth walls, and reddish cell contents.

In althea leaf (Plate 8, Fig. 5) the hairs are nearly straight and the walls are smooth. The basal portions of the hair are strongly pitted.

Branched solitary unicellular hairs occur on the leaves of hesperis matronalis (Plate 7 , Fig. 8), and on galphimia glauca (Plate 7; Fig. 9).

The hair of hesperis matronalis has smooth walls, and the two branches grow out nearly parallel to the leaf surface.

The hair of galphimia glauca has rough walls, and the two branches grow upward in a bifurcating manner.

\section{MULTICELLULAR HAIRS}

Multicellular hairs are divided into the uniseriate and the multiseriate hairs. Both of these groups are divided into the branched and the non-branched hairs, as follows:

I. Uniseriate.

(A) Non-branched.

(B) Branched.

2. Multiseriate.

(A) Non-branched.

(B) Branched.

Multicellular uniseriate non-branched hairs occur on the leaves of digitalis, Western and Eastern skullcap, peppermint, thyme, yarrow, arnica flowers, and sumac fruit.

Digitalis hairs (Plate 9, Fig. I) are made up of a varying 
PLATE 9

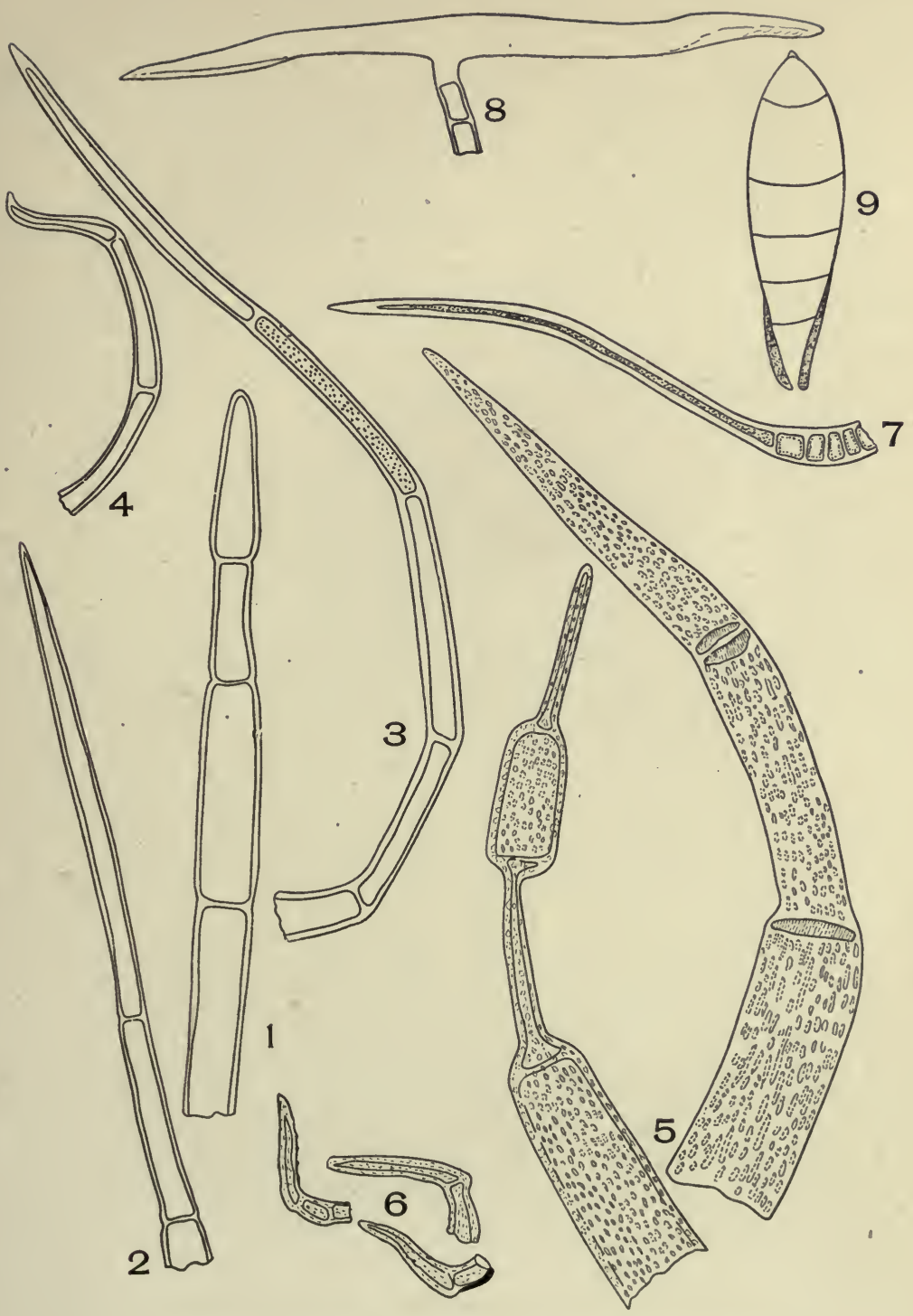

\section{Multicellular Uniseriate Non-Branched Hairs}

I. Digitalis leaf (Digitalis purpurea, L.).

2. Arnica flower (Arnica montana, L.).

3. Western skullcap plant (Scutellaria canescens, Nutt.).

4. Eastern skullcap plant (Scutellaria lateriflora, L.)

5. Peppermint leaf (Mentha piperita, L.).

6. Thyme leaf (Thymus vulgaris, L.).

7. Yarrow flowers (Achillea millefolium, L.).

8. Wormwood leaf (Artemisia absinthium, L.).

9. Sumac fruit (Rhus glabra, L.). 
number of uniseriate-arranged cells of unequal length, frequently placed at right angles to the cells above and below; the walls are of a whitish color, and are rough or smooth.

Eastern skullcap (Plate 9, Fig. 4) has hairs with not more than four cells; these hairs are curved, and the walls are whitish, sometimes smooth, but usually rough. In Western skullcap (Plate 9, Fig. 3) the hairs have sometimes as many as seven cells. The walls are white and rough, and the individual cells of the hair are much larger than are the cells of the hairs of true skullcap.

Peppermint (Plate 9, Fig. 5) has from one to eight cells. The hair is curved, and the walls are very rough.

Thyme (Plate 9, Fig. 6) has short, thick, rough-walled trichomes, the terminal cell usually being bent at nearly right angles to the other cells.

Yarrow hairs (Plate 9, Fig. 7) have a variable number of cells. In all the hairs the basal cells are short and broad, while the terminal cell is greatly elongated.

Arnica hairs (one form, Plate 9, Fig. 2) have frequently as many as four cells, the terminal cell being longer than the basal cells. The walls are white and smooth.

Sumac-fruit hairs (Plate 9, Fig. 9) have spindle-shaped, reddish-colored hairs.

Multicellular multiseriate non-branched hairs occur on cumin fruit and on the tubular part of the corolla of calendula.

The hairs on cumin fruit vary considerably in size. All the hairs are spreading at the base and blunt or rounded at the apex. The cells forming the hair are narrow and the walls are thick: Three differently sized hairs are shown in Plate IO, Fig. I.

The hairs of the base of the ligulate petals of calendula (Plate IO, Fig. 2) are biseriate. The hairs are very long and the walls are very thin.

Multicellular uniseriate branched hairs occur on the leaves of dittany of Crete, mullen, and on the calyx of lavender flowers.

The dittany of Crete (Plate I , Fig. 3) hair is smooth-walled, and the branches are alternate.

In mullen (Plate I I, Fig. I) the hairs have whorled branches, the walls are smooth, and the cell cavity usually contains air.

The lavender hairs (Plate II, Fig. 2) have mostly opposite 
PLATE IO

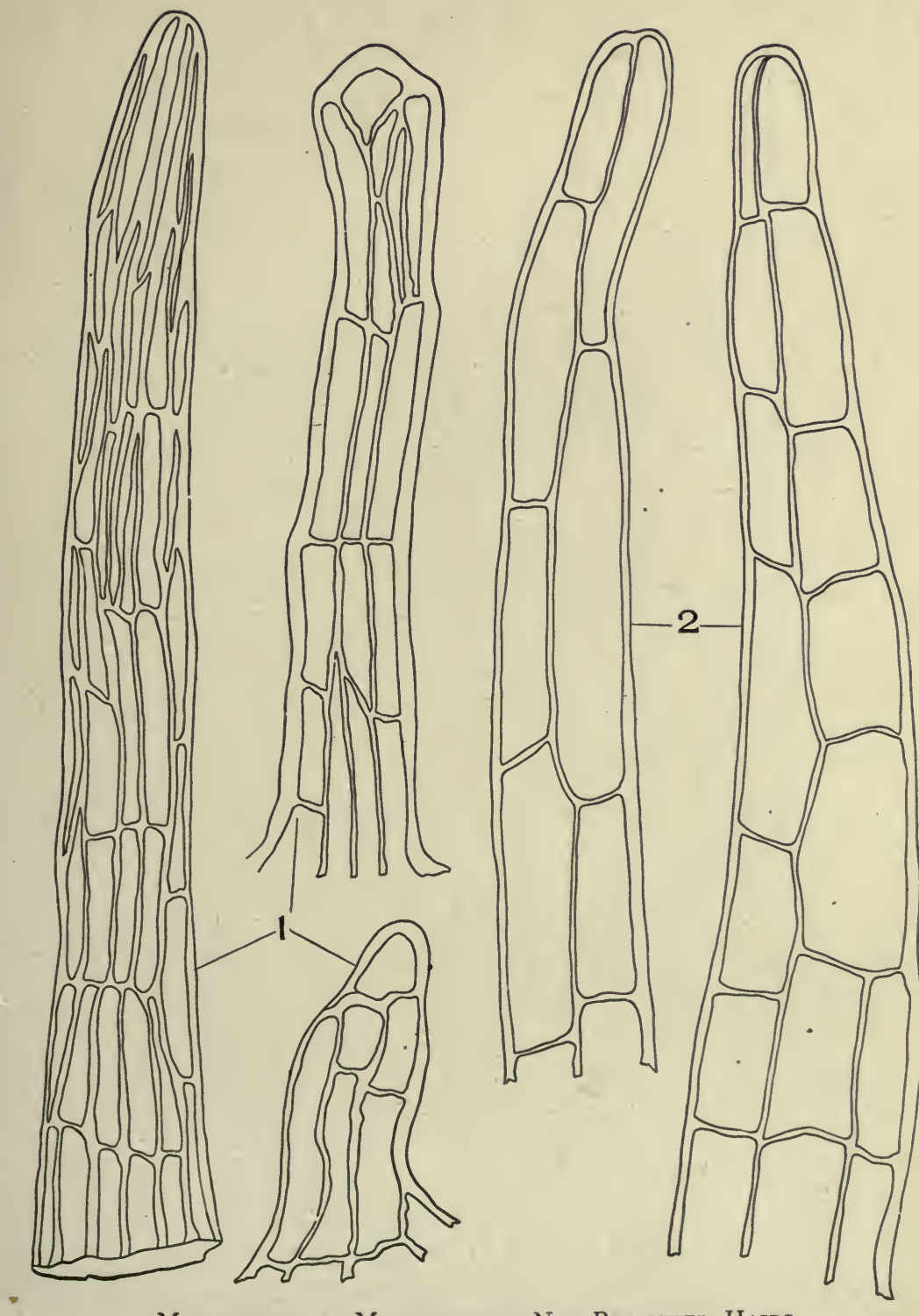

Multicellular Multiseriate Non-Branched Hairs

I. Cumin (Cuminum cyminum, L.).

2. Marigold (Calendula officinalis, L.). 


\section{PLATE II}
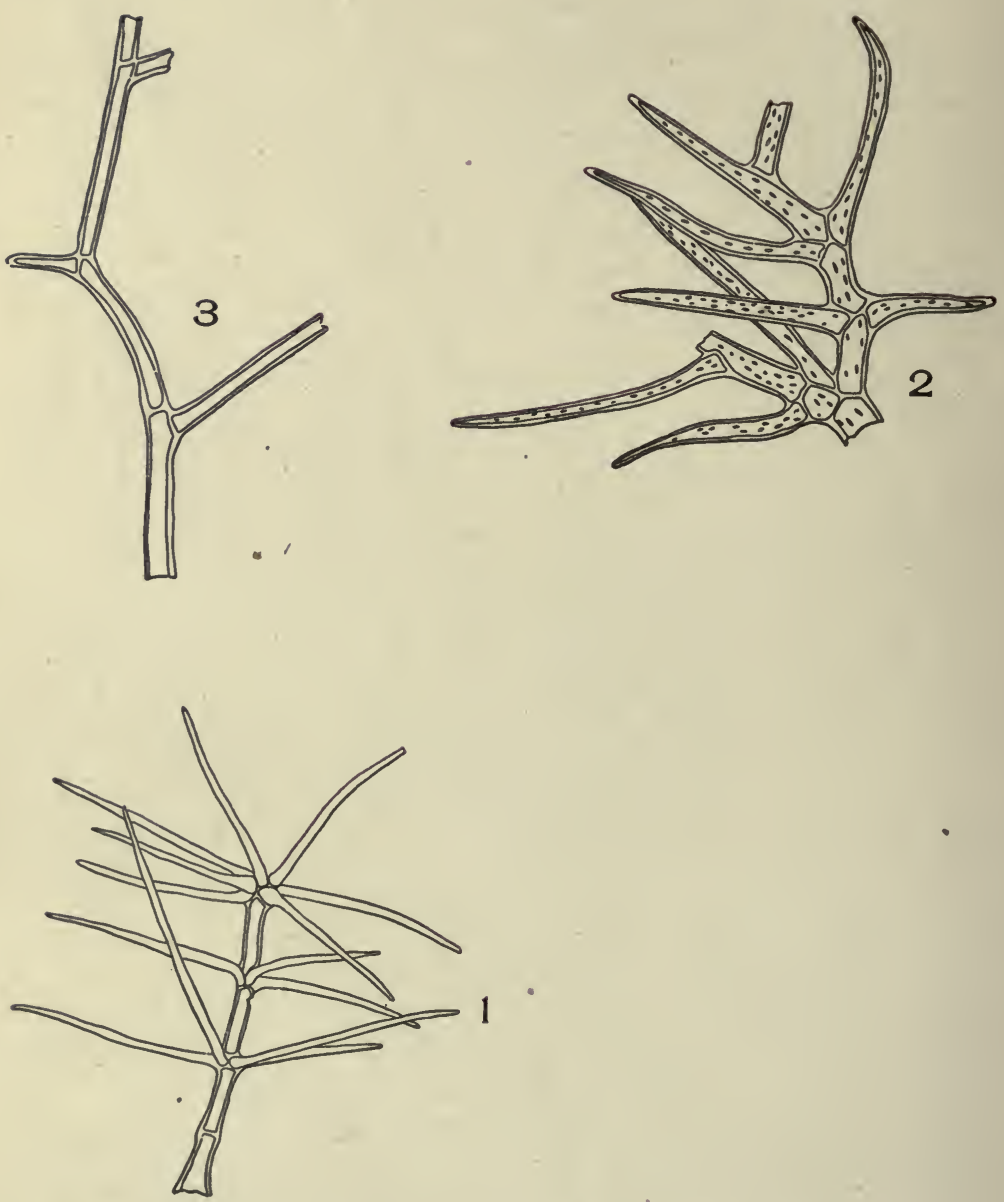

Multicellular Uniseriate Branched Hairs

I. Mullen leaf (Verbascum thapsus, L.).

2. Lavender flowers (Lavandula vera, D. C.).

3. Dittany of Crete (Origanum dictamnus, L.). 
branches, and the walls are rough. Thus the multicellular branched hairs may be divided into subgroups which have alternate, opposite, whorled, or in certain hairs irregularly arranged branches. Each class may be again subdivided according to color, character of cell termination, etc., as cited at the beginning of the chapter.

Occasionally multicellular hairs assume the form of a shield (Plate. I2, Fig. I); in such cases the hair is termed peltate, as in the non-glandular multicellular hair of shepherdia canadensis.

Hairs grow out from the surface of the epidermis in a perpendicular, a parallel, or in an oblique direction. Hairs which grow parallel or oblique to the surface are usually curved, ard the outer curved part of the wall is usually thicker than the inner curved wall.

The mature hairs of some plants consist of dead cells. In other plants the cells forming the hair are living. When dried, those hairs, which were dead before drying, contain air; while those hairs which were living before drying, show great variation in color and in the nature of the cell contents. The contents are either organic or inorganic. The commonest organic constituent is dried protoplasm. In cannabis indica are deposits of calcium carbonate.

Multicellular multiseriate branched hairs are the ultimate division of the pappus of erigeron, aromatic goldenrod, arnica, grindelia, boneset, and life-everlasting.

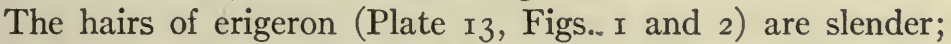
the walls are porous. Each hair terminates in two cells, which are greatly extended and sharp-pointed; the branches from the basal part of the hairs (Plate I3, Fig. I) are of about the same length as the apical branches.

The hairs of aromatic goldenrod (Plate 13, Figs. 3 and 4 ) are larger than those of erigeron; the diameter is greater and the walls are non-porous. The apex of the hair terminates in a group of about four cells of unequal length, which are sharppointed. The branches of the basal cells (Plate I3, Fig. 3) are similar to the branches of the apical cells.

The hairs of arnica (Plate 14, Figs. I and 2) have thick, strongly porous wails; the branches terminate in sharp points. The apex of the hair terminates in a single cell. The basal 
PLATE 12

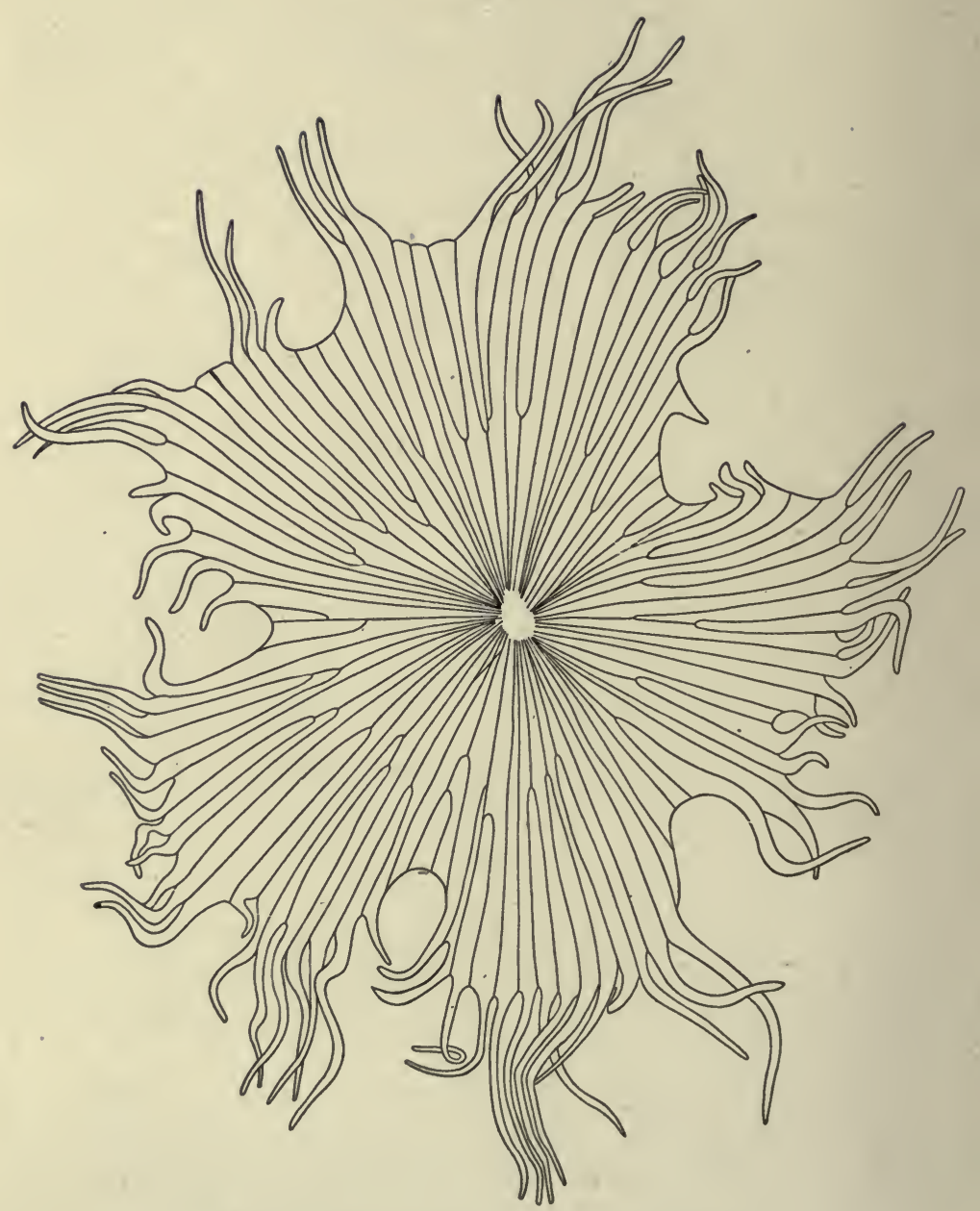

Non-Glandular Multicellular Hairs Shepherdia canadensis, [L.] Nutt. 


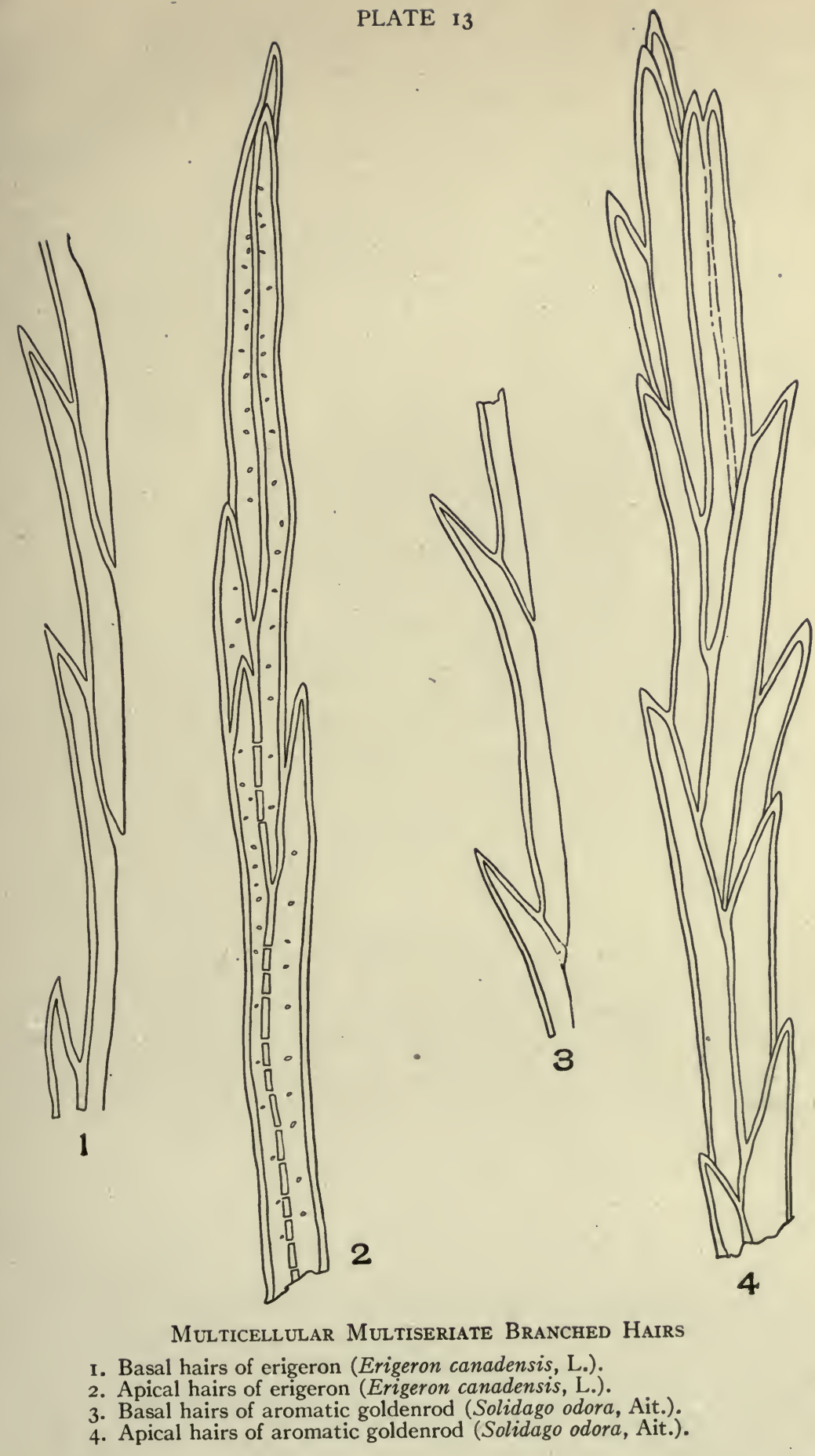


branches (Plate 14, Fig. 2) are much longer than special branches.

The hair of grindelia (Plate I4, Figs. 3 and 4 ) has very thick walls with numerous elongated pores. The apex of the hair terminates in a cluster of cells with short, free, sharp-pointed ends. The basal branches (Plate 14, Fig. 4) are longer than the apical branches.

Boneset hair (Plate I5, Figs. I and 2) has non-porous walls. The apex of the hair terminates in two blunt-pointed cells. The terminal wall is thicker than the side wall. Some of the branches lower down terminate in cells with very thick or solid points. The basal branches (Plate 15, Fig. I) are longer, but the cells are narrower and more strongly tapering than are the branches of the apical part of the hair.

Life-everlasting (Plate 15, Figs. 3 and 4) has uniformly thickened but non-porous walls. The hair terminates in two blunt-pointed, greatly elongated cells.

The basal branches (Plate I5, Fig. 4) are narrower, slightly tapering, and the base of the branches frequently curve downward.

The cell cavities of these hairs are filled with air.

The walls of hairs are composed of cutin, of lignin, and of cellulose.

\section{PERIDERM}

The periderm is the outer protective covering of the stems and roots of mature shrubs and trees. The periderm replaces the epidermis. The periderm may be composed of cork cells, stone cell-cork, or a mixture of cork, parenchyma, fibres, stone cells, etc.

\section{CORK PERIDERM}

The typical periderm is made up of cork cells. Cork cells vary in appearance, according to the part of the cell viewed.

On surface view (Plate I6, Fig. A) the cork cells are angled in outline and are made up of from four to seven side walls; five- and six-sided cells are more common than the four- and seven-sided cells. Surface sections of cork cells show their 

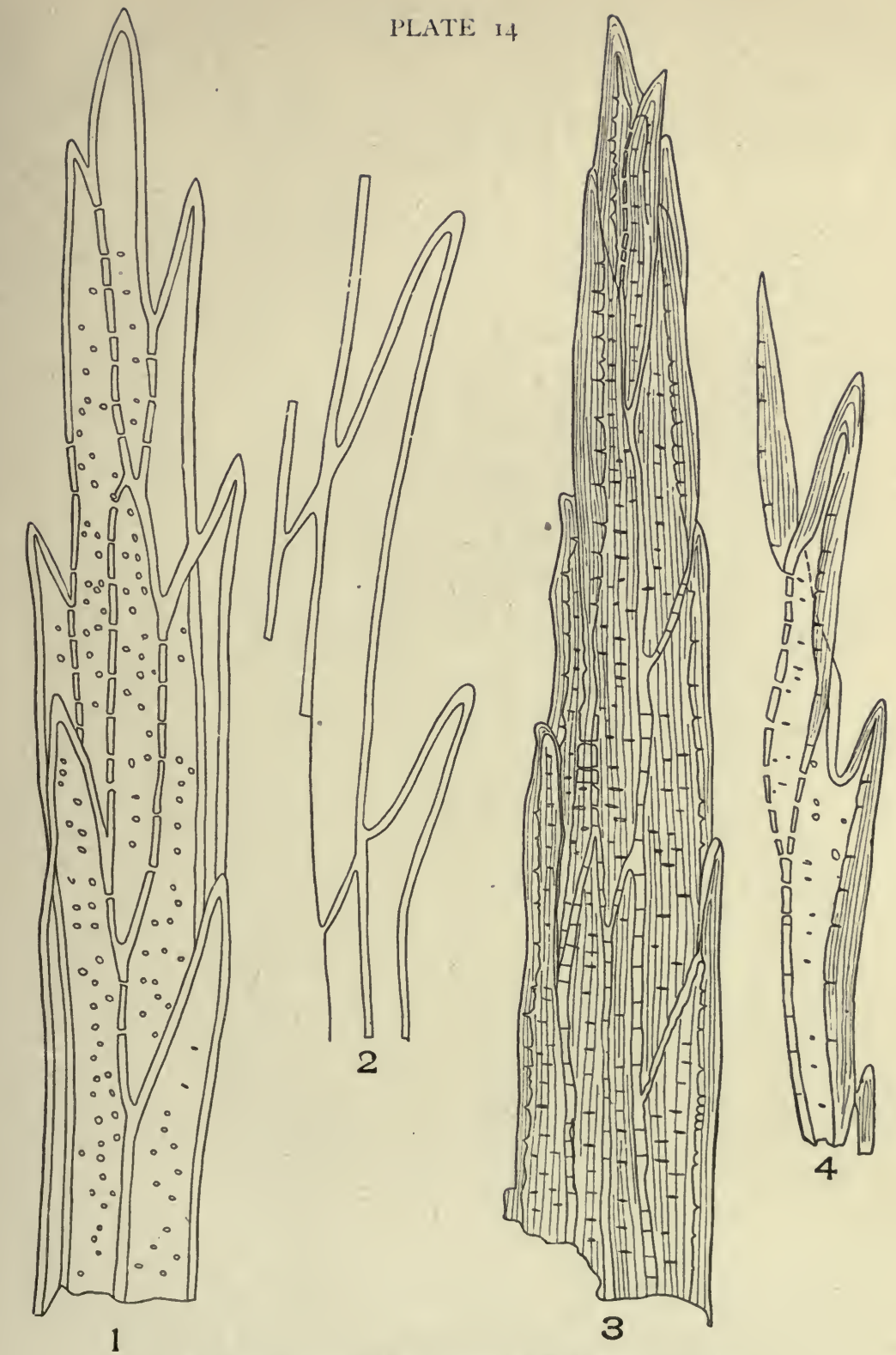

Multicellular Multiseriate Branched Hairs

I. Apical hairs arnica (Arnica montana, L.).

2. Basal hairs arnica (Arnica montana, L.).

3. Apical hairs grindelia (Grindelia squarrosa, [Pursh] Dunal).

4. Basal hairs grindelia (Grindelia squarrosa, [Pursh] Dunal). 


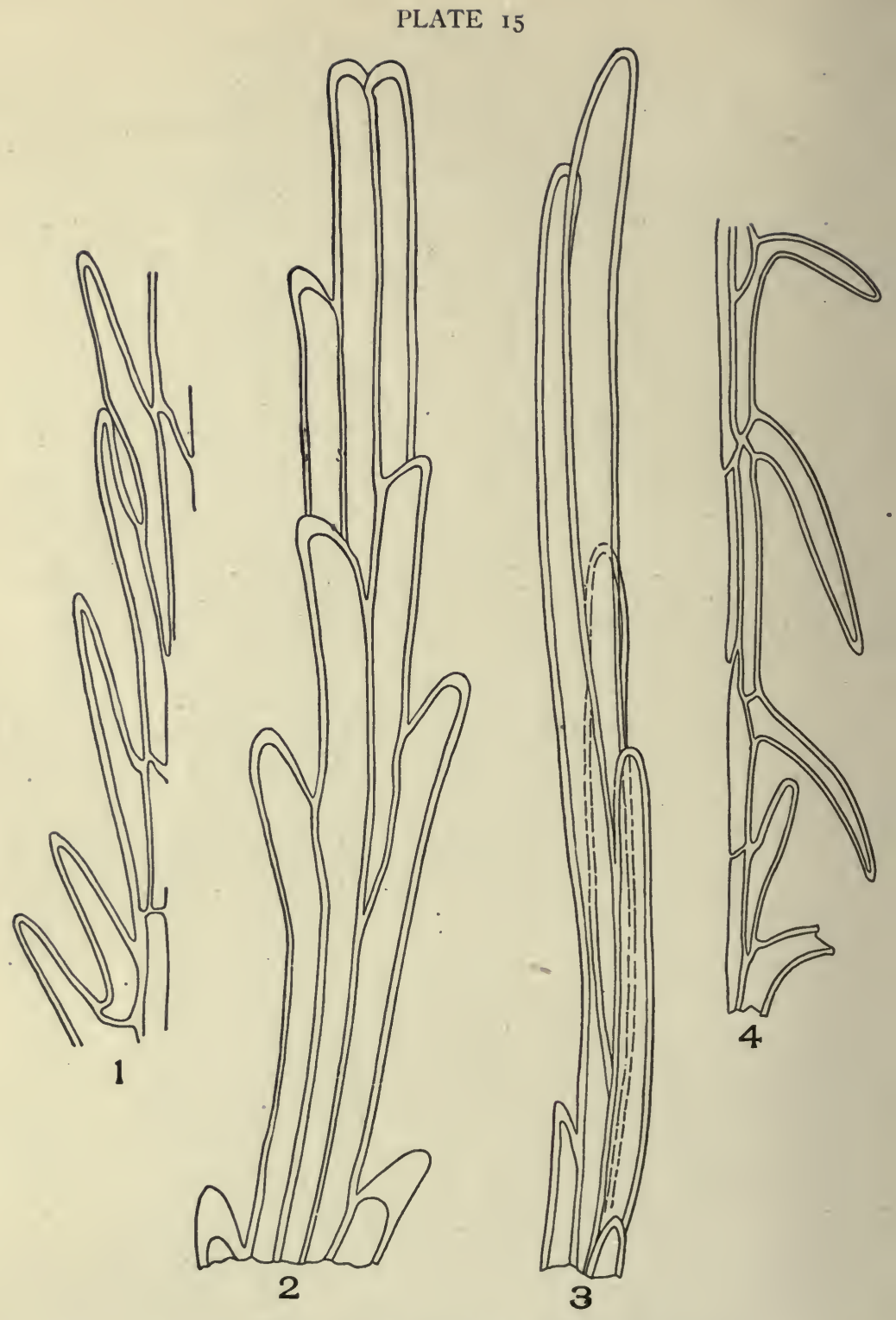

Multicellular Multiseriate Branched Hairs

I. Apical hairs boneset (Eupatorium perfoliatum, L.).

2. Basal hairs boneset (Eupatorium perfoliatum, L.).

3. Apical hairs life-everlasting (Gnaphalium obtusifolium, L.).

4. Basal hairs life-everlasting (Gnaphalium obtusifolium, L.). 
length and width. These side walls usually appear nearly white, while the end wall, particularly of the outermost cork cells, usually appears brown or reddish-brown, or in some cases nearly black.

Cork cells on cross-section are rectangular in form, and they are arranged in superimposed rows, the number of rows being gradually increased as the plant grows older. Such an increase in the number of rows of cork cells is shown in the cross-section of cascara sagrada (Plate I6, Fig. C).

Cork cells fit together so closely that there is no intercellular spaces between the cells. In this case two rows of cork cells occupy no greater space than the solitary row of cork cells immediately over and external to them. As a rule, the outermost layers of cork cells have a narrower radial diameter than the cork cells of the underlying layers. This is due to the fact that these outer cells are stretched as the stem increases in diameter. This view shows the height of cork cells, but not always the length, which will, of course, vary according to the part of the cell cut across. In a section a few millimeters in diameter, however, all the variations in size may be observed. The color of the walls is nearly white.

The cavity may contain tannin or other substances. When tannin is present, the cavity is of a brownish or brownish-red color, or it may be nearly black. Most barks appear devoid of any colored or colorless cell contents.

The radial section (Plate I6, Fig. B) of cork cells shows the height of the cells and the width of the cells at the point cut across. Some cells will be cut across their longest diameter, while others will be cut across their shortest diameter. Cork cells are, therefore, smaller in radial section than they are in cross-section. The color of the walls is white, and the color and nature of the cell contents vary for the same reasons that they vary in cross-sections.

The number of layers of cork cells occurring in cross- and radial-sections varies according to the age of the plant, to the type of plant, and to the conditions under which the plant is growing.

The number of layers of cork cells is not of diagnostic importance, nor is the surface view of cork cells diagnostic except in certain isolated cases. 


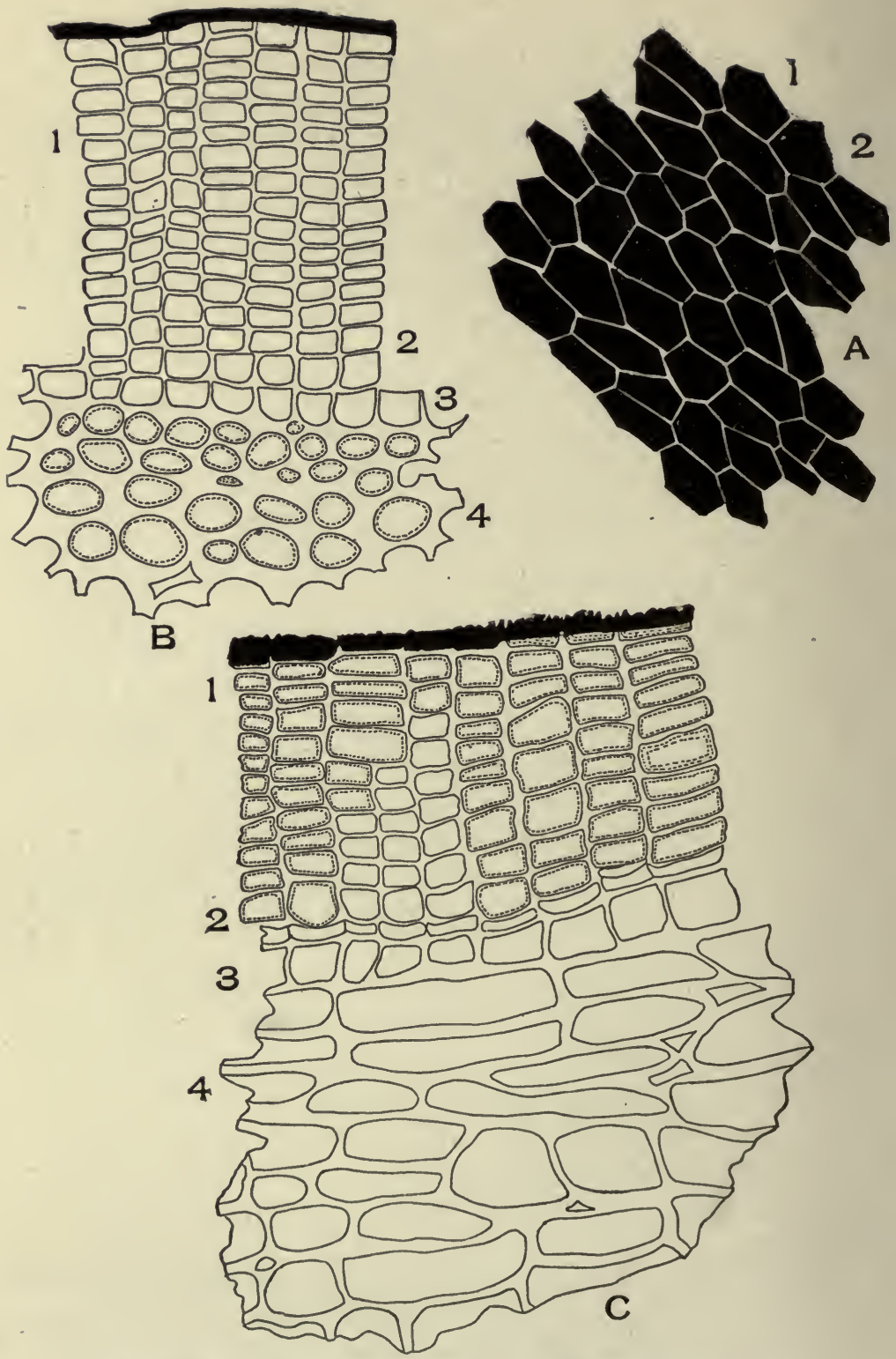

Periderm of Cascara Sagrada (Rhamnus purshiana, D.C.)

A. I, Outline of cork cells; 2, Line of contact of adjoining cork cells.

$B$. Radial longitudinal section of cascara sagrada. I, Cork cells; 2,Phellogen; 3, Forming parenchyma cells; 4, Cortical parenchyma cells.

C. Cross-section of cascara sagrada. I, Cork cells; 2, Phellogen; 3, Forming parenchyma cells; 4 , Cortical parenchyma cells. 
The presence or absence of cork or epidermal tissue in powders must always be noted. The presence of cork enables one to distinguish Spanish from Russian licorice. In like manner, the presence of epidermis enables one to distinguish the pharmacopœial from the unofficial peeled calamus. The absence of epidermis in Jamaica ginger is one of the means by which this variety is distinguished from the other varieties of ginger, etc.

In canella alba the periderm is replaced by stone cell-cork. That is, the cells forming the periderm are of a typical cork shape, but the walls are lignified, unequally thickened, and the inner or thicker walls are strongly porous, and the walls are of a yellowish color. Stone cell-cork forms the periderm of clove bark also, but the cells are narrower and longer, and the inner wall is not so thick or porous as is the case in canella alba bark.

\section{STONE CELL PERIDERM}

In canella alba (Plate $\mathrm{I} 7$, Fig. B) cork periderm is frequently replaced by stone cells, particularly in the older barks. These stone cells form the periderm because they replace the cork periderm, which fissures and scales off as the root increases in diameter.

The side and end walls of cork cells are of nearly uniform diameter. Exceptions occur, but they are not common. In buchu stem (Plate I0I, Fig. 3), the cork cells have thick outer walls, but thin sides and inner walls. The cell cavity contains reddish-brown deposits of tannin.

\section{PARENCHYMA AND STONE CELL PERIDERM}

As the trees and shrubs increase in diameter, cracks or fissures occur in the periderm, or corky layer. In such cases the phellogen cells divide and redivide in such manner as to cut off a portion of the parenchyma cells, stone cells, and fibres of the cortex which is inside of and below the fissure. All the parenchyma cells, etc., exterior to the newly formed cork cells soon lose their living-cell contents, since their food-supply is cut off by the impervious walls of the cork cells. In time they are forced outward by the developing cork cells until they 


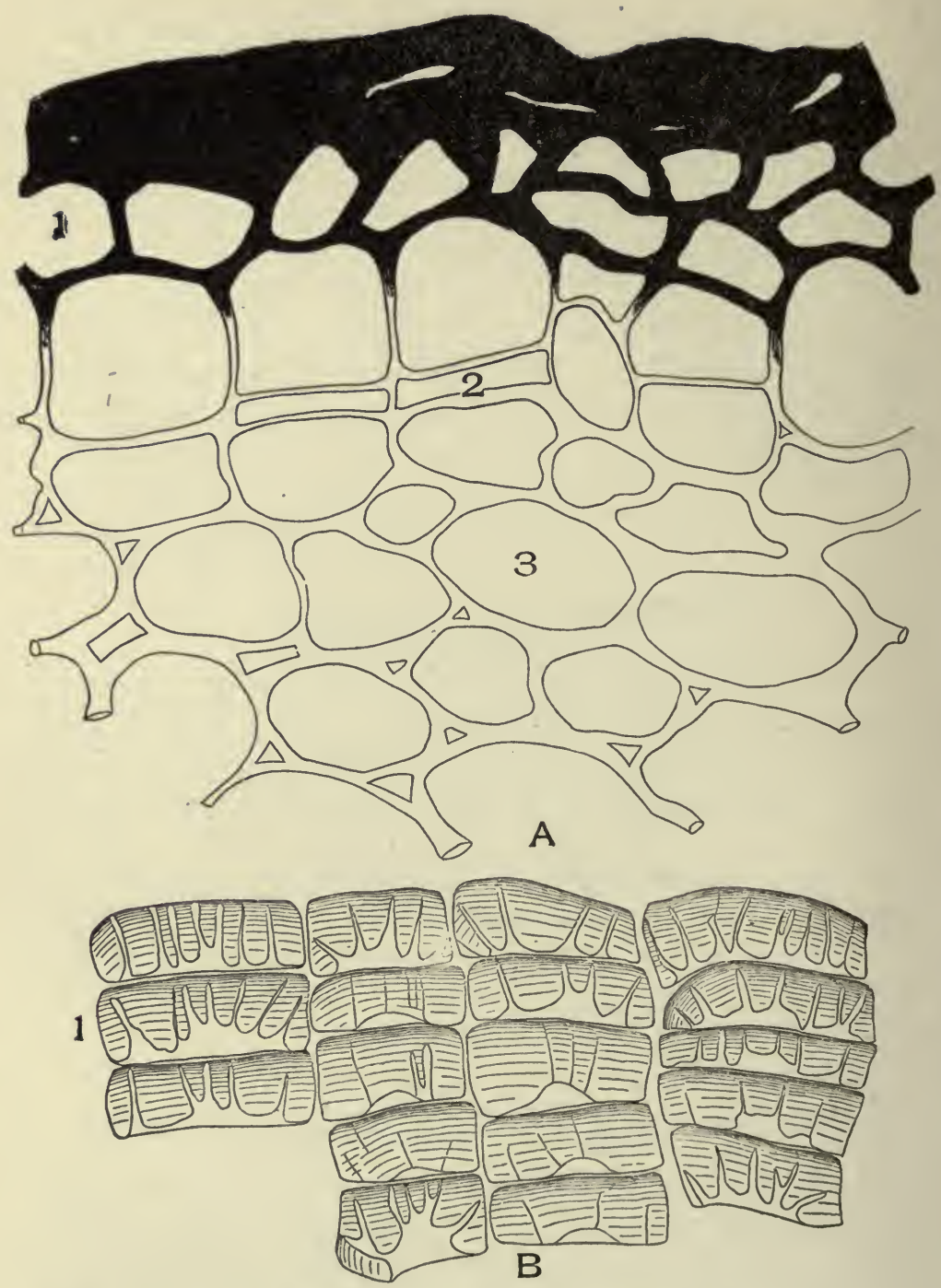

A. Cross-section of Mandrake Rhizome (Podophyllum peltatum, L.).

I. Epidermis.

2. Phellogen.

3. Cortical parenchyma.

B. Stone cell periderm of white cinnamon (Canella alba, Murr.). 
PLATE 18

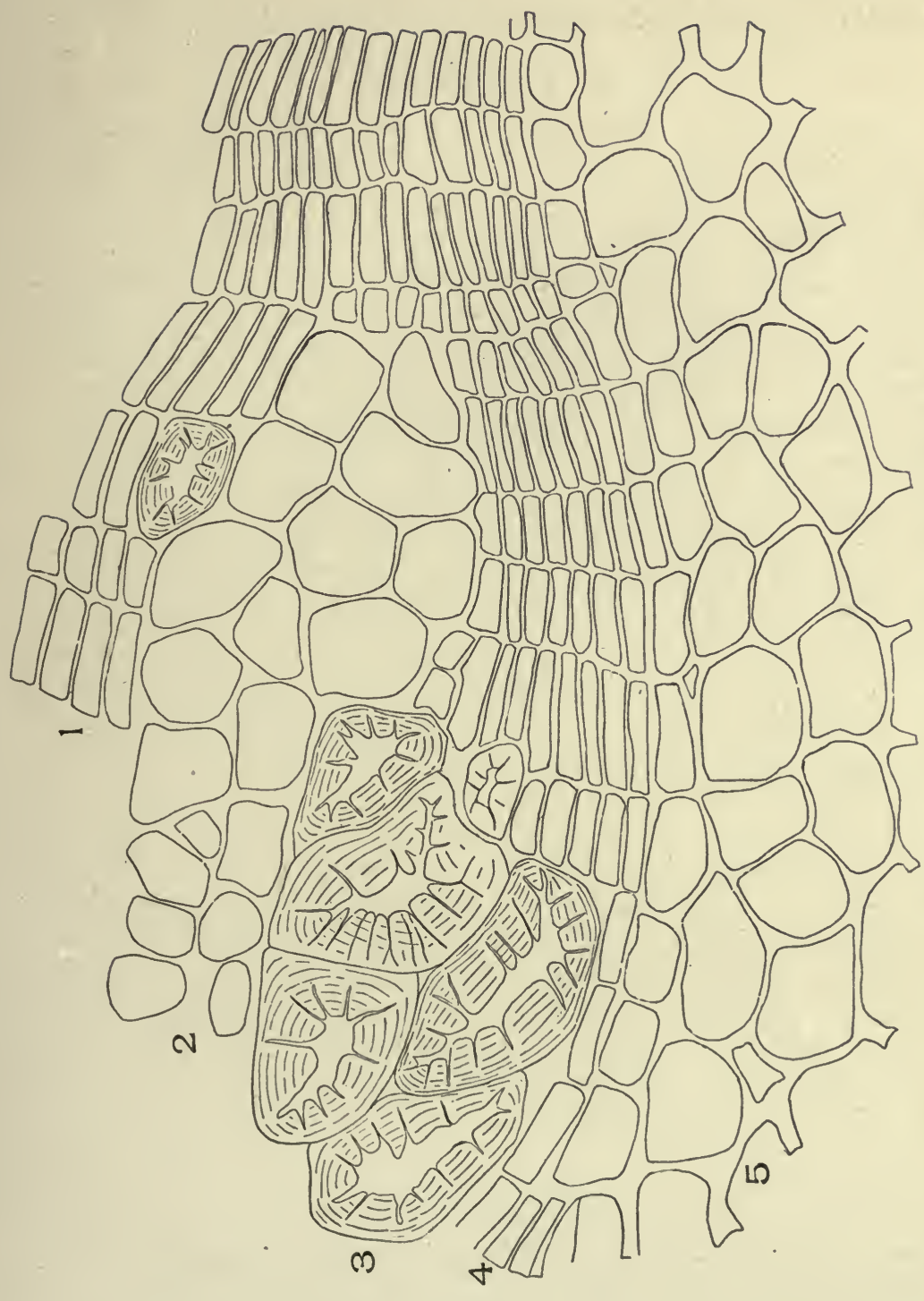

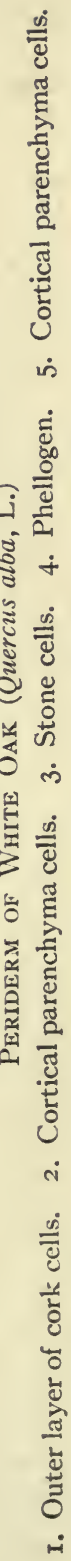


partially or completely fill the break in the periderm. In white oak bark (Plate I8), as in other barks, a large part of the periderm is composed of dead and discolored cortical cells.

\section{ORIGIN OF CORK CELLS}

The cork cells are formed by the meristimatic phellogen cells, which originate from cortical parenchyma. These cells divide into two cells, the outer changing into a cork cell, while the inner cell remains meristimatic. In other instances the outer cell remains meristimatic, while the inner cell changes into a cortical parenchyma cell. The development of a cortical parenchyma cell from a divided phellogen cell is shown in Plate IOr, Fig. 6. Both the primary and secondary cork cells originate from the phellogen or cork cambrium layer. Cork cells do not contain living-cell contents; in fact, in the majority of medicinal barks the cork cells contain only air.

The walls of typical cork cells are composed, at least in part, of suberin, a substance which is impervious to water and gases. -In certain cases layers of cellulose, lignin, and suberin have been identified. Suberin, however, is present in all cork cells, and in some cases all of the walls of cork cells are composed of suberin.

Suberized cork cells are colored yellow with strong sodium hydroxide solutions and by chlorzinciodide. 


\section{CHAPTER III}

\section{MECHANICAL TISSUES}

The mechanical tissues of the plant form the framework around which the plant body is built up. These tissues are constructed and placed in such a manner in the different organs of the plant as to meet the mechanical needs of the organ. Many underground stems and roots which are subjected to radial pressure have the hypodermal and endodermal cells arranged in the form of a non-compressible cylinder. Such an arrangement is seen in sarsaparilla root (Plate 38, Fig. 4). The mechanical tissue of the stem is arranged in the form of solid or hollow columns in order to sustain the enormous weight of the branches. In roots the mechanical tissue is combined in ropelike strands, thereby effectively resisting pulling stresses. The epidermis of leaves subjected to the tearing force of the wind has epidermal cells with greatly thickened walls, particularly at the margin of the leaf. The epidermal cells of most seeds have very thick and lignified cell walls, which effectively resist crushing forces.

The cells forming mechanical tissues are: bast fibres, wood fibres, collenchyma cells, stone cells, testa epidermal cells, and hypodermal and endodermal cells of certain plants. The walls of the cells forming mechanical tissues are thick and lignified, with the exception of the collenchyma cells and a few of the fibres. Lignified cells are as resistive to pulling and other stresses as similar sized fragments of steel. The hardness of their wall and their resistance to crushing explain the fact that they usually retain their form in powdered drugs and foods.

\section{BAST FIBRES}

One of the most important characters to be kept in mind in studying bast fibres is the structure of the wall. In fact, the author's classification of bast fibres is based largely on wall 
structure. Such a classification is logical and accurate, because it is based upon permanent characters. Another character used in classifying bast fibres is the nature of the cell, whether branched or non-branched. In fact, this latter character is used to separate all bast fibres into two fundamental groups-namely, branched bast fibres and non-branched bast fibres. The third important character utilized in classifying fibres is the presence or absence of crystals.

Bast fibres are classified as follows:

I. Crystal bearing.

2. Non-crystal bearing.

The crystal-bearing fibres are divided into two classes:

I. Of leaves.

2. Of barks.

The non-crystal bearing are divided into:

I. Branched.

2. Non-branched.

The branched and non-branched are divided into four classes:

I. Non-porous and non-striated.

2. Porous and non-striated.

3. Striated and non-porous.

4. Porous and striated.

CRYSTAL-BEARING BAST FIBRES

The crystal-bearing fibres are composed (I) of groups of fibres, (2) of crystal cells, and (3) of crystals. In these cases the groups of fibres are large, and they are frequently completely covered by crystal cells, which may or may not contain a crystal. The crystals found on the fibres from the different plants vary considerably in size and form. As a rule, the fibres when separated are free of crystal cells and crystals. This is so because the crystal cells are exterior to the fibres, and in separating the fibres during the milling process the crystal cells are broken down and removed from the fibres. It is common, therefore, to find isolated fibres and crystals associated with the crystal-bearing fibres. The fibres which are crystal-bearing may be striated or porous, etc.; but owing to the fact that the grouping of the fibres and crystals is so characteristic, little or no attention is paid to the structure of the individual fibres. 

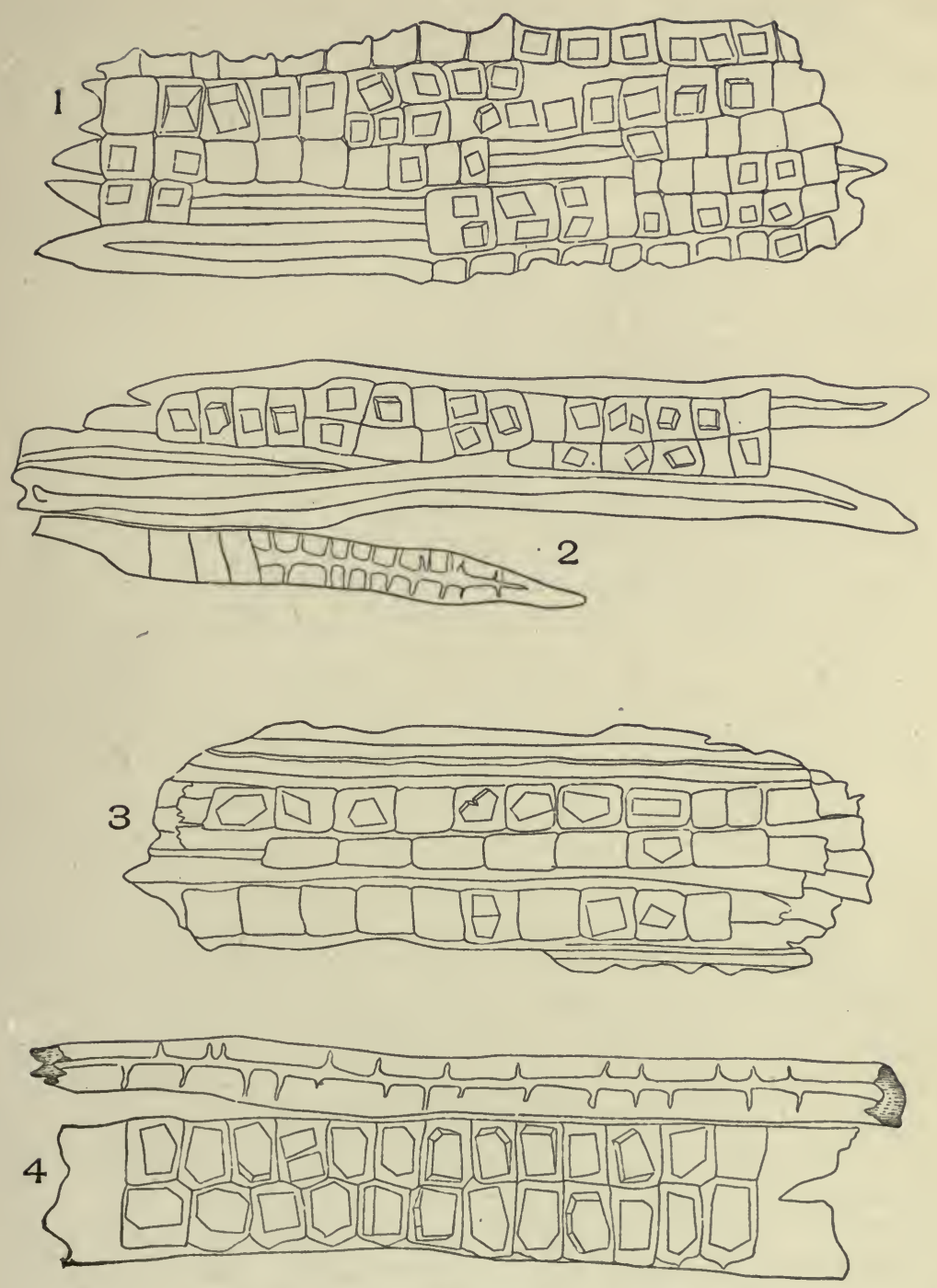

Crystal-Bearing Fibres of Barks

I. Frangula (Rhamnus frangula, L.).

2. Cascara sagrada (Rhamnus purshiana, D.C.).

3. Spanish licorice (Glycyrrhiza glabra, L.).

4. Witch-hazel bark (IIamamelis virginiana, L.). 
Crystal-bearing fibres occur in the barks of frangula (Plate I9, Fig. I); cascara sagrada (Plate I9, Fig. 2); witch-hazel (Plate 19, Fig. 4); in cocillana (Plate 20, Fig. I); in white oak (Plate 20, Fig. 2); in quebracho (Plate 20, Fig. 3); and in Spanish licorice root (Plate I9, Fig. 3).

The crystal-bearing fibres of leaves are always associated with vessels or tracheids and with cells with chlorophyl. The presence or absence of crystal-bearing fibres in. leaves should always be noted. The crystal-bearing fibres of leaves are composed of fragments of conducting cells, fibres, crystal cells, and crystals. The crystal-bearing fibres of leaves occur in larger fragments than the other parts of the leaf, because the fibres are more resistant to powdering. Having observed that a leaf has crystal-bearing fibres, in order to identify the powder it is necessary to locate one of the other diagnostic elements of the leaf -as the papillæ of coca (Plate 2I, Fig. I), or the hair of senna (Plate 2I, Fig. 3), or the vessels in eucalyptus (Plate 2I, Fig. 2).

Branched bast fibres occur in only a few of the medicinal plants, notable examples being tonga root and sassafras root. Occasionally one is found in mezereum bark.

The bast fibre of tonga root (Plate 22, Fig. 2) often has seven branches, but four- and five-branched forms are more common. The walls are non-porous, non-striated, and nearly white.

The bast fibre of sassafras (Plate 22, Fig. I) has thick, nonporous, and non-striated walls, and the branching occurs usually at one end only of the fibre. Most of the bast fibres of sassafras root are non-branched.

\section{POROUS AND STRIATED BAST FIBRES}

Porous and striated walled bast fibres occur in blackberry bark of root, wild-cherry bark, and in cinchona bark.

The fibres of blackberry root bark (Plate 23, Fig. I) have distinctly porous and striated walls; the cavity, which is usually greater than the diameter of the wall, contains starch. These fibres usually occur as fragments.

In wild-cherry bark (Plate 23, Fig. 2) the fibre has short, thick, unequally thickened walls, which are porous and striated. Most of the fibres are unbroken. 


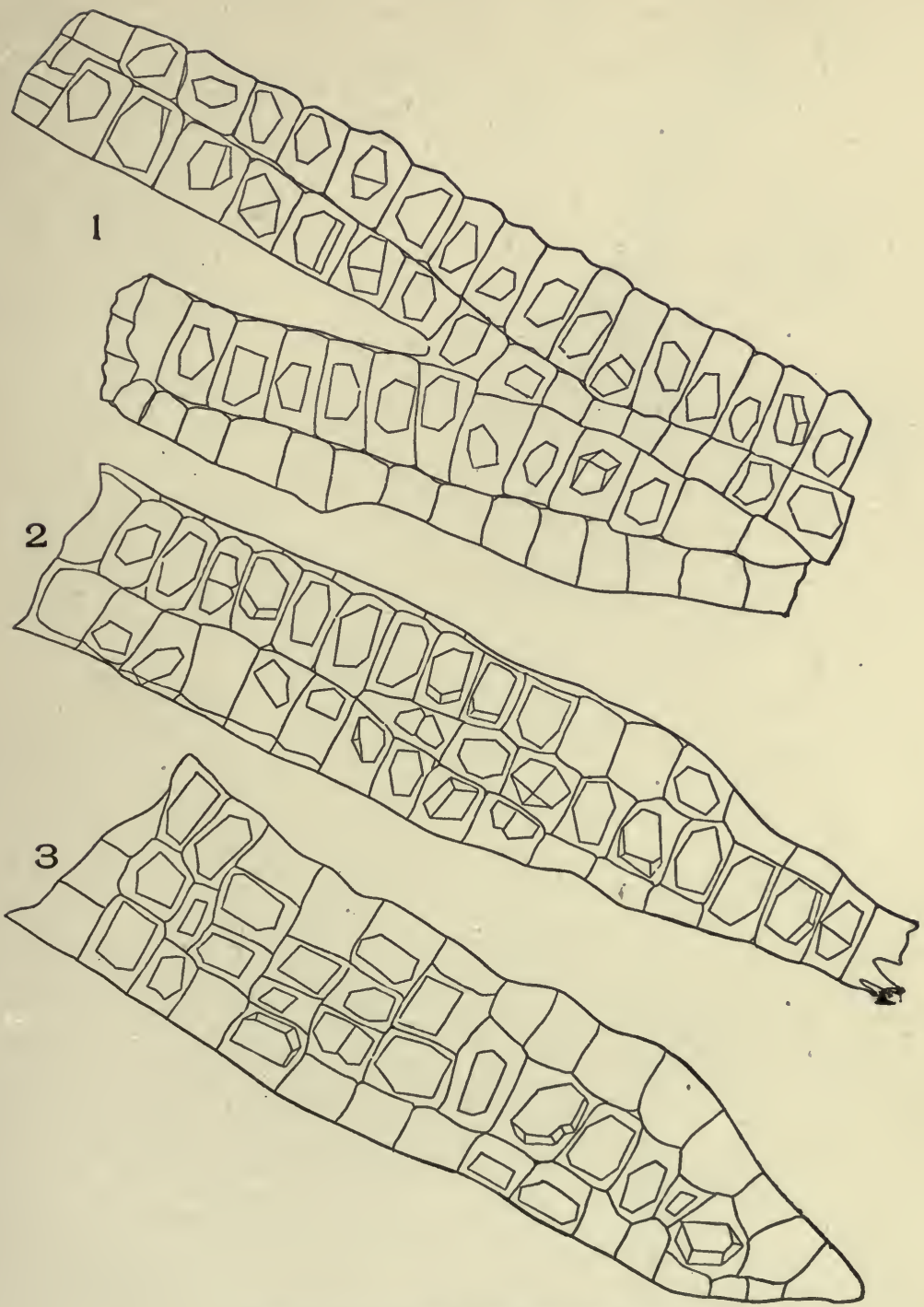

Crystal-Bearing Fibres of Barks

I. Cocillana (Guarea rusbyi, [Britton] Rusby).

2. White oak (Quercus alba, L.).

3. Quebracho (Aspidosperma quebracho-blanco, Schlechtendal). 
PLATE 2I

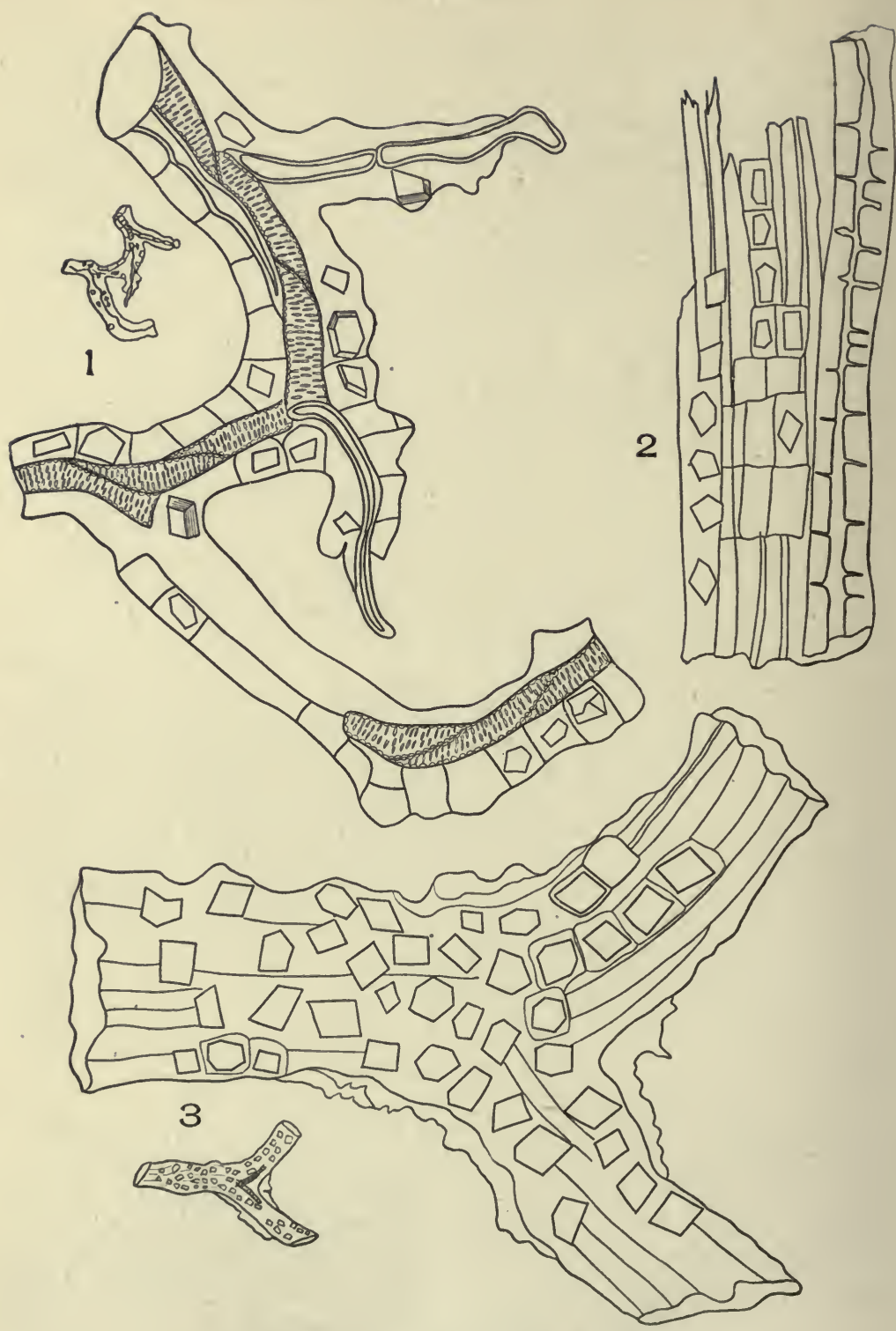

Crystal-Bearing Fibres of Leaves

1. Coca leaf (Erythroxylon coca, Lam.).

2. Eucalyptus leaf (Eucalyptus globulus, Labill).

3. Senna leaf (Cassia angustifolia, Vahl.). 
PLATE 22

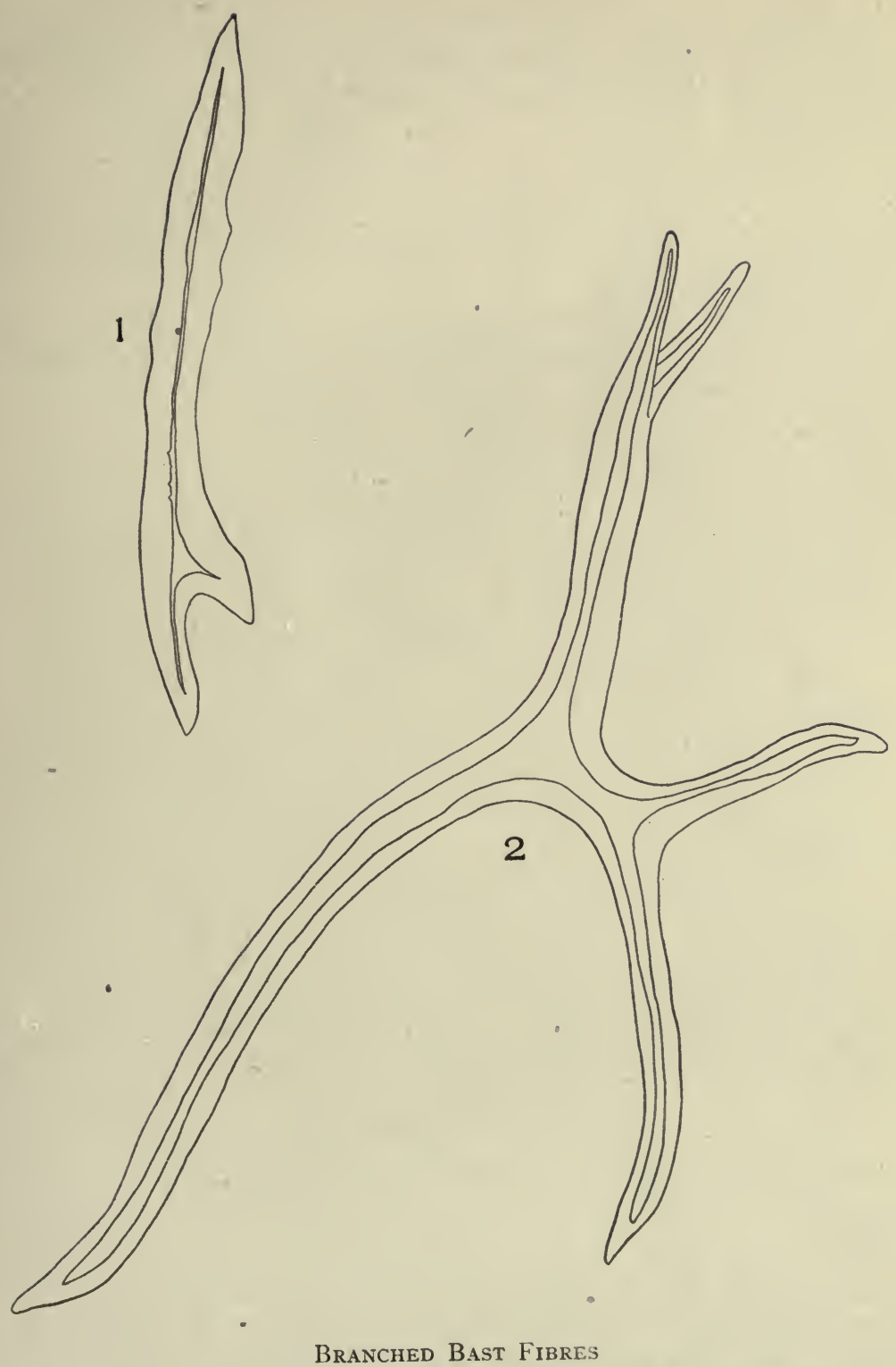

I. Sassafras root bark (Sassafras variifolium, [Salisb.] Kuntze).

2. Tonga root. 
Yellow cinchona bark (Plate 23, Fig. 3) has very thick, prominently striated porous-walled fibres, with either blunt or pointed ends. The cavity is narrow, and the pores are simple or branched.

\section{POROUS AND NON-STRIATED BAST FIBRES}

Porous and non-striated bast fibres occur in marshmallow root and echinacea root.

The fibres of marshmallow (Plate 24, Fig. 3) usually occur in fragments. The walls have simple pores, and the diameter of the cell cavity is very wide; the pores on the upper or lower wall are circular or oval in outline (end view).

The bast fibres of echinacea root (Plate 24, Fig. 4) are seldom broken; the walls are yellow, the pores are simple and numerous. The edges and surface of the fibres are frequently covered with a black intercellular substance.

\section{NON-POROUS AND STRIATED BAST FIBRES}

Non-porous and striated bast fibres occur in elm bark, stillingia root, and cundurango bark. The bast fibres of elm bark (Plate 25, Fig. I) occur in broken, curved, or twisted fragments. The central cavity is very small, and the walls are longitudinally striated.

In powdered stillingia root (Plate 25, Fig. 2) the bast fibres are broken, and the wall is very thick and longitudinally striated. The central cavity is small and usually not visible. Bast fibres of cundurango (Plate 25, Fig. 3) are broken in the powder. The cavity is very narrow, and the striations are arranged spirally, less frequently transversely.

\section{NON-POROUS AND NON-STRIATED BAST FIBRES}

Non-porous and non-striated walled bast fibres occur in mezereum bark, in Ceylon cinnamon, in sassafras root bark, and in soap bark.

The simplest non-porous and non-striated walled bast fibres are found in mezereum bark (Plate 26, Fig. 4). The individual fibre is very long. If often measures over three millimeters in length, so that in the powder the fibre is usually broken. The wall is non-lignified, white, non-porous, and of uniform diameter. 
PLATE 23

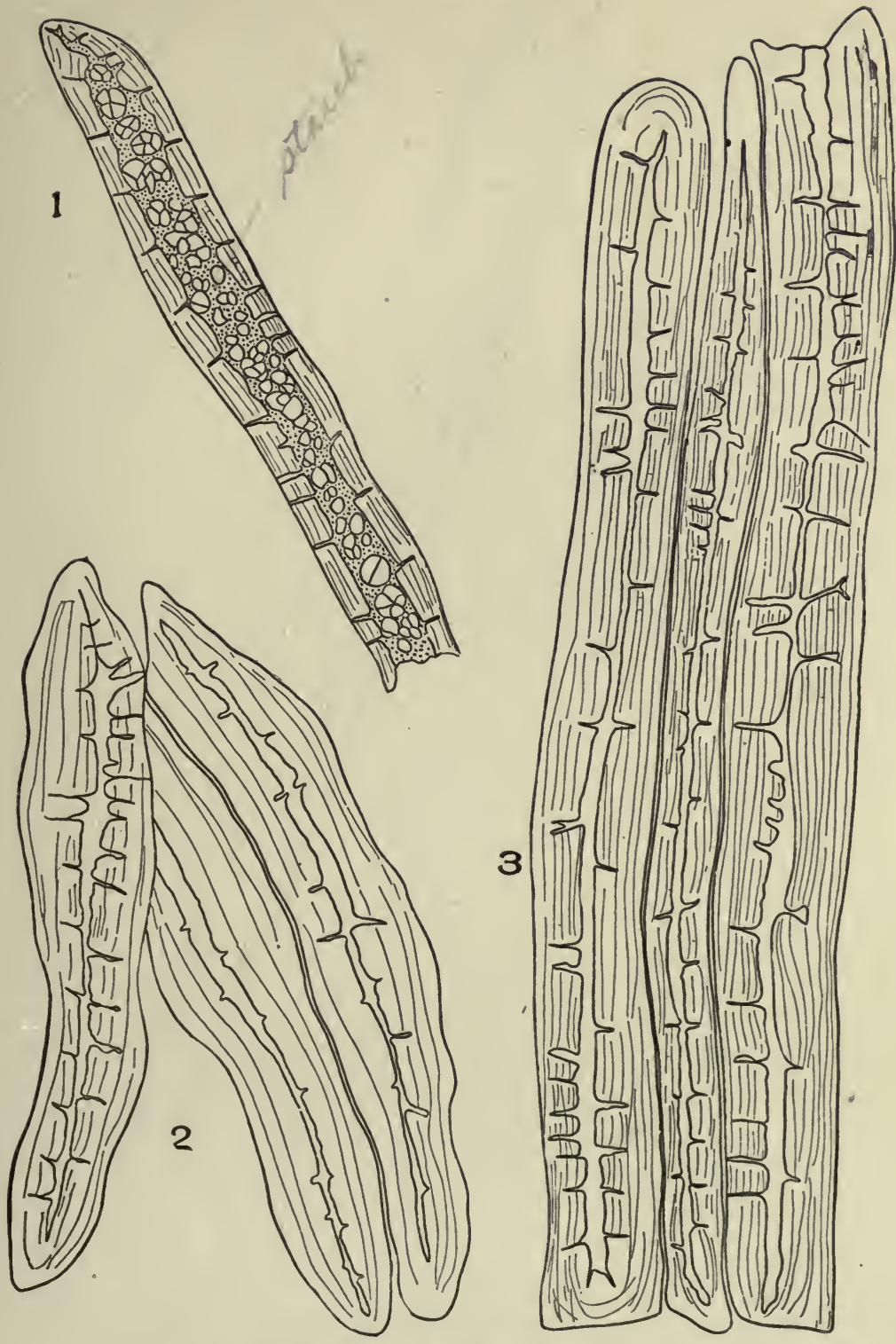

Porous and Striated Bast Fibres

I. Blackberry root (Rubus cuneifolius, Pursh.).

2. Wild cherry (Prunus serotina, Ehrh.).

3. Yellow cinchona (Cinchona species). 


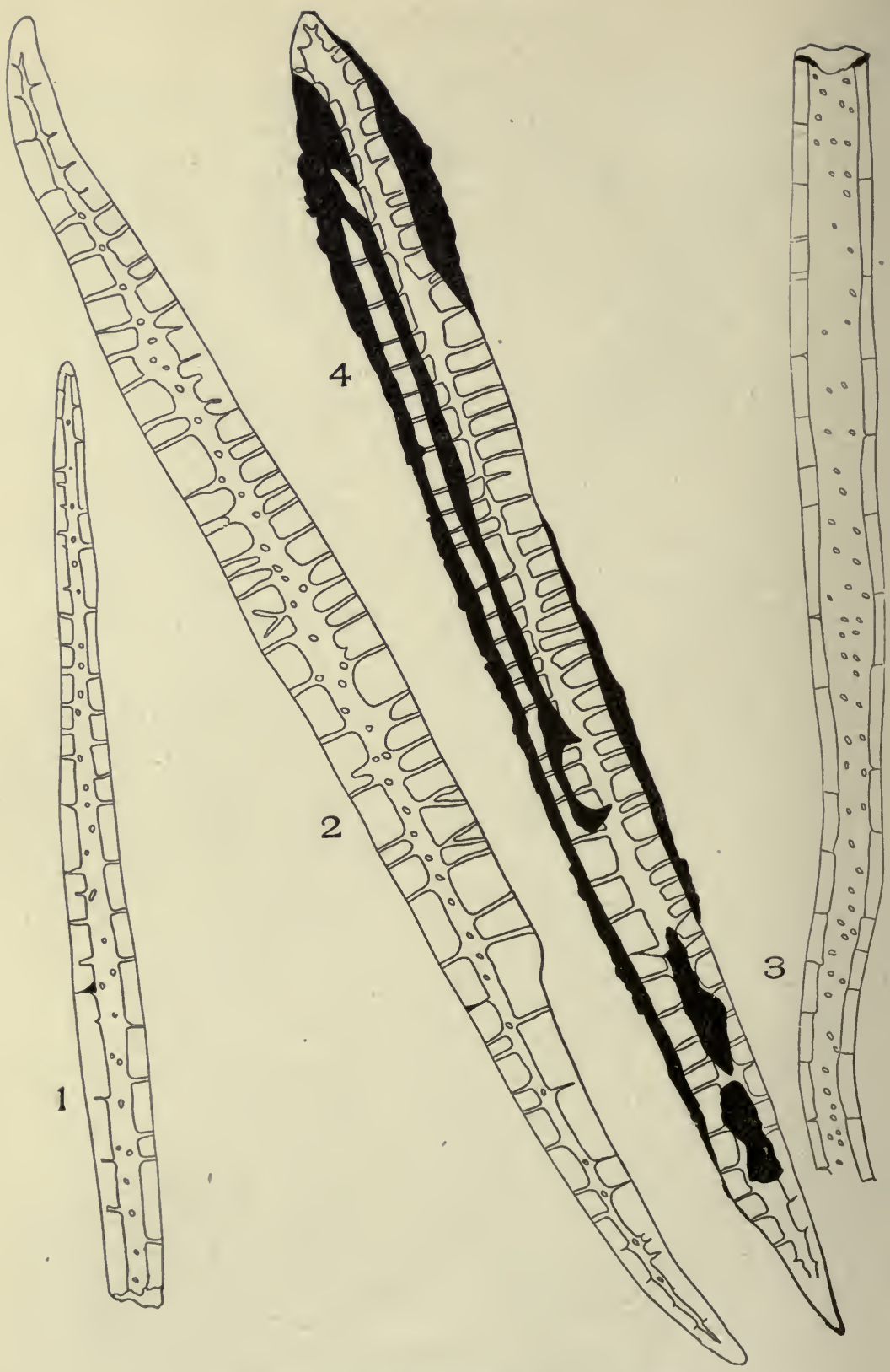

Porous aNd Non-Striated Bast Fibres

I. Sarsaparilla root (Hypoderm), (Smilax officinalis, Kunth).

2. Unicorn root (Endoderm).

- 3. Marshmallow root (Althaea officinalis, I..).

4. Echinacea root (Echinacea angustifolia, D, C.), 
PLATE 25

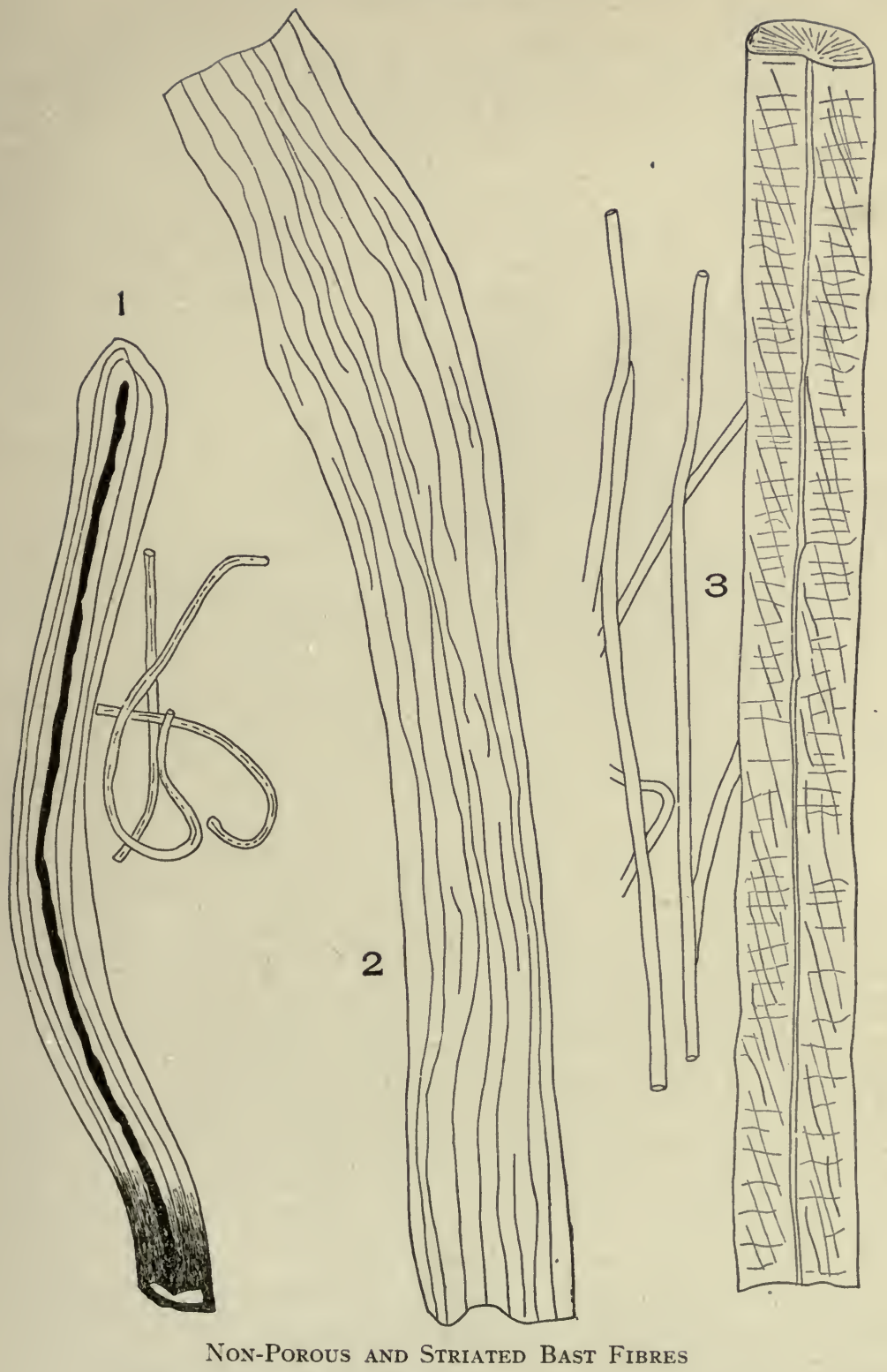

I. Elm bark (Ulmus fulva, Michaux).

2. Stillingia root (Stillingia sylvatica, L.).

3. Cundurango root bark (Marsdenia cundurango, [Triana] Nichols). 
In Ceylon cinnamon (Plate 26, Fig. 2) the bast fibres measure up to $.900 \mathrm{~mm}$. in length, so that in powdering the bark the fibre is rarely broken. These bast fibres, unlike the bast fibres of mezereum, have thick, white walls and a narrow cell cavity. Both ends of the fibre taper gradually to a long, narrow point.

In Saigon cinnamon the bast fibres are not as numerous as they are in Ceylon cinnamon. The individual fibres are thicker than in Ceylon cinnamon, and the walls are yellowish and rough and the ends bluntly pointed. These fibres are rarely ever free from adhering fragments of parenchyma tissue.

In sassafras root bark (Plate 26, Fig. 3) the fibre has one nearly straight side - the side in contact with the other bast fibres - and an outer side with a wavy outline, caused by the fibre's pressing against parenchyma cells, the point of highest elevation being the point of the fibre's growth into the intercellular space between two cells. The outer part of the wall tapers gradually at either end to a sharp point. The walls are white, thick, and non-porous.

In soap bark (Plate 26, Fig. I) the bast fibres have thick, white, wavy walls and a narrow cavity. One end of the cell is frequently somewhat blunt while the opposite end is slightly tapering.

The branched stone cells of wild-cherry bark have three or more branches. The pores are small and usually non-branched, and the striations are very fine and difficult to see unless the iris diaphragm is nearly closed. The central cavity is very narrow and frequently contains brown tannin.

The branched stone cells of hemlock bark are very large; the walls are white and distinctly porous bordering on the cell cavity, which contains bright reddish-brown masses of tannin.

In cross-section bast fibres occur singly or isolated, as in Saigon cinnamon (Plate 34, Fig. I); or in groups, as in menispermum (Plate 27, Figs. I and 2); or in the form of continuous bands, as in buchu stem (Plate Ioo, Fig. 5).

Bast fibres are seen in longitudinal view in powdered arugs. The cell cavity shows throughout the length of the fibre. This cavity differs greatly in different fibres. In soap bark (Plate 26 , Fig. I) there is scarcely any cell cavity, while in mezereum bark (Plate 26, Fig. 4) the cell cavity is very large. 
PLATE 26

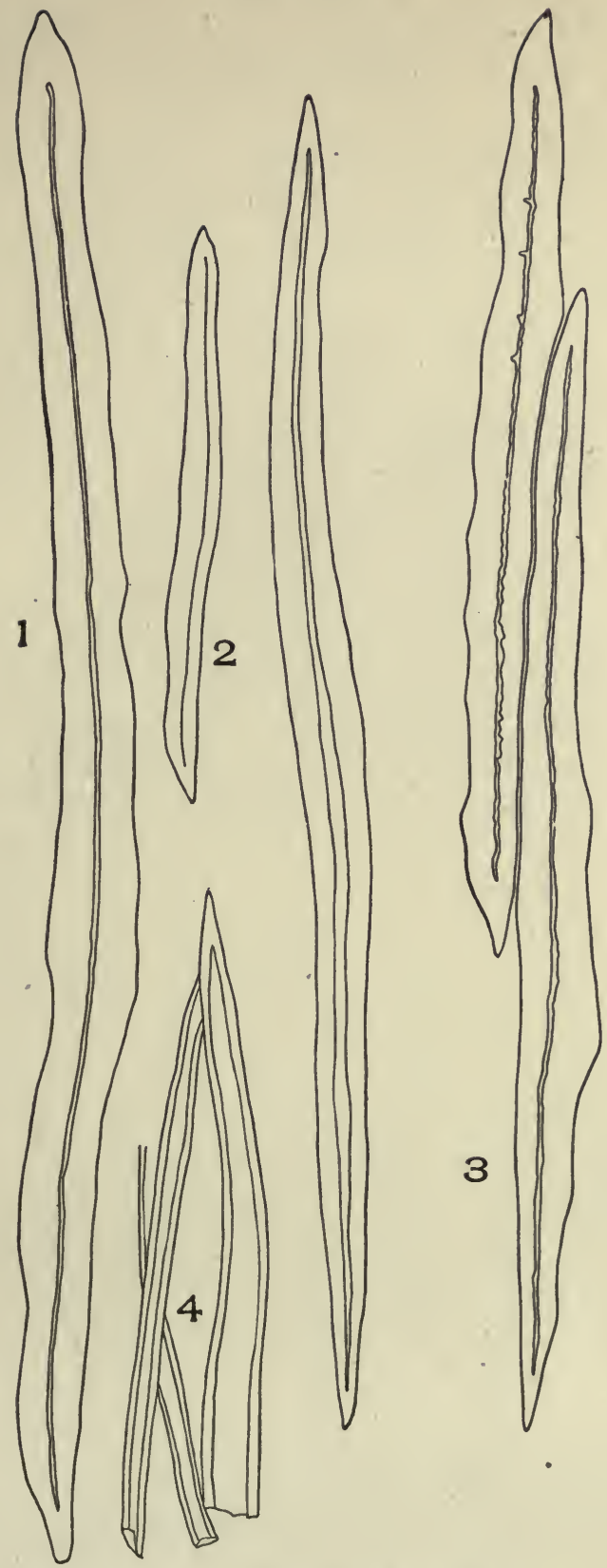

Non-Porous and Non-Striated Bast Fibres

I. Soap bark (Quillaja saponaria, Molina).

2. Ceylon cinnamon bark (Cinnamomum zeylanicum, Nees).

3. Sassafras root bark (Sassafras variifolium, [Salisb.] Kuntze).

1. Mezereum bark (Daphne mezereum, L.). 


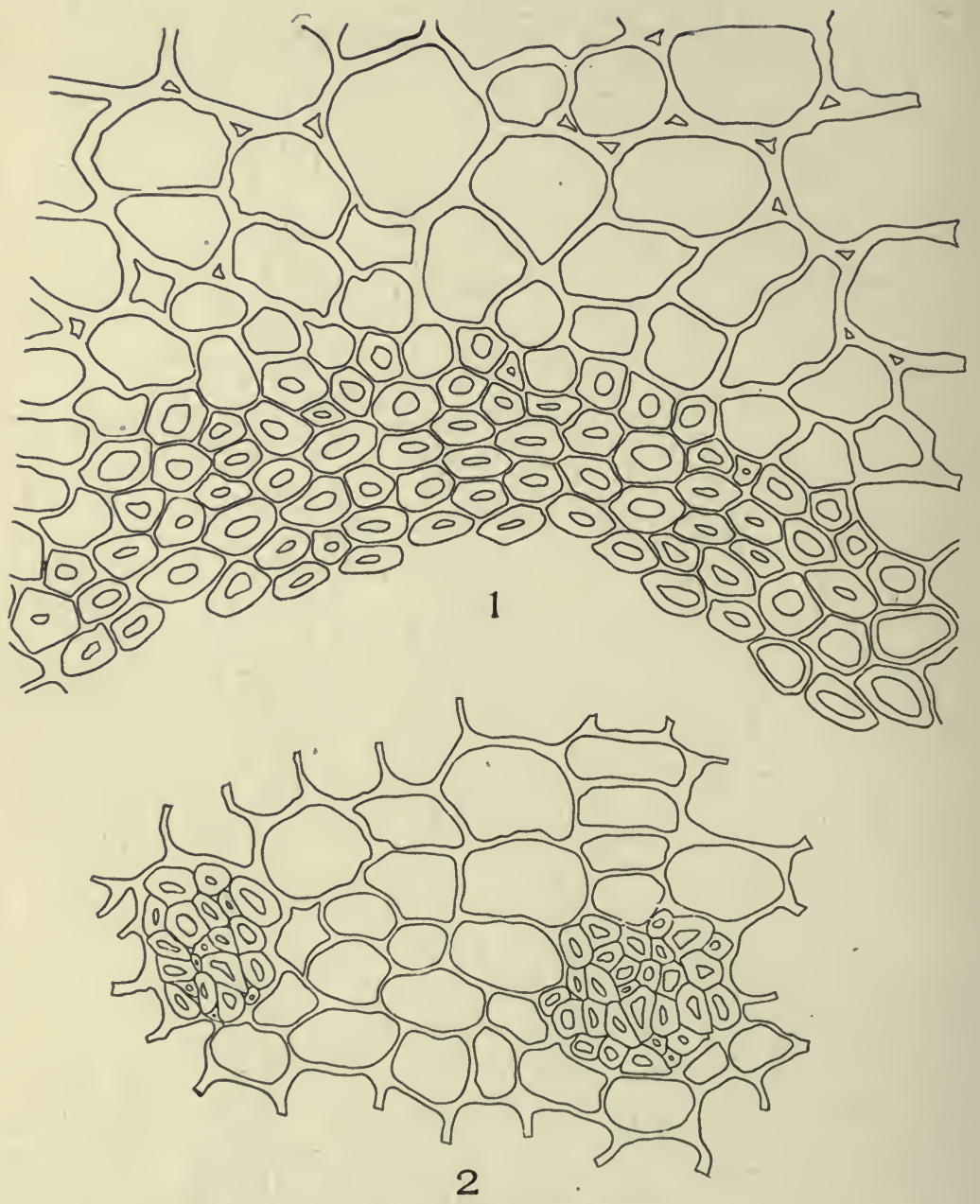

Groups of Bast Fibres

I. Menispermum rhizome (Menispermum canadensis, L.).

2. Althea root (Althea officinalis, L.) showing two groups of bast fibres. 
The pores, which are absent in many drugs, are, when present, either simple, as in echinacea root (Plate 24, Fig. 4), or they are branched, as in yellow cinchona (Plate 23, Fig. 3).

In each of the above fibres the length and width of the fibre are shown. The fibres also have pores of variable length. Such a variation is common to most fibres with pores. That part of the wall immediately over or below the cell cavity shows the end view or diameter of the pore, as in the fibre of marshmallow root (Plate 24, Fig. 3). As a rule, however, the pores show indistinctly on the upper and lower wall.

\section{OCCURRENCE IN POWDERED DRUGS}

In powdered drugs bast fibres occur singly or in groups. The individual fibres may be broken, as in mezereum and elm bark, or they may be entire, as in Ceylon cinnamon and in sassafras bark (Plate 26, Figs. 2 and 3 ).

The lignified walls of bast fibres are colored red by a solution of phlorogucin and hydrochloric acid, and the walls are stained yellow by aniline chloride.

In fact, few of the fibres found in individual plants occur in a broken condition.

Isolated bast fibres are circular in outline. Bast fibres, when forming part of a bundle, have angled outlines when they are completely surrounded by other bast fibres; but when they occur on the outer part of the bundle, and when in contact with parenchyma or other cortical cells, they are partly angled and partly undulated in outline.

In the bast fibres the pores are placed at right angles to the length of the fibre. The side walls show the length of the pore (Plate 24, Fig. 3); while the upper or lower wall shows the outline, which is circular, and the pore, which is very minute.

Most bast fibres have no cell contents. In some cases, however, starch occurs, as in the bast fibres of rubus.

The color of the bast fibres varies, being colorless, as in Ceylon cinnamon; or yellowish-white, as in echinacea; or bright yellow, as in bayberry bark.

Bast fibres retain their living-cell contents until fully developed; then they die and function largely in a mechanical way. 
The walls of bast fibres are composed of cellulose or of lignin. Most of the bast fibres occurring in the medicinal plants give a strong lignin reaction.

\section{WOOD FIBRES}

Wood fibres always occur in cross-sections associated with vessels and wood parenchyma, from which they are distinguished by their thicker walls, smaller diameter, and by the nature of the pores, which are usually oblique and fewer in number than the pores in the walls of wood parenchyma, and different in form from the pores of vessels.

The wood fibre on cross-section (Plate 105, Fig. 4) shows an angled outline, except in the case of the fibres bordering the pith-parenchyma, etc., in which case they are rounded on their outer surface, but angled at the points in contact with other fibres. The pore of wood fibres is one of the main characteristics which enable one to distinguish the wood fibres from bast fibres.

The pores are slanting or strongly oblique (Plate 28, Fig. 2), and they show for their entire length on the broadest part of the wall-i.e., the upper or the lower surface - while in the side wall they are oblique; but they are not so distinct as they are on the broad part of the wall.

Frequently the pores appear crossed when the upper and the lower wall are in focus, because the pores are spirally arranged, and the pore on the under wall throws a shadow across the pore on the upper wall, or vice versa.

Wood fibres always occur in a broken condition (Plate 28 , Fig. I) in powdered drugs. These broken fibres usually occur both singly and in groups in a given powder.

The color of wood fibres varies greatly in the different medicinal woods. Fragments of wood are usually adhering to witch-hazel, black haw, and other medicinal barks. In each of these cases the wood fibres are nearly colorless. In barberry bark adhering fragments of wood and the individual fibres are greenish-yellow. The wood fibres of santalum album are whitishbrown; of quassia, whitish-yellow; of logwood and santalum rubum, red.

Some wood fibres function as storage cells. In quassia the 
PLATE 28
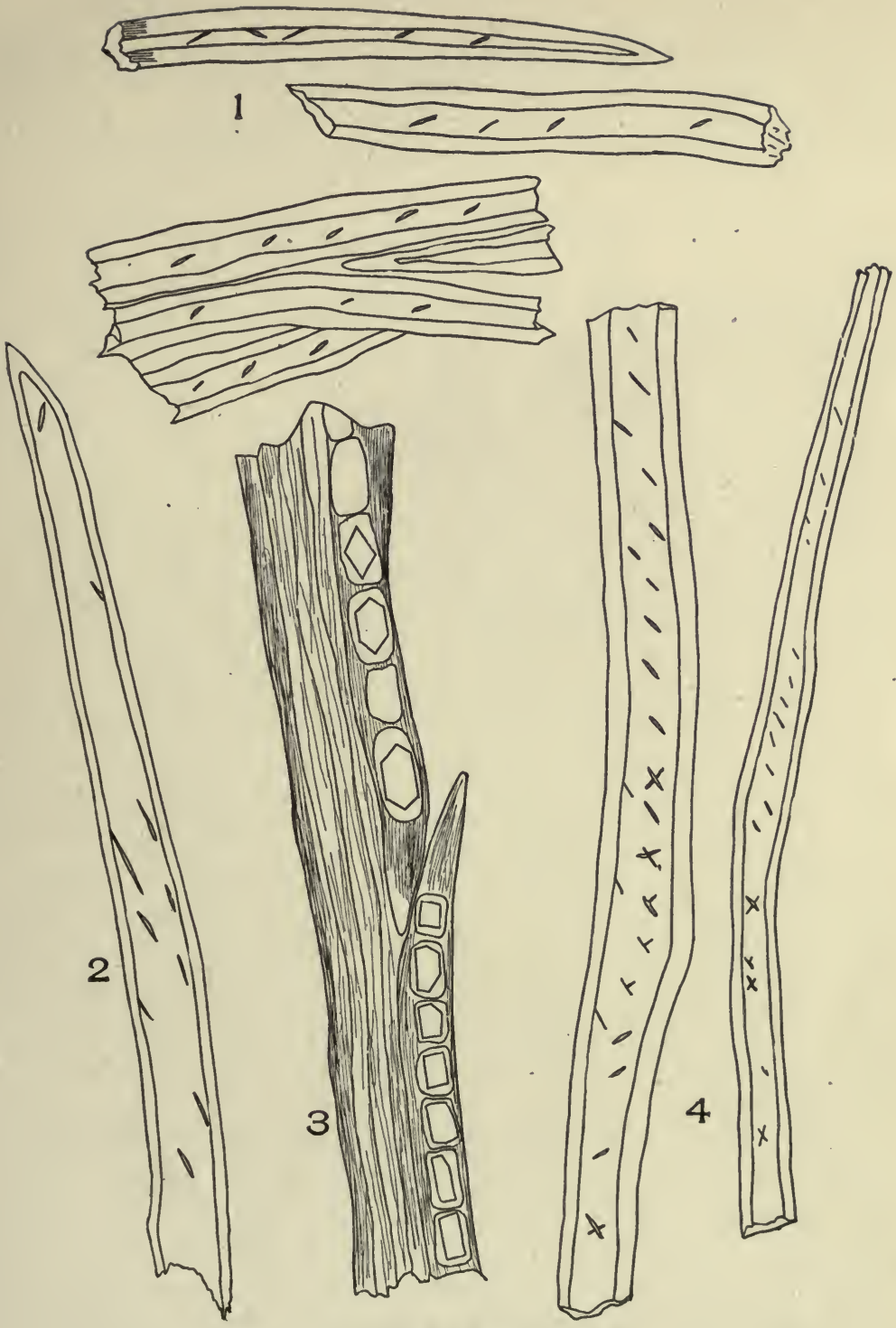

WoOd Fibres

I. White sandalwood (Santalum album, L.).

2. Quassia wood (Picrena excelsa, [Swartz] Lindl.).

3. Logwood with crystals (Hamatoxylon campechianum, L.).

4. Black haw root (Viburnum prunifolium, L.). 
wood fibres frequently contain storage starch. The wood fibres of logwood and red saunders contain coloring substances, which are partially in the cell cavity and partially in the cell wall.

The walls of wood are composed largely of lignin.

\section{COLLENCHYMA CELLS}

Collenchyma cells form the principal medicinal tissue of stems of herbs, petioles of leaves, etc. In certain herbs the collenchyma forms several of the outer layers of the cortex of the stem. In motherwort, horehound, and in catnip the collenchyma cells occur chiefly at the angles of the stem. In motherwort (Plate 29, Fig. B) there are twelve bundles, one large bundle at each of the four angles, and two small bundles, one on either side of the large bundle. In catnip (Plate 29, Fig. A) there are four large masses, one at each angle of the stem.

Collenchyma cells differ from parenchyma cells in a number of ways: first, the cell cavity is smaller; secondly, the walls are thicker, the greater amount of thickening being at the angles of the cells-that is, the part of the cell wall which is opposite the usual intercellular space of parenchyma cells, while the wall common to two adjoining cells usually remains unthickened. In horehound stem (Plate 30, Fig. 2) the thickening is so great at the angles that no intercellular space remains. In the side column of motherwort stem (Plate 30, Fig. I) the thickening between the cells has taken place to such an extent that the cell cavities become greatly separated and arranged in parallel concentric rows.

The collenchyma of the outer angle of motherwort stem (Plate 30, Fig. 3) is greatly thickened at the angles. There are no intercellular spaces between the cells, and cell cavity is usually angled in outline instead of circular, as in the cells of horehound. In certain plants intercellular spaces occur between the cells, and the walls are striated instead of being nonstriated, as in the stems of horehound, motherwort, and catnip.

Collenchyma cells retain their living contents at maturity. Many collenchyma cells, particularly of the outer layers of 
PLATE 29
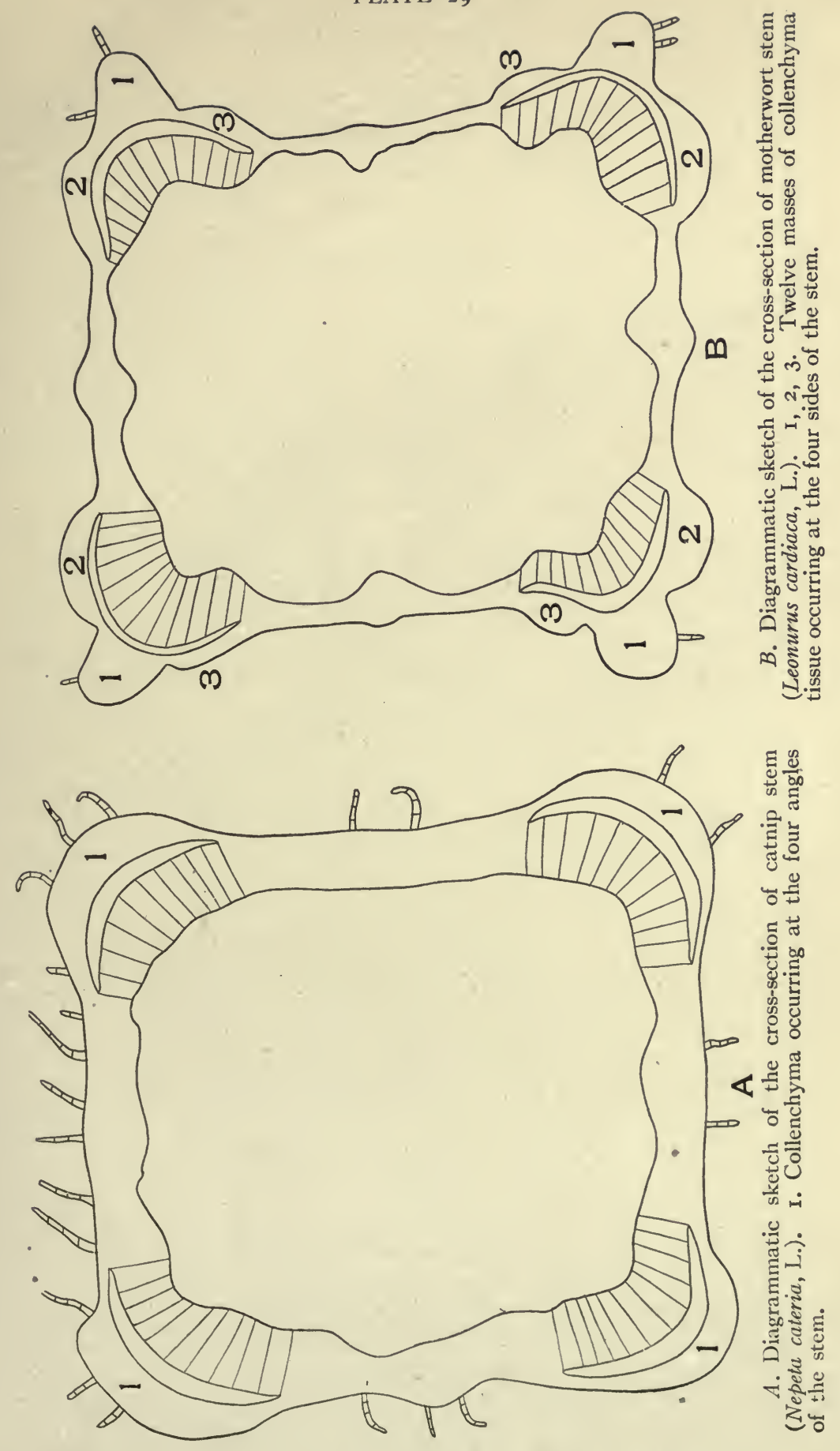

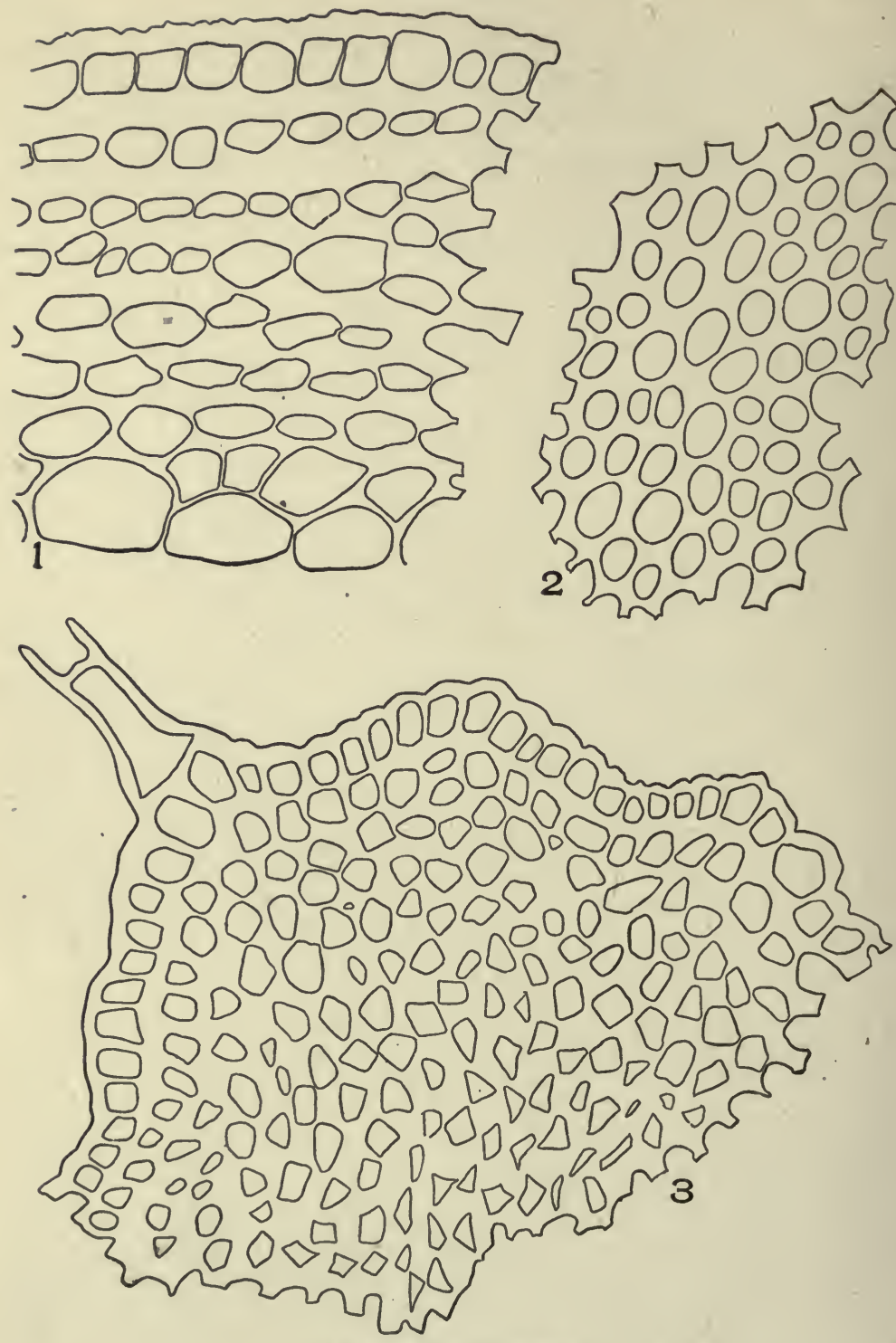

Collenchyma Cells

I. Cross-section of a side column of the collenchyma of motherwort stem (Leonurus cardiaca, L.).

2. Cross-section of the collenchyma of horehound stem (Marrubium vulgare, L.).

3. Cross-section of the collenchyma of the outer angle of motherwort stem. 
bark and the collenchyma of the stems of herbs, contain rhlorophyll.

The walls of collenchyma consist of cellulose.

\section{STONE CELLS}

Stone cells, like bast fibres, are branched or non-branched. Each group is then separated into subgroups according to wall structure (whether striated, or pitted and striated, etc.), thickness of wall and of cell cavity, color of wall and of cell contents, absence of color and of cell contents, etc.

\section{BRANCHED STONE CELLS}

Branched stone cells occur in a number of drugs. In witchhazel bark (Plate 3 I, Fig. 2) the walis are thick, white, and very porous. In some cells the branches are of equal length; in others they are unequal. In the tea-leaf (Plate 3 I, Fig. I) the walls are yellowish white and finely porous. When the lower wall is brought in focus, it shows numerous circular pits. These pits represent the pores viewed from the end. The branches frequently branch or fork.

Branched stone cells also occur in coto bark, acer spicatum, staranise, witch-hazel leaf, hemlock, and wild-cherry barks.

Non-branched stone cells are divided into two main groups, as follows:

I. Porous and striated stone cells, and,

2. Porous and non-striated store cells.

\section{POROUS AND STRIATED STONE CELLS}

Porous and striated walled stone cells occur in ruellia root, winter's bark, bitter root, allspice, and aconite. These stone cells are shown in Plate 33, Figs. I, 2, 3, 4, and 5.

The stone cells of ruellia root (Plate 32 , Fig. I) are greatly elongated, rectangular in form, with thick, white, strongly porous walls. The central cavity is narrow and is marked with prominent pores and striations.

The stone cells of winter's bark (Plate 32, Fig. 2) vary from elongated to nearly isodiametric. The pores are very large, 


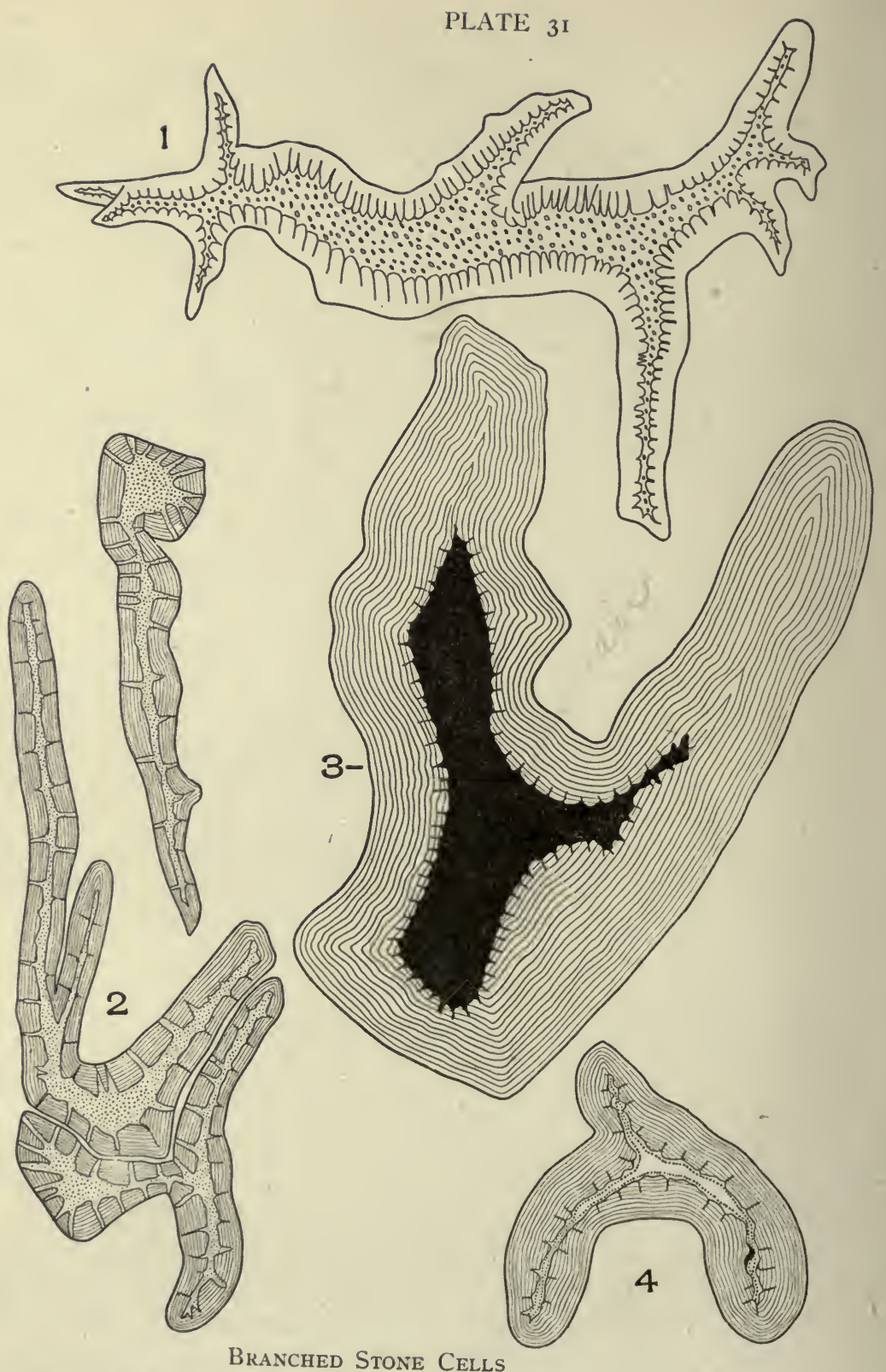

I. Tea leaf (Thea sinensis, L.).

2. Witch-hazel bark (Hamamelis virginiana, L.).

3. Hemlock bark (Tsuga canadensis, [L.] Carr).

4. Wild-cherry bark (Prunus serotina, Ehrh.). 
the light yellowish wall is irregularly thickened, and the central cavity is very large. The pores are prominent.

The stone cell of bitter root (Plate 32, Fig. 3) is nearly isodiametric. The walls are yellowish white and strongly porous and striated. The central cavity is about equal to the thickness of the walls.

The stone cell of allspice (Plate 32, Fig. 4) is mostly rounded in form, and when the outer wall only is in focus it shows numerous round and elongated pores. The central cavity is filled with masses of reddish-brown tannin. The striations are very prominent.

The diagnostic stone cell of aconite (Plate 32, Fig. 5) is rectangular or square in outline; the walls are yellowish and the central cavity has a diameter many times the thickness of the wall. The side and surface view of the pores is prominent, and the striations are very fine.

\section{POROUS AND NON-STRIATED STONE CELLS}

Porous and non-striated stone cells occur in Ceylon cinnamon, in calumba root, in dogwood bark, in cubeb, and in echinacea root.

The diagnostic stone cells of Ceylon cinnamon (Plate 33, Fig. I) are nearly square in outline; the walls are strongly porous and the large central cavity frequently contains starch.

The stone cells of calumba root (Plate 33, Fig. 2) vary in shape from rectangular to nearly square, and the walls are greenish yellow, unequally thickened, and strongly porous. The typical stone cells contain several prisms, usually four.

The stone cells of dogwood bark (Plate 33, Fig. 3) have thick, white walls with simple and branched pores. The central cavity frequently branches"and appears black when recently mounted, owing to the presence of air.

The stone cells of cubeb (Plate 33, Fig. 4) are very small, mostly rounded in outline, with a great number of very fine simple pores which extend from the outer wall to the central cavity. The wall is yellow and very thick.

The stone cells of echinacea root (Plate 33, Fig. 5) are very irregular in form; the walls are yellowish and porous, and the 
central cavity is very large. A black intercellular substance is usually adhering to portions of the outer wall.

The color of the walls of the different stone cells is very variable. In Ceylon cinnamon and ruellia the walls are colorless; in zanthoxylium, light yellow; in rumex, deep yellow; in cascara sagrada, greenish yellow.

The pores of stone cells, like the pores of bast fibres, are either simple or branched, and they may or may not extend through the entire wall. Many of the shorter pores extend for only a short distance from the cell cavity.

The width of the cell cavity varies considerably in the stone cells of the different plants. In aconite (Plate 32, Fig. 5), in calumba (Plate 33, Fig. 2), and in Ceylon cinnamon (Plate 33, Fig. I), the cell cavity is several times greater than the thickness of the cell wall.

In allspice (Plate 32, Fig. 4), in bitter root (Plate 32, Fig. 3 ), the diameter of the cell cavity and the thickness of the wall are about equal. In cubeb (Plate 33, Fig. 4), in ruellia (Plate 32, Fig. I), the wall is thicker than the diameter of the cell cavity.

The cavity of many stone cells contains no characteristic cell contents. In other stone cells the cell contents are as characteristic as the stone cell. The stone cells of both Saigon and Ceylon cinnamon (Plate 33, Fig. I) contain starch; the stone cells of calumba (Plate 33, Fig. 2) contain prisms of calcium oxalate; the stone cells of allspice and sweet-birch bark contain tannin.

In cross-sections, stone cells occur singly, as in Saigon cinnamon (Plate 34, Fig. I), ruellia (Plate 34, Fig. 2); in groups, as in cascara sagrada (Plate 34, Fig. 3); and in continuous bands, as in Saigon cinnamon (Plate 34, Fig. 4).

In pQwdered drugs, stone cells; like bast fibres, occur singly, as in ruellia, calumba, etc.; or in groups, as in cascara sagrada, witch-hazel bark, etc. In most powders they occur both singly and in groups.

The individual stone cells are mostly entire, as in ruellia, calumba, allspice, echinacea, etc. In cascara sagrada many of the stone cells are broken when the closely cemented groups are torn apart in the milling process. Many of the branched 


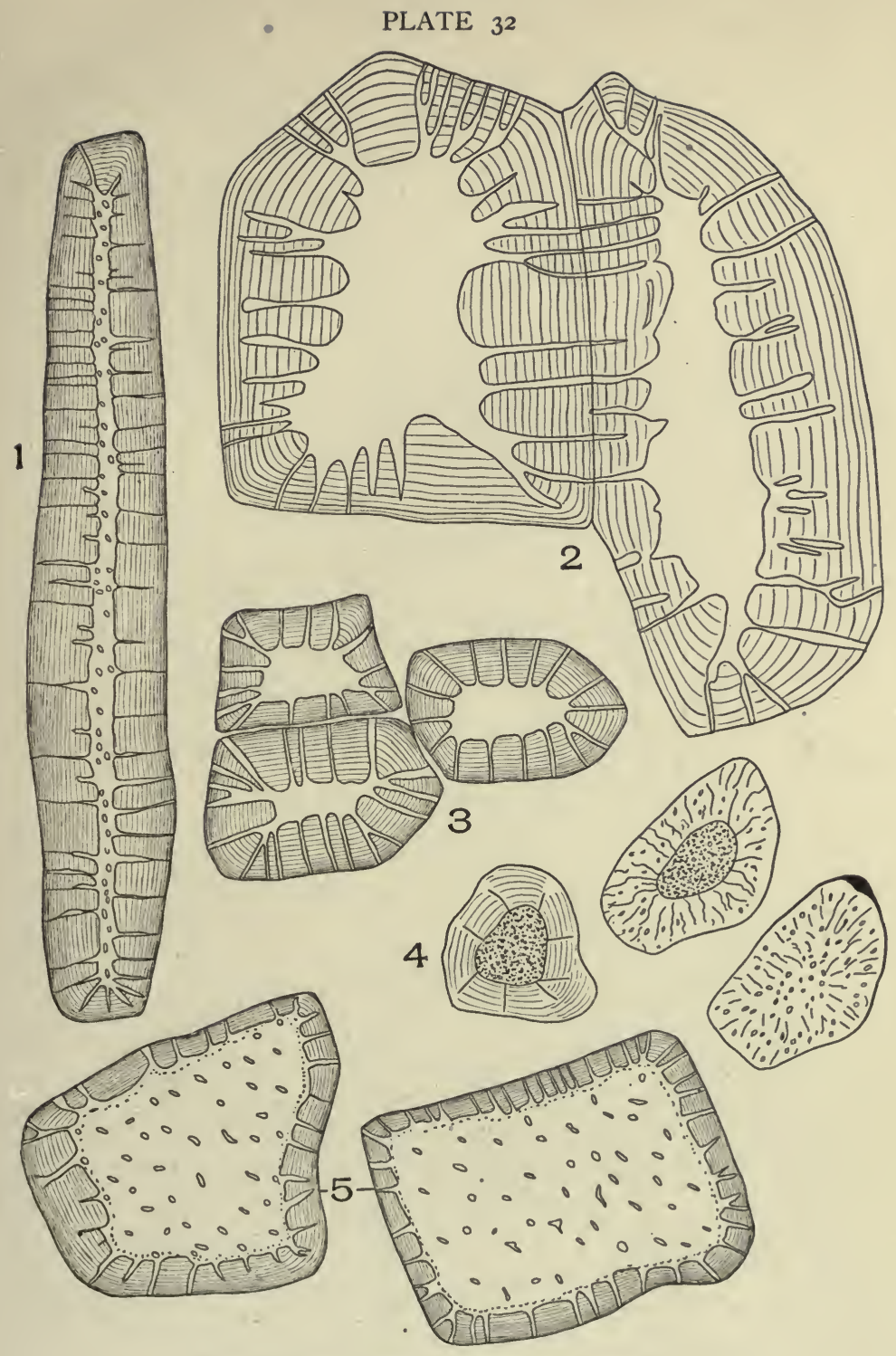

Porous and Striated Stone Cells

I. Ruellia root (Ruellia ciliosa, Pursh.).

2. Winter's-bark (Drimys winteri, Forst.).

3. Bitterroot (A pocynum androsamifolium, L.).

4. Allspice (Pimenta officinalis, Lind1.).

5. Aconite (Aconitum napellus, L.). 

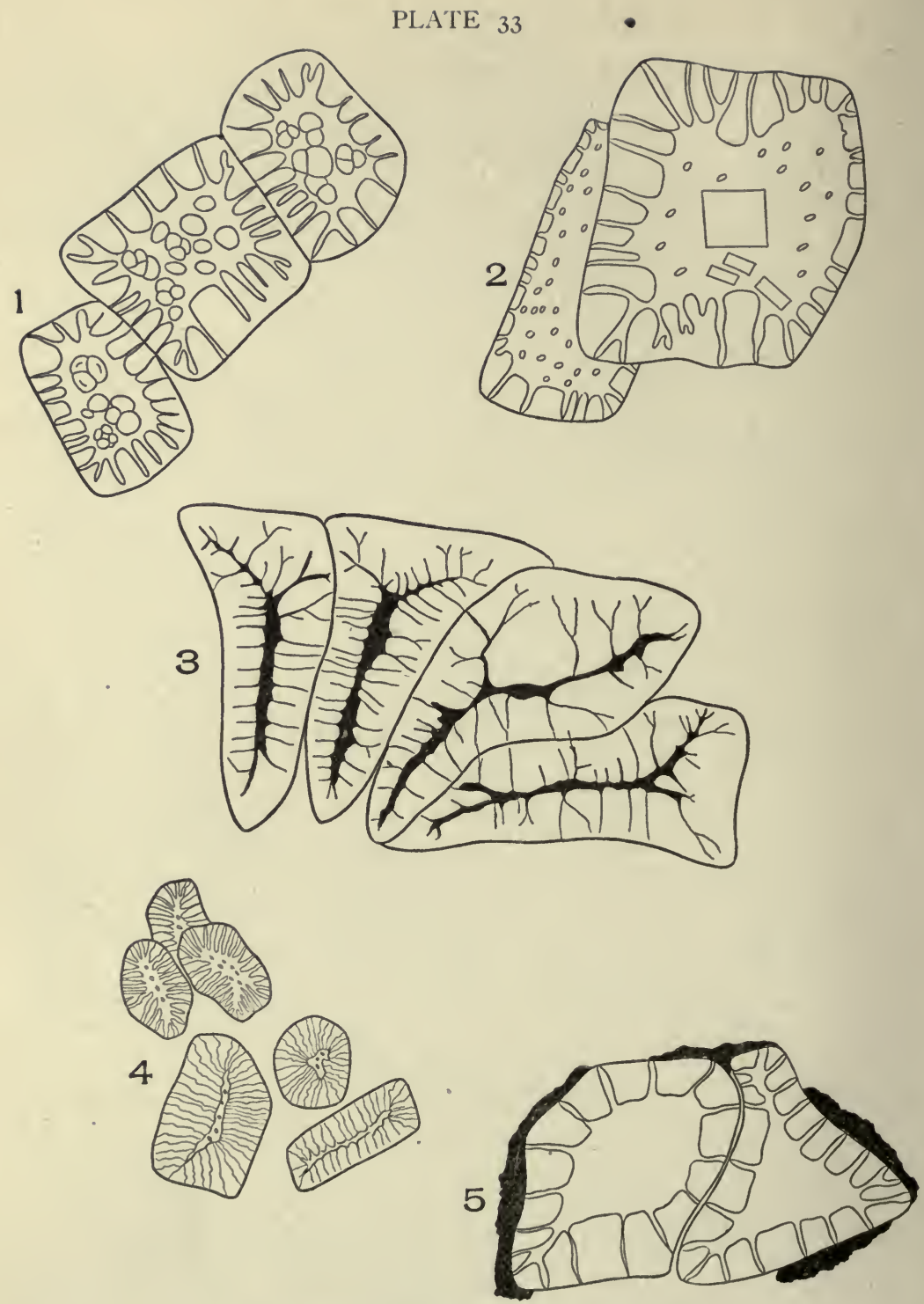

Porous and Non-Striated Stone Cells

I. Ceylon cinnamon (cinnamomum zeylanicum, Nees).

2. Calumba root (Jateorhiza palmata, [Lam.] Miers).

3. Dogwood root bark (Cornus florida, L.).

4. Cubeb (Piper cubeba, L., f.)

5. Echinacea (Echinacea angustifolia, D.C.) 


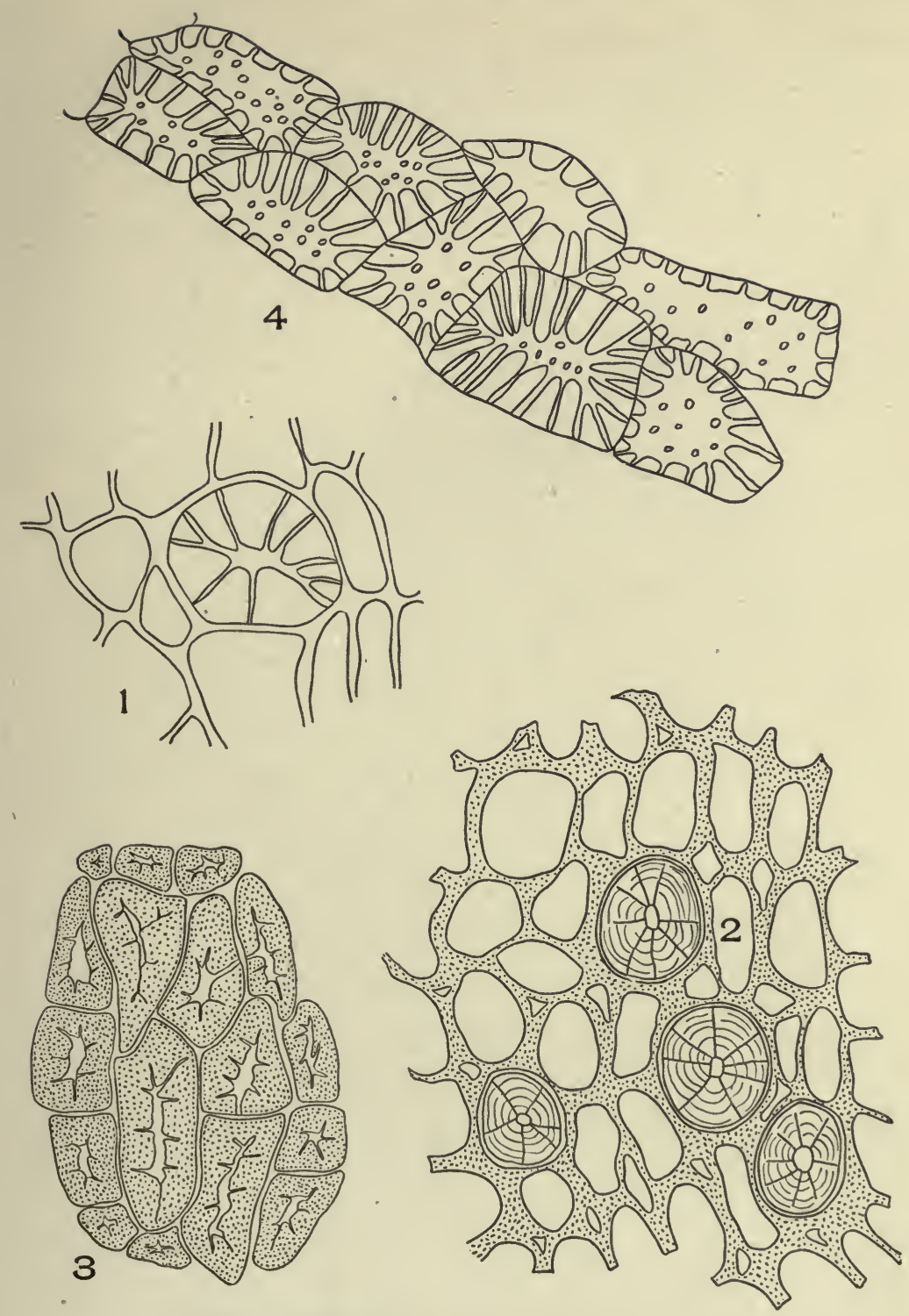

I. Saigon cinnamon.

2. Ruellia root (Ruellia ciliosa, Pursh.).

3. Cascara sagrada (Rhamnus purshiana, D.C.).

4. Saigon cinnamon. 
stone cells of witch-hazel bark and leaf, wild cherry, etc., also occur broken in the powder.

The walls of all stone cells are composed of lignin.

The form of stone cells varies greatly; in aconite the stone cells are quadrangular; in ruellia they are rectangular; in pimenta, circular or oval in outline; in most stone cells they are polygonal.

The lignified walls of stone cells are stained red with a solution of phloroglucin and hydrochloric acid, and the walls are stained yellow by aniline chloride.

\section{ENDODERMAL CELLS}

The endodermal cells of the different plants vary greatly in form, color, structure, and composition of the wall, yet these different endodermal cells may be divided into two groups: first, thin-walled parenchyma-like cells, and, secondly, thickwalled fibre-like cells. In the thin-walled endodermal cells the walls are composed of cellulose, and the cell terminations are blunt or rounded. When the drug is powdered the cells break up into small diagnostic fragments. In the thick-walled endodermal cells the walls are lignified and porous, and the ends of the cell are frequently pointed and resemble fibres.

Sarsaparilla root, triticum, convallaria, and aletris have thick-walled endodermal cells.

\section{STRUCTURE OF ENDODERMAL CELLS}

The endodermal cells of sarsaparilla root (Plate 35, Fig. I) are never more than one layer in thickness. The walls are porous and of a yellowish-brown color. Alternating with the thick-walled cell is a thin-walled cell, which is frequently referred to as a passage cell.

The endodermal cells of triticum (Plate 35, Fig. 2) are yellowish and the walls are porous and striated. There are one or two layers of cells. The cells forming the outer layer have very thin outer but thick inner walls, while the cells forming the inner layer are more uniform in thickness.

The endodermal cells of convallaria (Plate 35, Fig. 3) are yellowish white in color, and the walls are porous and striated. 

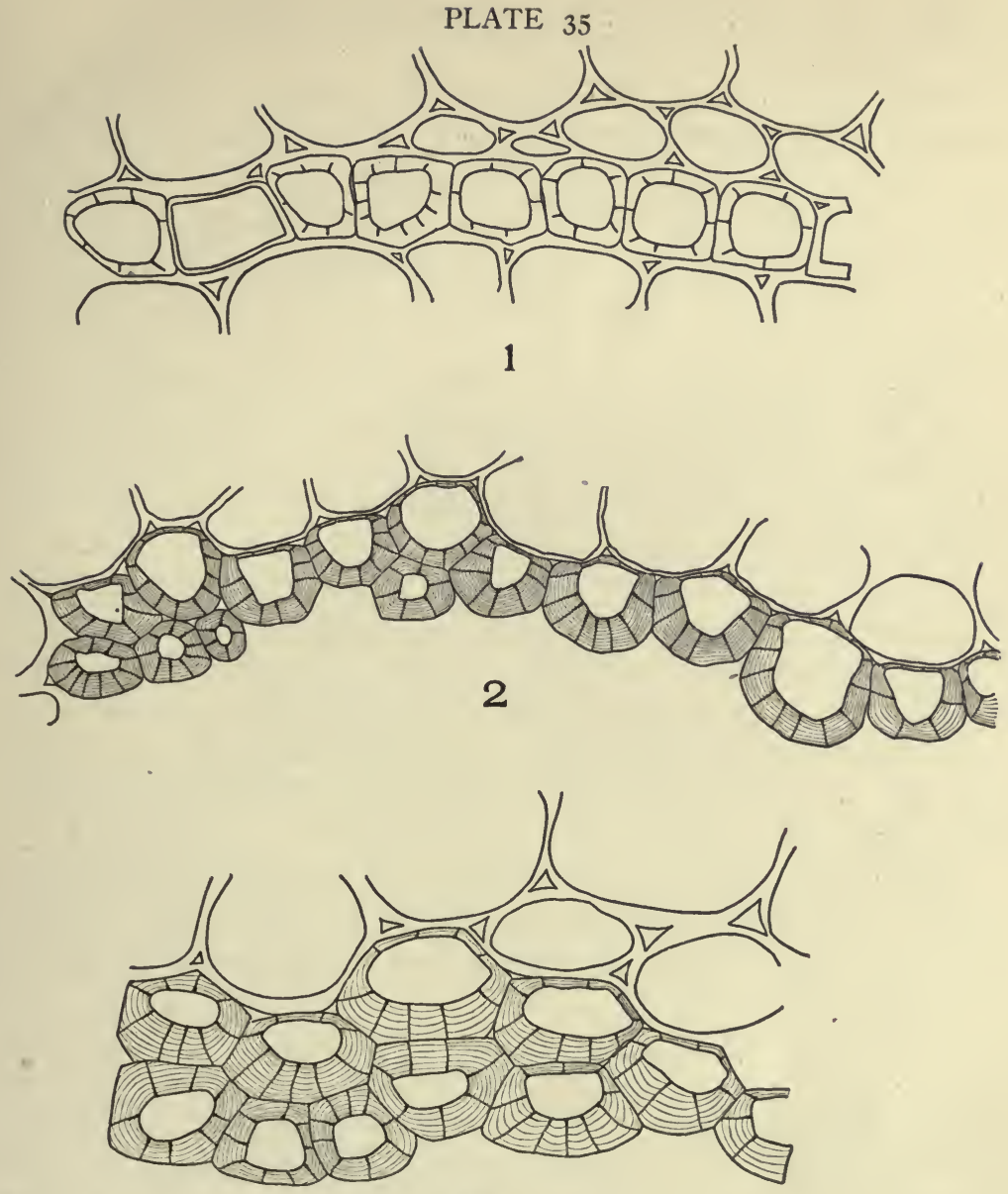

3

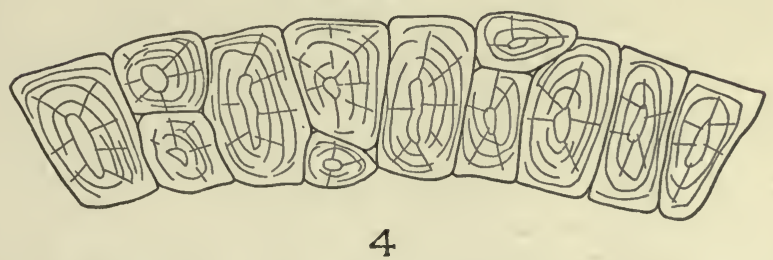

Cross-Sections of Endodermal Cells of

1. Sarsaparilla root (Smilax officinalis, Kunth).

2. Triticum (Agropyron repens, L.).

3. Convallaria (Convallaria majalis, L.)

4. Aletris (Aletris farinosa, L.). 
The outer wall of the layer of cells is thinner than the inner wall. The innermost layer of cell is more uniformly thickened.

The endodermal cells of aletris (Plate 35, Fig. 4) are yeliowish brown, slightly porous and striated. There are one or two layers of these cells, and two of the smaller cells usually occupy a space similar to that occupied by the radically elongated single cell.

On longitudinal view the endodermal cells of sarsaparilla triticum, convallaria, and aletris appear as follows:

Those of sarsaparilla (Plate 36 , Fig. I) are greatly e.ongated, the ends of the cells are blunt or slightly pointed, and the walls appear porous and striated.

Those of triticum (Plate 36, Fig. 2) are elongated, the walls are porous and striated, and the outer wall is much thinner than the inner wall. The end wall between two cells frequently appears common to the two cells.

Those of convallaria (Plate 36, Fig. 3) are elongated, and the end wall is usually blunt. The outer wall is thinner than the inner wall.

Those of aletris (Plate 36, Fig. 4) are fibre-like in appearance; the ends of the cells are pointed and the wall is strongly porous. The longitudinal view of these cells is shown in plate 36 .

\section{HYPODERMAL CELLS}

Hypodermal cells occur in sarsaparilla root and in triticum. In the cross-section of sarsaparilla root (Plate 37 , Fig. I) the hypodermal cells are yellowish or yellowish brown. The outer wall is thicker than the inner wall, the cell cavity is mostly rounded, and contains air. The walls are porous and finely striated. On longitudinal view the hypodermal cells of sarsaparilla (Plate 37, Fig. 2) are greatly elongated; the outer and side walls are thicker than the inner walls. The ends of the cells are blunt and distinct from each other.

In cross-section the hypodermal cells of triticum (Plate $37^{\circ}$, Fig. 3) are nearly rounded in outline, and the walls are of nearly uniform thickness. In longitudinal view (Plate 37, Fig. 4) the same cells appear parenchyma-like, and the walls between any two cells appear common to the two cells. 
PLATE 36

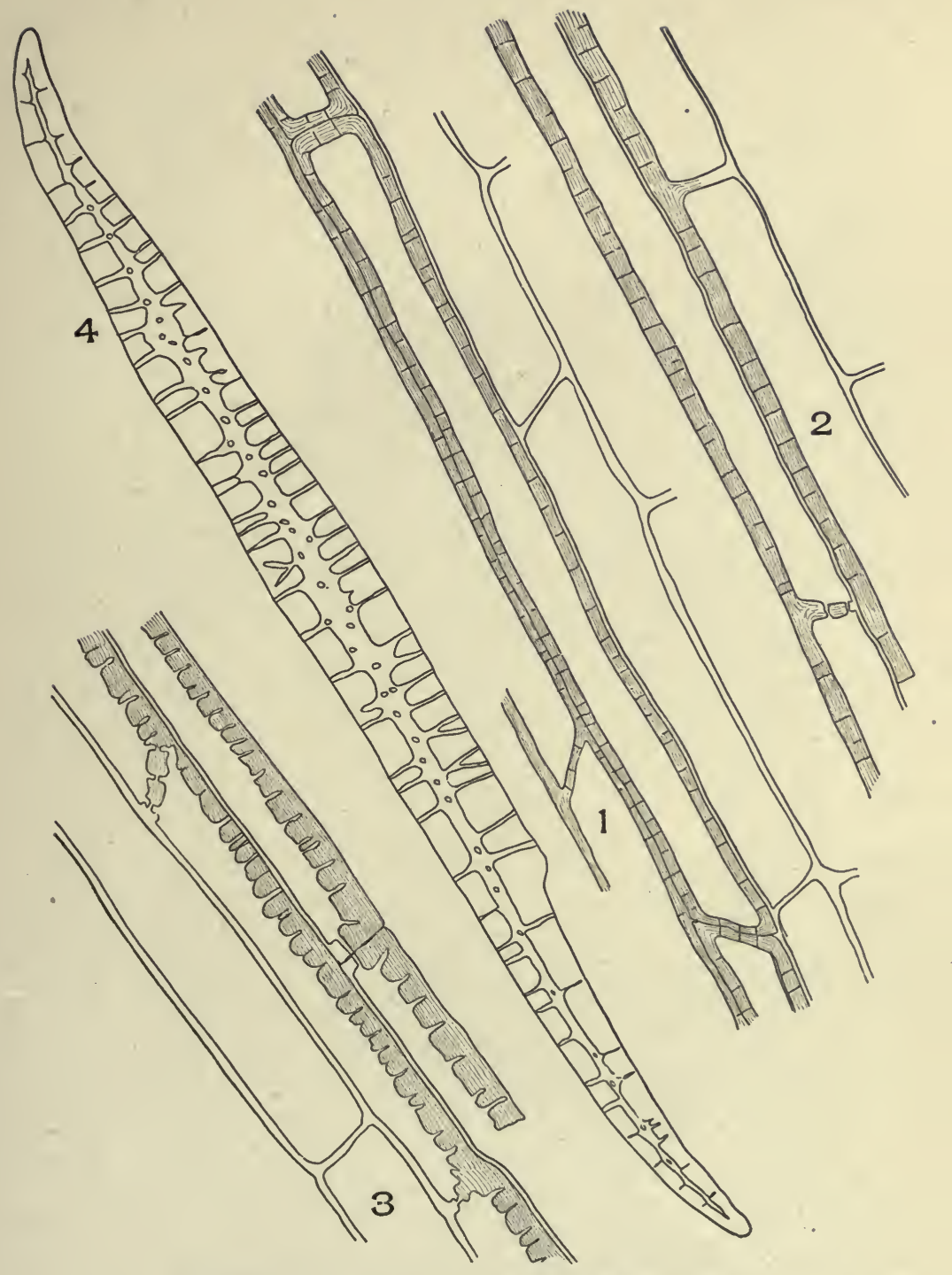

Longitudinal Sections of Endodermal Cells

I. Sarsaparilla root (Smilax officinalis, Kunth).

2. Triticum (Agropyron repens, L.).

3. Convallaria (Convallaria majalis, L.).

4. Aletris (Aletris farinosa, L.). 


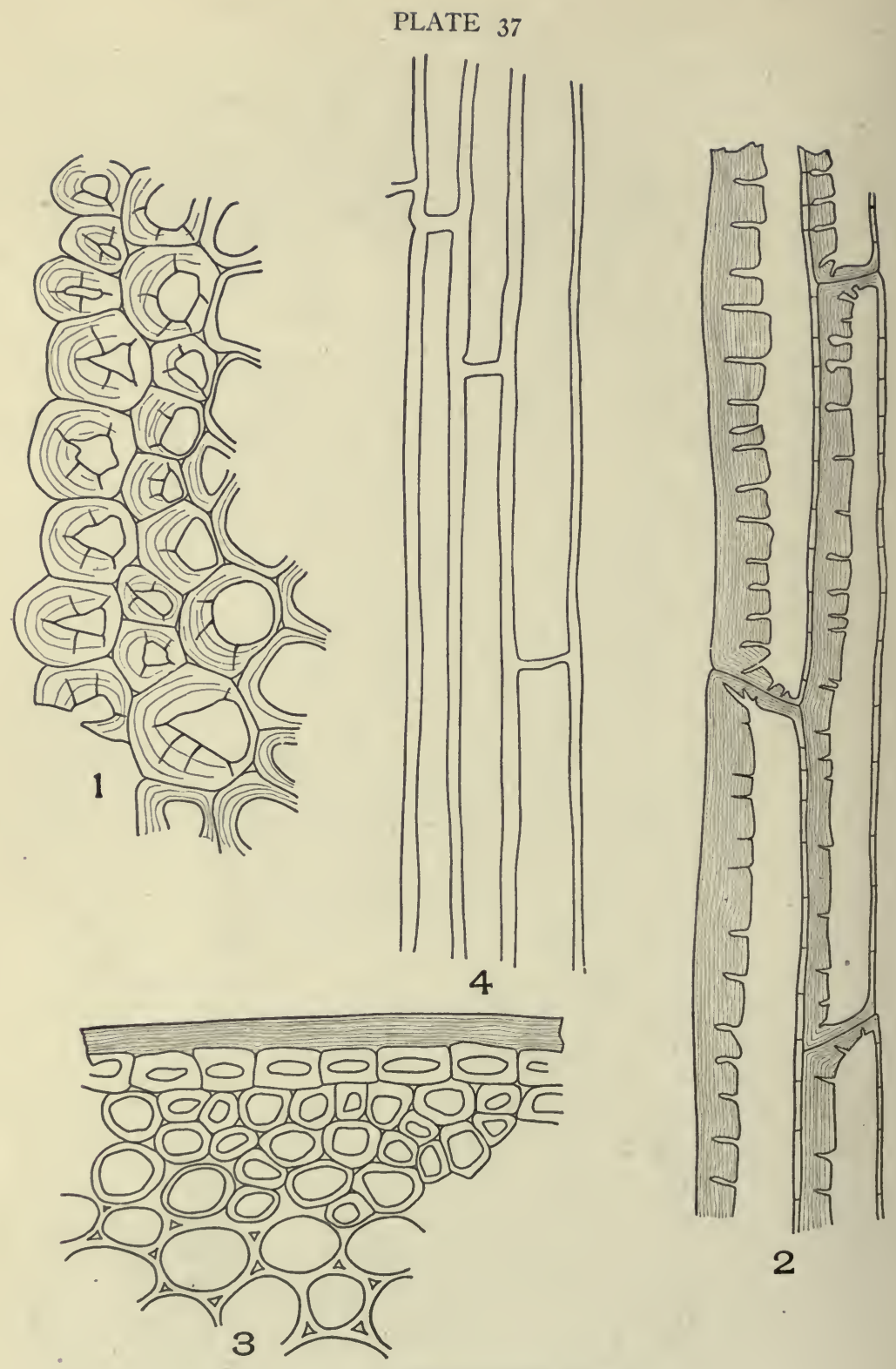

Hypodermal Cells

I. Cross-section sarsaparilla root (Smilcx officinalis, Kunth).

2. Longitudinal section sarsaparilla root (Smilax officinalis, Kunth).

3. Cross-section triticum (Agropyron repens, L.).

4. Longitudinal section triticum (Agropyron repens, L.). 


\section{CHAPTER IV}

\section{ABSORPTION TISSUE}

Most plants obtain the greater part of their food, first, from the soil in the form of a watery solution, and, secondly, from the air in the form of a diffusible gas. In a few cases all the food material is obtained from the air, as in the case of epiphytic plants. In such plants the aerial roots have a modified outer layer-velamen-which functions as a water-absorbing and gascondensing tissue. Many xerophytic. plants absorb water through the trichomes of the leaf. Such absorption tissue enables the plant to absorb any moisture that may condense upon the leaf and that would not otherwise be available to the plant. The water-absorbing tissue of roots is restricted to the root hairs, which are found, with few exceptions, only on young developing roots.

\section{ROOT HAIRS}

Root hairs usually occur a short distance back of the root cap. There is, in fact, a definite zone of the epidermis on which the root hairs develop. This zone is progressive. As the root elongates the root hairs continue to develop, the zone of hairs always remaining at about the same distance from the root cap. With the development of new zones of growth the hairs on the older zone die off and finally become replaced by an epidermis, or a periderm, except in the case of sarsaparilla root, and possibly other roots that have persistent root hairs.

Each root hair is an outgrowth from an epidermal cell (Plate 38, Fig. 3). The length of the hair and its form depend upon the nature of the soil, whether loose or compact, and upon the amount of water present.

A root hair is formed by the extension of the peripheral wall of an epidermal cell. At first this wall is only slightly papillate, but gradually the end wall is extended farther and farther from 
the surface of the root, caused by the development of side walls by the growing tip of the root hair until a tube-like structure, root hair, is produced. The root hair is then a modified epidermal cell. The protoplast lines the cell, and the central part of the root hair consists of a large vacuole filled with cell sap. The wall of the root hair is composed of cellulose, and the outermost part is frequently mucilaginous. As the root hairs develop, they become bent, twisted, and of unequal diameter, as a result of growing through narrow, winding soil passages. During their growth, the root hairs become firmly attached to the soil particles. The walls of root hairs give an acid reaction caused by the solution of the carbon dioxide excreted by the root hair. The acid character of the wall attracts moisture, and in addition has a solvent action on the insoluble compounds contained in the soil. It will thus be seen that the method of growth, structure, composition, and reaction of the wall of the root hair is perfectly suited to carry on the work of absorbing the enormous quantities of water needed by the growing plant. It is a well-known fact that when two solutions of unequal density are separated by a permeable membrane, the less dense liquid will pass through the membrane to the denser liquid. The wall of the root hair acts like an osmatic membrane. The less dense watery solution outside the root hair passes through its wall and into the denser cell sap solution. As the solution is absorbed, it passes from the root hair into the adjoining cortical parenchyma cells.

It is a fact that root hairs are seldom found in abundance on medicinal roots. This is due to the fact that root hairs occur only on the smaller branches of the root, and that when the root is pulled from the ground the smaller roots with their root hairs are broken off and left in the soil. For this reason a knowledge of the structure of root hairs is of minor importance in the study of powdered drugs. An occasional root hair is found, however, in most powdered roots, but root hairs have little or no diagnostic value, except in false unicorn root and sarsaparilla. When false unicorn root is collected, most of the root hairs remain attached to the numerous small fibrous roots, owing to the fact that these roots are easily removed from the sandy soil in which the plants grow. The root hairs of false 


\section{PLATE 38}

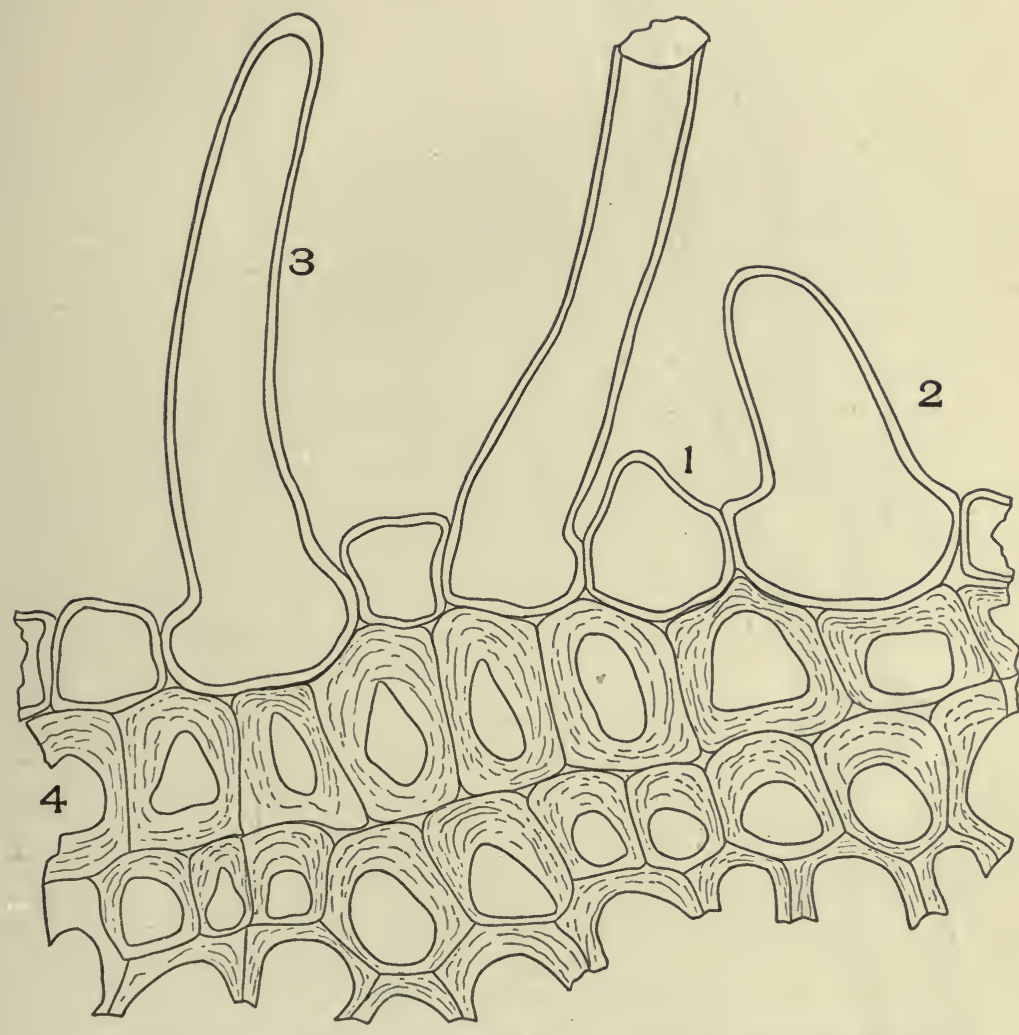

Cross-Section of Sarsaparilla Root (Smilax officinalis, Kunth)

I. Epidermal cell developing into a root hair.

2. Developing root hair.

3. Nearly mature root hair.

4. Hypodermal cells. 
PLATE 39

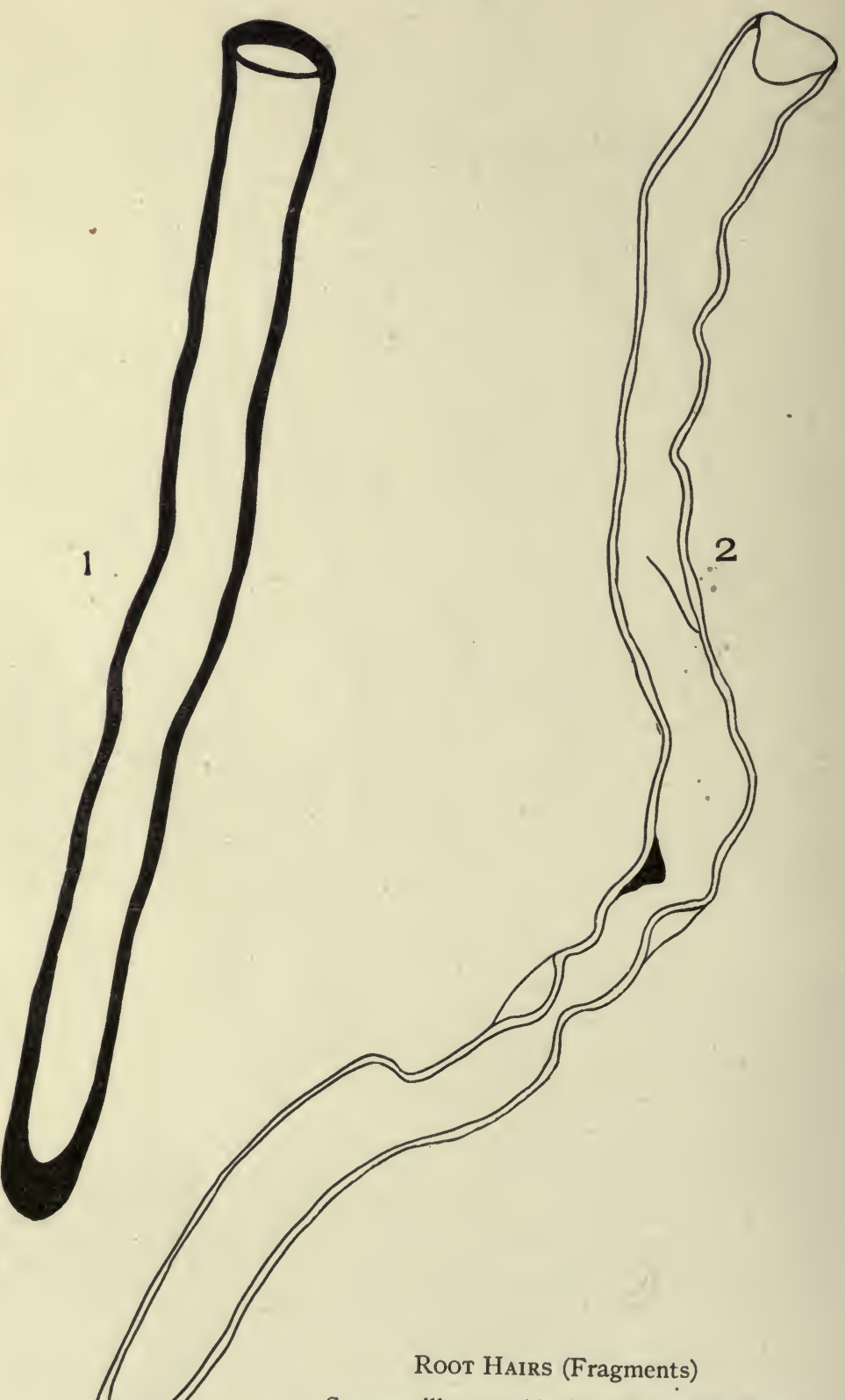

I. Sarsaparilla root (Smilax officinalis, Kunth).

2. False unicorn root (Helonias bullate, L.). 
unicorn are so abundant and so large that they form dense mats, which are readily seen without magnification. These hairs are, therefore, macroscopically as well as microscopically diagnostic. The root hairs of false unicorn (Plate 39, Fig. 2) have white, wavy, often decidedly indented walls. The terminal, or end wall, is rounded and much thicker than the side walls.

In sarsaparilla (Plate 39, Fig. I) the root hairs are curved and twisted. The end wall is thicker than the side walls. In some hairs the walls are as thick as the walls of the thin-walled bast fibres. This accounts for the fact that the root hairs are persistent on even the older portions of sarsaparilla root, and it serves also to explain why these root hairs remain on the root even after being pulled from the firmly packed earth in which the root grows.

\section{WATER ABSORPTION BY LEAVES .}

In many xerophytic terrestrial plants, the trichomes occurring on leaves act as a water-absorbing tissue. In such plants the walls of the hairs are composed largely of cellulose. It is obvious that these hairs absorb the water of condensation caused by dew and light rains-water which could not reach the plant except by such means.

There is no special tissue set aside for the absorption of gases from the air. Carbon dioxide, which contributes the element carbon to the starch formed by photosynthesis, enters the leaf by way of the stoma and lenticels. The structure and the chief functions of these will be considered under aërating tissue. 


\section{CHAPTER V}

\section{CONDUCTING TISSUE}

All cells of which the primary or secondary function is that of conduction are included under conducting tissue. It will be understood how important the conducting tissue is when the enormous quantity of water absorbed by a plant during a growing season is considered. It will then be realized that the conducting system must be highly developed in order to transport this water from one organ to another, and, in fact, to all the cells of the plant. Special attention must be given to the occurrence, the structure, the direction of conduction, and to the nature of the conducted material.

The cells or , cell groups comprising the conducting tissue are vessels and tracheids, sieve tubes, medullary ray cells, latex tubes, and parenchyma.

\section{VESSELS}

Vessels and tracheids form the principal upward conducting tissue of plants. They receive the soil water expressed from the cortical parenchyma cells located in the region of the root, immediately back of the root hair zone. This soil water, with dissolved crude inorganic and organic food materials, after entering the vessels and tracheids passes up the stem. The cells needing water at the different heights absorb it from the vessels, the excess finally reaching the leaves. When the stem branches, the water passes into the vessels of the branches and finally to the leaves of the branch. In certain special cases the vessels conduct upward soluble food material. In spring sugary sap flows upward through the vessels of the sugar maple.

Vessels are tubes, often of great length, formed from a number of superimposed cells, in which the end walls have become absorbed. The vessels therefore offer little resistance to the transference of water from the roots to the leaves of a plant. 
The combined length of the vessels is about equal to the height of the plant in which they occur. The length of the individual vessels varies from a fraction of a meter up to several meters.

\section{ANNULAR VESSELS}

The annular vessels are thickened at intervals in the form of rings (Plate 40, Fig. I), which extend outward from and around the inner wall of the vessel. In fact, it is the inner wall which is thickened in all the different types of vessels. The ring-like thickening usually separates from the wall when the drug is powdered. Such separated rings occur frequently in powdered digitalis, belladonna, and stramonium leaves. Annular vessels are not, however, of diagnostic importance, because more characteristic cells are found in the plants in which they occur. Not infrequently a vessel will have annular thickenings at one end and spiral thickenings at the other. Such vessels are found in the pumpkin stem (Plate 40, Fig. I).

Vessels are distinguished from other cells by their arrangement, by their large size when seen in cross-section, and by the thickening of the wall when seen in longitudinal sections of the plant or in powders. The side walls of vessels are thickened in a number of striking yet uniform ways. The chief types of thickening of the wall, beginning with one that is the least thickened, are annular, spiral, sclariform, pitted, and pitted with bordered pores.

\section{SPIRAL VESSELS}

In the spiral vessel the thickening occurs in the form of a spiral, which is readily separated from the side walls. This is particularly the case in powdered drugs, where the spiral thickening so frequently separates from the cell wall. There are three types of spiral vessels: those with one (Plate 4I, Fig. I), those with two, and those with three spirals. Single spirals occur in most leaves; double spirals occur in many plants (Plate 4I, Fig. 2), but they are particularly striking in powdered squills. Triple spirals are characteristic of the eucalyptus leaf (Plate 4I, Fig. 3); in fact, they form a diagnostic feature of the powder. Frequently a spirally thickened wall indicates a developmental stage of the vessel. Many such vessels are 
spirally thickened at first, but later, when mature, an increased amount of thickening occurs and the vessel becomes a reticulate or pitted vessel. Many mature vessels, however, are spirally thickened as indicated above. In herbaceous stems and in certain roots and leaves spiral vessels are associated with the sclariform reticulate and pitted type. In certain cases a single spiral band will branch as the vessel matures.

There is a great variation in the amount of spiral thickening occurring in a vessel. In leaves, particularly, the spiral appears loosely coiled; while in squills and other rhizomes and roots the spiral appears as a series of rings. When viewed by high power only half of each spiral band is visible. At either side of the cell the exact size and form of the thickening appear in two parallel rows of dark circles or projections from the walls. This thickening of the wall is rendered visible from the fact that the light is retarded as it passes through that portion of the spiral extending from the upper to the under side of the spiral; while the light readily traverses the upper and lower cross bands of the vessel.

It should be remembered that, when the upper part of the spiral vessel is in focus, the bands appear to bend in a direction away from the eye; while when the under side of the bands are in focus, the bands appear to bend toward the eye. These facts will show that it is necessary to focus on both the upper and lower walls in studying spiral vessels. In double spiral vessels the spirals are frequently coiled in opposite directions; therefore the bands appear to cross one another. In eucalyptus leaf the three bands are coiled in the same direction. In all cases the thickening occurs on all sides of the wall. Its appearance will, therefore, be the same no matter at what angle the vessel is viewed.

\section{SCLARIFORM VESSELS}

Sclariform vessels have interrupted bands of thickening on the inner walls. Two or more such bands occur between the two side walls. The series of bands are separated by uniformly thickened portions of the wall extending parallel to the length of the vessel. Sclariform vessels are usually quite broad, so that it is necessary to change the focus several times in order 

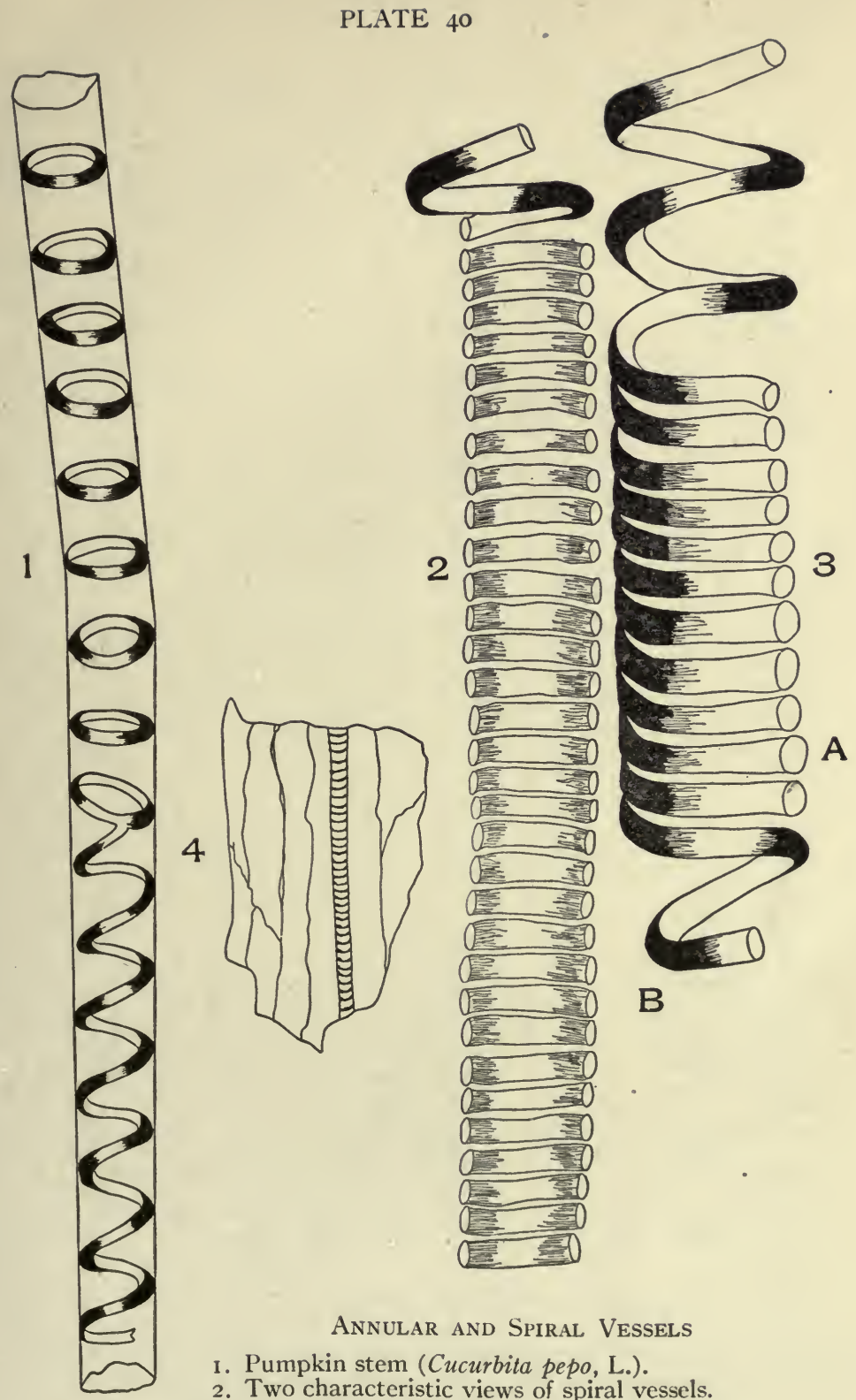

\section{Annular and Spiral Vessels}

I. Pumpkin stem (Cucurbita pepo, L.).

2. Two characteristic views of spiral vessels.

3. (A) Upper part of spiral vessel in focus.

$(B)$ Under part of spiral vessel in focus.

4. Spiral vessel of the disk petal matricaria (Matricaria chamomilla, L.). 

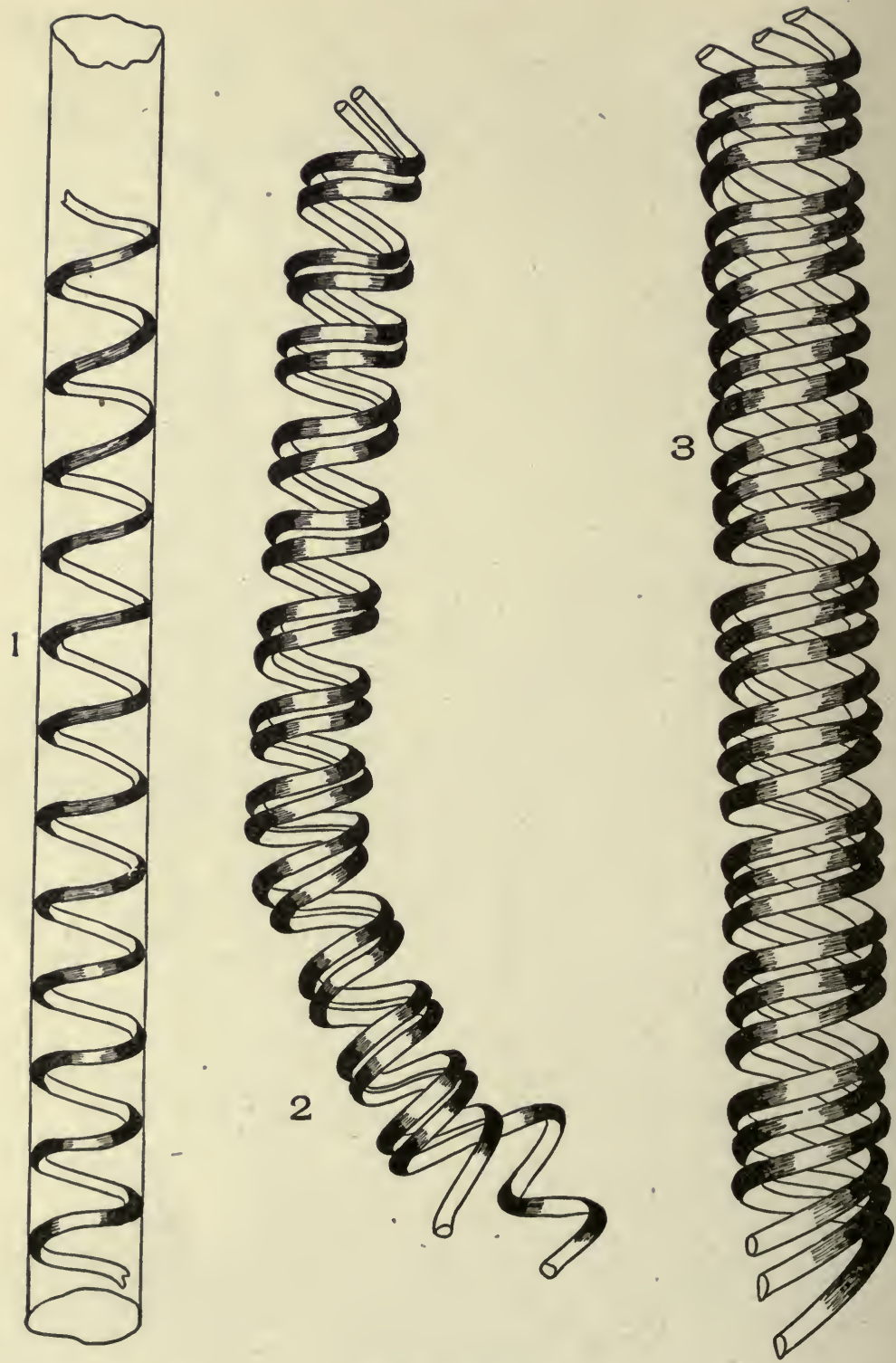

SPIRAL Vessels

I. Single spiral vessel of pumpkin stem (Cucurbita pepo, L.).

2. Double spiral vessel of squill bulb (Urginea maritima, [L.] Baker).

3. Triple spiral vessel of eucalyptus leaf (Eucalyptus globulus, Labili). 
to bring the different series of bands in focus. The series of bands are usually of unequal width and length.

Sclariform vessels occur in male fern (Plate 42, Fig. 2), calamus, tonga root (Plate 42, Fig. 3), and sarsaparilla (Plate 42 , Fig. I). In each they are characteristic. Sclariform vessels, with these few exceptions, do not occur in drug plants. In fact, drugs derived from dicotyledones rarely have sclariform vessels. They occur chiefly in the ferns and drugs derived from monocotyledenous plants. Their presence or absence should, therefore, be noted when studying powdered drugs.

\section{. RETiculate VESSELS}

Reticulate vessels are of common occurrence in medicinal plants. In fact, they occur more frequently than any other type of vessel. The basic structure of reticulate vessels (Plate 43 , Fig. I) occurring in different plants is similar, but they vary in a recognizable way in different plants (Plate 43, Fig. 2). The walls of reticulate vessels are thickened to a greater extent than are the walls of spirally thickened vessels.

\section{PITTED VESSELS}

Pitted vessels are met with most frequently in woods and wood-stemmed herbs. There are two distinct types of pitted vessels-i.e., simple pitted vessels and pitted vessels with bordered pores.

The pitted vessel represents the highest type of cell-wall thickening. The entire wall of the vessel is thickened, with the exception of the places where the pits occur. The number and size of the pits vary greatly in different drugs. In quassia (Plate 44, Fig. I) the pits are numerous and very small, and the openings are nearly circular in outline. In white sandalwood (Plate 44, Fig. 3), the pits are few in number, but when they do occur they are much larger than are the pits of quassia.

\section{PITTED VESSELS WITH BORDERED PORES}

Pitted vessels with bordered pores are of common occurrence in the woody stems and stems of many herbaceous plants (Plate 45, Figs. 3 and 4). In such vessels the wall is unthickened for a short distance around the pits. This unthickened portion 

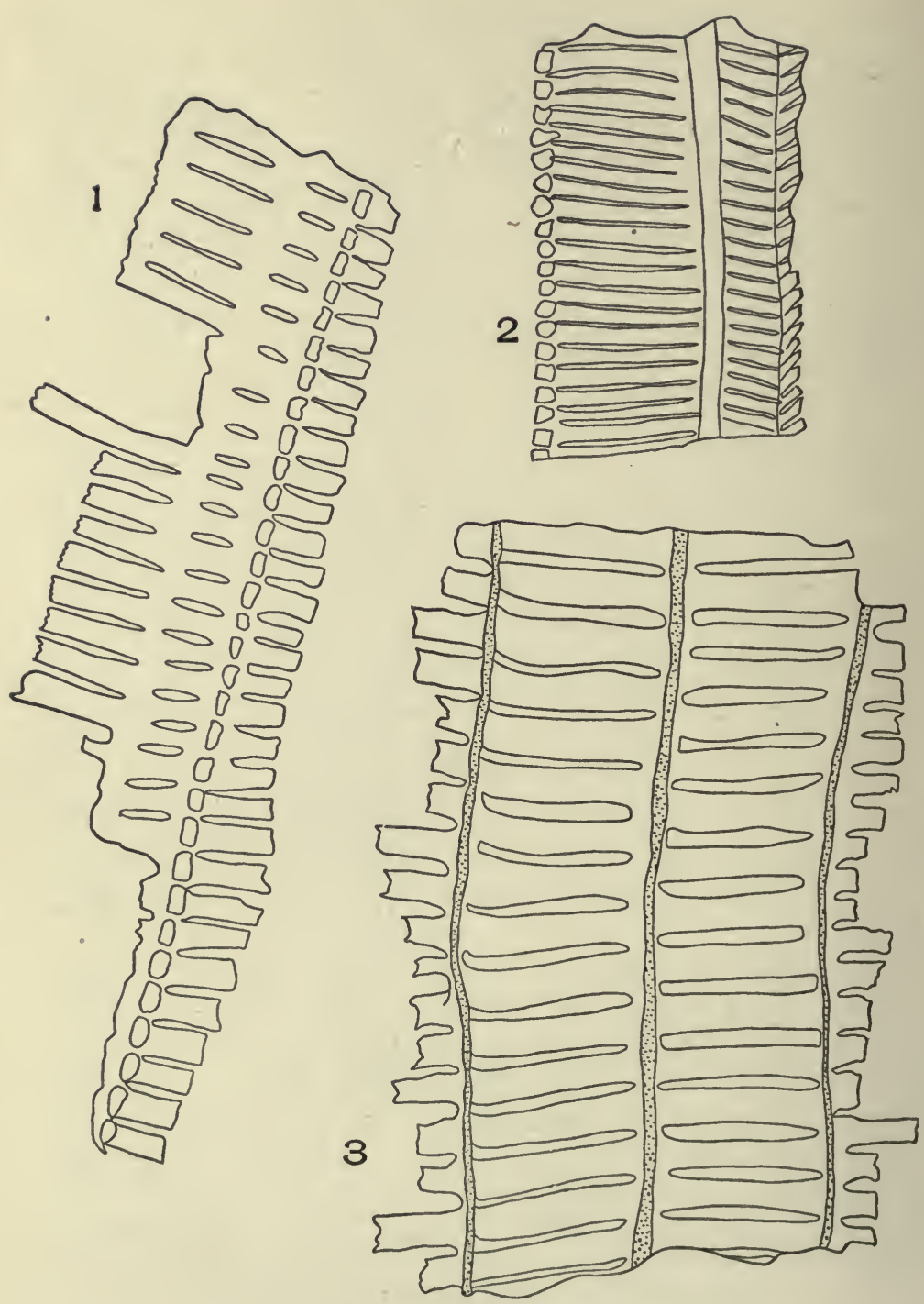

SClariform VESSELS

I. Sarsaparilla root (Smilax officinalis, Kunth).

2. Male fern (Dryopteris marginalis, [L.] A. Gray).

3. Tonga root. 

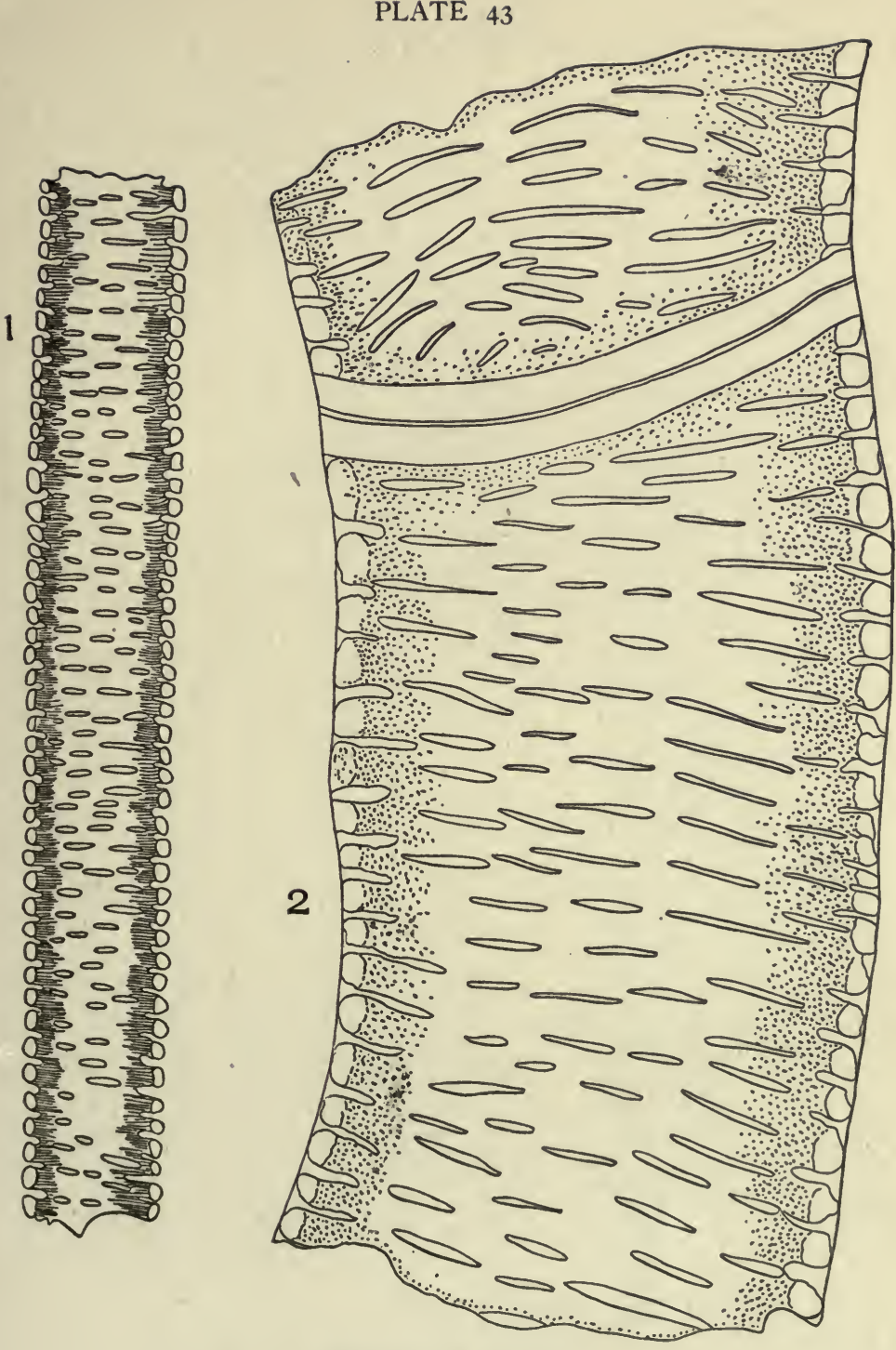

Reticulate Vessels

I. Hydrastis rhizome (Hydrastis canadensis, L.).

2. Musk root (Ferula sumbul, [Kauffm.] Hook., f.). 

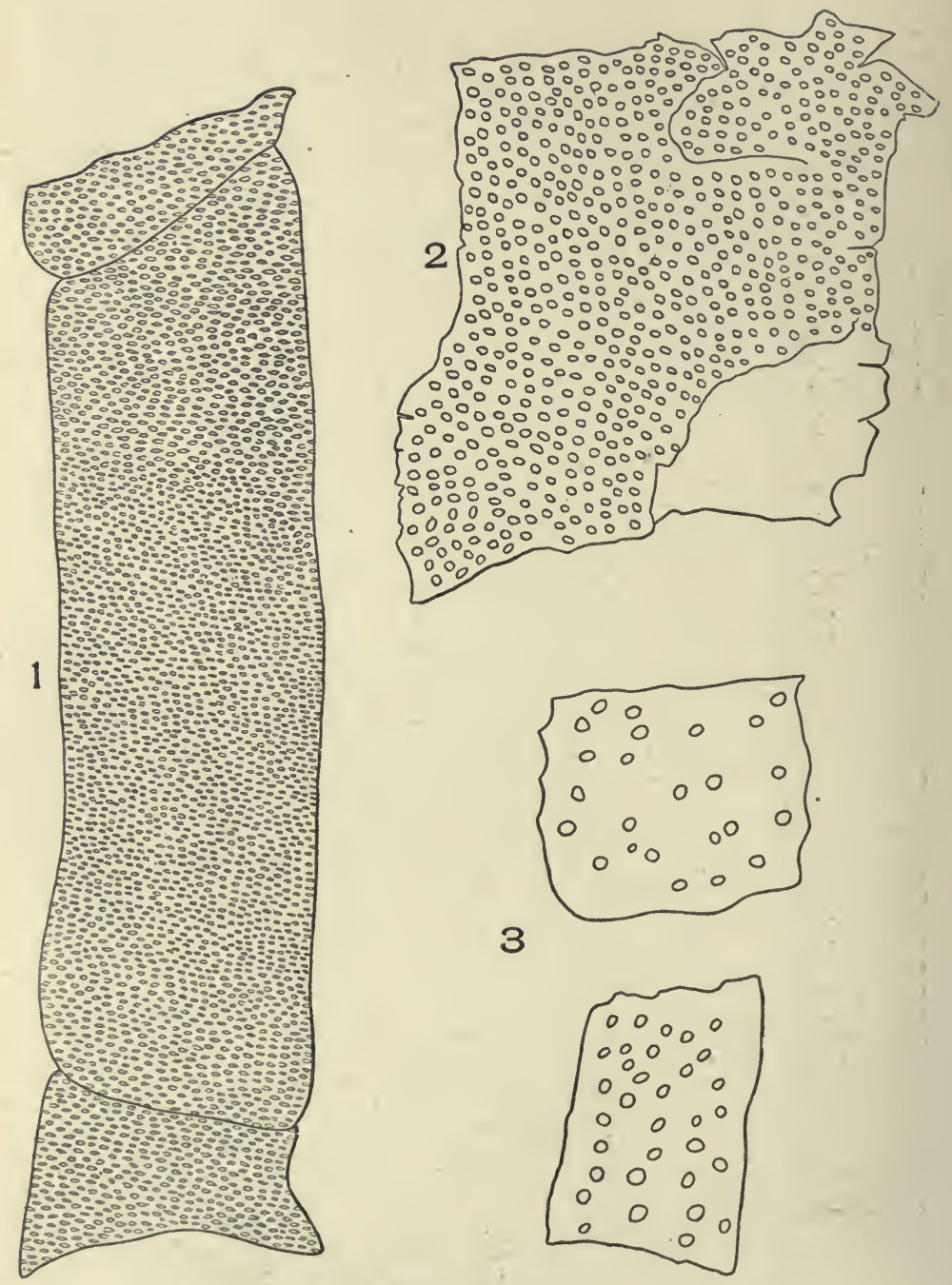

Pitted Vessels

I. Quassia, low magnification (Picrana excelsa, [Swartz] Lind1.).

2. Quassia, high magnification.

3. White sandalwood (Santalum album, L.). 

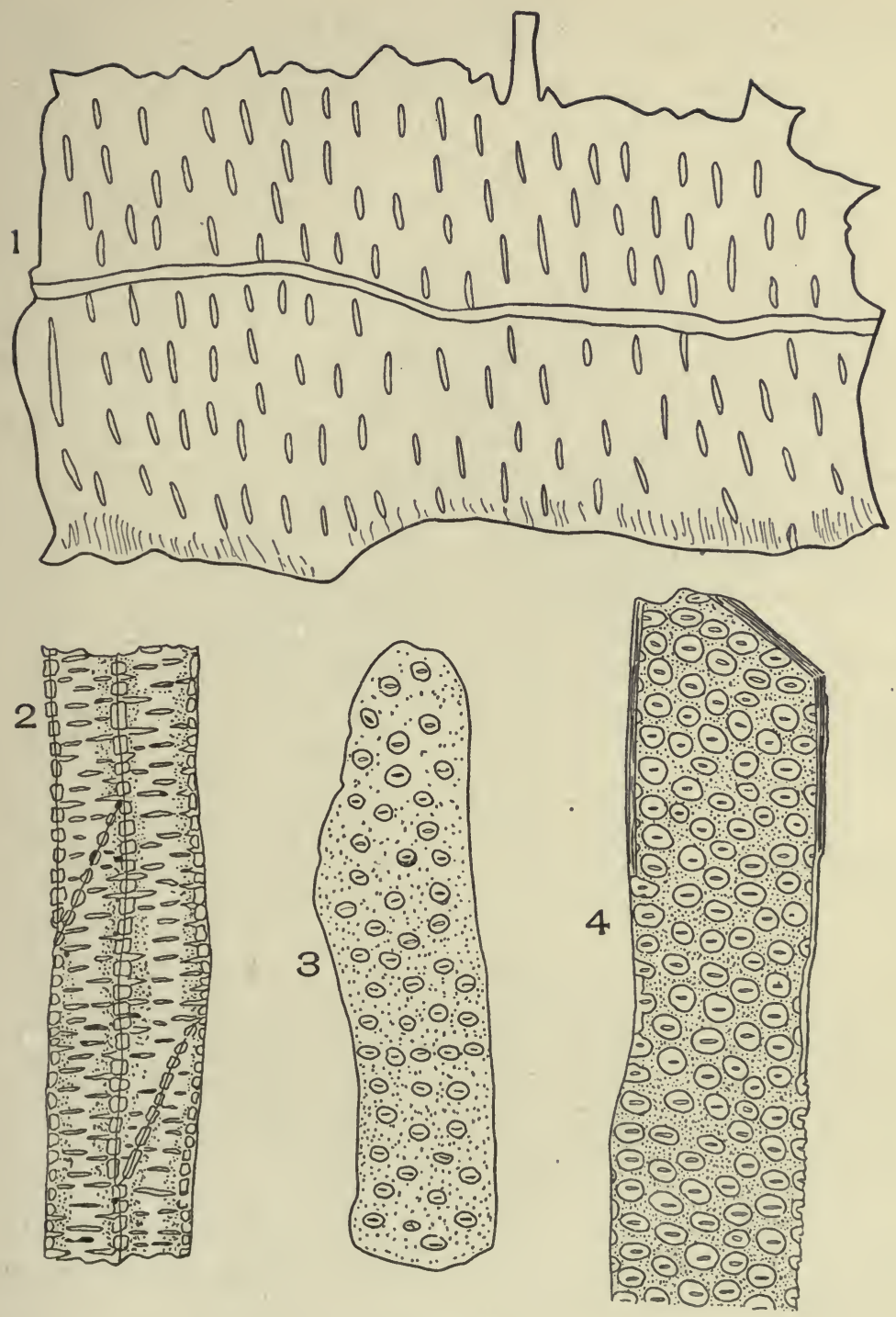

\section{VESSELS}

I. Reticulate vessel of calumba root (Jateorhiza palmata, [Lam.] Miers).

2. Reticulate tracheid of hydrastis rhizome (Hydrastis canadensis, L.).

3. Pitted vessel with bordered pores of belladonna stem.

4. Pitted vessel with bordered pores of aconite stem (A conitum napellus,L.). 
may be either circular or angled in outline, a given form being constant to the plant in which it occurs. The pits vary from oval to circular. Pitted vessels with bordered pores occur in belladonna and aconite stems.

Vessels and tracheids lose their living-cell contents when fully developed. In the vessels the cell contents disappear at the period of dissolution of the cell wall.

The walls of vessels and tracheids are composed of lignin, a substance which prevents the collapsing of the walls when the surrounding cells press upon them, and which also prevents the tearing apart of the wall when the vessel is filled with ascending liquids under great pressure. Lignin thus enables the vessel to resist successively compression and tearing forces.

Tracheids are formed from superimposed cells with oblique perforated end walls. The side walls of tracheids are thickened in a manner similar to those of vessels. The tracheids in golden seal are of a bright-yellow color, and groups of these short tracheids scattered throughout the field form the most characteristic part of the powdered drug. In ipecac root the tracheids are of a porcelain-white, translucent appearance, and they are much longer than are the tracheids of golden seal.

The cellulose walls of parenchyma cells are stained blue with hæmatoxylin and by chlorzinciodide. Cellulose is completely soluble in a fresh copper ammonia solution.

\section{SIEVE TUBES}

Sieve tubes are downward-conducting cells. They conduct downward proteid food material. This fact is easily demonstrated by adding iodine to a section containing sieve tubes, in which case the sieve tubes are turned yellow.

Developing sieve tubes have all the parts common to a living cell; but when fully mature, however, the nucleus becomes disorganized, but a layer of protoplasm continues to line the cell wall.

Sieve tubes (Plate 46, Fig. I) are composed of a great number of superimposed cells with perforated end walls and with nonporous cellulose side walls. The end walls of two adjoining cells are greatly thickened and the pores pass through both 
PLATE 46

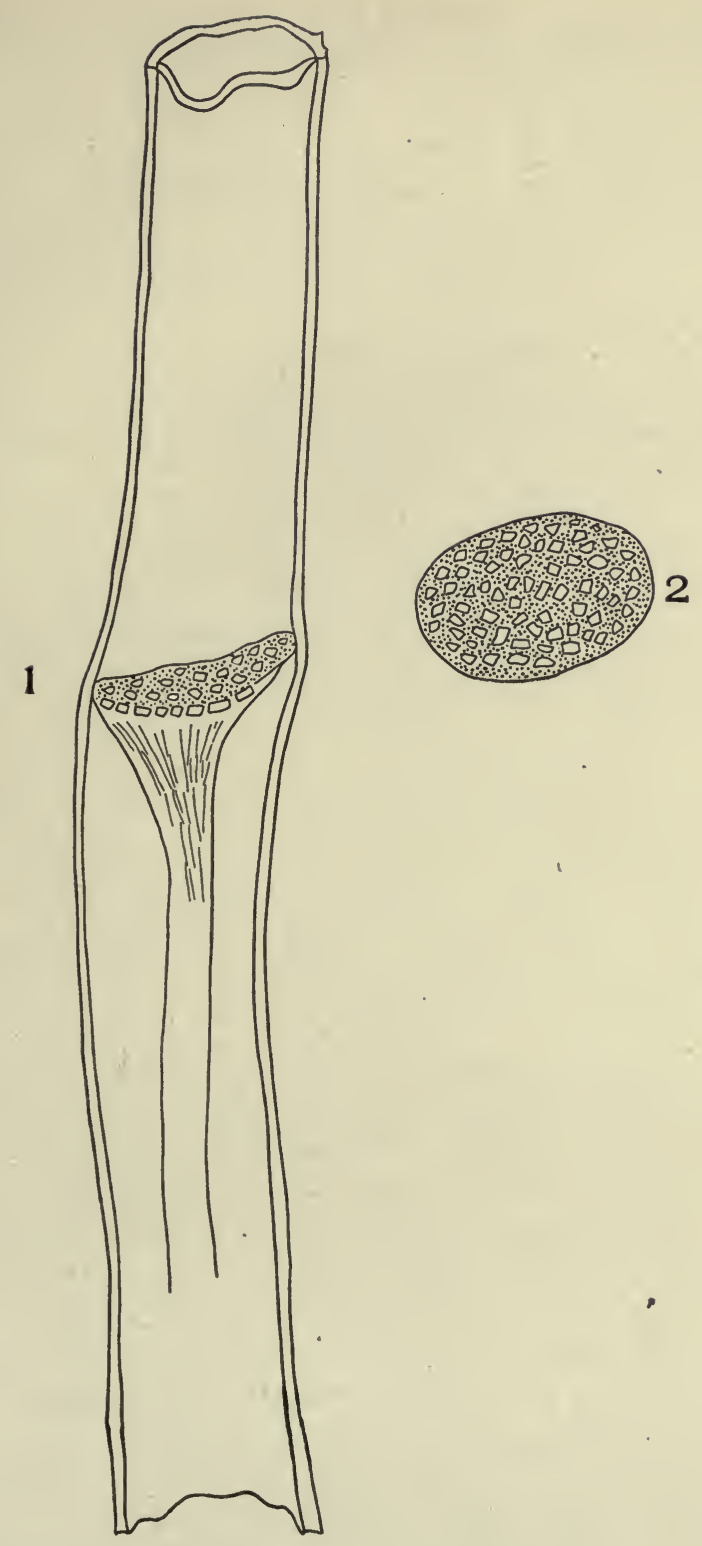

I. Longitudinal section of sieve tube (Cucurbita pepo, L.).

2. Cross-section of sieve tube just above an end wall-sieve plate. 
walls. This thickened part of the porous end walls of two sieve cells is called the sieve plate, and it may be placed in an oblique or a horizontal position.

In a longitudinal section the sieve tubes are seen to be slightly bulging at the sieve plate, and through the pores extend protoplasmic strands. The strands are united on the upper and lower side of the sieve plate to form the protoplasmic strands of the living sieve tubes and the callus, layers of dried plants. This callus is frequently yellowish in color, and in all cases is separated from the cell wall. In certain plants the sieve plate occurs on the side walls of the sieve tubes in contact with other sieve tubes.

\section{SIEVE PLATE}

Sieve plates on cross-section (Plate 46, Fig. 2) are polygonal in outline, and the pores are either round or angled. Large sieve tubes and sieve plates occur in pumpkin stem; but, almost without exception, in drug plants the sieve tubes are small and the sieve plate is inconspicuous. When the drug is powdered, the sieve tubes break up into undiagnostic fragments. When studying sections of the plants, the extent, size, and arrangement of the sieve tubes must always be noted.

\section{MEDULLARY BUNDLES, RAYS, AND CELLS}

\section{Function}

The medullary ray cells are the lateral conducting cells of the plant. They conduct outwardly the water and inorganic salts brought up from the roots by the vessels and tracheids; and they conduct inwardly toward the centre of the stem the food material manufactured in the leaves and brought down by the sieve cells. The medullary rays thus distribute the inorganic and organic food to the living cells of the plant, and they conduct the reserve food material to the storage cells, and, lastly, they function in certain plants as storage cells.

\section{Occurrence}

The form, size, wall structure, and the distribution of the medullary ray bundles, rays, and cells are best ascertained by 
studying: first, the cross-section of the plant; secondly, the radial section; and, thirdly, the tangential section.

Students should be careful to distinguish between the medullary ray bundle, the medullary ray, and the medullary ray cell. In some plants the bundles are only one cell wide, but in other plants the medullary ray bundle is more than one cell wide, frequently several cells wide.

\section{THE MEDULLARY RAY BUNDLE}

The medullary ray bundle is made up of a great many medullary ray cells. These bundles (Plate ro6, Fig. 5) are of variable length, height, and width. The bundles are isolated, and they occur among and separate the other cells of the plants in which they occur. Tangential sections show the medullary ray bundle in cross-section. Such sections are lens-shaped, and they show both the width and the height of the medullary ray bundle. The length of the medullarr ray bundle is shown in cross-sections.

\section{THE MEDULLARY RAY}

The medullary ray (Plate 47 ) is a term used to indicate that part of a medullary ray bundle which is seen in crosssections and in radial sections. In cross-sections the length of the ray will be as great as the length of the bundle, and the width of the ray will be as great as the width of the medullary ray bundle at the point cut across. In longitudinal sections the medullary ray will differ in height according to the thickness of the bundle at the point cut.

When the medullary rays extend from the centre of the stem to the middle bark, they are termed primary medullary rays; when they extend from the cambium circle to the middle bark, they are termed secondary medullary rays. As the plant grows, the diameter of the organ becomes greater and the number of medullary rays are increased. In each of these cases the medullary rays may be one or more than one cell wide, according to whether the medullary ray bundle is one or more than one cell wide. Even in the same plant the width of the medullary rays will vary if the bundle is more than one cell wide, according to width of the medullary ray bundle at the point cut across. 
PLATE 47

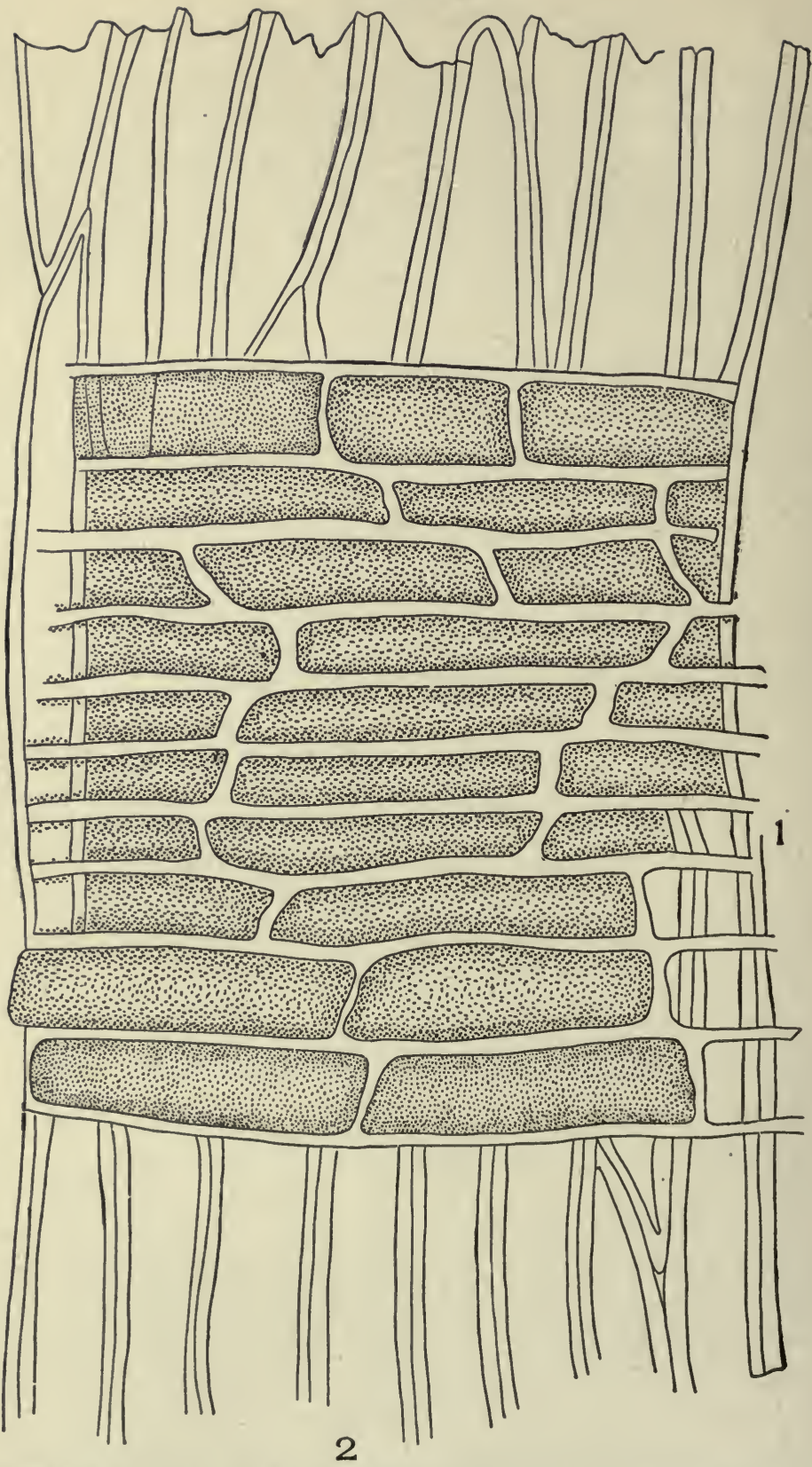

Radial Longitudinal Section of White Sandal wood (Santulum album, L.)

I. Medullary ray.

2. Wood fibres and wood parenchyma. 
On cross-section the medullary rays are seen to vary greatly. In many plants they are more or less straight radial lines, as in quassia (Plate 105, Fig. 2); while in other plants they form wavy lines where they bend or curve around the conducting cells, as in piper methysticum, kava-kava (Plate 48, Fig. A).

In the study of powdered drugs the radial view of the medullary rays is most frequently seen.

In a perfect radial section (Plate I07, Fig. 2) the medullary rays are seen as tiers of cells in contact throughout their long diameter, and they run at right angles to the long diameter of the other cells. This view of the rays shows the length and height of the medullary ray. In logwood the rays are often forty cells high. In powdered barks, woods (Plate 47), and woody roots the radial view of the medullary rays is frequently diagnostic.

In guaiacum officianale wood the medullary rays are one cell wide on cross-section, and up to six cells high on the tangential section. In santalum album the rays are from one to three cells wide on cross-section, and up to six cells high on tangential section. In the greater number of plants the rays are more than one cell wide.

\section{THE MEDULLARY RAY CELL}

The medullary ray cell (Plate 48 , Fig. I) is one of the individual cells making up the medullary ray bundle and the medullary ray.

The cross-sections of the cells which are seen in tangential sections show the cells to be mostly circular in outline when they occur in the central portion of medullary ray bundles of more than two cells in width; but they are more irregular in outline when the medullary ray bundle is only one cell wide. Even the cells of the three or more cell-wide bundles have irregular, outlined cells at the ends of the bundle and on the sides in contact with the other tissues.

The length and height of the medullary ray cell are shown in radial sections; while the width and length of the medullary ray cells are shown in cross-sections. 


\section{Structure of Cells}

The structure of the individual cells forming the medullary rays differs greatly in different plants, but is more or less constant in structure in a given species.

The medullary rays of the wood usually have strongly pitted side and end walls, while the medullary rays of most barks are not at all, or only slightly, pitted. In most plants the cells are of nearly uniform size. Frequently, however, the cells vary in size in a given ray, as shown in the cross-section of kava-kava.

\section{Arrangement of the Cells in a Ray}

The union of any two cells in a ray is also of importance. In quassia the medullary ray cells have oblique end walls, so that on cross-section the line of union between two cells is an oblique wall. In most plants the medullary ray cells have blunt or square or oblique end walls, so that the line of union is a straight line.

In most plants the cells are much longer than broad, but the cells of sassafras bark are nearly as broad as long.

The walls of the cortical medullary ray cells and the medullary rays of most roots and stems of herbs are composed of cellulose; while the walls of medullary ray cells occurring in woods are frequently lignified.

There is a great variation in the character of the cell contents of medullary rays. In white pine bark (Plate 48, Fig. $\mathrm{BI}$ ) are deposits of tannin; in quassia wood, starch; in canella alba, rosette crystals of calcium oxalate, etc.

\section{LATEX TUBES}

Living latex tubes, like sieve tubes, have a layer of protoplasm lining the walls, and, in addition, have numerous nuclei. In drug plants the nuclei are not distinguishable, but the protoplasm is always clearly discernible.

Latex tubes function both as storage and as conducting cells. They, like the sieve tubes, contain proteid substances chiefly, yet frequently starch is found. The cells bordering the latex tubes absorb from them, as needed, the soluble food material. While our knowledge concerning the function of latex in some 


\section{PLATE 48}
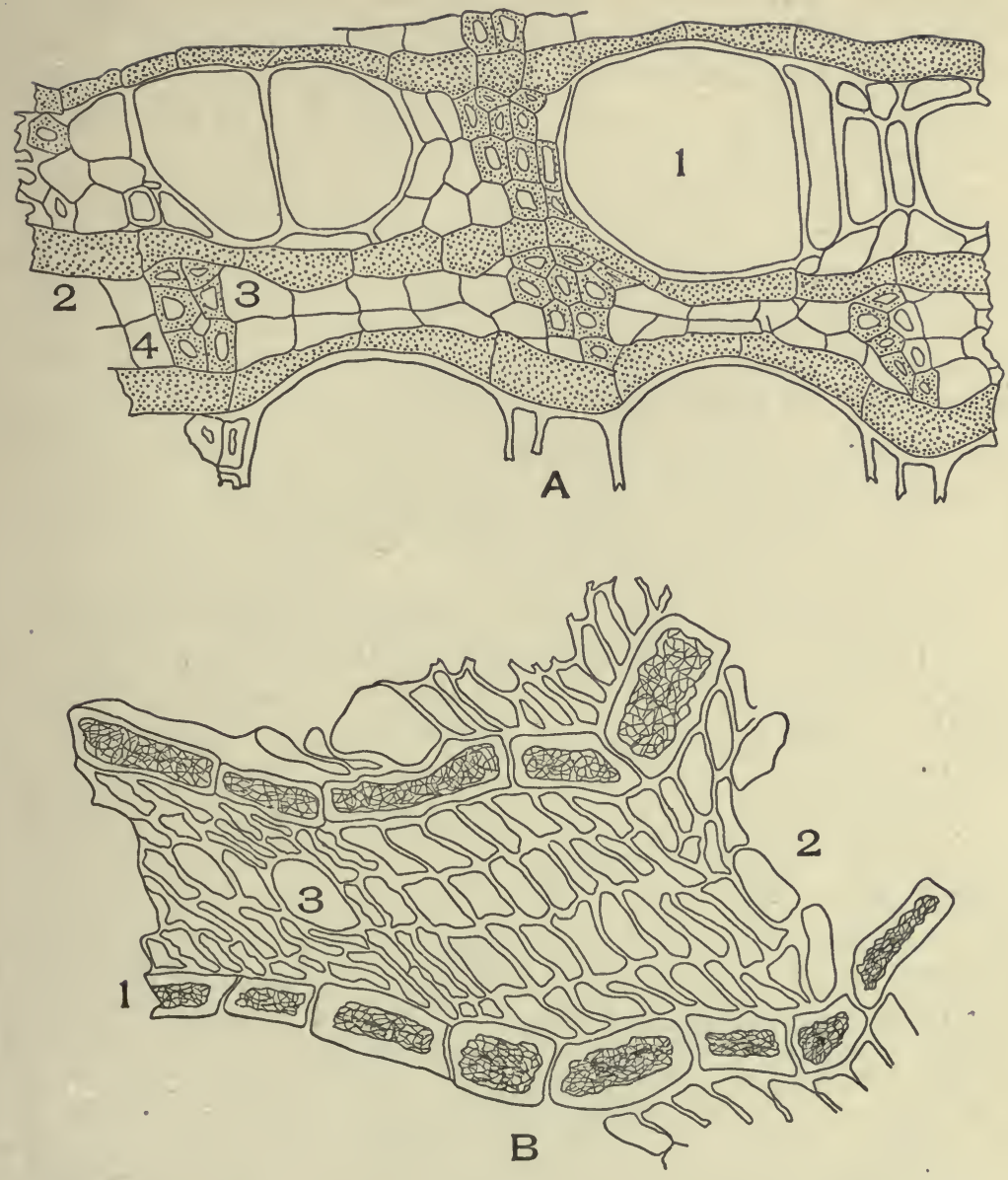

A. Cross-section of kava-kava root (Piper methysticum, Forst., f.).

I. Unequal diameter medullary ray cells.

2. Vessels.

3. Wood parenchyma.

4. Wood fibres.

B. Cross-section of white pine bark (Pinus strobus, L.).

I. Wavy medullary rays with tannin.

2. Parenchyma cells.

3. Sieve cells. 
plants is meagre, still in other plants it is practically certain that the latex is composed of nutritive substances which are utilized by the plant as food. In certain other plants the latex appears to be used as a means of resisting insect attacks and as a protection against injury.

There are two types of latex tubes common to plants, namely, latex cells and latex vessels. Latex tubes developing from a single cell do not differ materially from a latex tube originating from the fusion of several cells. In each case the latex tube branches to such an extent that it bears no resemblance to ordinary cells. It would seem that the ultimate branches are formed and develop in much the same manner as root hairs-that is, by a growing tip of the branch. A mature plant may therefore have latex tubes with almost numberless branches (Plate 50, Fig. I) and be of very great length.

The branches of latex tubes develop in such an irregular manner that it is possible to obtain a cross and a longitudinal section of the latex tubes by making a cross-section of stem. Such a section is shown in the drawing of the cross-section of the rhizome of black Indian hemp (Plate 49, Fig. B).

The color of the latex in medicinal plants varies from a gray white in papaw (carica papaya), aromatic sumac, black Indian hemp, and bitter root, to white in the opium poppy, light orange in celandine, and deep orange in bloodroot (Plate 50, Fig. 2). In each of these cases it is the latex which yields the important medicinal products.

\section{PARENCHYMA}

The larger amount of plant tissue is composed of parenchyma cells. These cells vary from square to oblong, or they may be irregular and branched. The end walls are square or blunt, and the wall is composed of cellulose, with the exception of the wood parenchyma, which has lignified walls.

There are seven characteristic types of parenchyma cells: (I) cortical parenchyma, (2) pith parenchyma, (3) wood parenchyma, (4) leaf parenchyma, (5) aquatic plant parenchyma, (6) endosperm parenchyma, (7) phloem parenchyma.

Parenchyma cells, cortical, pith, aquatic plant, leaf, flower, 


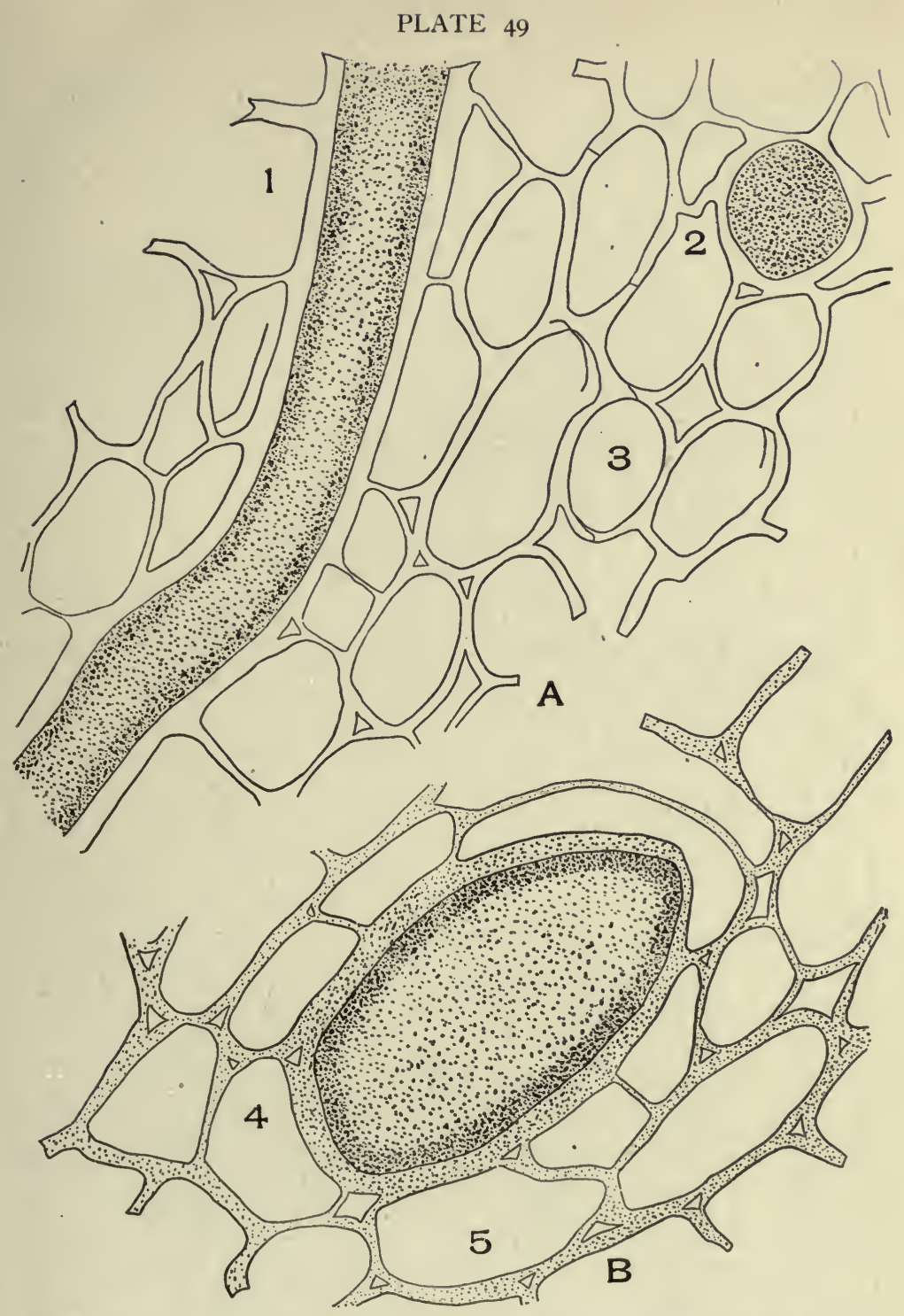

A. Cross-section of black Indian hemp (Apocynum cannabinum, L.).

I. Longitudinal section of a latex tube.

2. Cross-section of latex tube.

3. Parenchyma.

$B$. Cross-section of a part of black Indian hemp root.

4. Cross-section of a large latex tube.

5. Parenchyma. 


\section{PLATE 50}

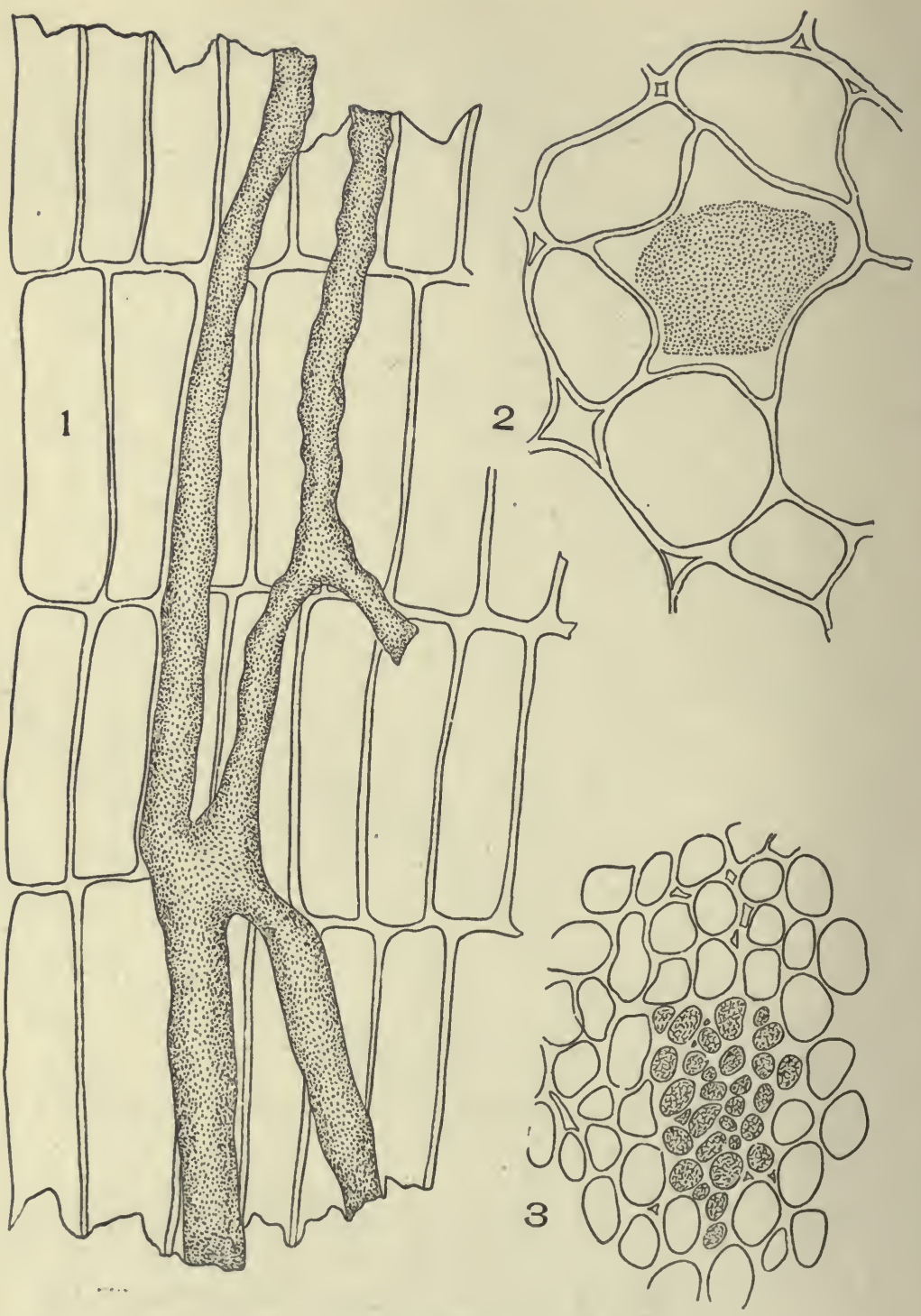

LATEX VESSELS

I. Radial-longitudinal section of dandelion root (Taraxacum officinale, Weber).

2. Cross-section of sanguinaria root (Sanguinaria canadensis, L.).

3. Cross-section of dandelion root. 
and endosperm, conduct in all directions-upward, downward, and laterally. The direction of conduction depends upon the needs of the different cells forming the plant. The fluids pass from the cell with an abundance of cell sap to the cell with less cell sap. In this wall all cells are provided with food.

Parenchyma cells conduct water absorbed by the roots and soluble carbohydrate material chiefly.

The walls of all the different types of parenchyma cells are composed of cellulose with the exception of the wood parenchyma cells, the walls of which are lignified. The end walls of nonbranched parenchyma cells and the cell terminations of branched cells are very blunt.

\section{CORTICAL PARENCHYMA}

Cortical parenchyma (Plate $5 \mathrm{I}$ ) differs greatly in size, thickness of the walls, and arrangement. A study of the longitudinal sections of different parts of medicinal plants reveals the fact that the cortical parenchyma cells form superimposed layers in which the end walls are either parallel, in which case tre arrangement resembles that of several rows of boxes standing on end, or the end walls of the cells alternate with each other, in which case the arrangement is similar to that of the arrangement of the bricks in a building.

In certain plants the cortical parenchyma cells are long and narrow and rectangular in shape, while in other plants the cells, although still rectangular in outline, are very broad and approach the square form.

All typical cortical parenchyma cells have uniformly thickened non-pitted walls. In most barks the parenchyma cells beneath the bark are elongated tangentially, but are very narrow radially. The cells are always arranged around intercellular spaces, which vary from triangular, quadrangular, etc., according to the number of cells bordering the intercellular space.

\section{PITH PARENCHYMA}

Pith parenchyma (Plate 52) differs from cortical parenchyma cells chiefly in the character of the walls, which are usually thicker and always pitted. 

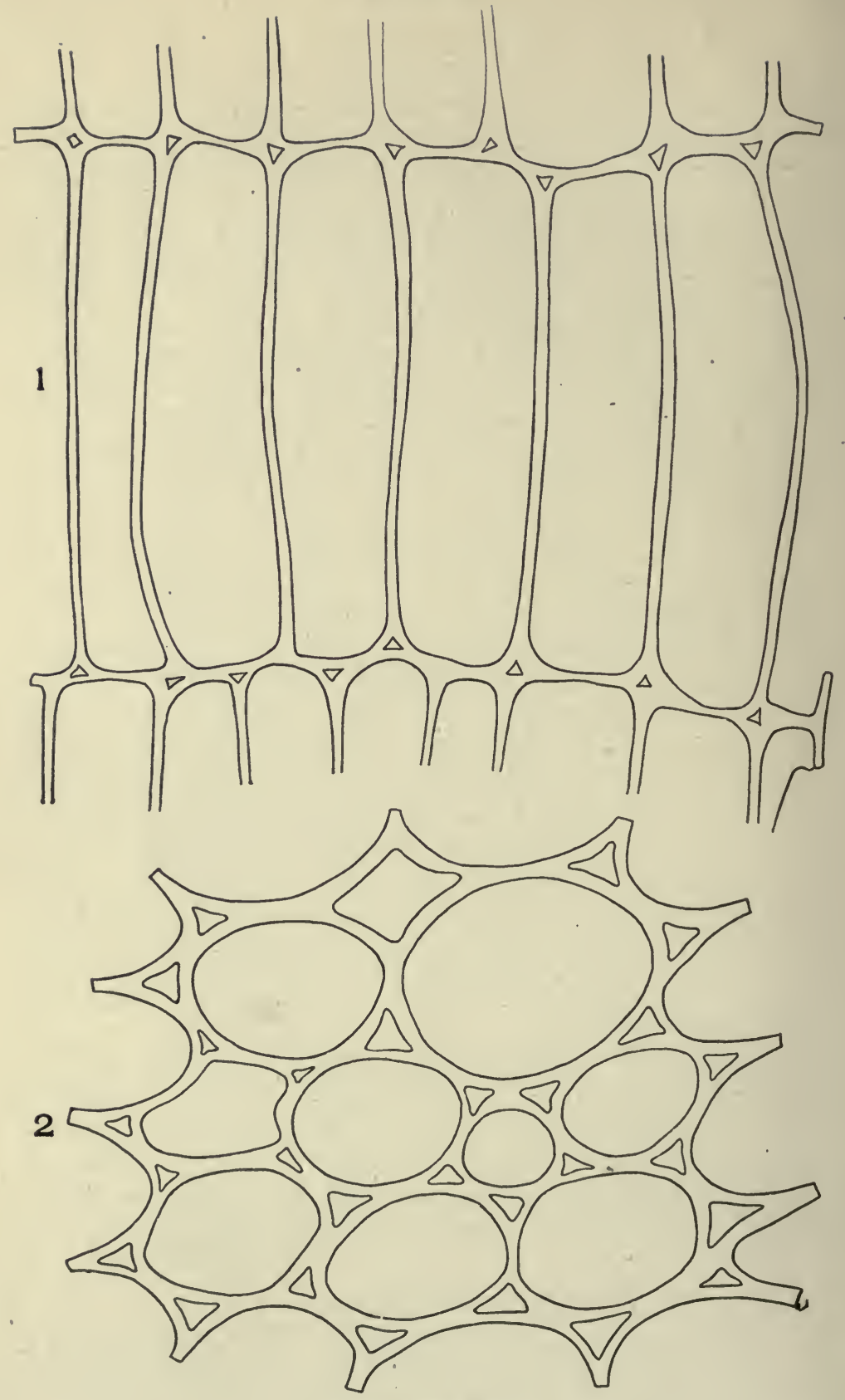

Parenchyma Cells

I. Longitudinal section of the cortical parenchyma of celandine root (Chelidonium majus, L.) 2. Cross-section of the cortical parenchyma of sarsaparilla root (Smilax officinalis, Kunth). 
PLATE 52
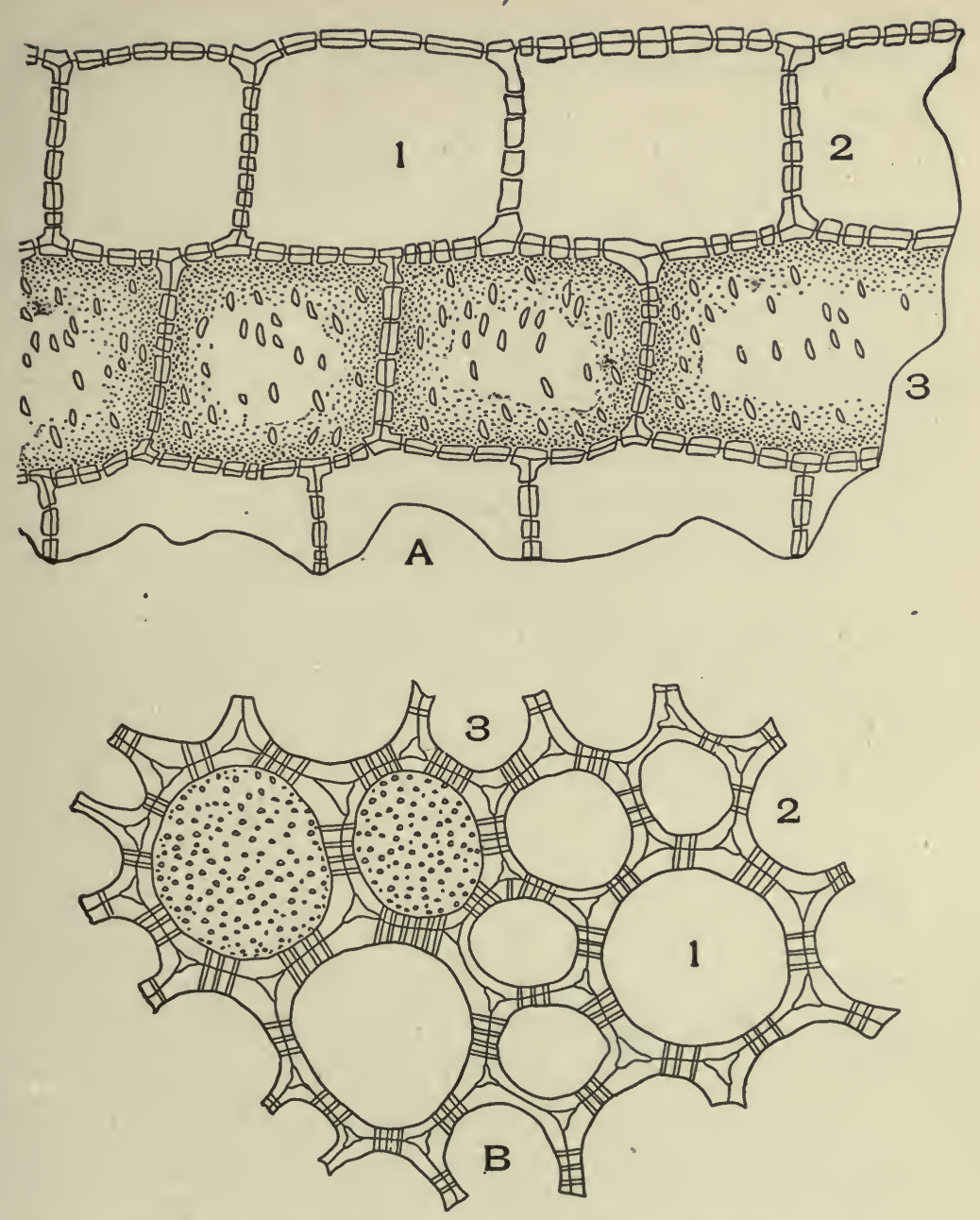

A. Longitudinal section of the pith parenchyma of grindelia stem (Grindelia squarrosa, [Pursh] Dunal).

r. Cell cavity.

2. Cross-section of the porous end wall.

3. Surface view of the porous side wall.

$B$. Cross-section of the pith parenchyma of grindelia stem.

I. Cell cavity.

2. Porous walls.

3. Pitted end walls 


\section{LEAF PARENCHYMA}

The parenchyma cells (Plate I09, Fig. I) of leaves, of flower petals, and the parenchyma cells of some aquatic plants are branched; that is, each cell has more than two cell terminations. These cell terminations are frequently quite attenuated and usually very blunt. Such a cell structure provides for a greater amount of intercellular space and a maximum exposure of surface. This arrangement makes it possible for the parenchyma cells of the leaf to absorb more readily the enormous amount of carbon dioxide needed in the photosynthetic process.

\section{AQUATIC PLANT PARENCHYMA}

The parenchyma of aquatic plants (Plate 59) has large intercellular spaces formed by the chains of cells.

\section{WOOD PARENCHYMA}

Wood parenchyma (Plate ro5, Fig. 3) cells are the narrowest parenchyma cells occuring in the plant. Their walls are always lignified and strongly pitted, and in some cases the end walls common to two cells are obliquely placed.

\section{PHLOEM PARENCHYMA}

Phloem parenchyma (Plate ıoo, Fig. 8) cells are usually associated with sieve cells. They are very long, narrow, and have thin, non-pitted walls. The thinness of the walls undoubtedly enables the cells to conduct diffusible food substance more quickly than the cortical parenchyma cells.

\section{PALISADE PARENCHYMA}

Palisade parenchyma of leaves is of the typical parenchyma shape and the end walls are placed nearly on a plane, even when more than one layer is present. The cells are verv small, however, and the walls are very thin and non-pitted. 


\section{CHAPTER VI}

\section{AERATING TISSUE}

The aerating tissue of the plant performs a threefold function: first, it permits the exchange of gases during photosynthesis; secondly, it permits the entrance of oxygen and the exit of carbon dioxide during respiration; and, thirdly, it permits the exit of the excess of water absorbed by the plant.

The above functions are carried on by the stomata, the water-pores, the lenticels, and the intercellular spaces of the plant. The stoma functions as the chief channel for the passage of $\mathrm{CO}_{2}$-laden air into the leaf and of oxygen-laden air from the leaf to the atmosphere. The stoma also functions as an organ of transpiration, since through the stoma a large part of the excess water of the plant passes off into the air.

\section{WATER-PORES}

In certain plants the primary epidermis is provided with openings resembling stomata, but unlike stomata the orifice remains open, and instead of being located on the upper or lower surface of the leaf, they are located on the margin of leaves immediately outward from the veins. Water is given off to the atmosphere from these openings. Such an opening is usually designated as a water-pore.

\section{STOMATA}

The chief external openings of the epidermis of leaves, of herbs, and of young wood stems are known as stomata. Surrounding the stoma are two cells known as guard cells.

Guard cells differ greatly in form, in size, in arrangement, in occurrence, in association, in abundance (Plates 53, 54, and 55 ), and in color. The guard cells surrounding the stoma vary in form from circular to lens-shaped. In most leaves the outiine 


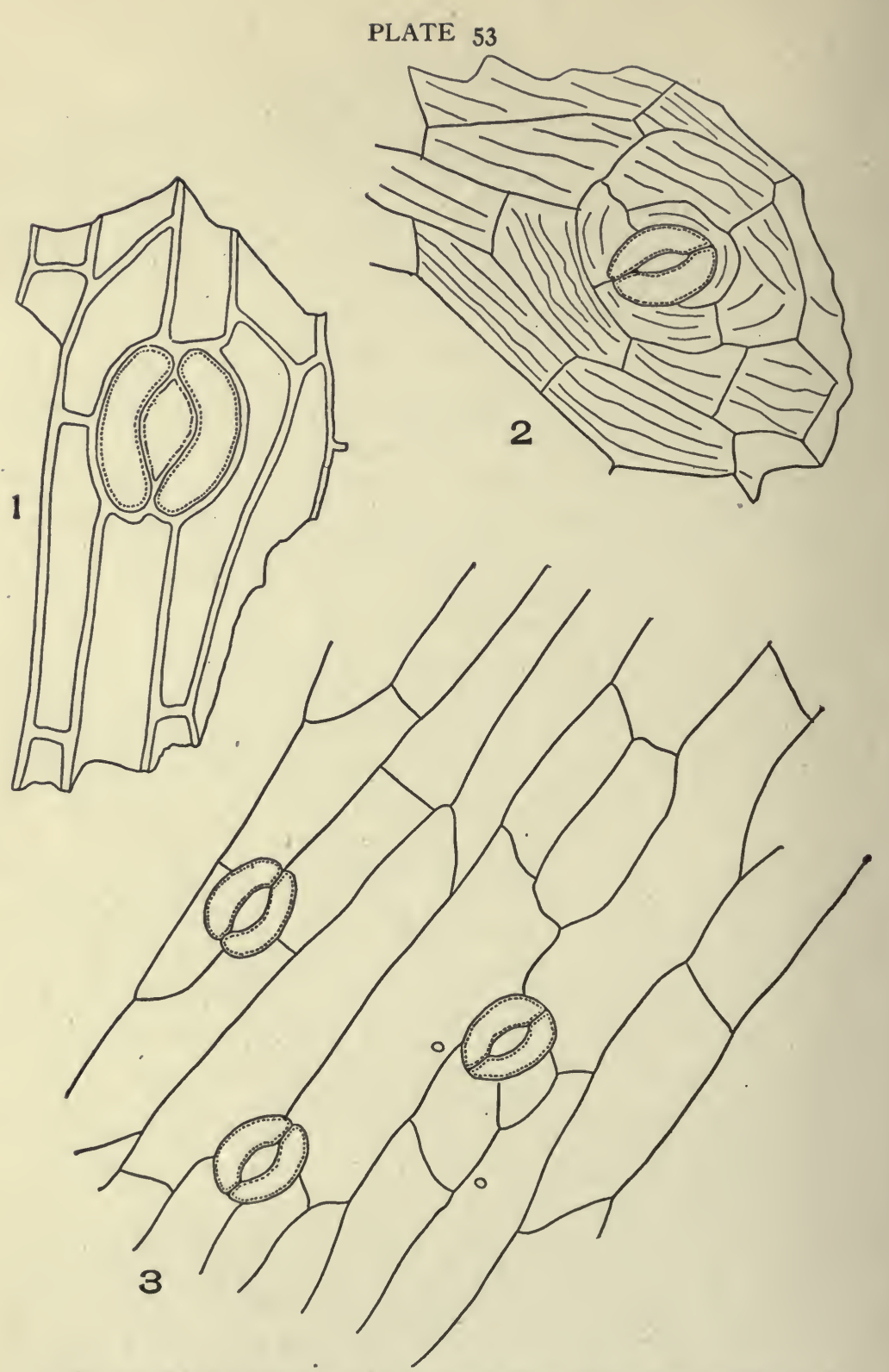

I. Stoma and surrounding cells of aconite stem (Aconitum napellus, L.).

2. Stoma and angled striated walled surrounding cells of peppermint stem (Mentha piperita, L.). 3. Stoma and elongated surrounding cells of lobelia stem (Lobelia inflata, L.). 
PLATE 54
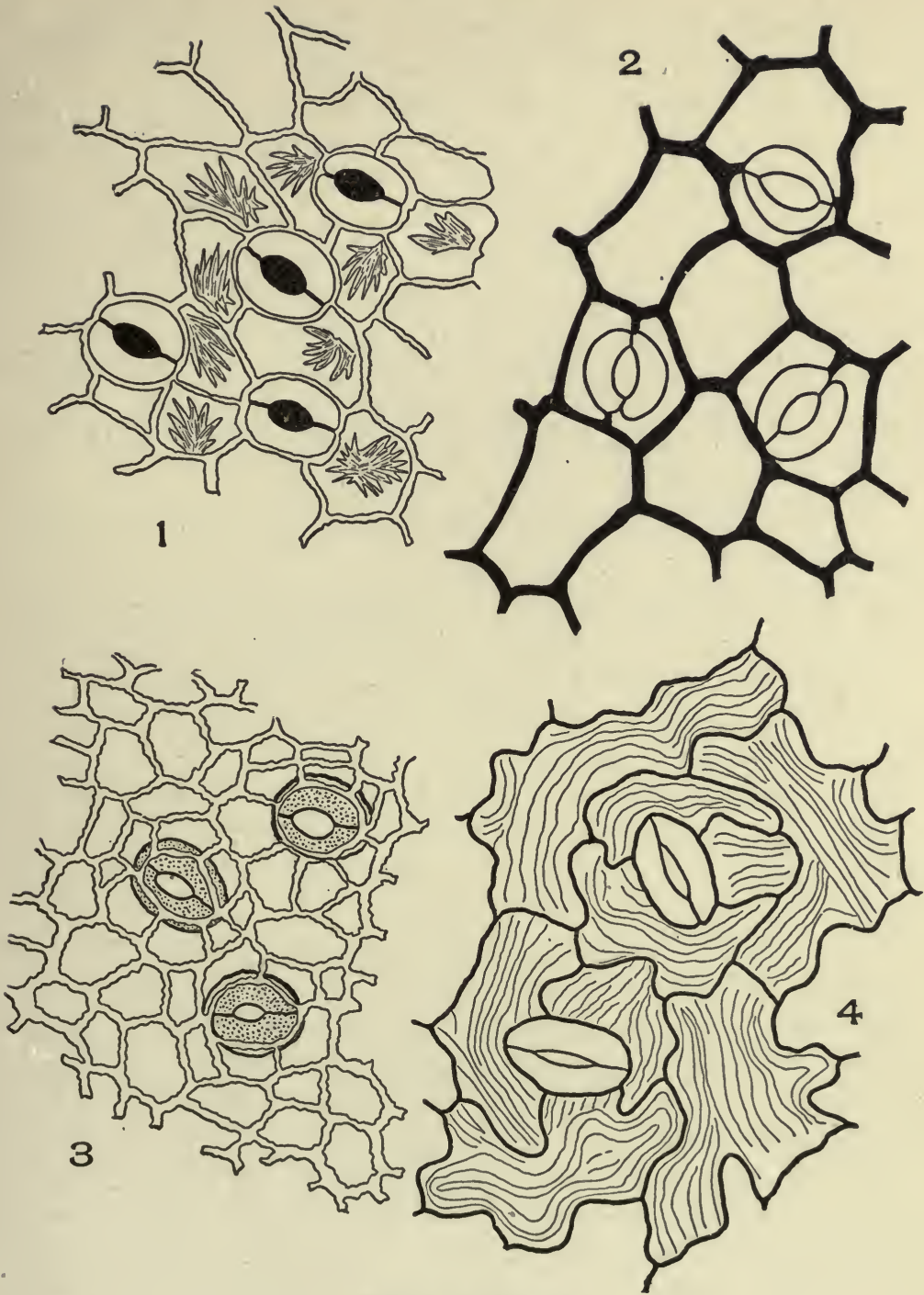

Types of Stoma

I. Under epidermis of short buchu (Barosma betulina, [Berg.] Bartling and Wendl., f.) showing stoma and deposits of hesperidin.

2. Under epidermis of Alexandria senna (Cassia acutifolia, Delile) showing stoma and thick-angled walled surrounding cells.

3. Upper epidermis of eucalyptus leaf (Eucalyptus globulus, Labill.) showing sunken stoma and slightly beaded walled surrounding cells.

4. Under epidermis of belladonna leaf (Atropa belladonna, L.) showing stoma and wavy, striated, walled epidermal cells. 
of the guard cells is rounded or has a curved outline; but in a few cases the guard cells have angled outlines.

The arrangement of the surrounding cells of the stoma is one of the most important characteristics of the different leaves. As a rule the number of surrounding cells about a stoma is constant for a given species. In senna leaves (Plate 54, Fig. 2) there are normally two surrounding cells about each guard cell, while in coca there are four (Plate 55, Fig. I). In senna the long diameter of the surrounding cells is parallel to the long diameter of the guard cells; but in coca the long diameter of two surrounding cells is at right angles to the long diameter of the guard cells, while two cells are parallel to the long diameter of the guard cells.

In most leaves there are more than two cells around the guard cells.

The form and size of the surrounding cells must always be considered. In most leaves they are variable in size and form.

Guard cells occur first, even with the surface of the leaf (Plate 56, Fig. A); secondly, above the surface of the leaf (Plate $5^{6}$, Fig. B); and, thirdly, below the surface of the leaf. (Plate 56, Fig. C). Only one of the above types occurs in a given species of plant. That is, plants with stomata above the surface of the leaf do not have stomata on a level with or below the leaf surface.

The number of stomata on a given surface of a different leaf varies considerably.

In many of the medicinal leaves stomata occur only on the under surface of the leaf. In other leaves stomata occur on both surfaces of the leaf; but in such cases there are a greater number on the under surface.

In certain leaves the long diameter of the guard cells is parallel to the length of the leaf; in other cases the long diameter of the stoma is arranged at right angles to the length of the leaf.

In other leaves the arrangement is still more irregular, the guard cells assuming all sorts of positions in relation to the length of the leaf.

The relation of the stoma to surrounding cells is best shown in cross-sections of the leaf. In powders the relationship of the stoma to the surrounding cells is, however, readily ascer- 
PLATE 55

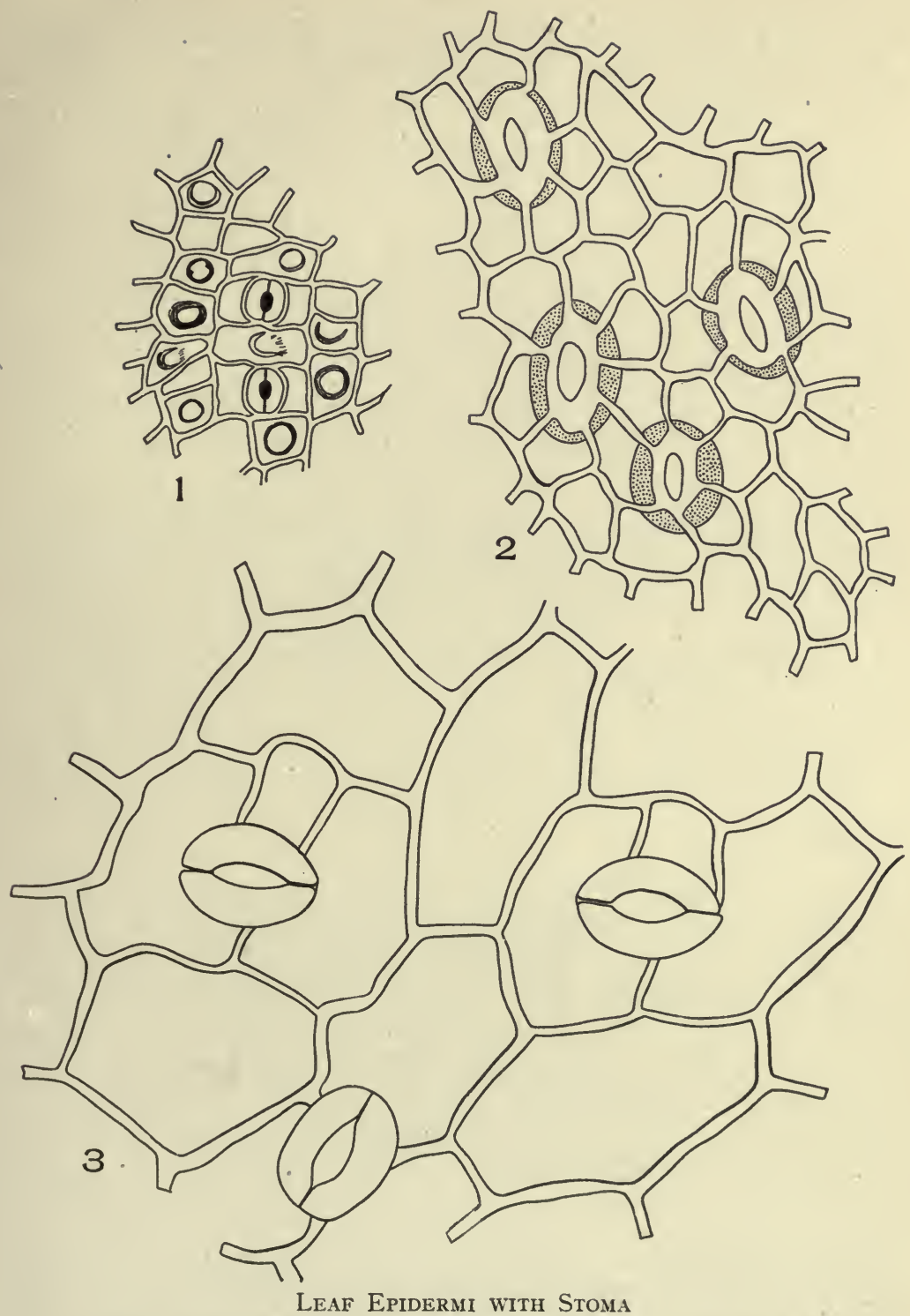

I. Under epidermis of coca leaf (Erythroxylon coca, Lam.) with stoma on a level with the surface.

2. Under epidermis of false buchu (Marrubium peregrinum, L.) with stoma below the level of the surface.

3. Upper epidermis of deer tongue (Trilisia odoratissima, [IValt.] Cass.) with stoma above the leaf surface. 


\section{PLATE 56}
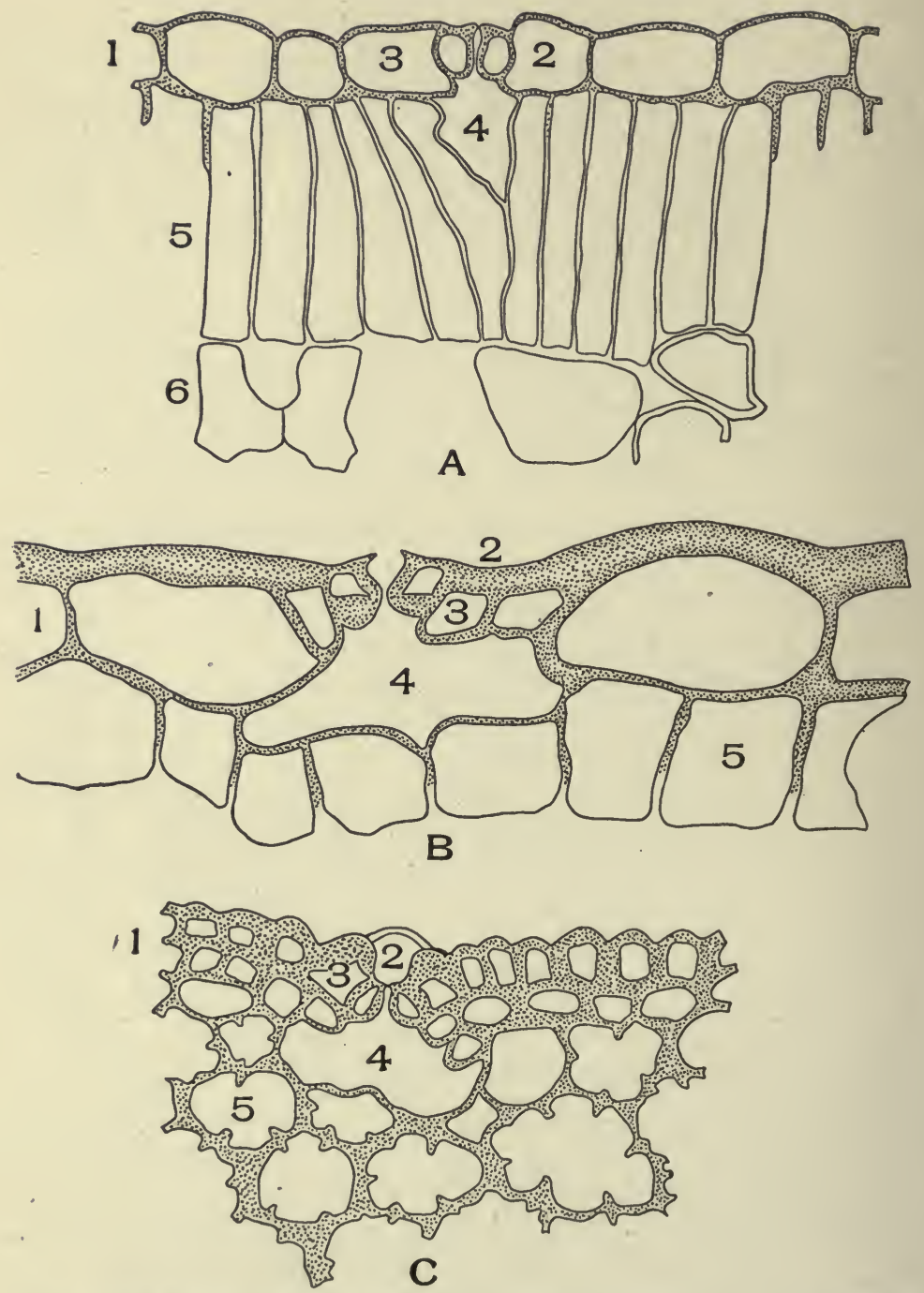

A. Cross-section of belladonna leaf (Atropa belladonna, L.). I, Epidermal cells; 2, Guard cells even with the leaf surface; 3, Surrounding cells; 4, Air space below the guard cells; 5, Palisade cells; 6, Mesophyll cells. B. Crosssection of deer tongue leaf. I, Epidermal cells; 2, Guard cells above the surface of the leaf; 3, Surrounding cells; 4, Air space below the guard cells; 5, Hypodermal cells. C. Cross-section of white pine leaf (Pinus strobus, L.). I, Epidermal and hypodermal cells; 2, Guard cells below the leaf surface; 3, Surrounding cells; 4, Air space below the guard cells; 5, Parenchyma cells with projecting inner walls. 
tained. If the guard cells come in focus first, they are above the surface; if the guard cells and the surrounding cells come in focus at the same time, the stomata are even with the surface; if the stomata come in focus after the surrounding cells, they are below the surface of the leaf. The relationship of the stoma to the surrounding cells should always be ascertained, not only in cross-sections of the leaf, but also in powders.

There is the greatest possible variation in the size of guard cells. This fact must always be kept in mind when studying leaves. This variation in the size of the guard cells is clearly illustrated by coca, senna, and by deer's-tongue. In coca the stomata are very small; in senna they are larger; while in deer's-tongue the stomata are very large.

The width and length of the stoma or opening between the guard cells are of a character which must not be overlooked. Generally speaking, those leaves which have large guard cells will have correspondingly large stomata.

The guard cells usually contain chloroplasts showing various stages of decomposition.

In bay-rum leaf the guard cells are of a bright reddishbrown color, but in most leaves the guard cells are colorless.

\section{LENTICELS}

Lenticels are small openings occurring in the bark of plants. The lenticels bear the same relationship to the stem that the stomata do to the leaves. Lenticels, like stomata, have a threefold function-namely, exchange of gases in photosynthesis, in respiration, and the giving off of water.

Lenticels are macroscopically as well as microscopically important. When unmagnified the lenticels are circular, lensshaped, or irregular in outline. They are arranged in parallel longitudinal lines or parallel transverse lines, or they are irregularly scattered. The latter is the usual arrangement. In most cases they are elevated slightly above the surface of the bark. In root barks particularly the lenticels stand out prominently from the surface of the bark and in many cases appear stalked.

The color of the lenticels differs greatly in the different 
plants. In acer spicatium they are brown; in witch-hazel they are gray; in xanthoxylium they are yellowish; and lastly, the number of lenticels occurring in a given surface of the bark should always be considered.

On cross-sections the lenticel (Plate 57, Fig. 2) is seen to have a central depressed portion made up of loosely arranged cells. Bordering the cavity are typical cork cells. The cork cells immediately surrounding the lenticels are usually darker in color, and many of the cells are partly broken down.

The size of lenticels will vary according to the type of the lenticel. In studying sections more attention should be paid to the character of the cells forming the lenticels than to the size of the lenticel.

On cross-section the intercellular spaces (Plate 58 ) are triangular, quadrangular, or irregular. The spaces between equal diameter parenchyma cells is triangular if three cells surround the space, and quadrangular if four cells surround the space. etc. These spaces are in direct contact with similar spaces that traverse the tissue at right angles to its long axis.

The branched mesophyll cells of the leaf and aquatic plant parenchyma (Plate 59) are arranged around irregular cavities. In leaves and aquatic plants these spaces run parallel to the long axis of the organ.

In each of the above cases the cavity is formed by the separation of the cell walls. There is still another type of irregular cavities which is formed by the dissolution or tearing apart of the cell walls. Such cavities are found in the stems and roots of many herbs.

The pith cells in the stems of many herbs become torn apart during the growth of the stem, with the result that large irregular cavities are formed. These cavities are usually filled with circulatory air.

In the stems of conium, cicuta, angelica, and other larger herbaceous stems the pith separates into layers. When a longitudinal section is made of such a stem it is seen to be composed of alternating air spaces and masses of pith parenchyma.

The intercellular spaces are very large in leaves where enormous quantities of carbon dioxide are vitalized in photosynthesis. 
PLATE 57

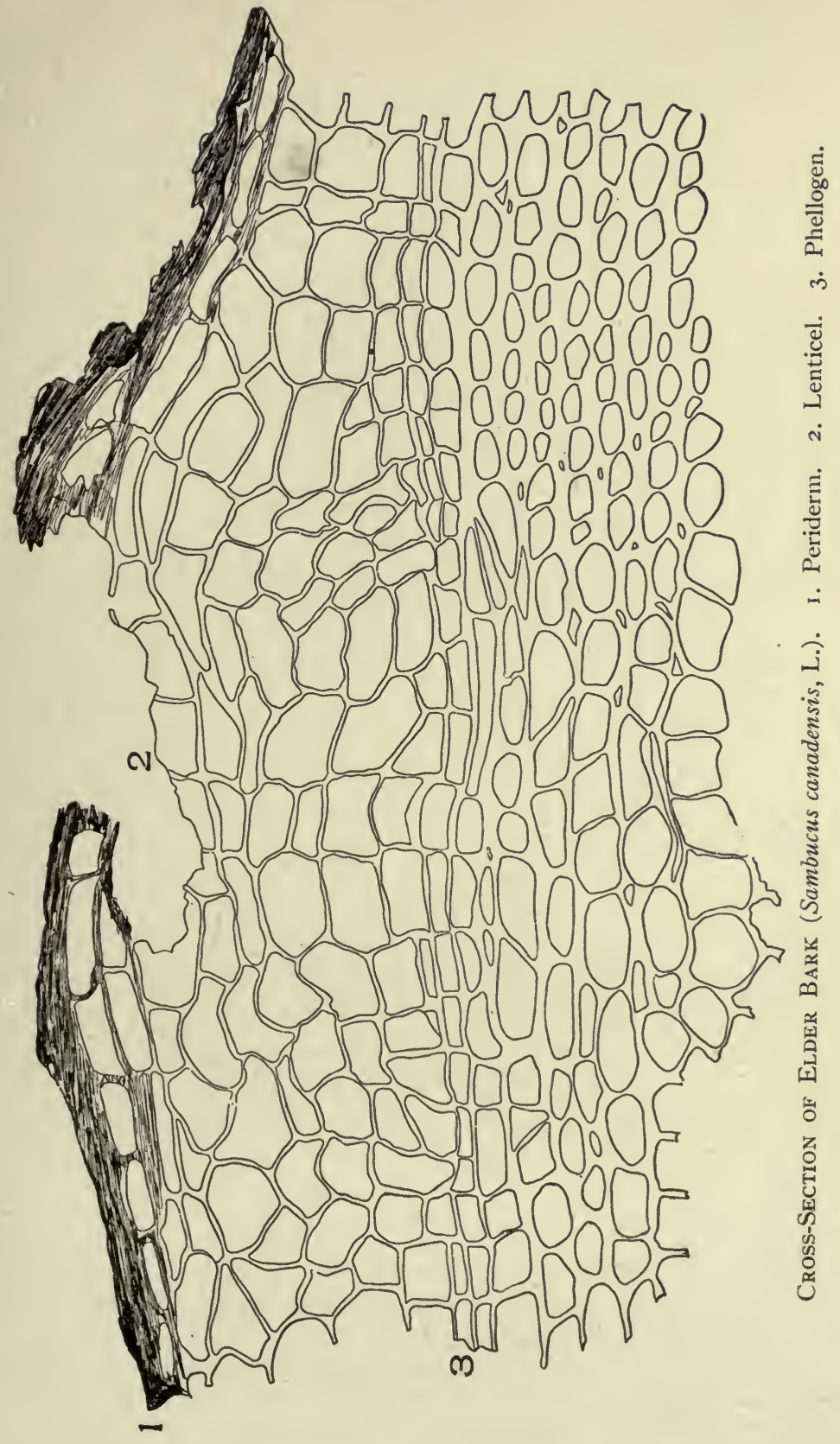




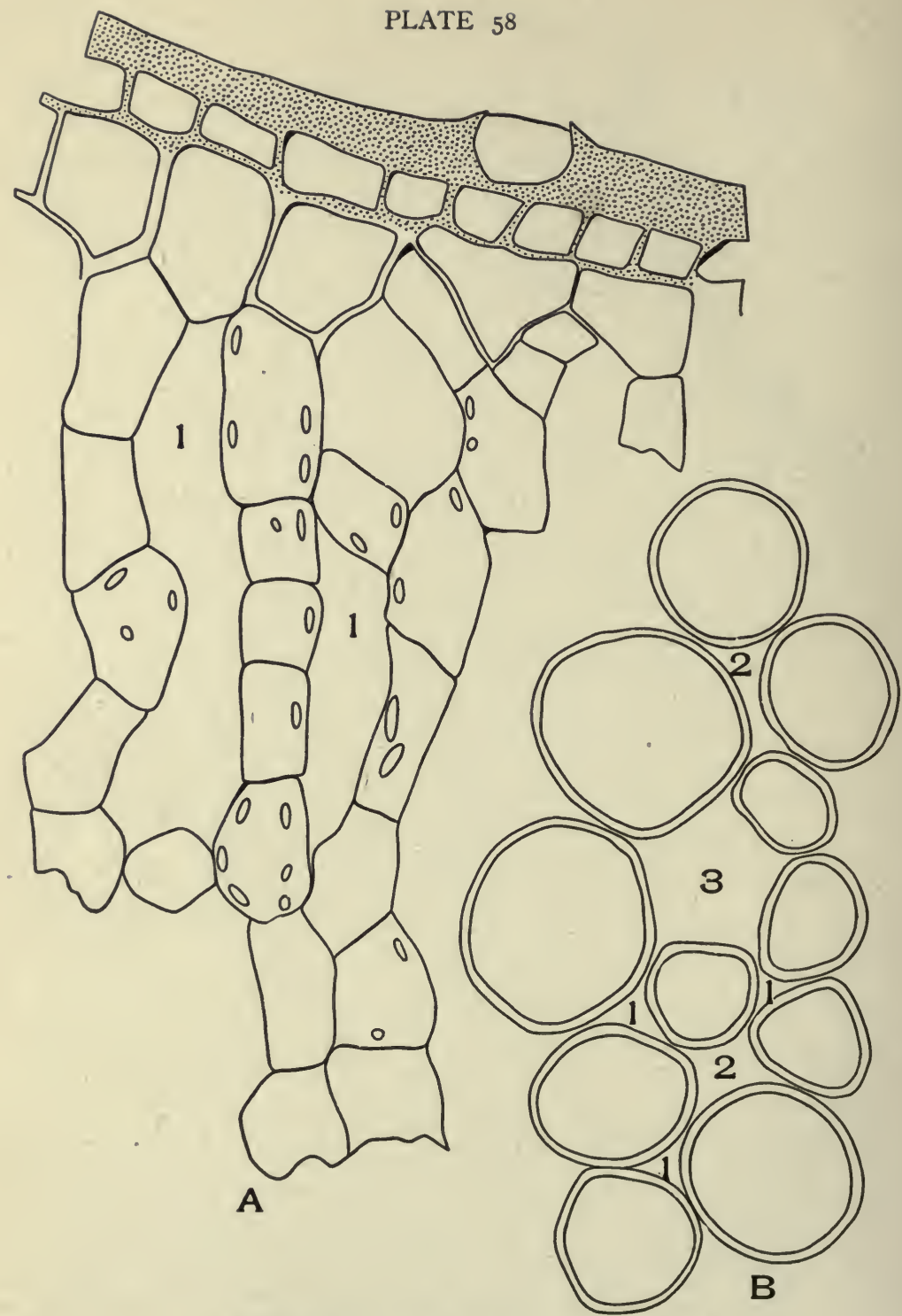

INTERCELlular Air Spaces

A. Cross-section of uva-ursi leaf (Arctostaphylos uva-ursi, [L.] Spreng.). I. Irregular intercellular air spaces.

B. Cross-section of the cortical parenchyma of sarsaparilla root (Smilax officinalis, Kunth). I, Triangular intercellular spaces; 2, Quadrangular intercellular air spaces; 3, Pentagular intercellular air spaces. 


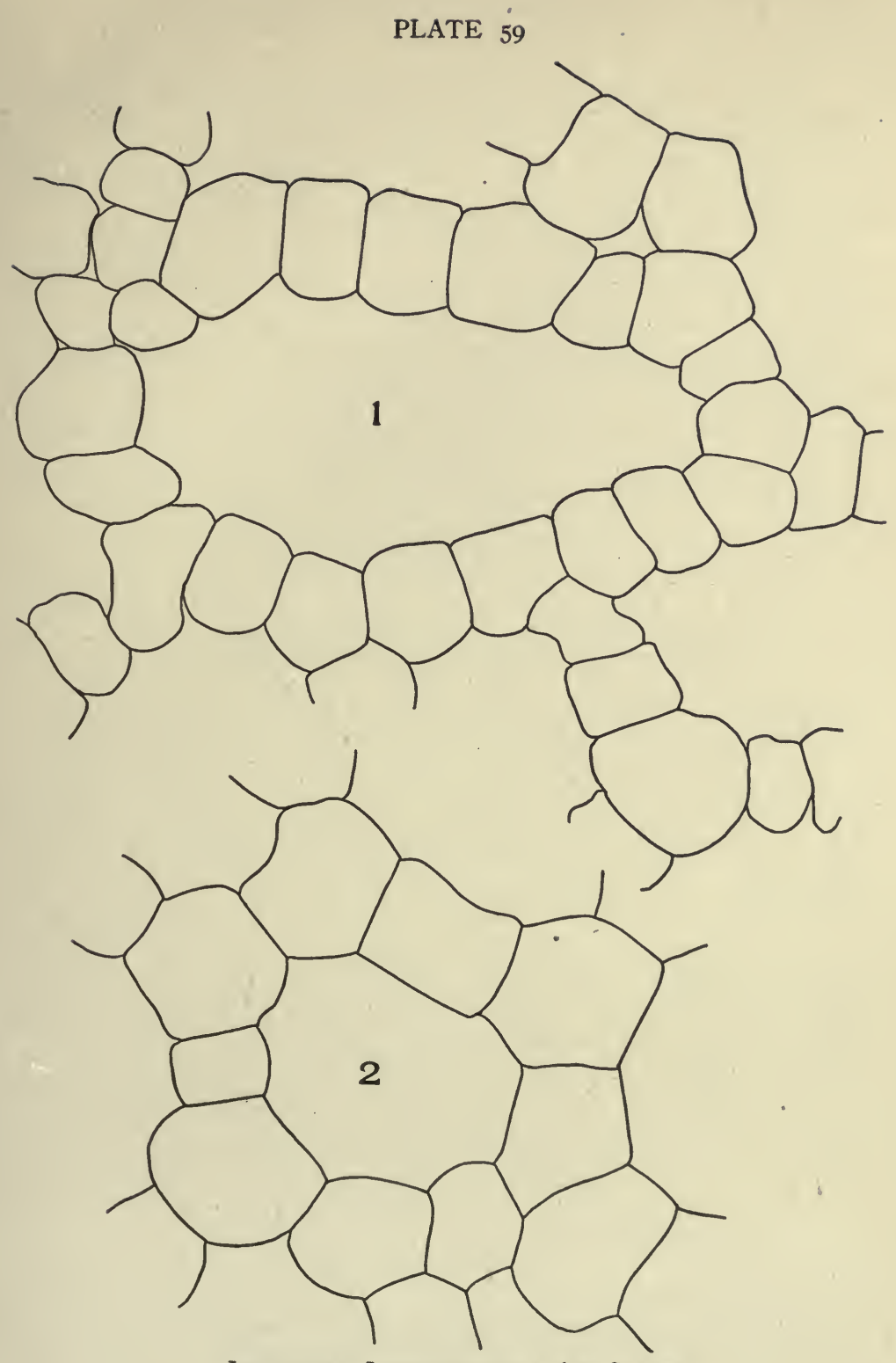

-Irregular Intercellular Air Spaces

I. Skunk-cabbage (Symplocarpus fatidus, [L.] Nutt.)

2. Calamus rhizome (Acorus calamus, L.). 
In the rhizome of calamus and other aquatic plants the intercellular spaces are very large. The cells of these plants are arranged in the form of branching chains of cells which thus provide for large intercellular spaces.

The cells of the middle layer of flower petals, like the mesophyll of leaves, is loosely arranged owing to the peculiar branching form of the cells.

Seeds and fruits contain, as a rule, few or no intercellular spaces. 


\section{CHAPTER VII}

\section{SYNTHETIC TISSUE}

Under synthetic tissue are grouped all tissues and cells which form substances or compounds other than protoplasm. Such compounds are stored either in special cavities or in the cells of the plant, as the glandular hairs; internal secreting cavities of barks, stems, leaves, fruits, seeds, and flowers; photosynthetic cells or cells with chlorophyll, and the parenchymatic cells which form starch, sugar, fats, alkaloids, etc.

\section{PHOTOSYNTHETIC TISSUE}

The most important non-glandular synthetic tissue is the photosynthetic tissue, which is composed of the chlorophyllbearing cells of the plant. These are the so-called green cells of leaves, of stems of herbs, of young woody stems, and in the older woody stems of plants like wild cherry, birch, etc. The greater part of the tissue of leaves is composed of chlorophyllbearing cells.

Leaves collectively constitute the greatest synthetic manufacturing plant in the world, because the green cells of the leaf produce most of the food of men and animals. The two compounds utilized in the manufacture of food are carbon dioxide $\left(\mathrm{CO}_{2}\right)$ and water $\left(\mathrm{H}_{2} \mathrm{O}\right)$. These two compounds are combined by chlorophyll through the agency of light into starch. Chemically this reaction may be expressed as follows:

$$
6 \mathrm{CO}_{2}+{ }_{5} \mathrm{H}_{2} \mathrm{O}={ }_{2} \mathrm{C}_{6} \mathrm{H}_{10} \mathrm{O}_{5}+6 \mathrm{O}_{2} \text {. }
$$

During the day a large quantity of starch is formed. At night through the action of a ferment the excess of starch remaining in the leaf is converted into sugar $\left(\mathrm{C}_{6} \mathrm{H}_{12} \mathrm{O}_{6}\right)-\mathrm{C}_{6} \mathrm{H}_{10} \mathrm{O}_{5}+$ $\mathrm{H}_{2} \mathrm{O}=\mathrm{C}_{6} \mathrm{H}_{12} \mathrm{O}_{6}$. In this form it is distributed to the living cells of the plant. The presence or absence of starch in leaves is easily ascertained by placing the leaf in hot alcohol to remove 
the chlorophyll, and by adding Lugol's solution. If starch is present, the contents of the cells will become bluish black; but if no starch is present, the cells remain colorless.

\section{GLANDULAR TISSUE}

The glandular tissue of the plant is divided into two groups, according to where it occurs. These groups are, first, external glandular tissue, and secondly, internal glandular tissue. The most important external glandular tissue is composed of the glandular hairs. These are divided into two groups: first, unicellular; and secondly, multicellular glandular hairs.

\section{UNICELLULAR GLANDULAR HAIRS}

The unicellular glandular hairs are either sessile or stalked.

Sessile unicellular hairs occur in digitalis leaves.

Stalked unicellular hairs of digitalis are shown on Plate 6o, Fig. 2.

Unicellular uniseriate stalked glandular hairs occur on the stems of the common house geranium (Plate 6I, Fig. 2), on the leaves of butternut, the leaves and stems of marrubium peregrinum (Plate 98, Fig. 5), and in arnica flowers. The stalk varies from two to ten cells; in eriodictyon the cells vary from four to eight cells.

Unicellular multiseriate stalked glandular hairs are not of common occurrence.

\section{MULTICELLULAR GLANDULAR HAIRS}

Multicellular glandular hairs are divided into two groups: first, sessile; and secondly, stalked hairs.

- Multicellular sessile glandular hairs occur on the leaves of peppermint (Plate 60, Fig. 3), horehound (Plate 97, Fig. 7), and in hops (Plate 60, Fig. 4). In each of these hairs there are eight secretion cells.

Stalked glandular hairs are divided into two groups: first, uniseriate stalked; and secondly, multiseriate stalked glandular hairs.

Multicellular uniseriate stalked glandular hairs occur on the leaves of tobacco (Plate 6I, Fig. 4), belladonna (Plate 6r, 


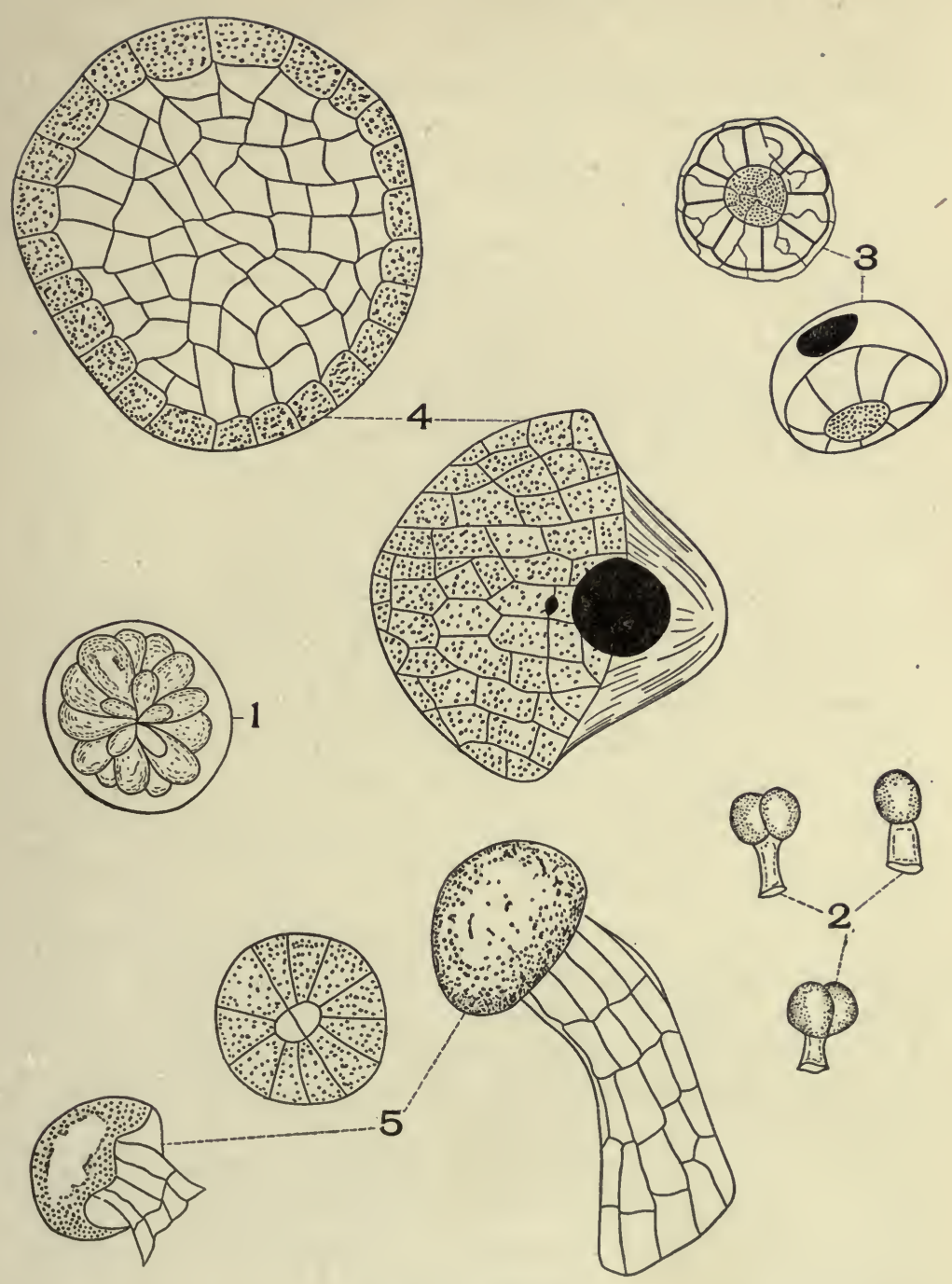

Glandular Hairs

I. Kamala (Mallotus philippinensis, [Lam.] [Muell.] Arg.).

2. Digitalis leaf (Digitalis purpurea, L.).

3. Peppermint leaf (Mentha piperita, L.).

4. Lupulin.

5. Cannabis indica leaf (Cannabis sativa, L.). 
Fig. I), and digitalis (Plate 60, Fig. 2), and of the fruit of rhus glabra.

Multicellular multiseriate stalked glandular hairs occur on the stems and leaves of cannabis indica (Plate 6o, Fig. 5).

In the glandular hair of kamala (Plate 6o, Fig. I) the number of secretion cells is variable and papillate in form, and the cuticle is separated from the secretion cells.

In the glandular hair of hops the outer wall or cuticle is torn away from the secretion cells, and the cavity thus formed serves as a storage cavity. This distended cuticle of the hops shows the outline of the cells from which it was separated.

In the glandular hairs of the mints the secreted products (volatile oils) are stored between the secretion cells and the outer detached cuticle. This cuticle is elastic, and it becomes greatly distended as the volatile oil increases in amount.

In many of the so-called glandular hairs, tobacco, belladonna geranium, etc., the synthetic products are retained in the glandular cells, there being no special cavity for their storage.

These hairs usually contain an abundance of chlorophyll.

The division wall of multicellular glandular hairs may be vertical, as in the two-celled hair of digitalis (Plate 60, Fig. 2); as in horehound (Plate 97, Fig. 6), and as in peppermint (Plate 6o, Fig. 3); in this case there are eight cells, and they form a more or less flat plate of cells.

In other hairs the division wall is horizontal; this produces a chain of superimposed secreting cells, as in some of the glandular hairs of belladonna leaf (Plate 6i, Fig. I), etc.

In other hairs the division walls are both vertical and horizontal, as in tobacco (Plate 6r, Fig. 4), henbane (Plate 6r, Fig. 3), belladonna (Plate 6r, Fig. I).

Other characters to be kept in mind in studying glandular hairs are the following: Color of cell contents; size of the cells, whether uniform or variable; character of wall, whether smooth or rough.

\section{SECRETION CAVITIES}

Secretion cavities are divided into three groups, according to the nature of the origin of the cavity: first, schizogenous cavities, which originate by a separation of the walls of the 


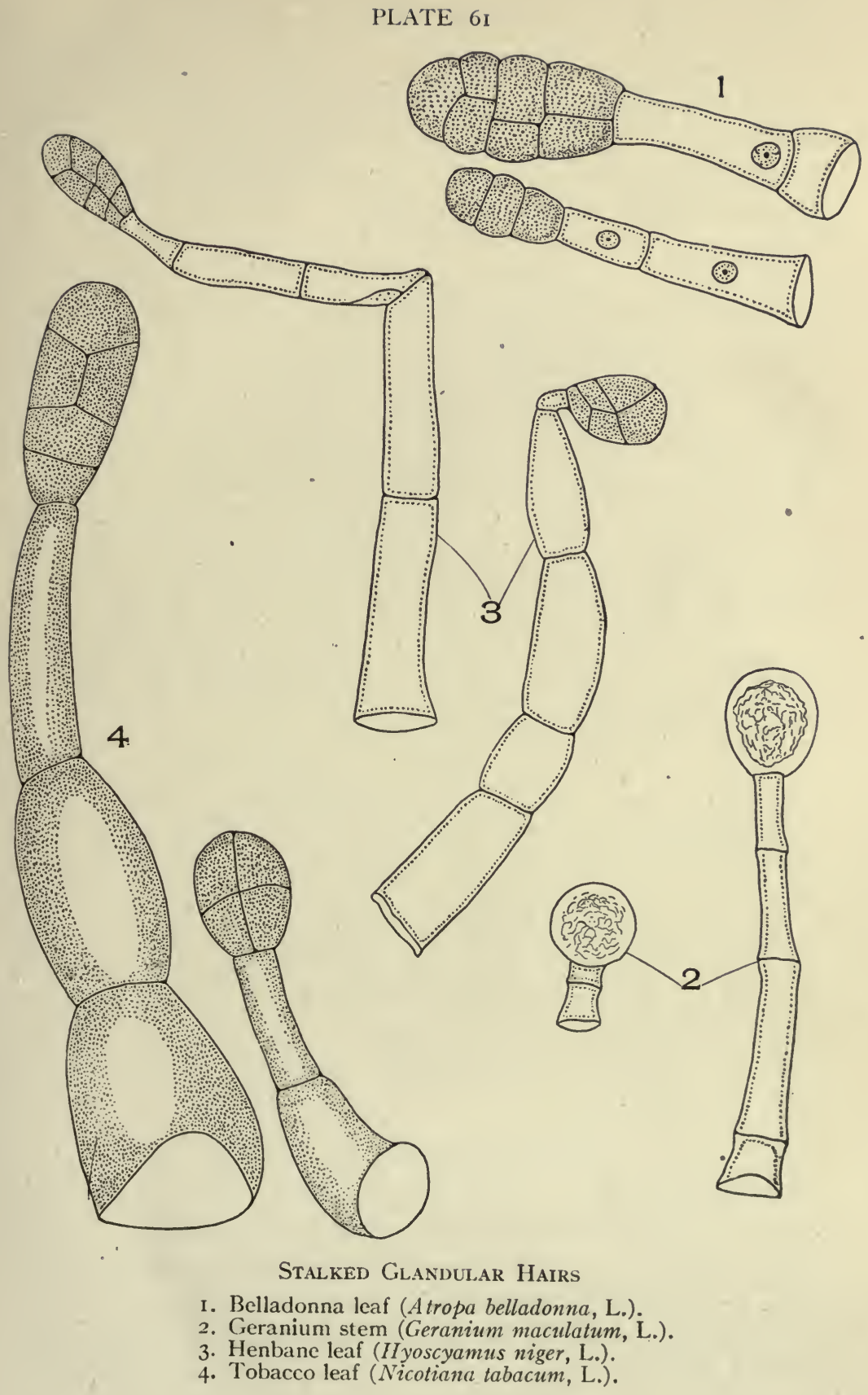


secretion cells; secondly, lysigenous cavities, which arise by the dissolution of the walls of centrally located secretion cells; and thirdly, schizo-lysigenous cavities, which originate schizogenously, but later become lysigenous owing to the dissolution of the outer layers of the secretion cells.

\section{SCHIZOGENOUS CAVITIES}

Schizogenous cavities occur in white pine bark (Plate 62, Fig. B). The cells lining the cavity are mostly tangentially elongated, and the wall extends into the cavity in the form of a papillate projection. Immediately back from these cells are two or three layers of cells which resemble cortical parenchyma cells, except that they are smaller and their walls are thinner.

- In white pine bark there is a single layer of thin-walled cells lining the cavity. Immediately surrounding the secretion cells is a single layer of thick-walled fibrous cells.

In klip buchu (Plate 63, Fig. B), as in white pine leaf (Plate 64 , Fig. B), there is a single layer of thin-walled secretion cells which are surrounded on three sides with parenchyma cells and on the outer side by epidermal cells.

\section{LYSIGENOUS CAVITIES}

Lysigenous cavities occur on the rind of citrus fruits-bitter and sweet orange, lemon, grapefruit, lime, etc., and in the leaves of garden rue, etc.

In bitter orange peel. (Plate 64, Fig. A) the cavity is very large, and the cells bordering the cavity are broken and partially dissolved. The entire cells back of these are white, thin-walled, tangentially elongated cells. There is a great variation in the size of these cavities, the smaller cavities being the recently formed cavities.

\section{SCHIZO-LYSIGENOUS CAVITIES}

Schizo-lysigenous cavities are formed in white pine bark and many other plants owing to the increase in diameter of the stem. In such cases the walls of the secreting cells break down. The resulting cavity resembles lysigenous cavities.

Unicellular secretion cavities occur in ginger, aloe, calamus, and in canella alba barb. 

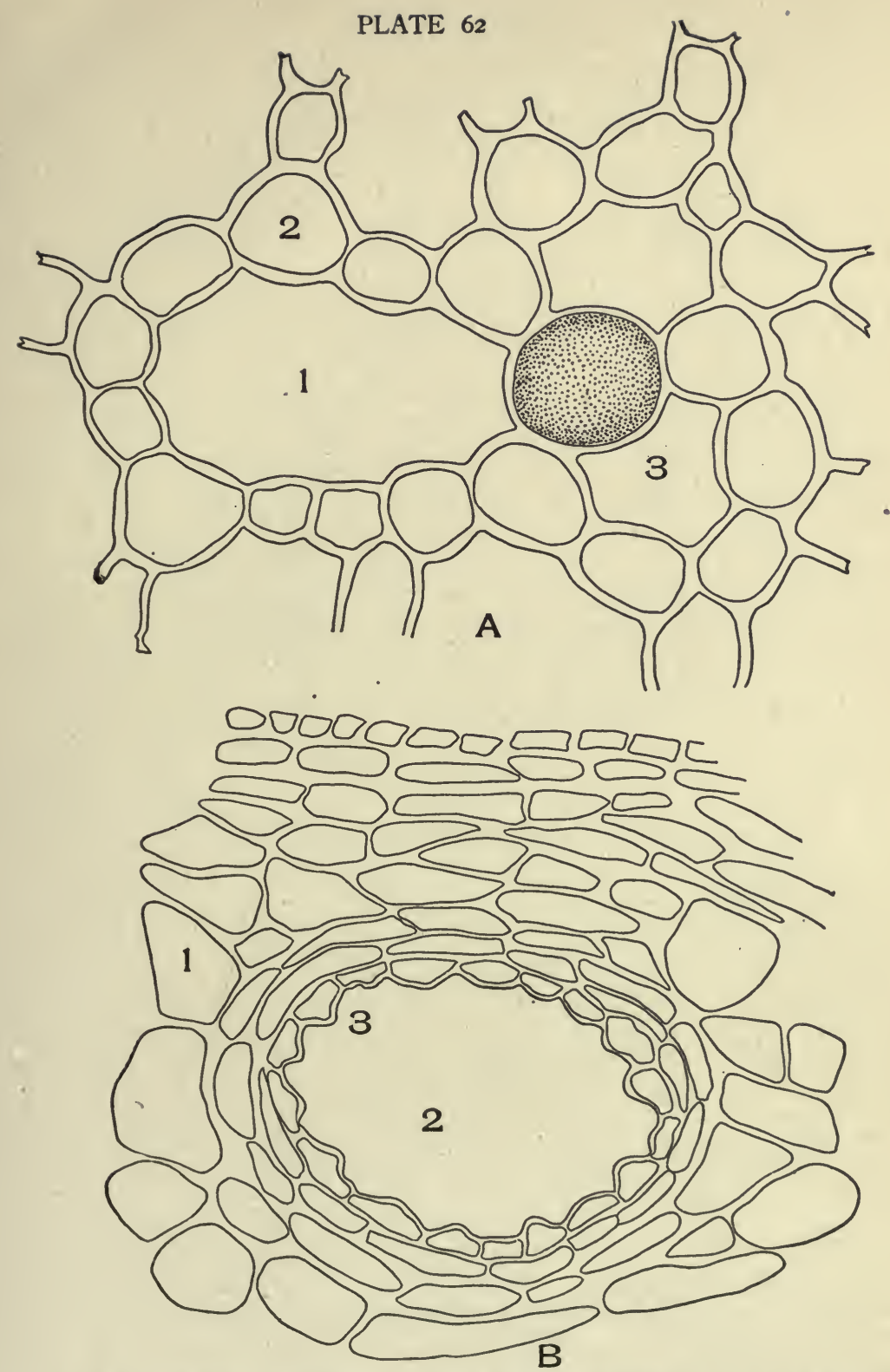

A. Cross-section of calamus rhizome" (Acorus calamus, L.)! I, Intercellular space; 2, Parenchyma cells; 3 , Secretion cavity. B. Cross-section of white pine bark (Pinus strobus, L.). I, Parenchyma; 2, Secretion cavity; 3 , Secretion cells. 
PLATE 63

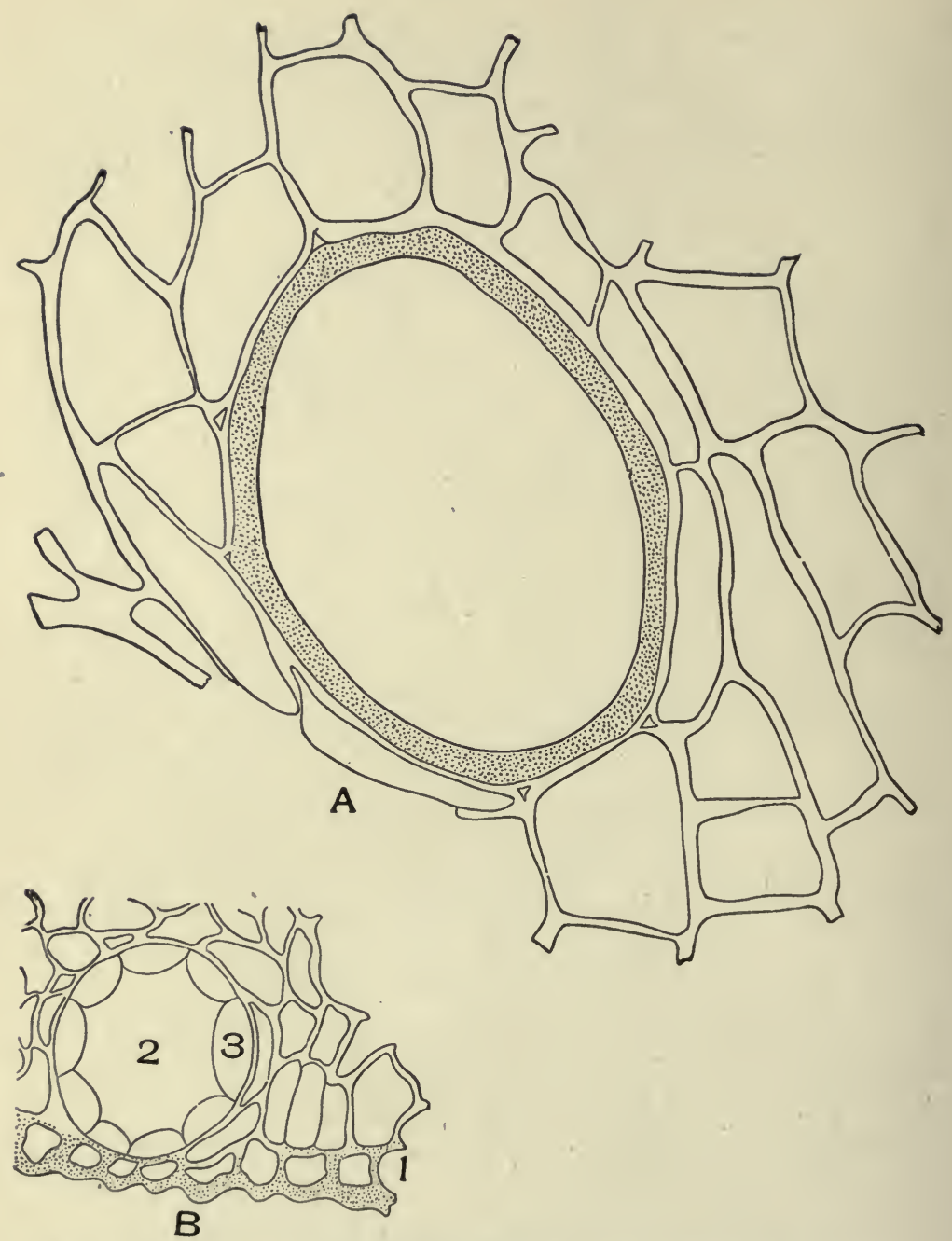

A. Cross-section of a portion of canella alba bark (Canella alba, Murr.). I. Excretion cavity.

$B$. Cross-section of a portion of klip buchu leaf.

I. Epidermal cells.

2. Secretion cavity.

3. Secretion cells. 

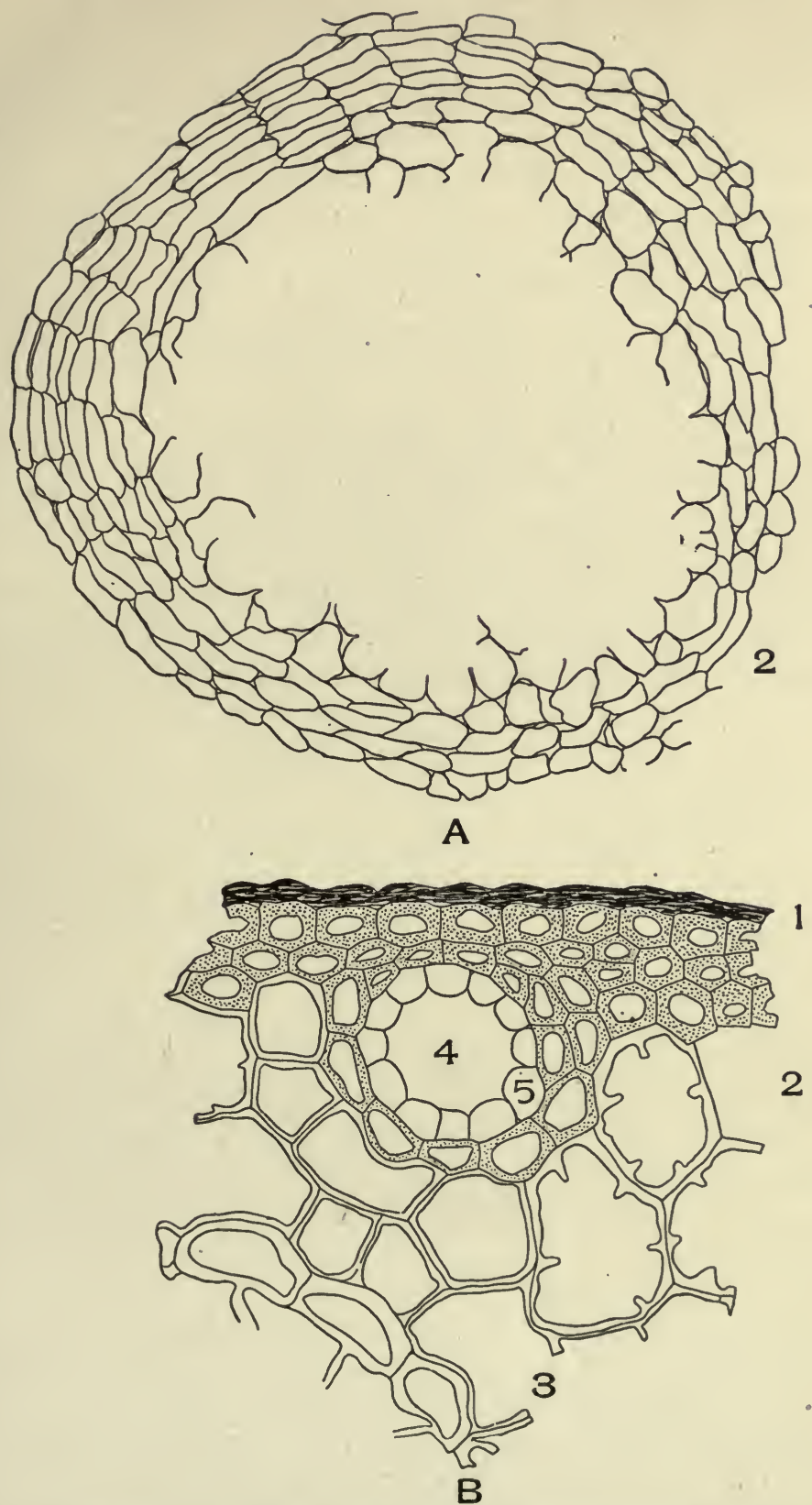

A. Cross-section of bitter orange peel (Citrus aurantium, amara, L.). I, Internal secretion cavity formed by the dissolution of the walls of the central secreting cells; 2 , Secretion cells. B. Cross-section of white pine leaf (Pinus strobus, L.). I, Epidermal and hypodermal cells; 2, Parenchyma cells with protuding inner walls; 3 , Endodermis; 4 , Secretion cavitv; 5 , Secretion cells. 
In calamus (Plate 62, Fig. A) the cavity is larger than the surrounding cells; it is rounded in outline, and it contains oleoresin. These cavities are in contact with the ordinary parenchyma cells, from which they are easily distinguished by their larger size and rounded form.

The unicellular oil cavity of canella alba (Plate 63, Fig. A) is rounded or oval in cross-section and is many times larger than the surrounding cells. The wall, which is very thick, is of a yellowish color.

Secretion cavities vary greatly in form, according to the part of the plant in which they are found. In flower petals and leaves they are spherical; in barks they are usually elliptical; in umbelliferous fruits they are elongated and tube-like.

Mucilage cavities are not of common occurrence in medicinal plants. They occur, however, in the stem and root bark of sassafras, the stem bark of slippery elm, the root of althea, etc. 


\section{CHAPTER VIII}

\section{STORAGE TISSUE}

Most drug plants contain storage products because they are collected at a period of the year when thel plant is storing, or has stored, reserve products. These products are stored in a number of characteristic ways and in different types of tissue.

The most important of the different types of storage tissue that occurs in plants are the storage cells, the storage cavities, and the storage walls.

\section{STORAGE CELLS}

Several different types of cells function as storage tissue. These cells, which are given in the order of their importance, are parenchyma, crystal cells, medullary rays, stone cells, wood fibres, bast fibres, and epidermal and hypodermal cells.

\section{CORTICAL PARENCHYMA}

Cortical parenchyma of biennial rhizomes, bulbs, roots, and the parenchyma of the endosperm of seeds store most of the reserve economic food products of the higher plants.

Pith parenchyma of sarsaparilla root (Plate 65, Fig. 4) and the pith parenchyma of the rhizome of memspermun, like the pith parenchyma of most plants, function as storage cells.

\section{WOOD PARENCHYMA}

Wood parenchyma, particularly of the older wood, function as storage tissue. The wood parenchyma of quassia, like the wood parenchyma of most woods, contain stored products. In some cases the wood parenchyma contain starch, in others crystals, and in others coloring matter, etc.

In many plants, however, the parenchyma cells contain crystals. The parenchyma cells of rhubarb contain rosette 
PLATE 65
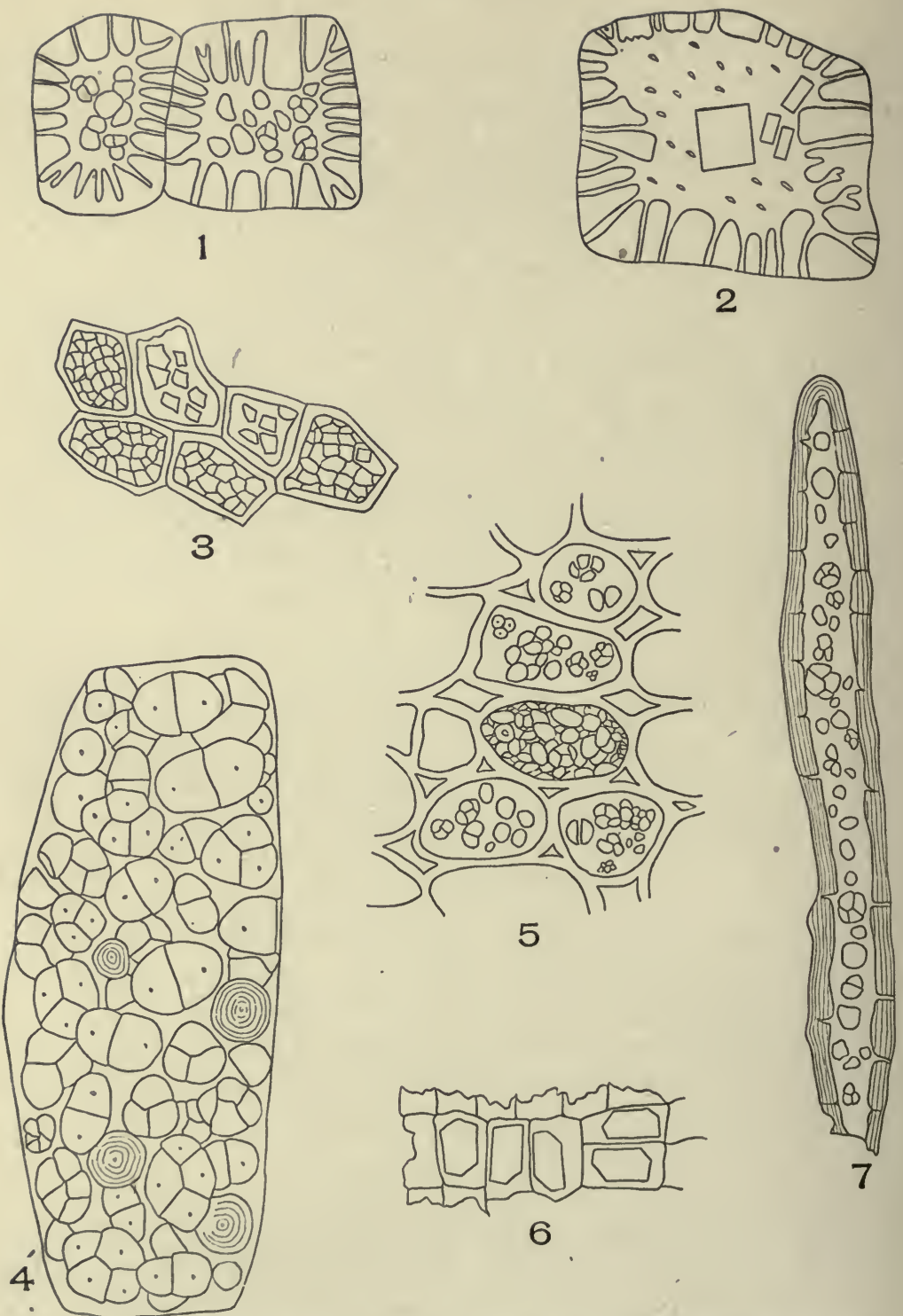

I. Stone cells with starch of Ceylon cinnamon (Cinnamomum seylanicum, Nees.). 2. Stone cells with solitary crystals of calumba root (Jateorhiza palmata, [Lam.] Miers). 3. Parenchyma cells, with starch of cascarilla bark (Croton eluteria, [L.] Benn.). 4. Cortical parenchyma with starch of sarsaparilla root (Smilax officinalis, Kunth). 5. Cortical parenchyma, with starch of leptandra rhizome (Leptandra virginica, [L.] Nutt.). 6. Crystal cells, with solitary crystals of quebracho bark (Schlechtendal). 7. Bast fibre of blackberry root with starch (Rubus cuneifolius, Pursh.). 
PLATE 66

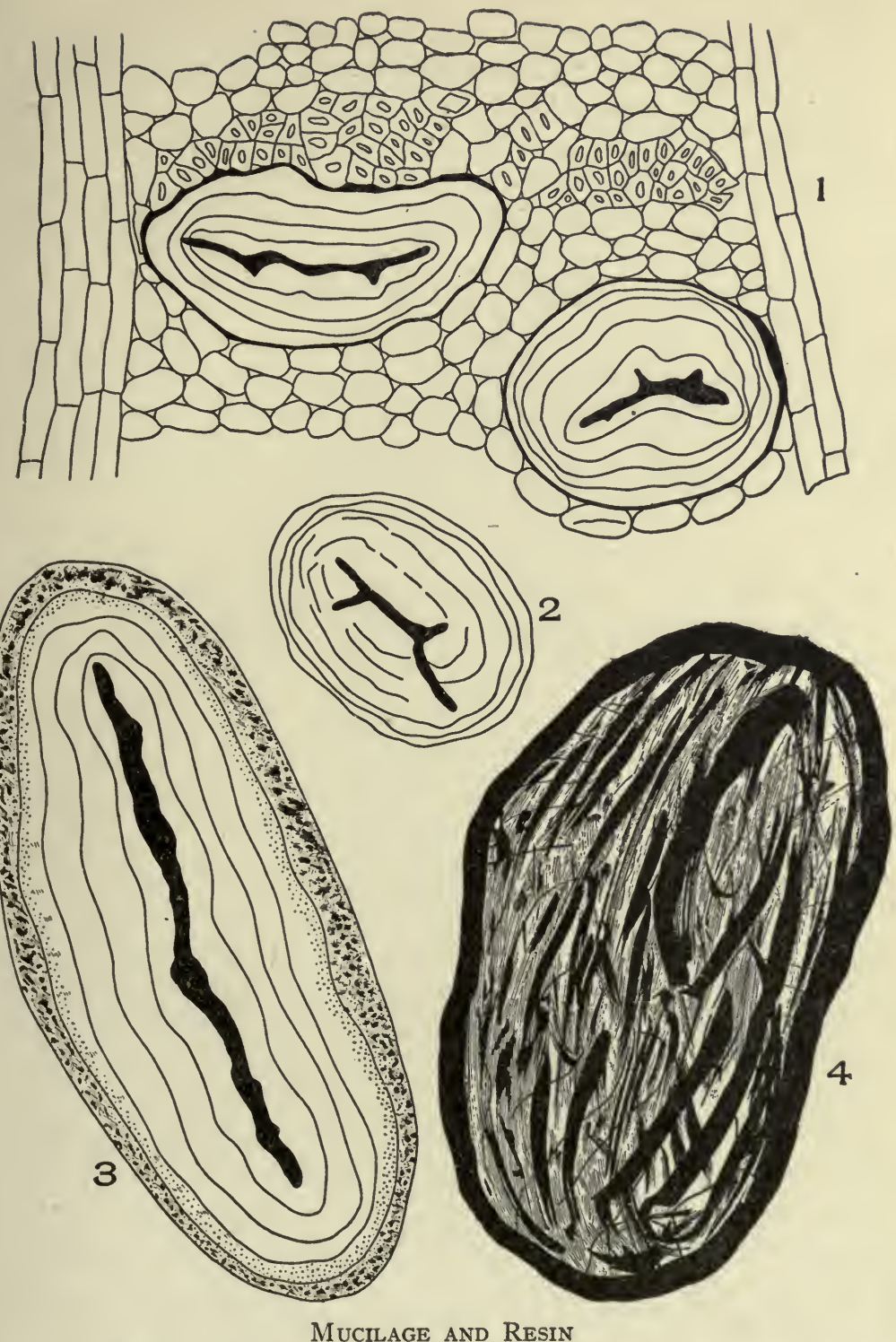

I. Cross-section of elm bark (Ulmus fulva, Michaux) showing two cavities filled with partially swollen mucilage.

2. Mucilage mass from sassafras stem bark (Sassafras variifolium, L.).

3. Mucilage mass from elm bark.

4. Resin mass from white pine bark (Pinus strobus, L.). 
crystals, while the parenchyma cells of the cortex of sarsaparilla and false unicorn root contain bundles of raphides. In every case observed the raphides are surrounded by mucilage. This is true of squills, sarsaparilla, false unicorn, etc. When cells with raphides and mucilage are mounted in a mixture of alcohol, glycerine, and water, the mucilage first swells and finally disappears.

\section{STORAGE CAVITIES}

Particular attention should be given to storage cavities whenever they occur in plants, for the reason that they are usually filled with storage products, and for the added reason that storage cavities are not common to all plants. Storage cavities occur in roots, stems, leaves, flowers, fruits, and seeds.

\section{CRYSTAL CAVITIES}

Characteristic crystal cavities occur in many plants. Such a cavity containing a bundle of raphides is shown in the crosssection of skunk cabbage leaf (Plate 67).

\section{SECRETION CAVITIES}

In white pine bark there are a great number of secretion cavities which are partially or completely filled with oleoresin. In the cross-sections of white pine bark the secretion cavities are very conspicuous, and they vary greatly in size. This variation is due, first, to the age of the cavity, the more recently formed cavities being smaller; and secondly, to the nature of the section, which will be longer in longitudinal section, which will be through the length of the secretion cavity, and shorter on transverse section. Such a section shows the width of the secretion cavity.

Characteristic mucilage cavities occur in sassafras root, stem bark, elm bark (Plate 66, Fig. I), marshmallow root, etc. These cavities form a conspicuous feature of the cross-section of these plants. The presence or absence of mucilage cavities in a bark should be carefully noted.

\section{LATEX CAVITIES}

The latex tube cavities are characteristic in the plants in which they occur. These cavities as explained under latex tubes are very irregular in outline. 
PLATE 67

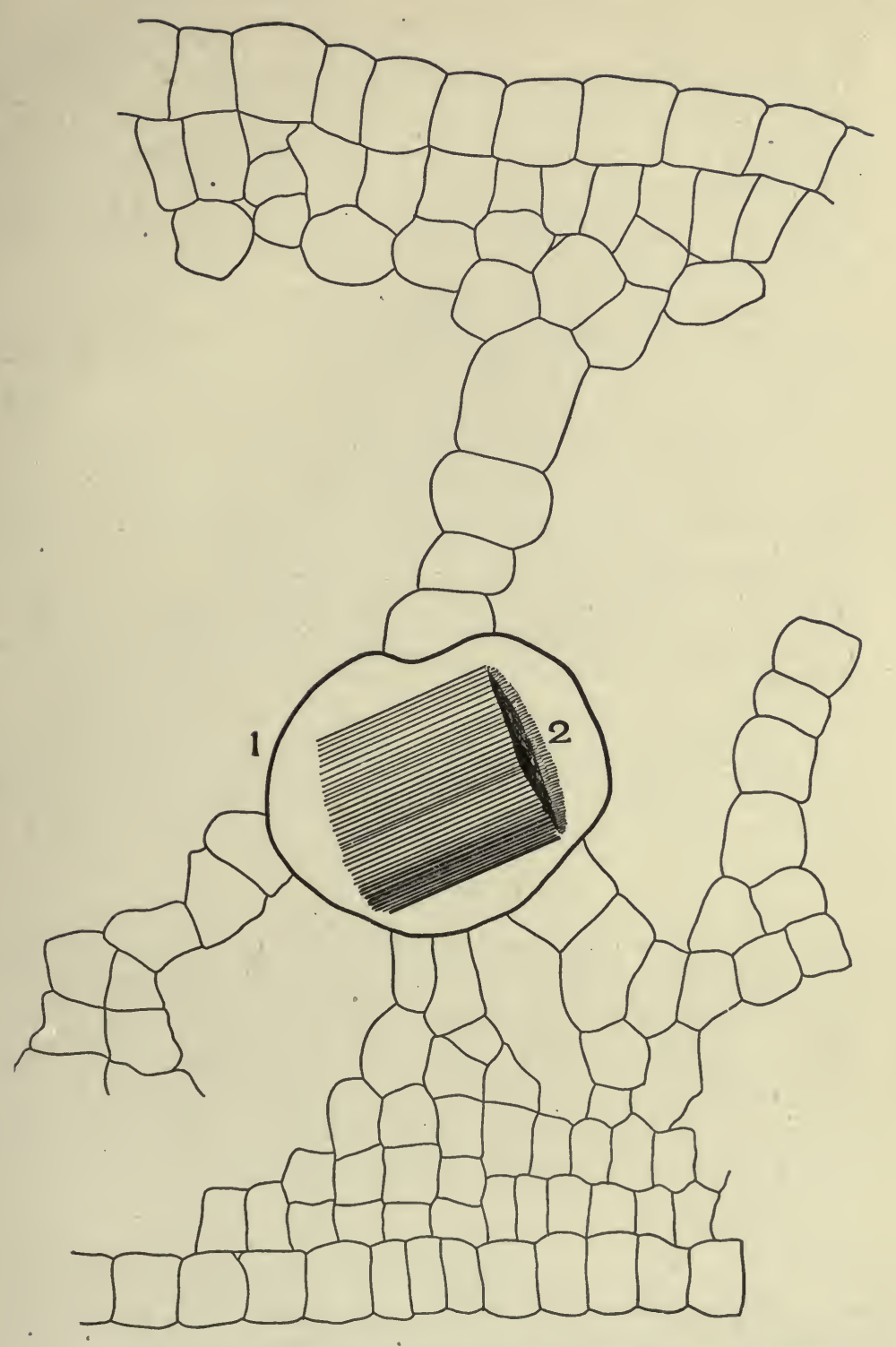

Cross-Section of Skunk-Cabbage Leaf (Symplocarpus fotidus, [L.] Nutt.)

I. Crystal cavity.

2. Bundle of raphides. 


\section{OIL CAVITY}

Canella alba contains an oil cavity resembling in form the mucilage cavity of elm bark.

Secretion cavities occur in most of the umbelliferous fruits. For each fruit there is a more or less constant number of cavities. Anise has twenty or more, fennel usualiy has six cavities, and parsley has six cavities.

In poison hemlock fruits there are no secretion cavities. In certain cases, however, the number of secretion cavities can be made to vary. This was proved by the author in the case of celery seed. He found that cultivated celery seed, from which stalks are grown, contains six oil cavities (Plate 122, Fig. 2), while wild celery seed (Plate 102, Fig. I), grown for its medicinal value, always contains more than six cavities. Most of the wild celery seeds contain twelve cavities.

Many leaves contain cavities for storing secreted products. Such storage cavities occur in fragrant goldenrod, buchu, thyme, savary, etc.

The leaves in which such cavities occur are designated as pellucid-punctate leaves. Such leaves will, when held between the eye and the source of light, exhibit numerous rounded translucent spots, or storage cavities.

\section{GLANDULAR HAIRS}

The glandular hair of peppermint (Plate 6o, Fig. 3) and other mints consists of eight secretion cells, arranged around a central cavity and an outer wall which is free from the secretion cells. This outer wall becomes greatly distended when the secretion cells are active, and the space between the secretion cells and the wall serves as the storage place for the oil. When the mints are collected and dried, the oil remains in the storage cavity for a long time.

\section{STONE CELLS}

The stone cells of the different cinnamons (Plate 65, Fig. I) store starch grains; these grains often completely fill the stone cells.

The yellow stone cells of calumba root (Plate 65, Fig. 2) usually contain four prisms of calcium oxalate, which may be nearly uniform or very unequal in size. 


\section{BAST FIBRES}

The bast fibres of the different rubus species (Plate $6_{5}$, Fig. 7) contain starch. The medullary rays of quassia (Plate I07, Fig. 2) contain starch; while the medullary rays of canella alba contain rosette crystals. In a cross-section of canella alba (Plate 8I, Fig. 3) the crystals form parallel radiating lines which, upon closer examination, are seen to be medullary rays, in each cell of which a crystal usually occurs."

The epidermal and hypodermal cells of leaves serve as water-storage tissue. These cells usually appear empty in a section.

The barks of many plants-i.e., quebracho, witch-hazel, cascara, frangula, the leaves of senna and coca, and the root of licorice - contain numerous crystals. These crystals occur in special storage cells-crystal cells (Plate 65, Fig. 6)-which usually form a completely enveloping layer around the bast fibres. These cells are usually the smallest cells of the plant in which they occur, and with but few exceptions each cell contains but a single crystal.

The epidermal cells of senna leaves and the epidermal cells of mustard are filled with mucilage; the walls even consist of mucilage. Such cells are always diagnostic in powders.

\section{STORAGE WALIS}

Storage walls (Plates 68 and 69) occur in colchicum seed, saw palmetto seed, areca nut, nux vomica, and Saint Ignatius's bean. In each of these seeds the walls are strongly and characteristically thickened and pitted. In no two plants are they alike, and in each plant they are important diagnostic characters.

Storage cell walls consist of reserve cellulose, a form of cellulose which is rendered soluble by ferments, and utilized as food during the growth of the seed. Reserve cellulose is hard, bony, and of a waxy lustre when dry. Upon boiling in water the walls swell and become soft.

The structure of the reserve cellulose varies greatly in the different seeds in which it occurs in the thickness of the walls and in the number and haracter of the pores. 

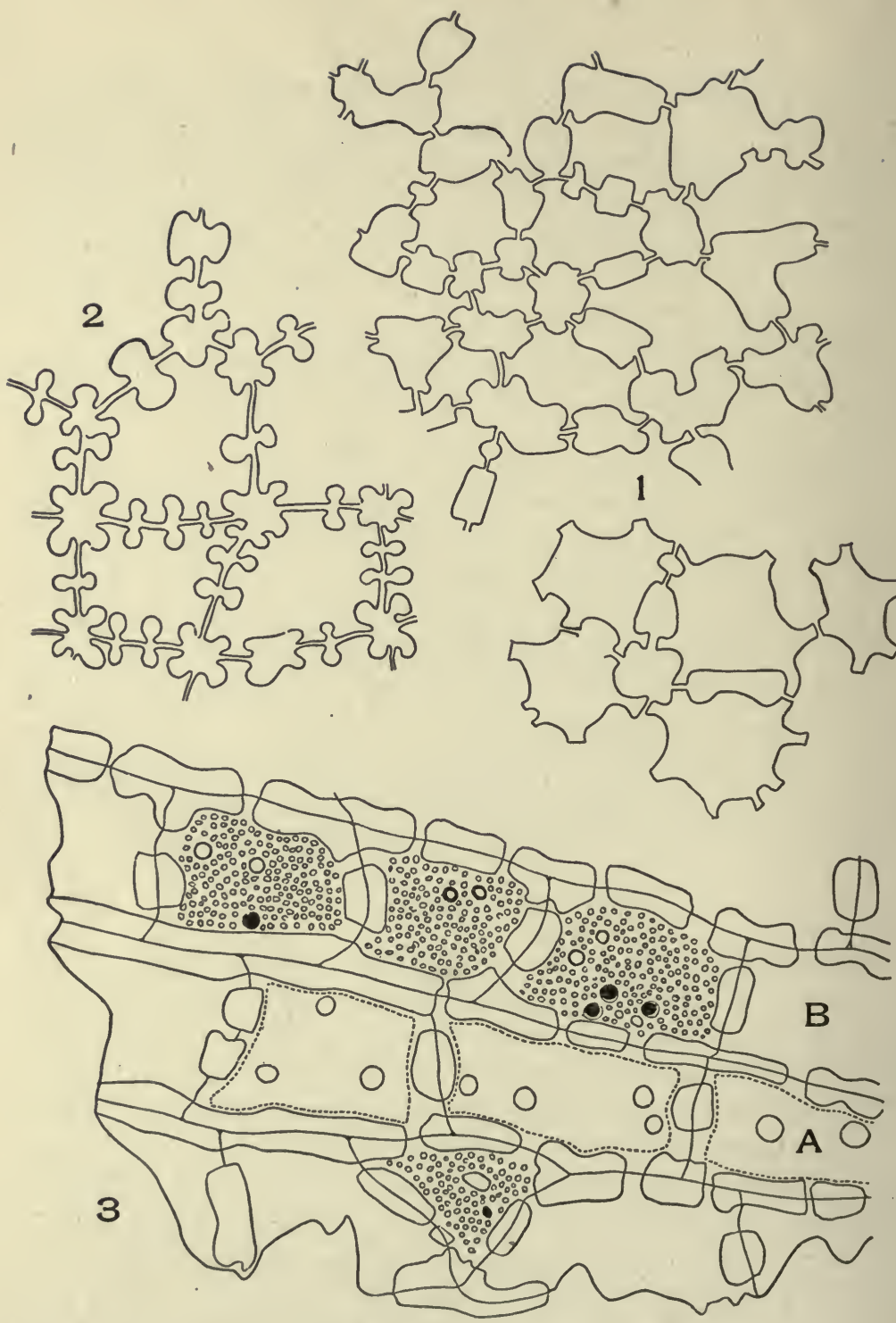

\section{Reserve Cellulose}

I. Saw palmetto (Serenoa serrulata, [Michaux] Hook., f.).

2. Areca nut (Areca catechu, L.).

3. Colchicum seed (Colchicum autumnale, L.). 3- $A$. Porous side wall.

$3-B$. Cell cavity above the side wall. 
PLATE 69

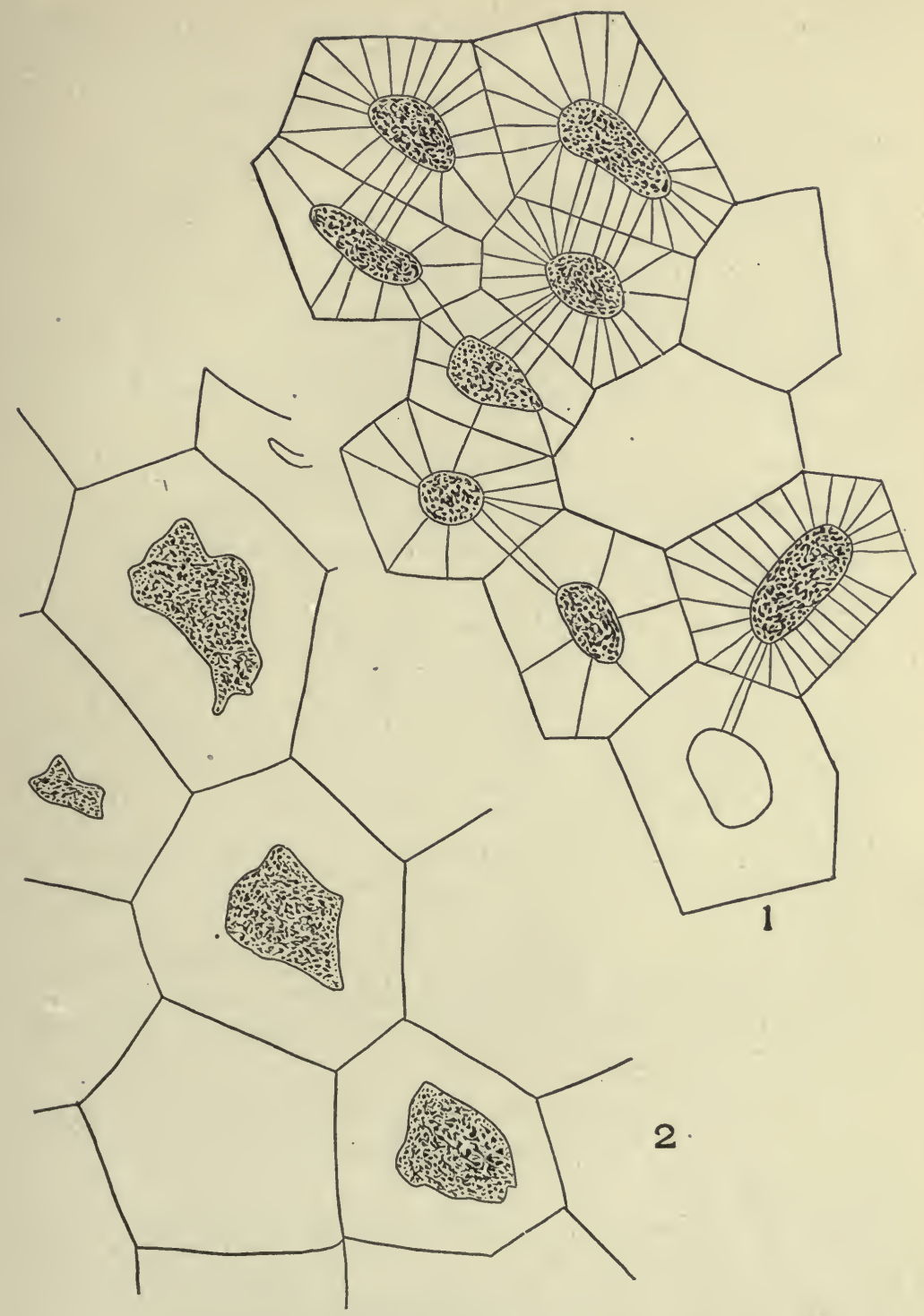

\section{Reserve Cellulose}

I. Endosperm of nux vomica (Strychnos nux vomica, L.).

2. Endosperm of St. Ignatia bean (Strychnos ignatii, Berg.). 


\section{CHAPTER IX}

\section{CELL CONTENTS}

The cell contents of the plant are divided into two groups: first, organic cell contents; and secondly, inorganic cell contents.

The organic cell contents include plastids, starch grains, mucilage, inulin, sugar, hesperidin, alkaloids, glucocides, tannin, resin, and oils.

\section{CHLOROPHYLL}

The chloroplasts of the higher plants are green, and they vary somewhat in size, but they have a similar structure and form.

Chlorøplasts are mostly oval in longitudinal view and rounded in cross-section view. Each chlorophyll grain has an extremely thin outer wall, which encloses the protoplasmic substance, the green granules, a green pigment (chlorophyll), and a yellow pigment (xanthophyll). Frequently the wall includes starch, oil drops, and protein crystals.

Chloroplasts are arranged either in a regular peripheral manner along the walls, or they are diffused throughout the protoplast.

The palisade cells of most leaves are packed with chlorophyll grains. In the mesophyll cells the chlorophyll grains are not so numerous, and they are arranged peripherally around the innermost part of the wall.

Chloroplasts multiply by fission-that is, each chloroplast divides into two equal halves, each of which develops into a normal' chloroplast.

Chlorophyll occurs in the palisade, spongy parenchyma, and guard cells of the leaf; in the collenchyma and parenchyma of the cortex of the stems of herbs and of young woody stems, and, under, certain conditions, in rhizomes and roots exposed to light. Almost without exception young seeds and fruits have chlorophyll. 
In powdered leaves, stems, etc., the chlorophyll grains occur in the cells as greenish, more or less structureless masses. Yet cells with chlorophyll are readily distinguished from cells with other cell contents. In witch-hazel leaf the chlorophyll grains appear brownish in color. Powdered leaves and herbs are readily distinguished from bark, wood, root, and flower powders.

Leaves and the stems of herbs are of a bright-green color. With the exception of the guard cells, the chloroplasts occur one or more layers below the epidermis; but, owing to the translucent nature of the outer walls of these cells, the outer cells of leaves and stems appear green.

Wild cherry, sweet birch, and, in fact, most trees witn smooth barks have chloroplasts in several of the outer layers of the cortical parenchyma. When the thin outer bark is removed from these plants, the underlying layers are seen to be of a bright-green color.

\section{LEUCOPLASTIDS}

Leucoplastids, or colorless plastids, occur in the underground portions of the plant; they may, when these organs in which they occur are exposed to light, change to chloroplastids.

Leucoplasts are the builders of starch grains. They take the chemical substance starch and build or mould it into starch grains, storage starch, or reserve starch.

Other characteristic chromoplasts found in plants are yellow and red. Yellow chromoplasts occur in carrot root and nasturtium flower petals. Red plastids occur in the ripe fruit of capsicum.

\section{STARCH GRAINS}

The chemical substance starch $\left(\mathrm{C}_{6} \mathrm{H}_{10} \mathrm{O}_{5}\right)$ is formed in chloroplasts. The starch thus formed is removed from the chloroplasts to other parts of the plant because it is the function of the chloroplasts to manufacture and not to store starch.

The starch formed by the chloroplasts is acted upon by a ferment which adds one molecule of water to $\mathrm{C}_{6} \mathrm{H}_{10} \mathrm{O}_{5}$, thus forming sugar $\mathrm{C}_{6} \mathrm{H}_{12} \mathrm{O}_{6}$. This sugar is readily soluble in the 
cell sap, and is conducted to all parts of the plant. The sugar not utilized in cell metabolism is stored away in the form of reserve starch or starch grains by colorless plastids or amyloplasts.

The amyloplasts change the sugar into starch by extracting a molecule of water. This structureless material (starch) is then formed by the amyloplast into starch grains having a definite and characteristic form and structure:

Starch grains vary greatly in different species of plants, owing probably to the variation of the chemical composition, density, etc., of the protoplast, and to the environmental conditions under which the plant is growing.

\section{OCCURRENCE}

Starch grains are simple, compound, or aggregate. Simple starch grains may occur as isolated grains (Plates 70, $7 \mathrm{I}$, and 72 ), or they may be associated as in cardamon seed, white pepper, cubeb, and grains of paradise, where the simple grains stick together in masses, having the outline of the cells in which they occur. These masses are known as aggregate starch.

Aggregate starch (Plate 76) varies greatly in size, form, and in the nature of the starch grains forming the aggregations.

Compound starch grains may be composed of two or more parts, and they are designated as 2, 3, 4, 5, etc., compound (Plate 75).

The parts of a compound grain may be of equal size (Plate 75, Fig. 4), or they may be of unequal size (Plate 75, Fig. 2).

In most powders large numbers of the parts of the compound grains become separated. The part in contact with other grains shows plane surfaces, while the external part of the grain has a curved surface. There will be one plane and one curved surface if the grain is a half of a two-compound grain; two plane and one curved surface if the grain is a part of a threecompound grain, etc.

The simple starch grains forming the aggregations become separated during the milling process and occur singly, so that in the drugs cited above the starch grains are solitary and aggregate.

Many plants contain both simple and compound starch grains (Plate 74, Fig. 3). 
In some forms-e.g., belladonna root (Plate 75 , Fig. 2) the compound grains are more numerous; while in sanguinaria the simple grains are more numerous, etc.

\section{OUTLINE}

The outline of starch grains is made up of (I) rounded, (2) angled, and (3) rounded and angled surfaces.

Starch grains with rounded surfaces may be either spherical, as in Plate 74 , Fig. 3, or oblong or elongated, as in Plate $7 \mathrm{I}$, Fig. I.

Other starches with rounded surfaces are shown on Plates 72 and 73 .

Angled outlined grains are common to cardamon seed, white pepper, cubebs, grains of paradise (Plate 76 , Fig. 4 ), and to corn (Plate 70, Fig. 3).

The outlines of all compound grains are made up partly of plane and partly of curved surfaces.

\section{SIZE}

The size (greatest diameter) of starch varies greatly even in the same species, but for each plant there is a normal variation.

In spherical starch grains the size of the individual grains is invariable, but in elongated starch grains and in parts of compound grains the size will vary according to the part of the grain measured. In zedoary starch (Plate 7I, Fig. 4), for instance, the size will vary according to whether the end, side, or surface of the starch grain is in focus.

The parts of compound grains often vary greatly in size. Such a variation is shown in Plate 75, Fig. 2.

\section{HILUM}

The hilum is the starting-point of the starch grain or the first part of the grain laid down by the amyloplast. The hilum will be central if formed in the middle of the amyloplast, and excentral if formed near the surface of the amyloplast. It has been shown that the developing starch grain with eccentric hilum usually extends the wall of the amyloplast if it does not actually break through the wall. Starch grains with excentral hilums are therefore longer than broad. 

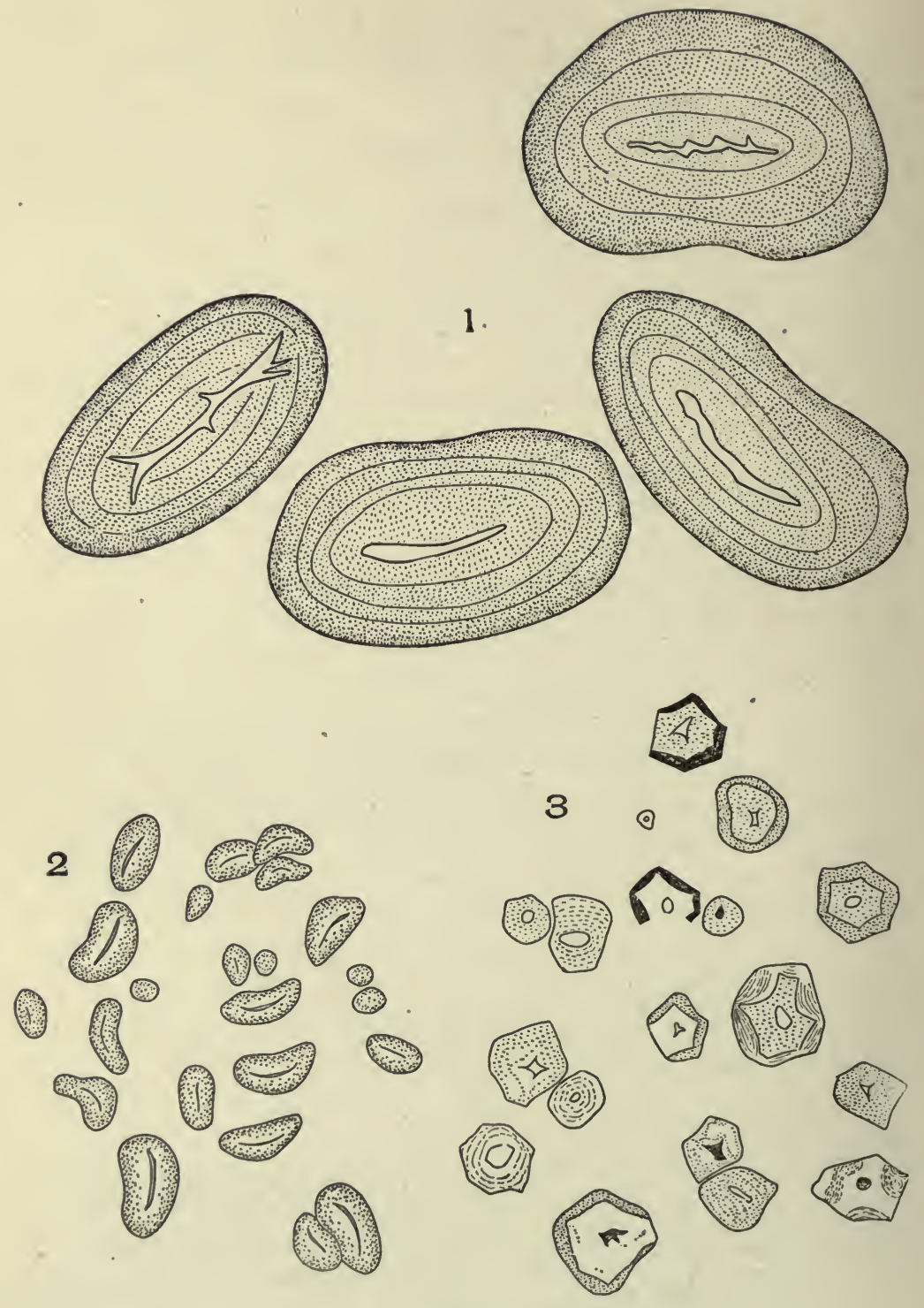

STARCH

I. Calabar bean (Physostigma venenosum, Balfour).

2. Marshmallow root (Althoa officinalis, L.).

3. Field corn (Zea mays, L.). 


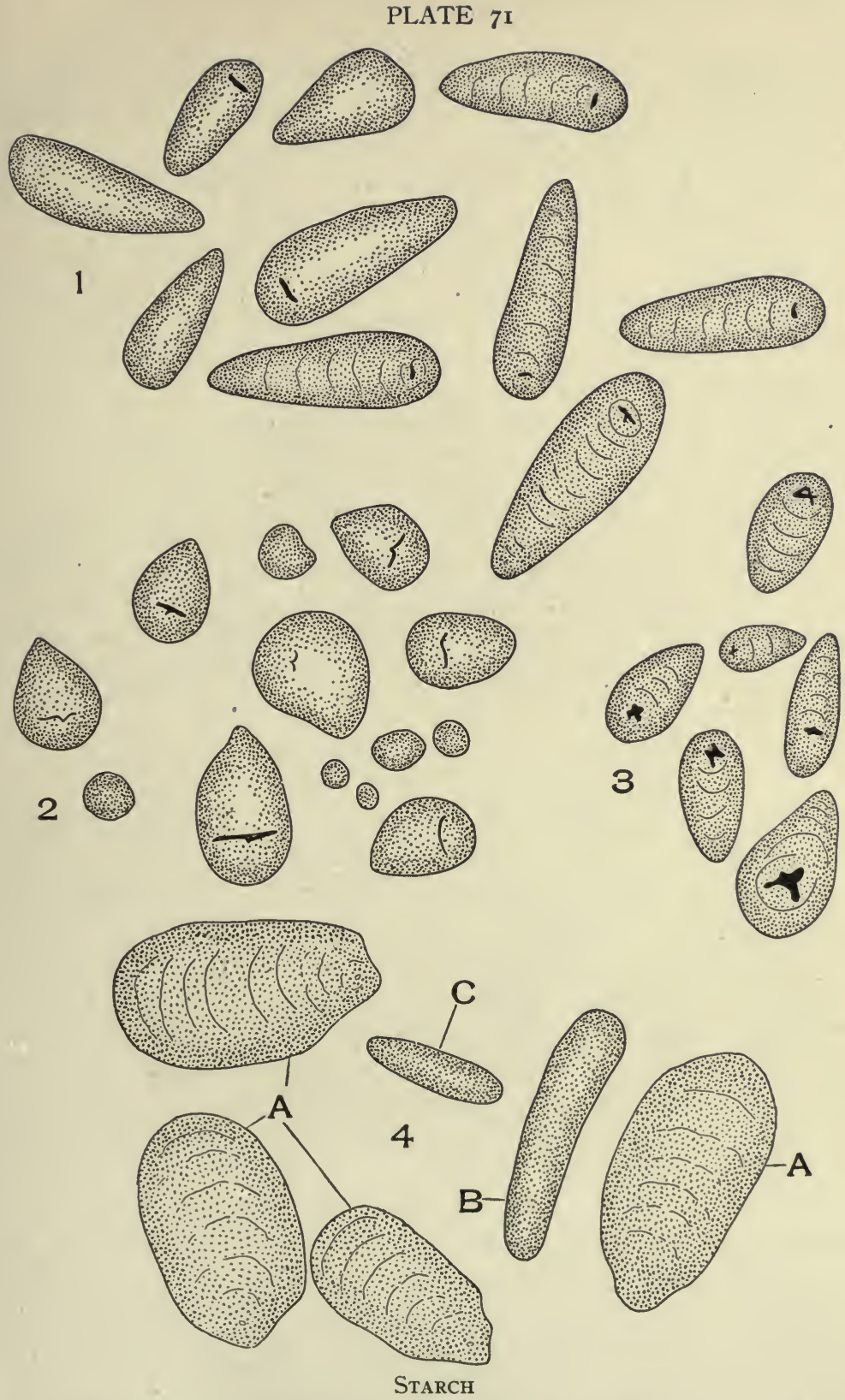

I. Galanga root (Alpinia officinarum, Hance). 2. Kola nut (Cola vera, [K.] Schum.). 3. Geranium rhizome (Geranium maculatum, L.). 4. Zedoary root (Curcuma zedoaria, Rosc.). 4-A. Surface view of starch grain. 4-B. Side view of starch grain. 4 -C. End view of starch grain. 
In central hilum starch grains the grain is laid down around the hilum in the form of concentric layers. These layers are of variable density. The dense layers are formed when plenty of sugar is available, and the less dense layers are formed when little sugar is available. The unequal density of the different layers gives the striated appearance characteristic of so many starch grains.

In eccentric hilum starch grains the starch will be deposited in layers which are outside of and successively farther from the hilum.

The term hilum has come to have a broader meaning than formerly. Hilum includes at the present time not only the starting-point of the starch grain, but the fissures which form in the grain upon drying. In all cases these fissures originate in the starting-point, hilum, and in some cases extend for some distance from it. The hilum, when excentral, may occur in the broad end of the grain, galanga, and geranium (Plate $7 \mathrm{I}$, Figs. I and 3), or in the narrow end of the grain, zedoary (Plate 7 I, Fig. 4).

\section{NATURE OF THE HILUM}

The hilum, whether central or excentral, may be rounded (Plate 75, Fig. I); or simple cleft, which may be straight (Plate 7I, Fig. I); or curved cleft (Plate 7I, Fig. 2); or the hilum may be a multiple cleft (Plate 74, Fig. 3).

In studying starches use cold water as the mounting medium, because in cold water the form and structure are best shown, and because there is no chemical action on the starch. On the other hand, the form and structure will vary considerably if the starch is mounted in hot water or in solutions of alkalies or acids. The hilum appears colorless when in sharp focus, and black when out of focus.

Starch grains, when boiled with water, swell up and finally disintegrate to form starch paste.

Starch paste turns blue upon the addition of a few drops of weak lugol solution. Upon heating, this blue solution is decolorized, but the color reappears upon cooling. If a strong solution of lugol is used in testing, the color will be bluish black. 
PLATE 72

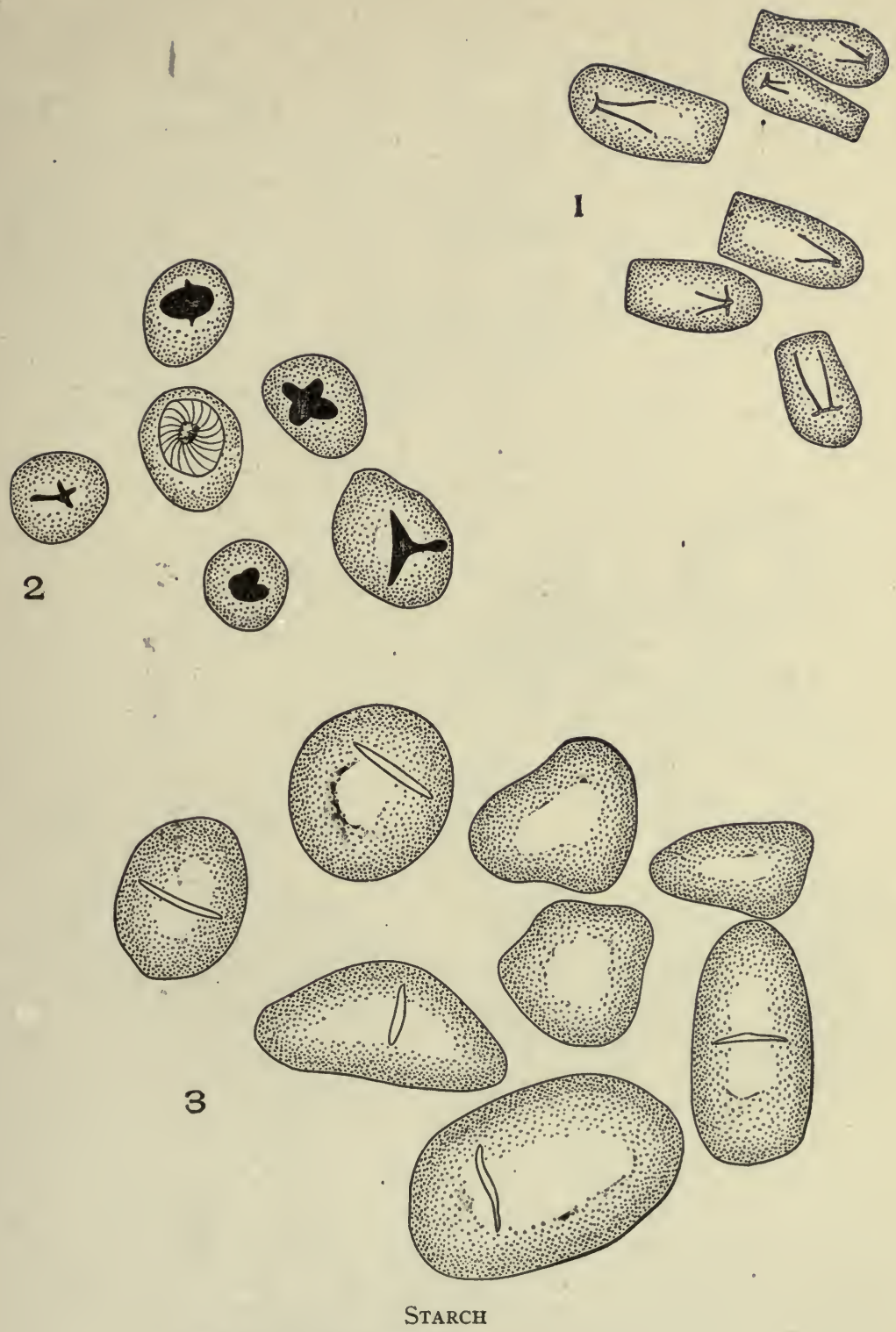

I. Orris root (Iris florentinia L.).

2. Stillingea root (Stillingea sylvatica, L.).

3. Calumba root (Jateorhiza palmata, [Lam.] Miers.). 

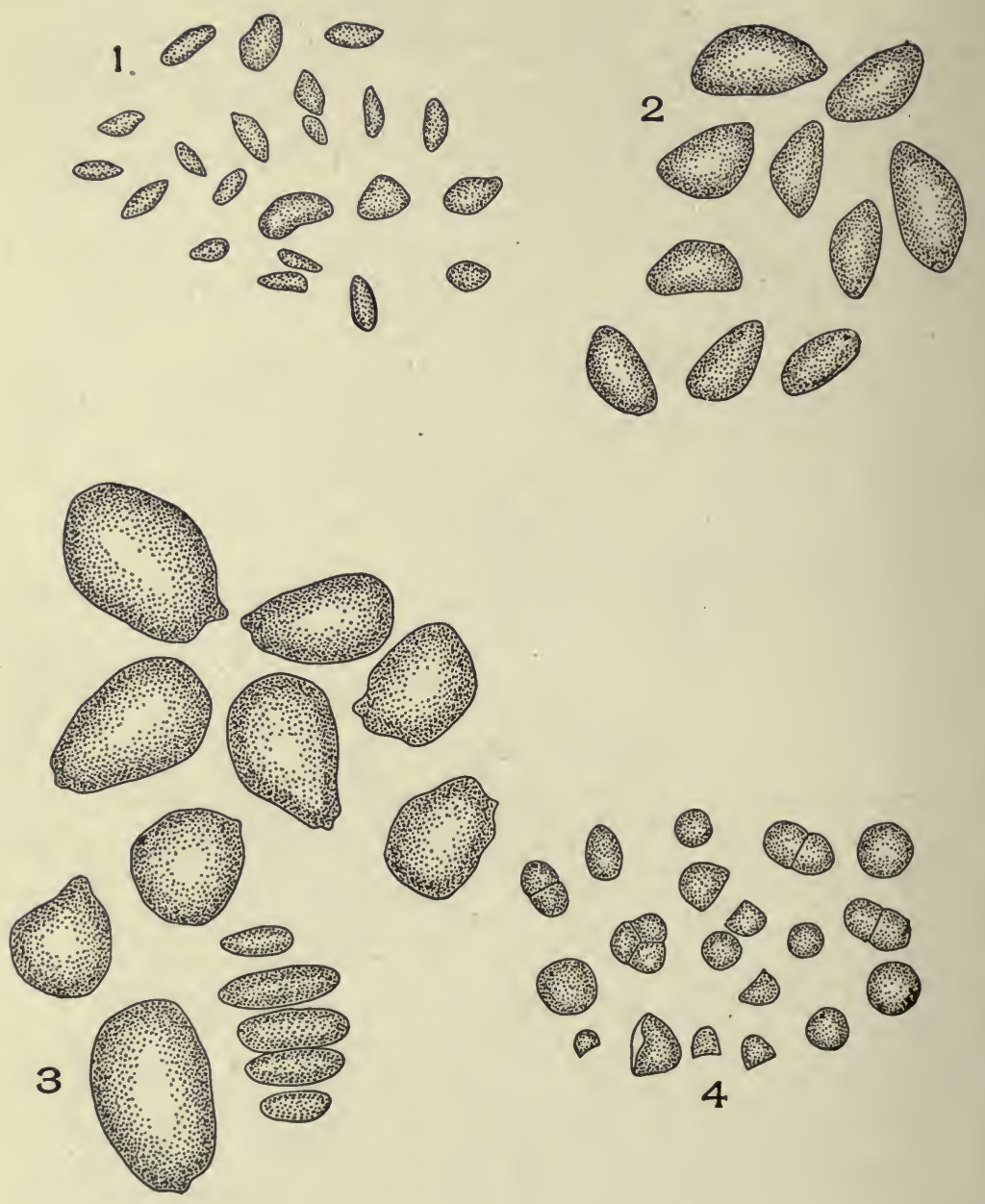

STARCH

I. Male fern (Dryopteris marginalis, [L.] A. Gray).

2. African ginger (Zingiber officinalis, Rosc.).

3. Yellow dock (Rumex crispus, L.).

4. Pleurisy root (Asclepias tuberosa, L.). 
PLATE 74
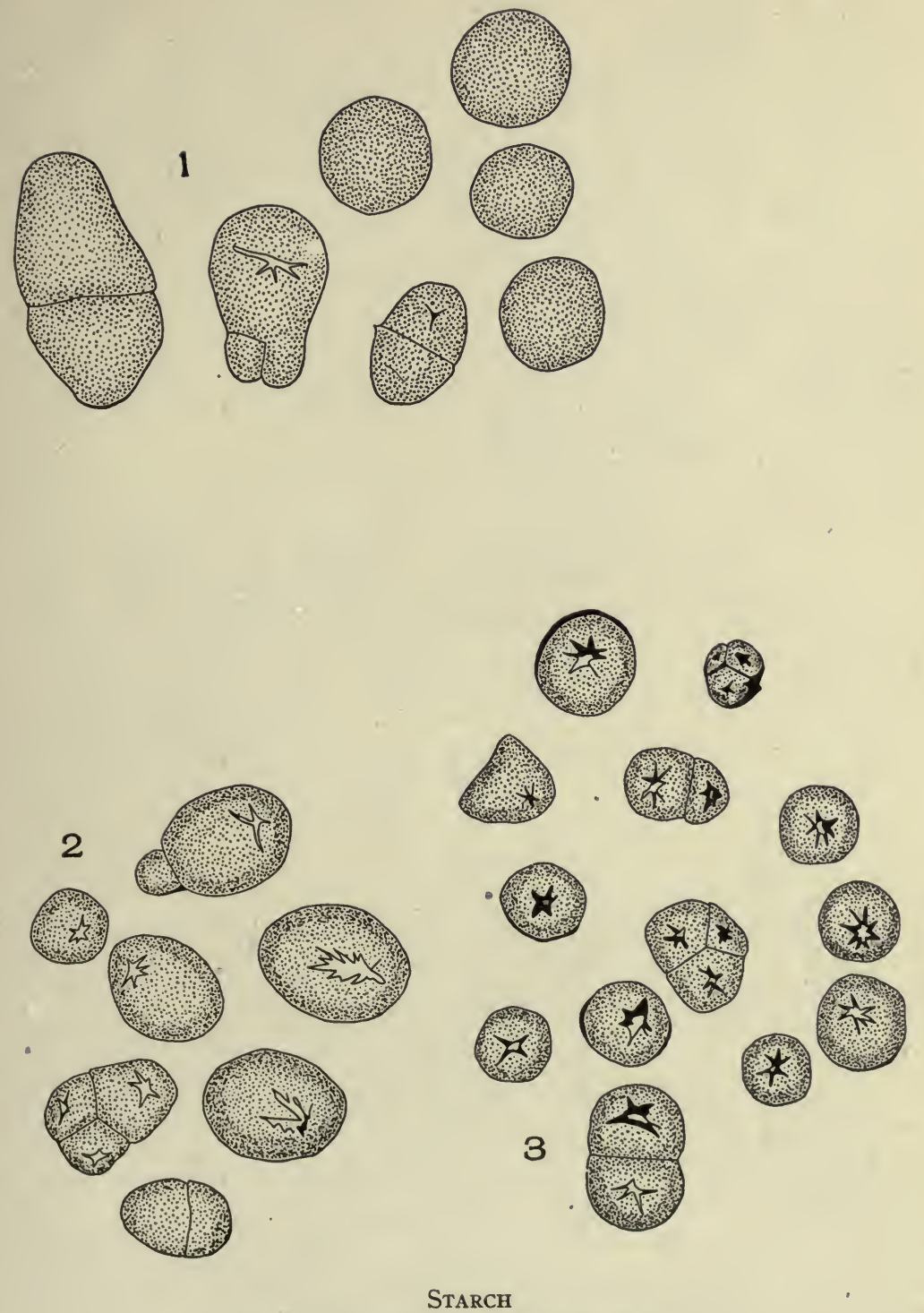

I. Kava-kava (Piper methysticum, Forst., f.).

2. Pokeroot (Phytolacca americana, L.).

3. Rhubarb (Rheum officinale, Baill.). 


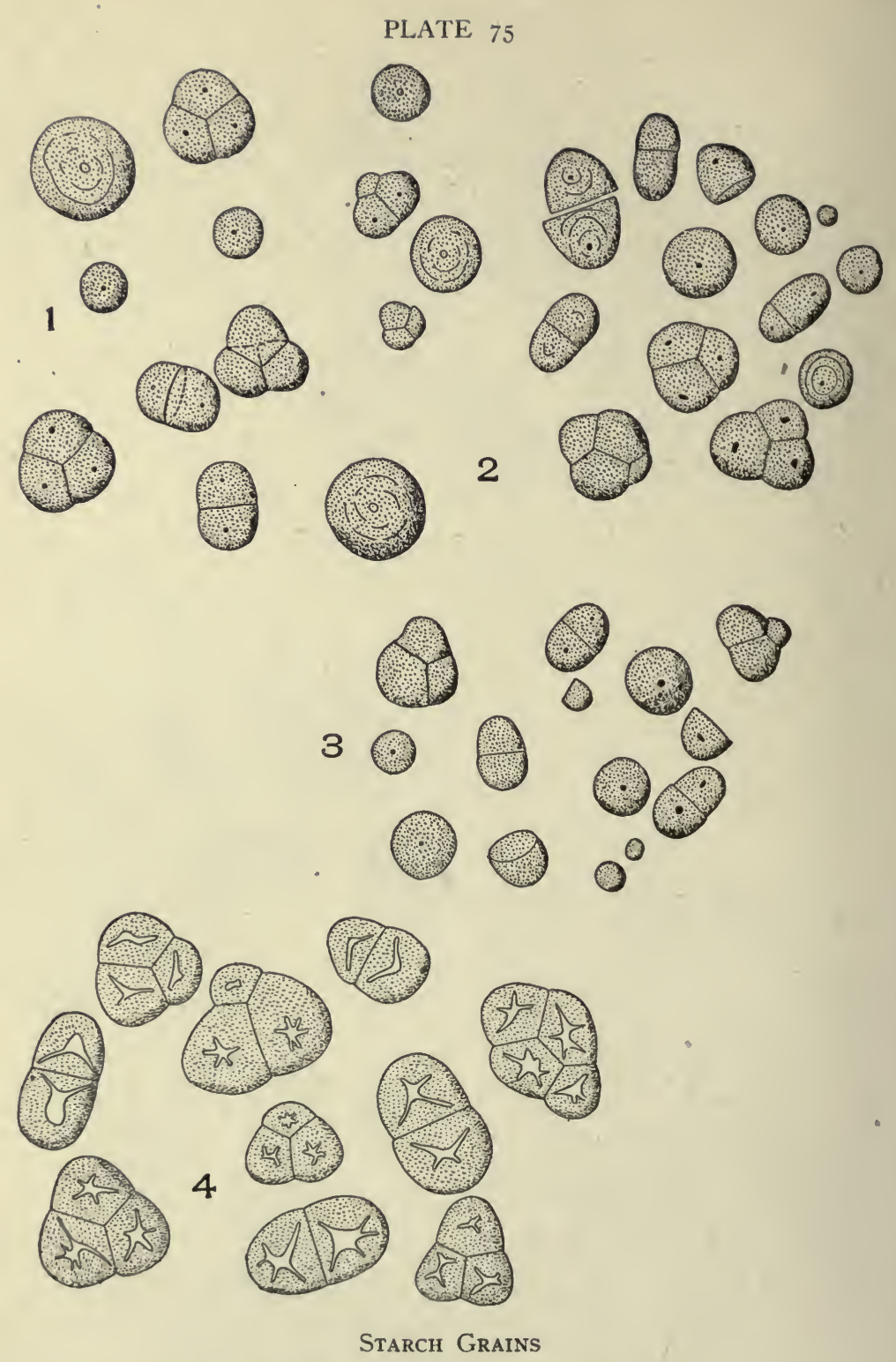

I. Bryonia (Bryonia alba, L.).

2. Belladonna root (Atropa belladonna, L.).

3. Valerian root (Valeriana officinalis, L.).

4. Colchicum root (Colchicum autumnale, L.). 
PLATE 76

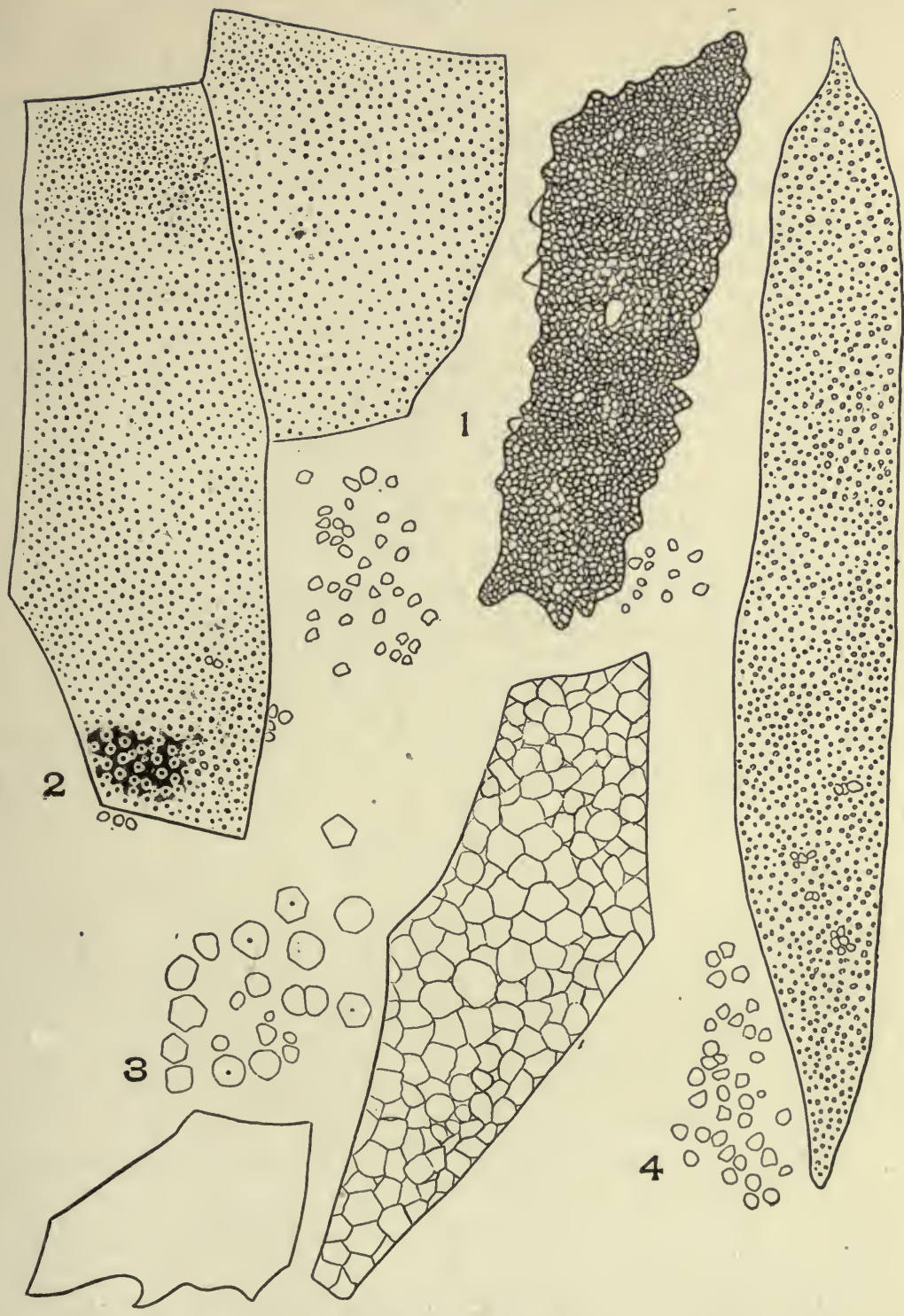

STARCH MASSES

I. Aggregate starch of cardamon seed (Elettaria cardamomum, Maton).

2. Aggregate starch of white. pepper (Piper nigrum, L.).

3. Aggregate starch of cubebs (Piper cubeba, L.; f.).

4. Aggregate starch of grains of paradise (Amomum meleguetta, Rosc.). 


\section{INULIN}

Inulin is the reserve carbohydrate material found in the plants of the composite family.

The medicinal plants containing inulin are dandelion, chicory, elecampane, pyrethrum, and burdock. Plate 77, Figs. I and 2 show masses of inulin in dandelion and pyrethrum.

In these plants the inulin occurs in the form of irregular, structureless, grayish-white masses (Plate 77). In powdered drugs inulin occurs either in the parenchyma cell or as irregular isolated fragments of variable size and form. Inulin is structureless and the inulin from one plant cannot be distinguished microscopically from the inulin of another plant. For this reason inulin has little or no diagnostic value. The presence . or absence of inulin should always be noted, however, in examining powdered drugs, because only a few drugs contain inulin.

When cold water is added to a powder containing inulin it dissolves. Solution will take place more quickly, however, in hot water. Inulin occurs in the living plant in the form of cell sap. If fresh sections of the plant are placed in alcohol or glycerine, the inulin precipitates in the form of crystals.

\section{MUCILAGE}

Mucilage is of common occurrence in medicinal plants. Characteristic mucilage cavities filled with mucilage occur in sassafras stem (Plate 66, Fig. 2), in elm bark (Plate 66, Fig. I), in althea root, in the outer layer of mustard seed, and in the stem. of cactus grandiflorus. In addition, mucilage is found associated with raphides in the crystal cells of sarsaparilla, squill, false unicorn, and polygonatum.

When drugs containing mucilage are added to alcohol, glycerine, and water mixture, the mucilage swells slightly and becomes distinctly striated, but it will not dissolve for a long time. Refer to Plate 79, Fig. 6.

Mucilage, when associated with raphides, swells and rapidly dissolves when added to alcohol, glycerine, and water mixture. The mucilage is, therefore, different from the mucilage found in mucilage cavities, because it is more readily soluble.

In coarse-powdered bark and other mucilage containing 


\section{PLATE 77}
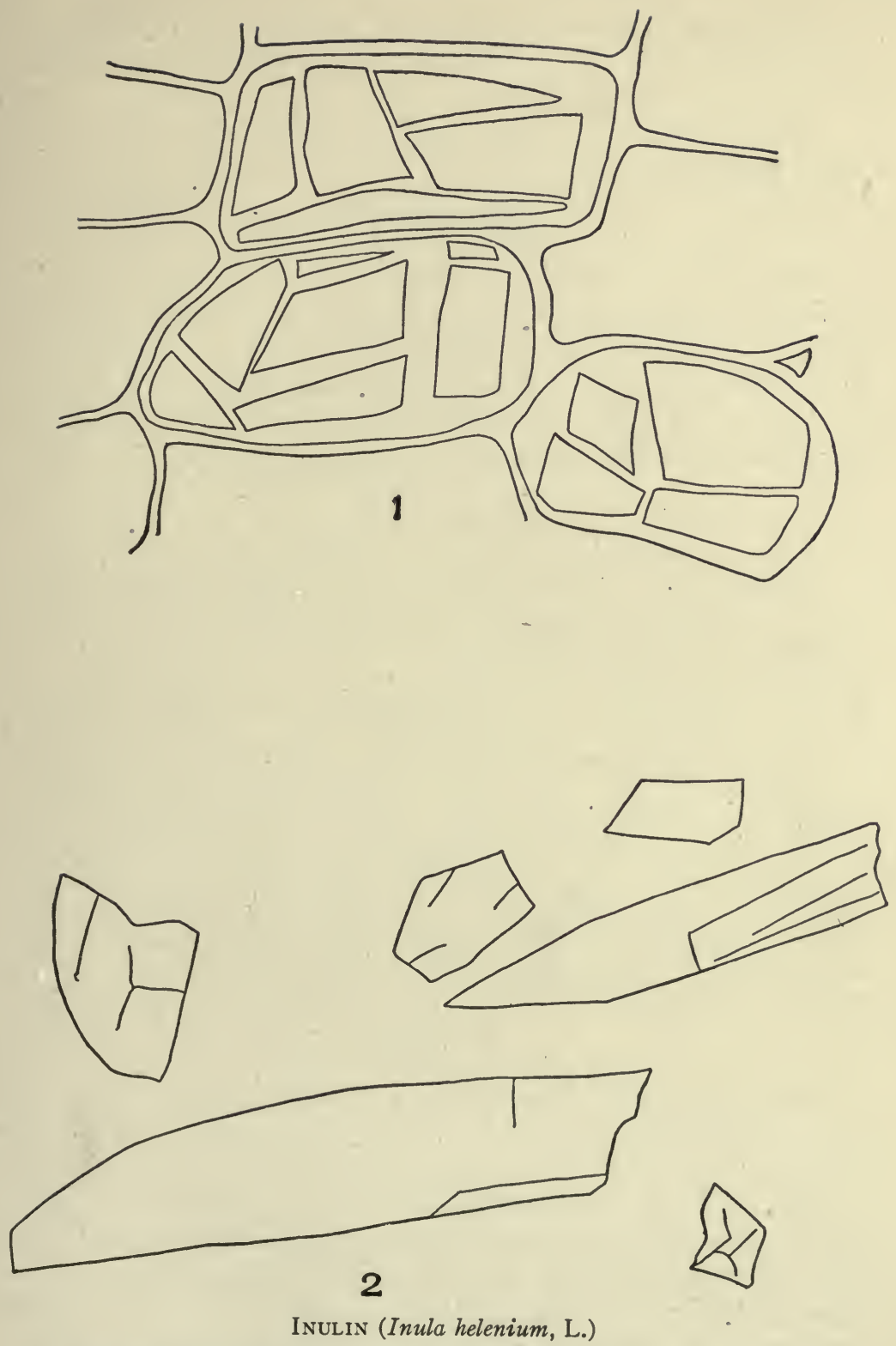

I. Inulin in the parenchyma cells of dandelion root.

2. Inulin from Roman pyrethrum root (Anacyclus pyrethrum, [L.] D. C.). 
drugs the mucilage masses are mostly spherical or oval in outline (Plate 66, Figs. 2 and 3) the form being similar to the cavity in which the mass occurs.

Acacia, tragacanth, and India gum consist of the dried mucilaginous excretions.

\section{HESPERIDIN}

Hesperidin occurs in the epidermal cells of short and long buchu. It is particularly characteristic in the epidermal cells of the dried leaves of short buchu. In these leaves the hesperidin occurs in masses which resemble rosette crystals (Plate 54, Fig. I).

Hesperidin is insoluble in glycerine, alcohol, and water, but it dissolves in alkali hydroxides, forming a yellowish solution.

\section{VOLATILE OILS}

Volatile oils occur in cinnamon stem bark, sassafras root bark, flowers of cloves, and in the fruits of allspice, anise, fennel, caraway, coriander, and cumin.

In none of these cases is the volatile oil diagnostic, but its presence must always be determined.

When a powdered drug containing a volatile oil is placed in alcohol, glycerine, and water mixture the volatile oil contained in the tissues will accumulate at the broken end of the cells in the form of rounded globules, while the volatile oil adhering to the surface of the fragments will dissolve in the mixture and float in the solution near the under side of the cover glass. Volatile oil is of little importance in histological work.

\section{TANNIN}

Tannin masses are usually red or reddish brown. Tannin occurs in cork cells, medullary rays of white pine bark (Plate 48, Fig. B), stone cells, and in special tannin sacs.

The stone cells of hemlock and tamarac bark and the medullary rays of white pine and hemlock bark contain tannin.

Tannin associated with prisms occurs in tannin sacs in white pine and tamarac bark. These sacs are frequently several millimeters in length and contain a great number of crystals surrounded by tannin. 
Deposits of tannin are colored bluish black with a solution of ferric chloride.

\section{ALEURONE GRAINS}

Aleurone grains are small granules of variable structure, size, and form, and they are composed of reserve proteins. They occur in celery, fennel, coriander, and anise, fruits, in sesame, sunflower, curcas, castor oil, croton oil, bitter almond, and other oil seeds.

In many of the seeds the aleurone grains completely fill the cells of the endosperm, embryo, and peristerm. In wheat, rye, barley, oats, and corn the aleurone grains occur only in the outer layer or layers of the endosperm, the remaining layers in these cases being filled with starch.

In powdered drugs the aleurone grains occur in parenchyma cells or free in the field.

\section{STRUCTURE OF ALEURONE GRAINS}

Aleurone grains are very variable in structure. The simplest grains consist of an undifferentiated mass of proteid substance surrounded by a thin outer membrane. In other grains the proteid substance encloses one or more rounded denser proteid bodies known as globoids. In other grains a crystalloid - crystallike proteid substance-is present in addition to the globoid. In some grains are crystals of calcium oxalate, which may occur as prisms or as rosettes. All the different parts, however, do not occur in any one grain. In castor-oil seed (Plate 77a, Fig. 8) are shown the membrane $(A)$, the ground mass $(B)$, the crystalloid $(C)$, and the globoid $(D)$.

\section{FORM OF ALEURONE GRAINS}

Much attention has been given to the study of the special parts of the aleurone grains, but one of the most important diagnostic characters has been overlooked, namely, that of comparative form. For the purposes of comparing the forms of different grains, they should be mounted in a medium in which the grain and its various parts are insoluble. Oil of "cedar is such a medium. The variation in form and size of the aleurone grains when mounted in oil of cedar is shown in Plate $77 a$. 


\section{DESCRIPTION OF ALEURONE GRAINS}

The aleurone grains of curcas (Plate $77 a$, Fig. I) vary in form from circular to lens-shaped, and each grain contains one or more globoids. The globoids are larger when they occur singly. In sunflower seed (Plate 77a, Fig. 2) the grains vary from reniform to oval, and one or more globoids are present; many occur in the center of the grain.

The aleurone grains of flaxseed (Plate $77 a$, Fig. 3) resemble in form those of sunflower seed, but the grains are uniformly larger and some of the grains contain as many as five globoids.

In bitter almond (Plate $77 a$, Fig. 4) the aleurone grains are mostly circular, but a few are nearly lens-shaped. A few of the large, rounded grains contain as many as nine globoids; in such cases one of the globoids is likely to be larger than the others. The aleurone grains of croton-oil seed (Plate 77a, Fig. 5) are circular in outline, variable in form, and each grain contains from one to seven globoids.

In sesame seed (Plate 77a, Fig. 6) the typical grain is angled in outline and the large globoid occurs in the narrow or constricted end.

The aleurone grains of castor-oil seed (Plate $77 a$, Fig. 7) resemble those of sesame seed, but they are much larger, and many of the grains contain three large globoids. When these grains are mounted in sodium-phosphate solution, the crystalloid becomes visible.

\section{TESTS FOR ALEURONE GRAINS}

Aleurone grains are colored yellow with nitric acid and red with Millon's reagent.

The proteid substance of the mass of the grain, of the globoid, and of the crystalloid, reacts differently with different reagents and dyes.

The ground substance and the crystalloids are soluble in dilute alkali, while the globoids are insoluble in dilute alkali.

The ground substance and crystalloids are soluble in sodium phosphate, while the globoids are insoluble in sodium phosphate.

Calcium oxalate is insoluble in alkali and acetic acid, but it dissolves in hydrochloric acid. 


\section{PLATE $77 a$}
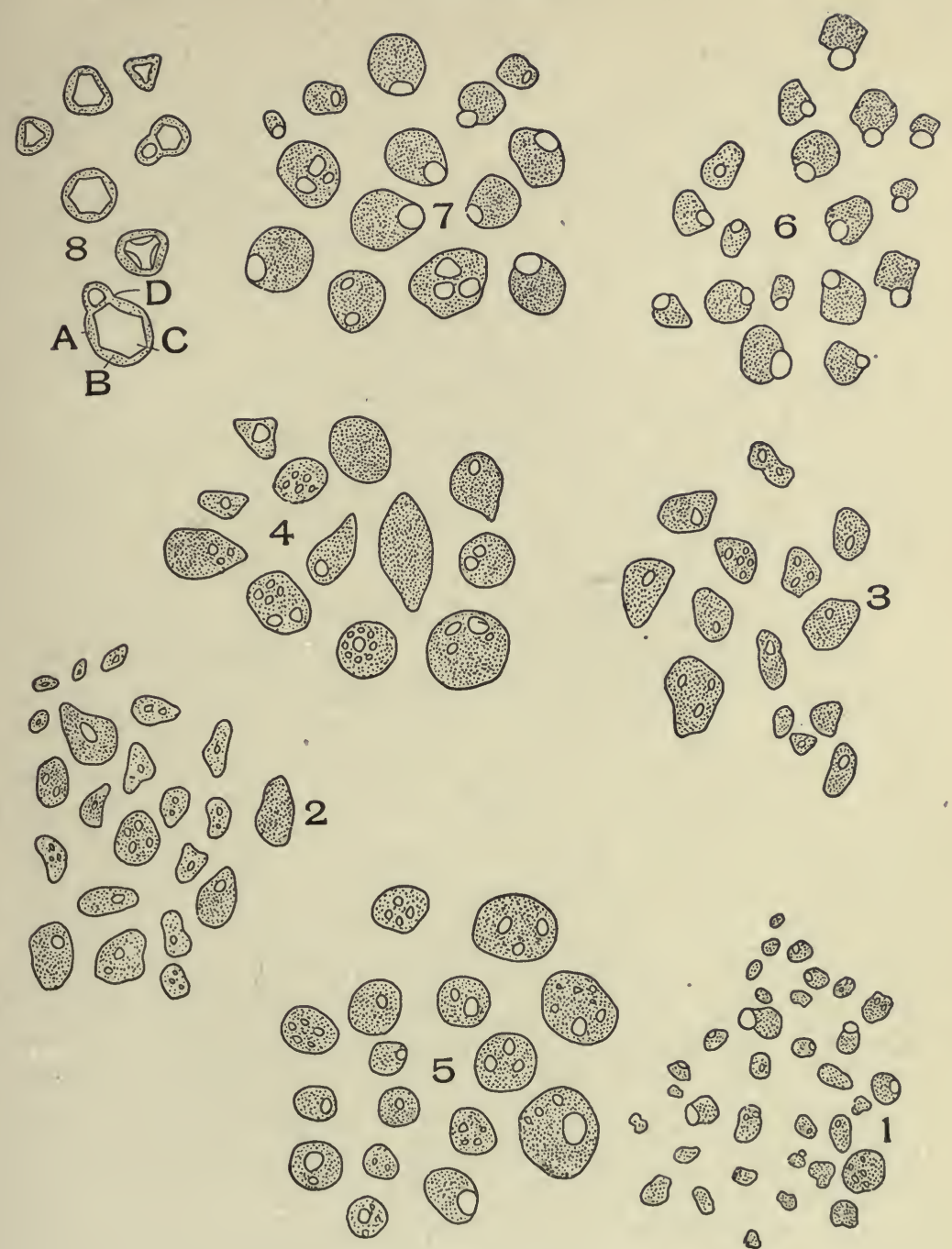

Aleurone Grains

I. Curcas (Jatropha curcas, L.).

2. Sunflower seed (Helianthus annuus, L.).

3. Flaxseed (Linum usitatissimum, L.).

4. Bitter almond (Prunus amygdalus, amara, D.C.).

5. Croton-oil seed (Croton tiglium, L.).

6. Sesame seed (Sesamum indicum, L.).

7 and 8. Castor-oil seed (Ricinus communis, L.). 


\section{CRYSTALS}

Calcium oxalate crystals form one of the most important inorganic cell contents found in plants, because of the permanency of the crystals, and because the forms common to a given species are invariable. By means of calcium oxalate crystals it is possible to distinguish between different species. In butternut root bark, for instance, only rosette crystals are found, while in black walnut root bark-a common substitute for butternut bark-both prisms and rosettes occur. This is only one of the many examples which could be cited.

These crystals, for purposes of study, will be grouped into four principal classes, depending upon form and not upon crystal system. These classes are micro-crystals, raphides, rosettes, and solitary crystals.

\section{MICRO-CRYSTALS}

Micro-crystals are the smallest of all the crystals. Under the high power of the microscope they appear as a V, a $\mathrm{Y}$, an $\mathrm{X}$, and as a T. They are, therefore, three- or four-angled (Plate 78). The thicker portions of these crystals are the parts usually seen, but when a close observation of the crystals is made the thin portions of the crystal connecting the thicker parts may also be observed. Micro-crystals should be studied with the diaphragm of the microscope nearly closed and with the highpower objective in position. While observing the micro-crystals, raise and lower the objective by the fine adjustment in order to bring out the structure of the crystal more clearly. Microcrystals occur in parenchyma cells of belladonna, scopola, stramonium, and bittersweet leaves; in belladonna, in horsenettle root, in scopola rhizome, in bittersweet stems, and in yellow and red cinchona bark, etc.

The crystals in each of the above parts of the plant are similar in form, the only observed variation being that of size. Their presence or absence should always be noted when studying powders.

\section{RAPHIDES}

Raphides, which are usually seen in longitudinal view, resemble double-pointed needles. They are circular in cross- 


\section{PLATE 78}

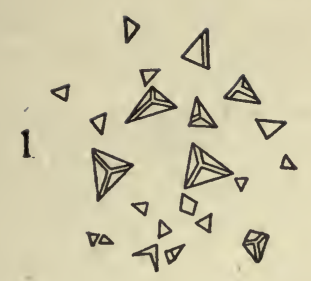

$\triangle$

$$
\begin{aligned}
& 6 \Delta \Delta \Delta \Delta \\
& \Delta \nabla_{\Delta} \nabla \Delta \Delta \\
& \theta \stackrel{\otimes \Delta}{\nabla} \nabla \nabla
\end{aligned}
$$

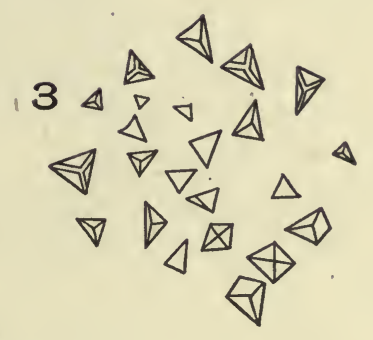

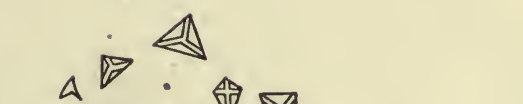

\section{5}

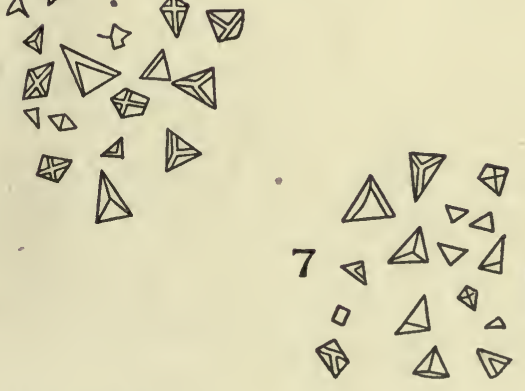

\section{Micro-Crystals}

I. Horse-nettle root (Solanum carolinense, L.).

2. Scopola rhizome (Scopola carniolica, Jacq.).

3. Belladonna root (Atropa belladonna, L.).

4. Bittersweet stem (Solanum dulcamara, L.).

5. Scopola leaf (Scopola carniolica, Jacq.).

6. Tobacco leaf (Nicotiana tabacum, L.).

7. Belladonna leaf (Atropa belladonna, L.). 
section, and the largest diameter is at the centre, from which they taper gradually toward either end to a sharp point.

Raphides occur in bundles, as in false unicorn root (Plate 79, Figs. 6, A, B, and C), rarely as solitary crystals.

In ipecac root the crystals are usually solitary. In sarsaparilla root, squill, etc., the raphides occur both in clusters, part of bundle, or in bundles, and as solitary crystals.

In most drugs the crystals are entire; but in squills, where the raphides are very large, they are broken. In phytolacca (Plate 79, Fig. I) and in hydrangea the raphides are usually broken, owing to the fact that these drugs contain large quantities of fibres which break them up into fragments when the drug is milled.

There is the greatest possible variation in the size of raphides in the same and in different drugs, but the larger forms are constant in the same species.

Raphides are deposited in parenchyma cells and in special raphides sacs. These crystals are always surrounded with mucilage.

\section{ROSETTE CRYSTALS}

Rosette crystals are compound crystals composed of an aggregation of small crystals arranged in a radiating manner around a central core. This core appears nearly black, and the whole mass is nearly spherical. The free ends of the crystals are sharp-pointed or blunt.

Characteristic rosette crystals occur in frangula bark, spikenard root, wahoo stem, root bark, rhubarb, etc. (Plate 80, Figs: I, 2, 3, 4, 5, and 6).

These crystals are very variable in size. This variation is illustrated by the crystals of Plate 80 .

Usually there is a variation in size of the crystals occurring in a given plant, but for each plant there is a more or less uniform variation. For instance, the largest rosette crystal occurring in wahoo root bark (Plate 8o, Fig. 5) is smaller than the largest crystal occurring in rhubarb (Plate 8o, Fig. 6), etc.

The prisms forming the rosette crystals, like all prisms, decompose white light, with the result that rosette crystals frequently appear variously colored. Rhubarb crystals, for 


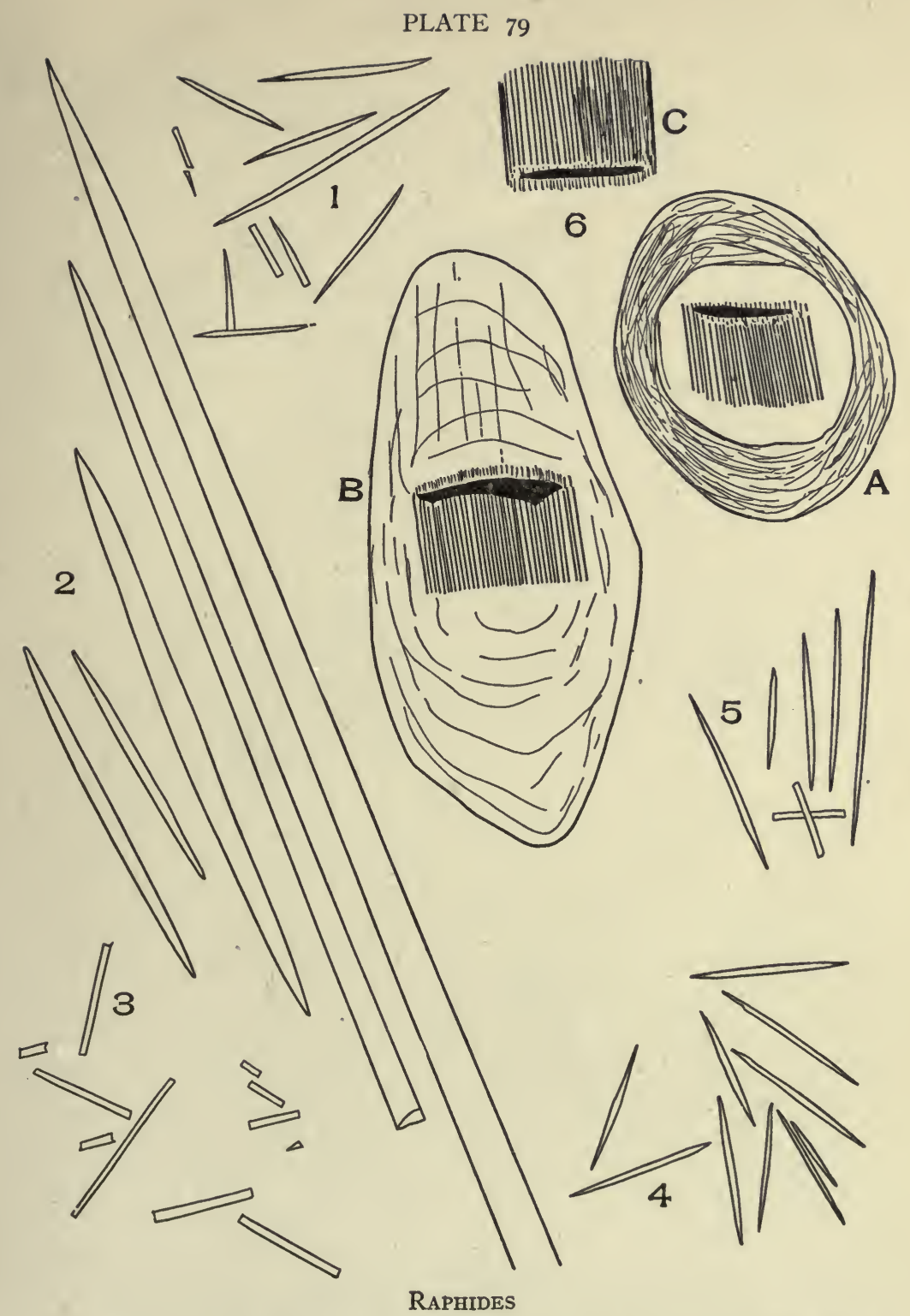

I. Phytolacca root (Phytolacca americana, L.). 2. Squills (Urginea maritima [L.] Baker). 3. Hydrangea root (Hydrangea arborescens, L.). 4. Convallaria (Convallaria majalis, L.). 5. Carthagean ipecac (Cephalis acuminata Karst.) 6. Bundle of raphides from false unicorn root.

A. Bundle surrounded with mucilage. B. Mucilage expanded and partially dissolved. C. Bundle free of mucilage. 

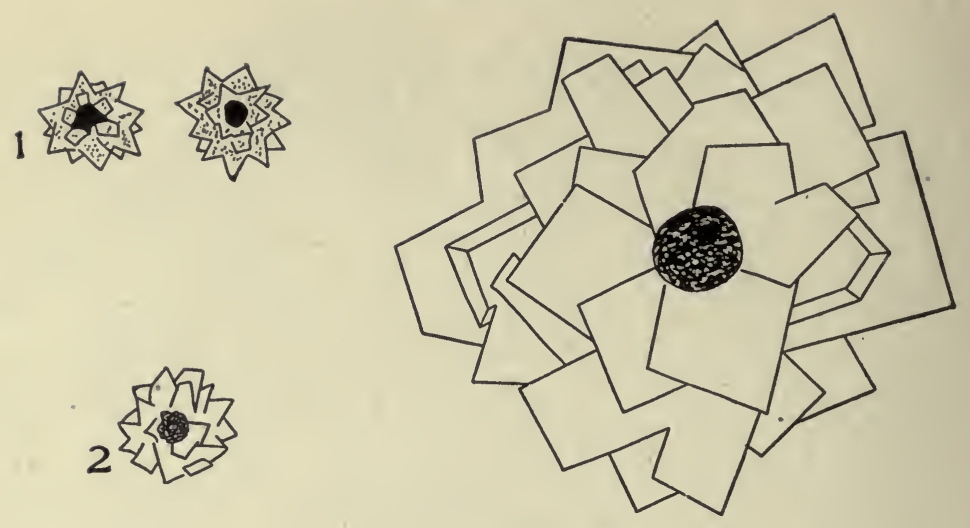

6
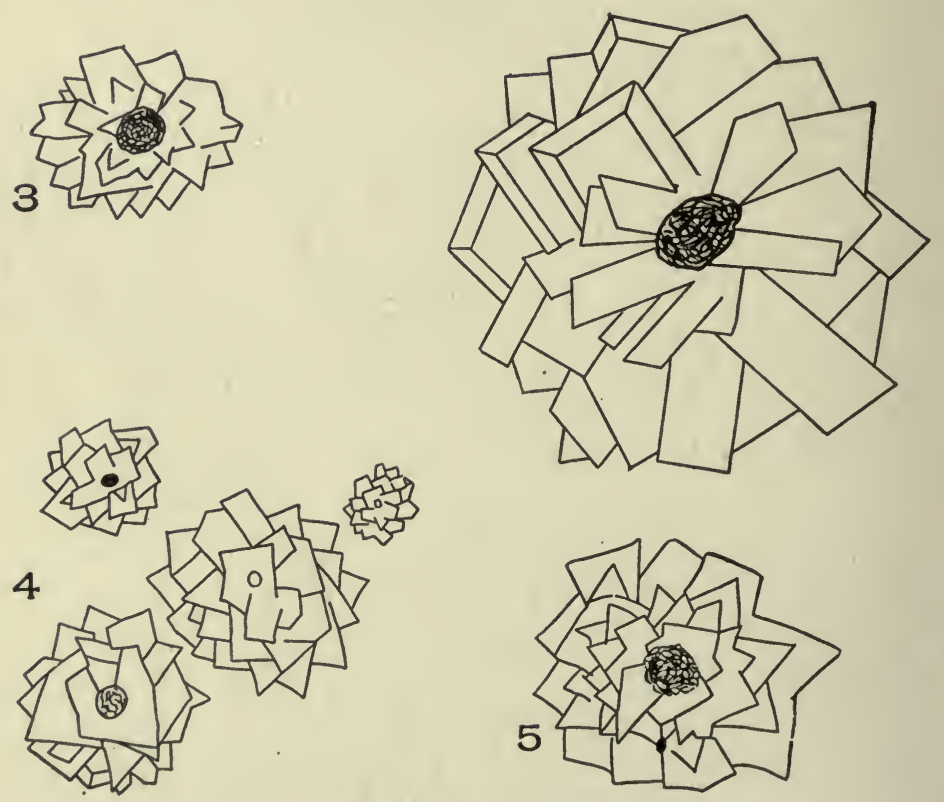

Rosette Crystals

I. Frangula bark (Rhamnus frangula, L.).

2. White oak bark (Quercus alba, L.).

3. Spikenard root (Aralia racemosa, L.).

4. Wahoo stem bark (Euonymus atropurpureus, Jacq.).

5. Wahoo root bark (Euonymus atropurpureus, Jacq.).

6. Rhubarb (Rheum officinale, Baill.). 
instance, are blue or violet. Most of the smaller rosette crystals, however, appear grayish white with a darker-colored centre.

Rosette crystals occur in parenchyma cells (Plate 8I, Fig. 4) and in medullary rays (Plate $8 \mathrm{r}$, Fig. 3 ).

\section{SOLITARY CRYSTALS}

Solitary crystals are the most variable of all the forms of calcium oxalate. They usually occur in crystal cells associated with bast fibres and stone cells, less frequently in stone cells (Plate 33, Fig. 2). There are many different and characteristic forms of prisms. The more common are:

I. Rectangular:

A. Parallelopipeds.

B. Cubes.

2. Polyhedrons:

A. Irregular polyhedrons.

I. Flat bases.

(a) Non-notched.

(b) Notched.

II. Tapering bases.

B. Octohedrons.

The crystals occurring in Batavia cinnamon and henbane leaves are parallelopipeds (Plate 82, Figs. I and 2).

The crystals occurring in cactus grandiflorus, hemlock bark, krameria root, and soap bark are irregular polyhedrons (Plate 83). They are longer than broad, and the ends are tapering. The crystal of cactus grandiflorus has the narrowest diameter of these four, while the crystals of soap bark have the widest diameter. In coca leaf, xanthoxylum bark, elm bark, Spanish licorice, and in white oak (Plate 84), and in cocillina bark (Plate 82 , Fig. 4) the crystals are all irregular polyhedrons with flat bases. They are mostly longer than broad and they are all widest in the centre; in each a few crystals are notched, but most of the crystals are not notched.

The crystals in quassia wood, uva-ursi leaf, and most of those of quebracho and wild cherry bark (Plate 86, Figs. I, 2, 3, and 4) are irregular polyhedrons with flat ends. They are longer than broad, widest at the centre, and non-notched.

Cubes occur in senna, cascara sagrada, frangula, white pine, 
PLATE 8I
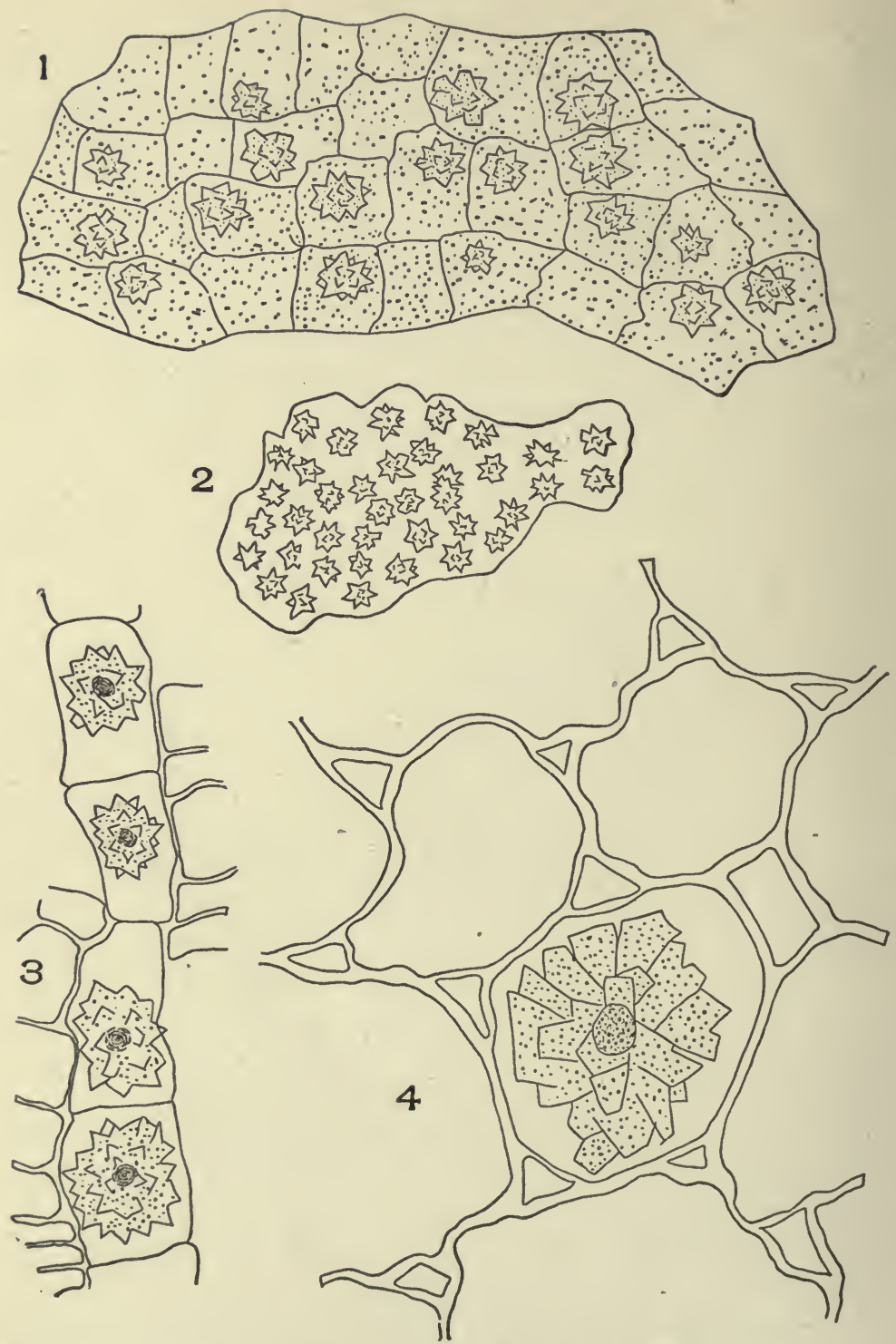

InClosed Rosette Crystals

I. Hops (Humulus lupulus, L.).

2. Bracts of cannabis indica (Cannabis sativa, variety Indica, Lamarck).

3. Medullary rays of canella alba.

4. Parenchyma cells of mandrake (Podophyllum peltatum, L.). 
PLATE 82

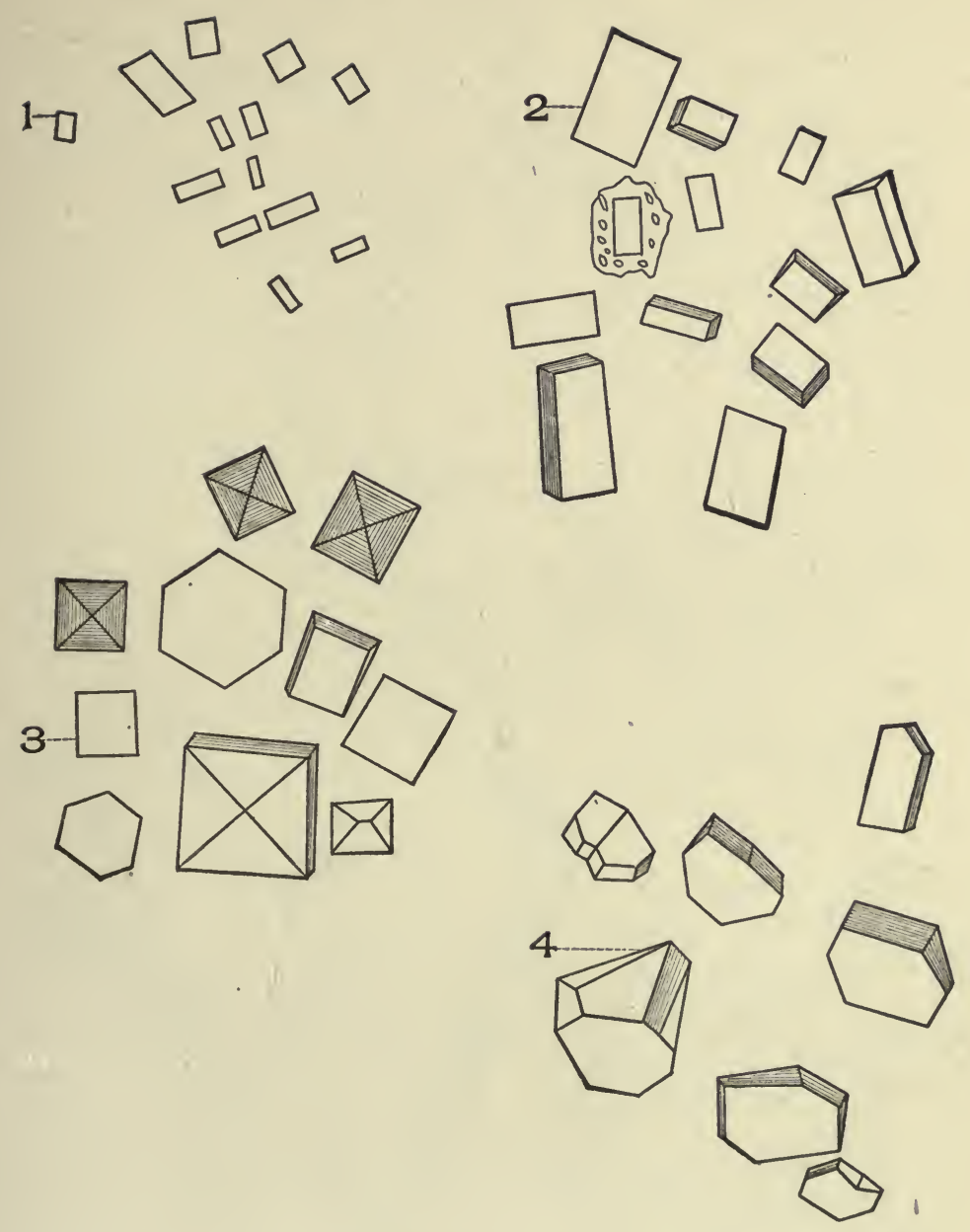

Solitary Crystal

I. Batavia cinnamon (cinnamomum burmanni, Nees).

2. Henbane leaves (Hyoscyamus niger, L.).

3. Morea nutgalls.

4. Cocillana bark (Guarea rusbyi [Britton], Rusby). 


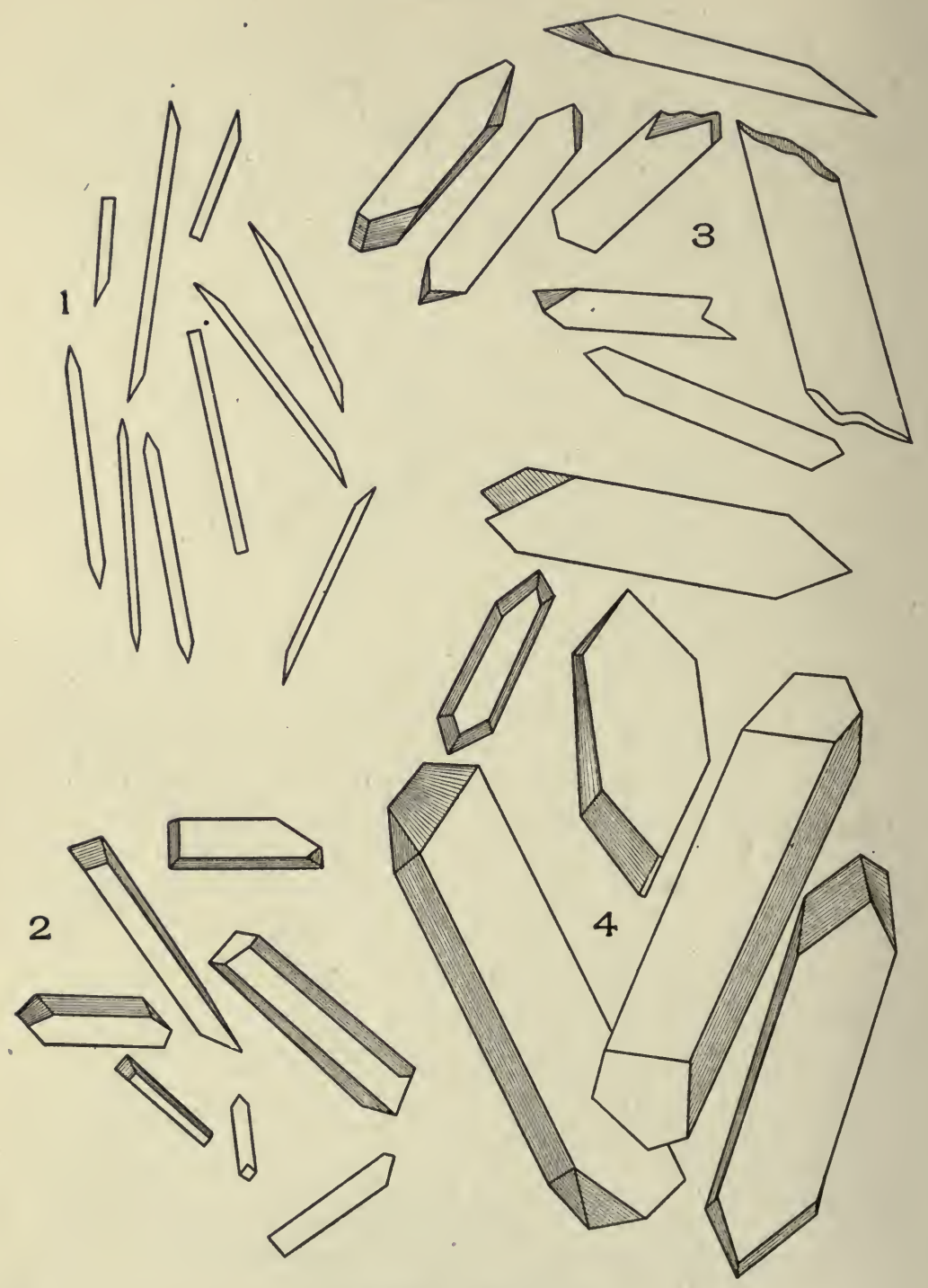

SOlitary Crystals

I. Cactus grandiflorus (Cerdus grandiflorus [L.], Britton and Rose).

2. Henlock bark (Tsuga canadensis [L.], Carr.).

3. Krameria root (Krameria triandra, Ruiz and Pav.).

4. Soapbark (Quillaja saponaria, Molina). 


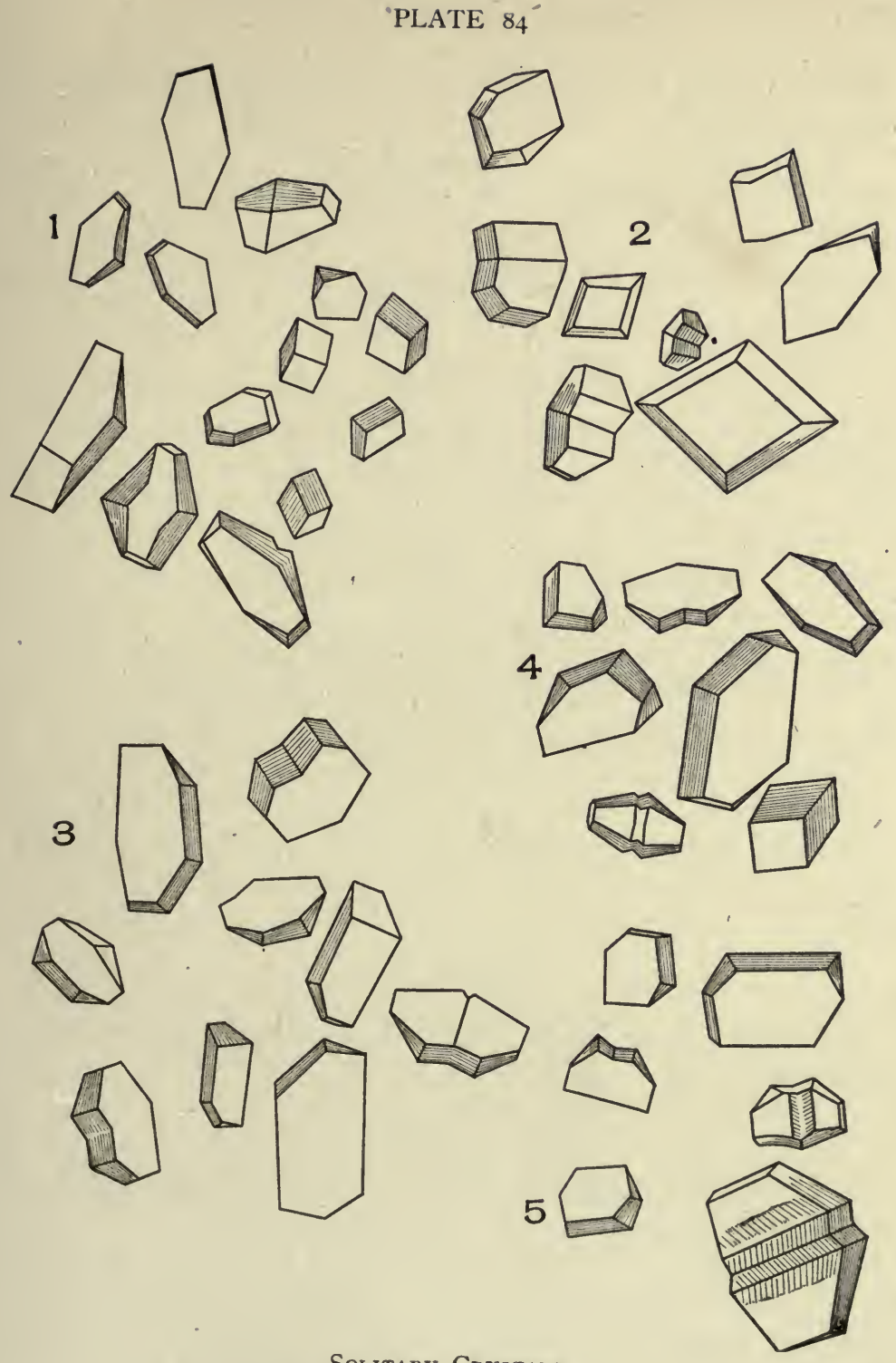

SOlitary CRYstals

I. Coca leaf (Erythroxylon coca, Lamarck).

2. Xanthoxylum bark (Zanthoxylum americanum, Miller).

3. Elm bark (Ulmus fulva, Michaux).

4. Spanish licorice root (Glycyrrhiza glabra, L.).

5. White oak bark (Quercus alba, L.). 
tamarac (Plate 85), quassia, uva-ursi, quebracho, and in wild cherry (Plate 86).

The crystals of morea nutgalls (Plate 82, Fig. 3) are octohedrons, and they resemble the crystals of calcium oxalate found in urinary sediments.

While studying the prisms, focus first on the upper surface and then down to the under surface in order to observe the forms accurately.

There are several plants in which more than one form of crystal occur. Rosette crystals and prisms are associated, for instance, in cascara sagrada, frangula, condurango, dogwood, and pleurisy root (Plate 87, Figs. I, 2, 3, 4, and 5).

An important factor to be kept in mind in studying crystals is the number-whether abundant, as in rhubarb, or sparingly present, as in mandrake, etc. Variation in the number of crystals is not uncommon, even in different parts of the same plants. In wahoo stem bark, for instance, there are several times as many rosette crystals as there are in the root bark.

Crystals of calcium oxalate are freely soluble in dilute hydrochloric acid without effervescence; but they are insoluble in acetic acid and in sodium and potassium hydroxide solutions. With sulphuric acid they form crystals of calcium sulphate.

\section{CYSTOLITHS}

Cystoliths consist of calcium carbonate deposited over and around a framework of cellulose.

\section{FORMS OF CYSTOLITHS}

The forms of cystoliths differ greatly in the different plants in which they occur.

In the rubber-plant leaf, the cystolith resembles a bunch of grapes and is stalked; in ruellia root (Plate 87, Fig. I) the cystoliths vary from nearly circular to narrowly cylindrical, and no stalk is present; also the cystolith nearly fills the cell in which it occurs. In the hair of cannabis indica (Plate 88, Fig. 3), the cystolith varies in form according to the size and shape of the hair, but in all the hairs the cystolith appears to be attached to the upper curved part of the inner wall of the hair. 
PLATE 85
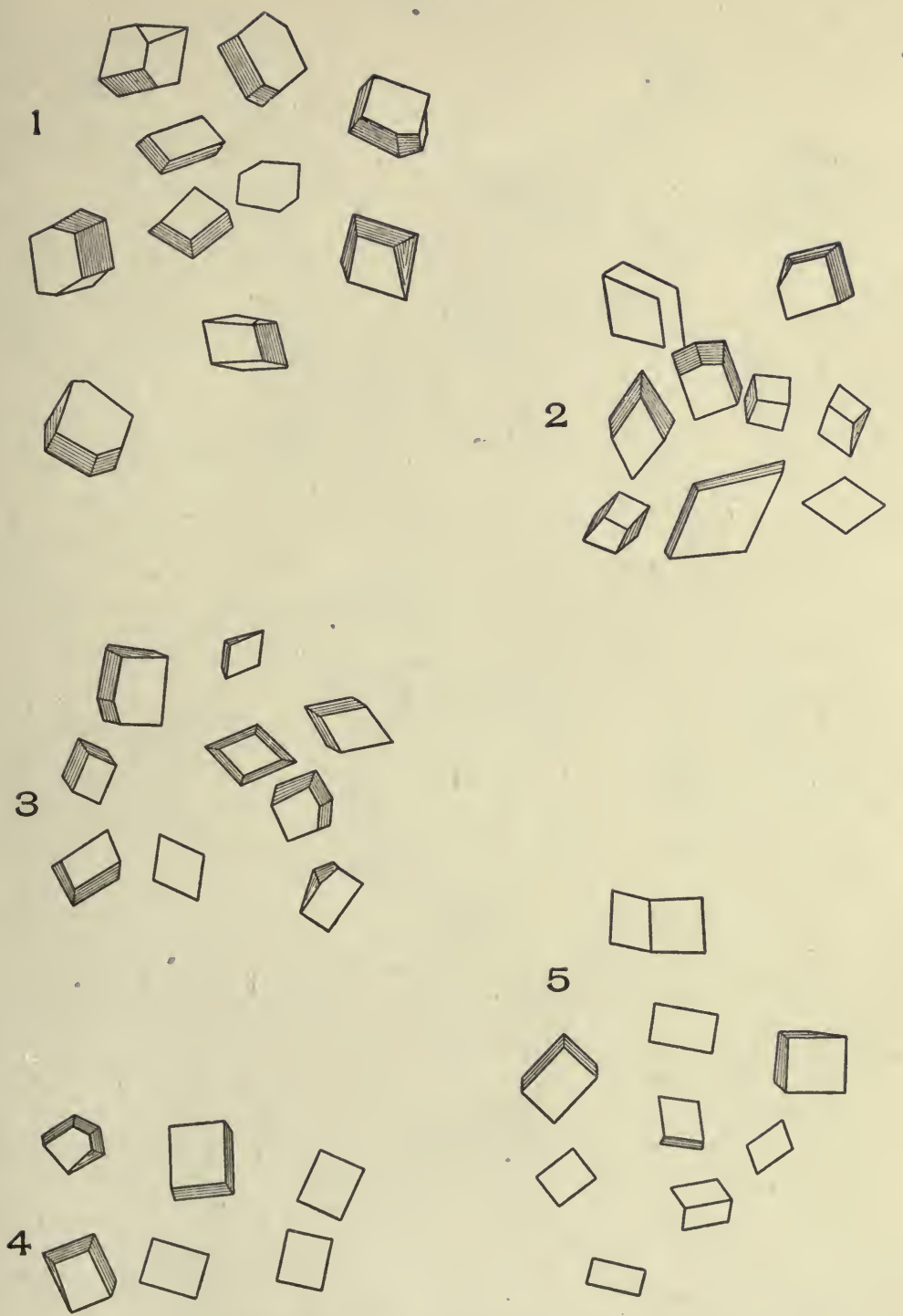

Solitary Crystals

I. India senna (Cassia angustifolia, Vahl.).

2. Cascara sagrada bark (Rhamnus purshiana, D. C.).

3. Frangula bark (Rhamnus frangula, L.).

4. White pine bark (Pinus strobus, L.).

5. Tamarac bark (Larix laricina [Du Roi], Koch). 
PLATE 86
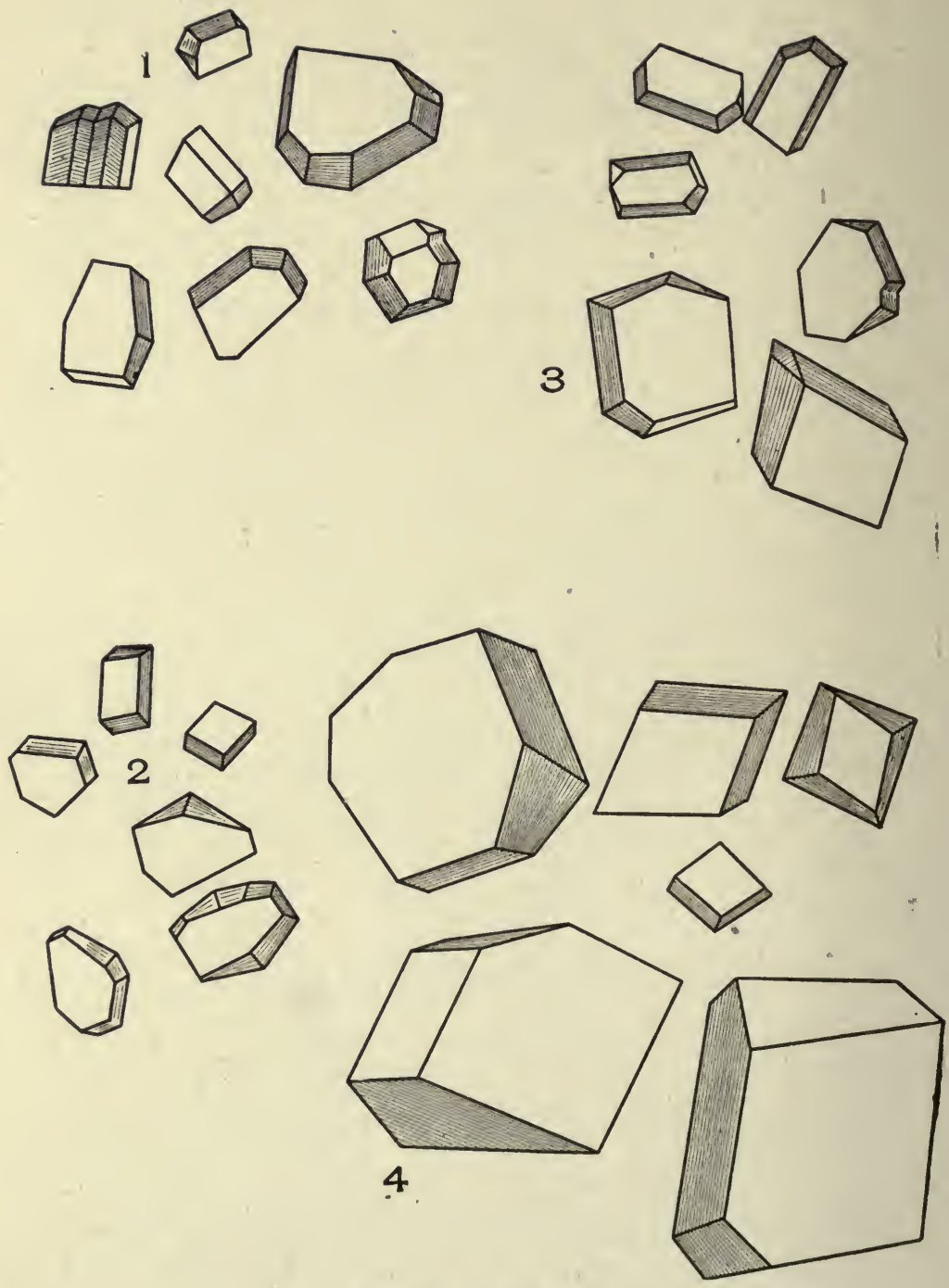

Solitary Crystals

I. Quassia (Picrcena excelsa [Swartz.], Lindl.).

2. Uva-ursi leaf (Arctostaphylos uva-ursi [L.], Spring.).

3. Quebracho bark (Aspidosperma quebracho-blanco, Schlechtendal).

4. Wild-cherry bark (Prunus serotina, Ehrh.). 


\section{PLATE 87}
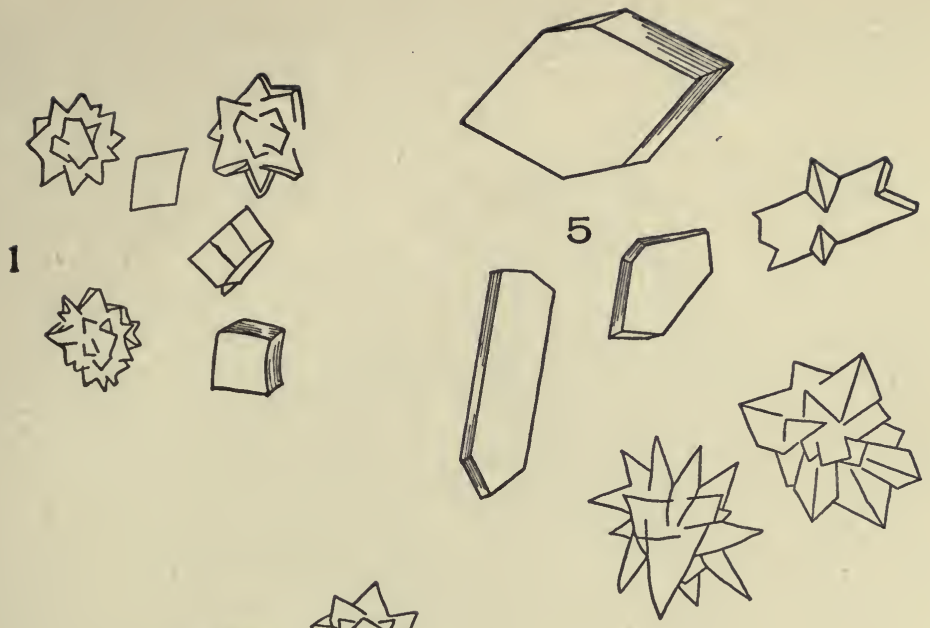

20 约然
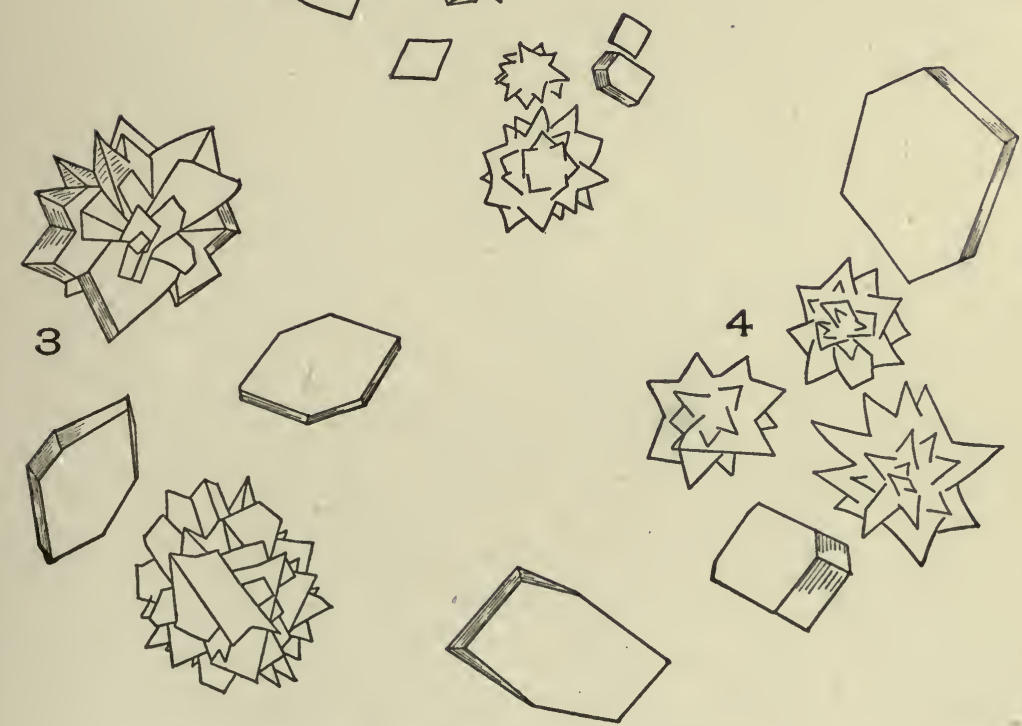

Rosette Crystals and Solitary Crystals Occurring in

I. Cascara sagrada bark (Rhamnus purshiana, D.C.).

2. Frangula bark (Rhamnus frangula, L.).

3. Cundurango bark (Marsdenia cundurango, [Triana] Nichols).

4. Dogwood root bark (Cornus florida, L.).

5. Pleurisy root (Asclepias tuberosa, L.). 
PLATE 88

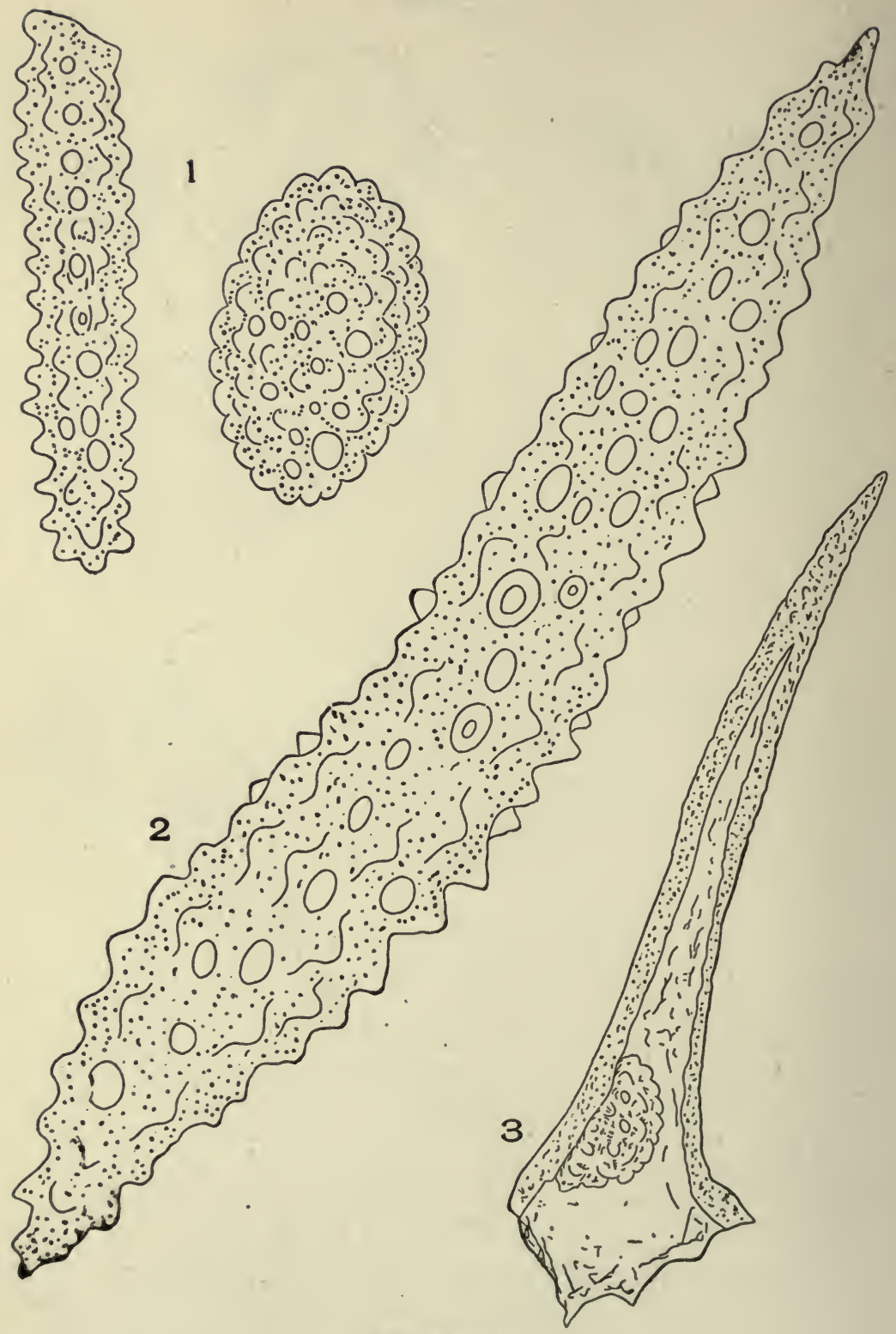

Cystoliths

I. Ruellia root (Ruellia ciliosa, Pursh.).

2. Pellionia leaf.

3. Cannabis indica (Cannabis sativa, variety Indica, Lam.) 
Cystoliths occur, then, in special cavities, in parenchyma cells (rubber-plant leaf, fig, pellionea, and mulberry), and in non-glandular hairs (cannabis indica).

In powdered ruellia root the cystoliths occur in or are separated from the parenchyma cells.

\section{TESTS FOR CYSTOLITHS}

When dilute hydrochloric acid or acetic acid is added to cystoliths a brisk effervescence takes place with the evolution of carbon dioxide gas. 



\section{Part III}

\section{HISTOLOGY OF ROOTS, RHIZOMES, STEMS, BARKS, WOODS, FLOWERS, FRUITS, AND SEEDS}

In Part II the different types of cells and cell contents found in plants have been studied. In Part III it will be shown how these different cells are associated and the nature of the cell contents in the different parts of the plant. These parts are the root, the rhizome, the stem of herbs, bark and wood of woody stems, the leaf, the flower, the fruit, and the seed. 



\section{CHAPTER I}

\section{ROOTS AND RHIZOMES}

Some fifty-five roots, rhizomes, and rhizomes and roots are official in the pharmacopœia and national formulary. About 5 of these are obtained from monocotyledonous plants, and 50 from dicotyledonous plants.

In studying the structure of roots and rhizomes, then, it must first be determined whether the root in question is monocotyledonous or dicotyledonous. This fact is ascertained by determining the type of the fibro-vascular bundle. The bundle is of the open collateral type in all rhizomes and roots obtained from monocotyledonous plants, but it is closed, radial, or concentric in the monocotyledonous type.

In both of these groups the cellular plan of structure is similar, the chief variation being the absence of one or more types of cells, the variation in the amount, in arrangement, in the anatomical structure, in the color, and in the cell contents of the individual cells. These facts will be impressed on the mind while studying the rhizomes and the roots.

\section{CROSS-SECTION PINK ROOT}

The cross-section of pink root (Plate 89) has the following structure:

Epidermis. The epidermal cells are small, nearly as long as broad, and the outer wall is thicker and darker in color than the side and inner walls. The cells usually contain air.

Cortex. The cortical parenchyma cells are very large and somewhat rounded in outline, and the walls are white. There are about twelve rows of these cells, and each cell contains numerous small, rounded starch grains.

Endodermis. The endodermal cells are tangentially elongated, and the walls are very thin and white. There are two or three layers of endodermal cells; the cells' outer layers are larger than the cells of the inner layers. 


\section{PLATE 89}

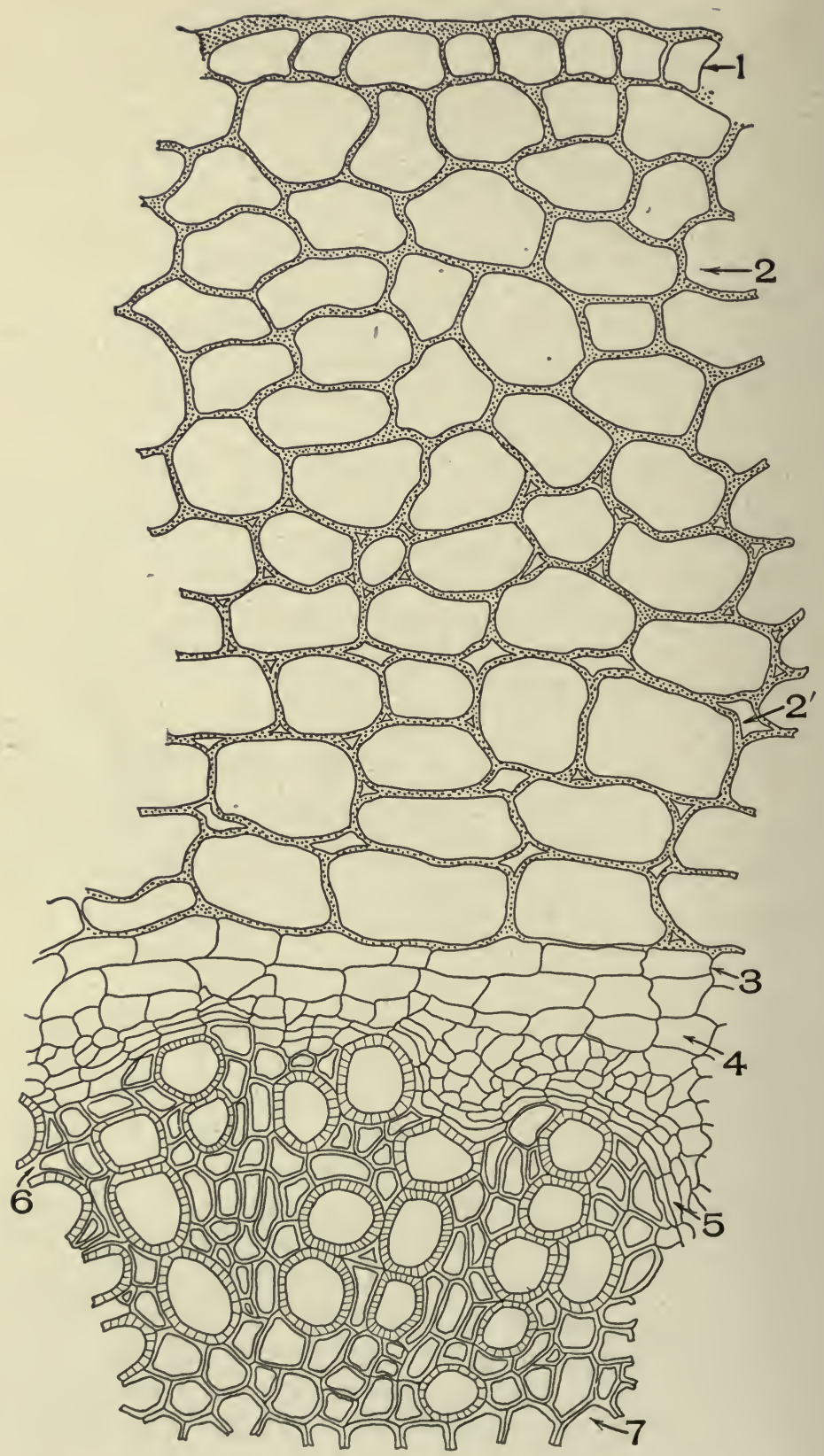

Cross-section of Root of Spigelia marylandica, L.

I. Epidermis. 2. Cortical parenchyma. 2'. Intercellular space. 3. En- • dodermis. 4. Pericycle. 5. Cambium. 6. Xylem. 7. Pith. 
Pericycle. The cells forming the pericycle are sieve cells and phloem parenchyma. The sieve cells are small, angled cells with extremely thin, white walls.

The phloem parenchyma resemble the sieve cells, except that they are larger.

Cambium. The cambium cells are rectangular in shape; the walls are thin and white.

Xylem. The xylem is composed of tracheids, wood parenchyma, and wood fibres.

Tracheids. The tracheids are the largest diameter cells of the centre of the root. The walls are thick and the cells are slightly angled in outline.

Wood Parenchyma. The wood parenchyma cells surrounding the tracheids are five to seven, angled, and the walls are not so thick as the walls of the tracheids.

Medullary Rays. The medullary ray cells resemble the structure of the wood parenchyma cells, but they are radially elongated.

Pith Parenchyma. The cells forming the pith parenchyma are larger than the cells of wood parenchyma, but their structure is similar.

\section{CROSS-SECTION RUELLIA ROOT}

The cross-section of ruellia root (Plate 90) shows the following structure. It should be carefully noted how the structure differs from that of pink root:

Epidermis. The epidermal cells are angled and variable in size; many of the epidermal cells are modified as root hairs.

Hypodermis. The cells of the hypodermis are one layer in thickness and their structure is similar to the epidermal cells.

Cortex. The cortex contains parenchyma and stone cells. The outer layers of the cortical parenchyma cells are round in outline, and they contain dark-brown cell contents, while the cortical parenchyma cells bordering on the endodermis are small and they are free of dark-brown contents.

Many of the inner parenchyma cells contain amorphous deposits of calcium carbonate. 


\section{PLATE 90}

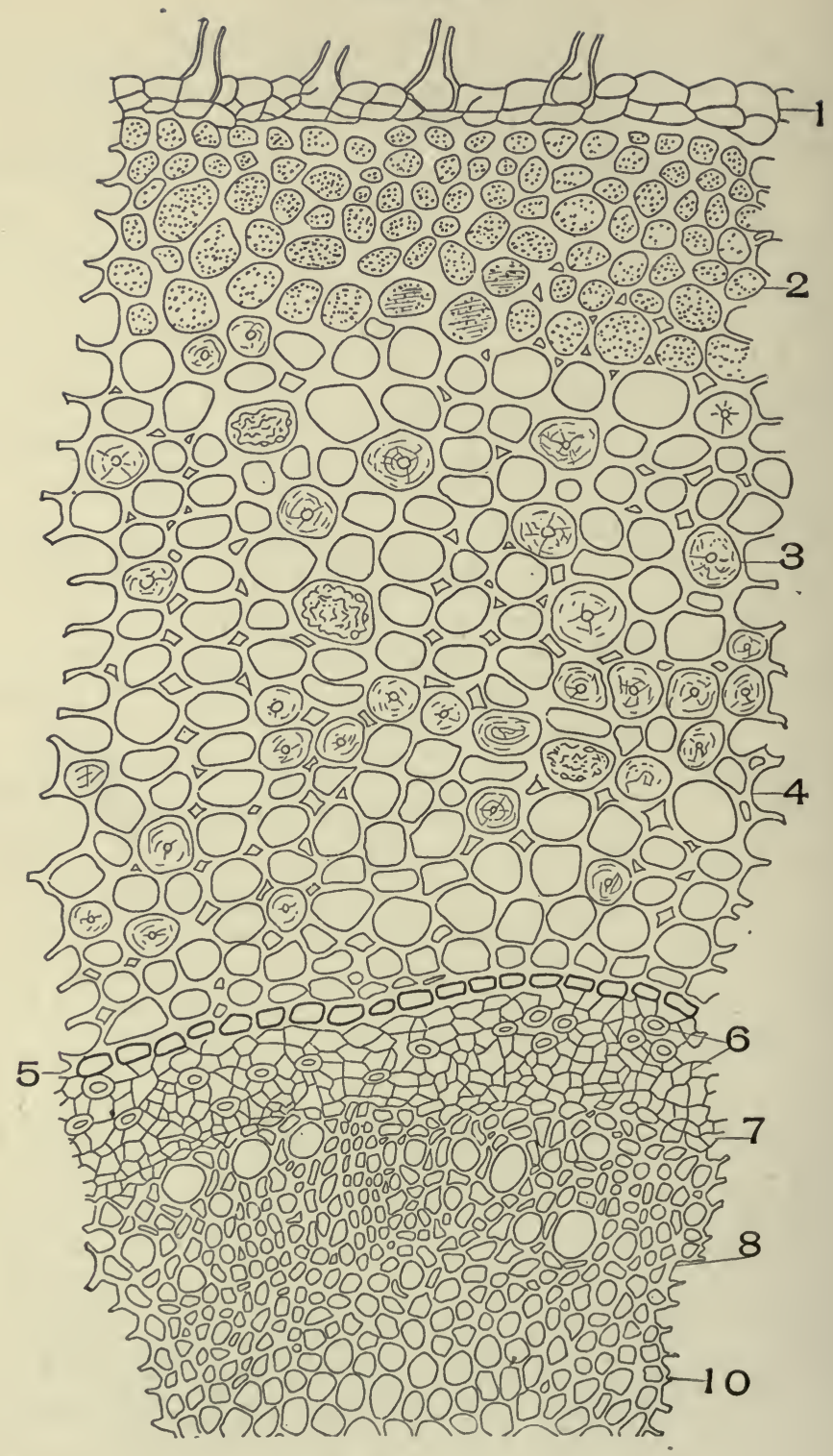

Ruellia Root (Ruellia ciliosa, Pursh.).

I. Epidermis with root hair. 2. Parenchyma cells with dark contents. 3. Sclerid. 4. Parenchyma without dark cell contents. 5. Enflodermis. 6. Bast fibers and phloem. 7. Camlium. 8. Xylem. I0. Pith. 
The stone cells are porous and striated, and the walls are thick and white.

Endodermis. The endodermal cells are tangentially elongated, and the walls are thin and white.

Pericycle. The cells forming the pericycle are the sieve cells, bast fibres, and phloem parenchyma.

The sieve cells are small, angled cells with thin, white walls,

The phloem parenchyma cells resemble the sieve cells, but they are larger.

The bast fibres occur singly or in groups of two or three. They are rounded in outline, and the walls are white, nonporous, and non-striated.

Xylem. The xylem is composed of vessels, wood parenchyma, and wood fibres.

Vessels. The vessels are rounded in outline and few in number.

Wood Parenchyma. The wood parenchyma cells are variable in size and shape, but all the cells are angled in outline.

Medullary Rays. The medullary ray cells are not clearly distinguishable.

Pith Parenchyma. The pith parenchyma cells of the centre of the root resemble the cortical parenchyma cells.

That the structure of rhizomes is similar to the structure of roots is shown by the drawings of spigelia rhizome (Plate 9r), and by ruellia rhizome (Plate 92).

\section{CROSS-SECTION SPIGELIA RHIZOME}

The cross-section of spigelia rhizome (Plate 9r) is as follows:

Epidermis. The epidermal cells are nearly angled and free of cell contents.

Cortex. The cortical parenchyma cells are usually slightly tangentially elongated. The cells of the outer layers are larger than the cells of the inner layers.

Phloem. The phloem contains sieve cells and phloem parenchyma. The sieve cells are small, angled cells with thin, white walls.

The phloem parenchyma cells resemble the sieve cells, but they are larger.

Cambium. The cambium cells are rectangular, and they are 


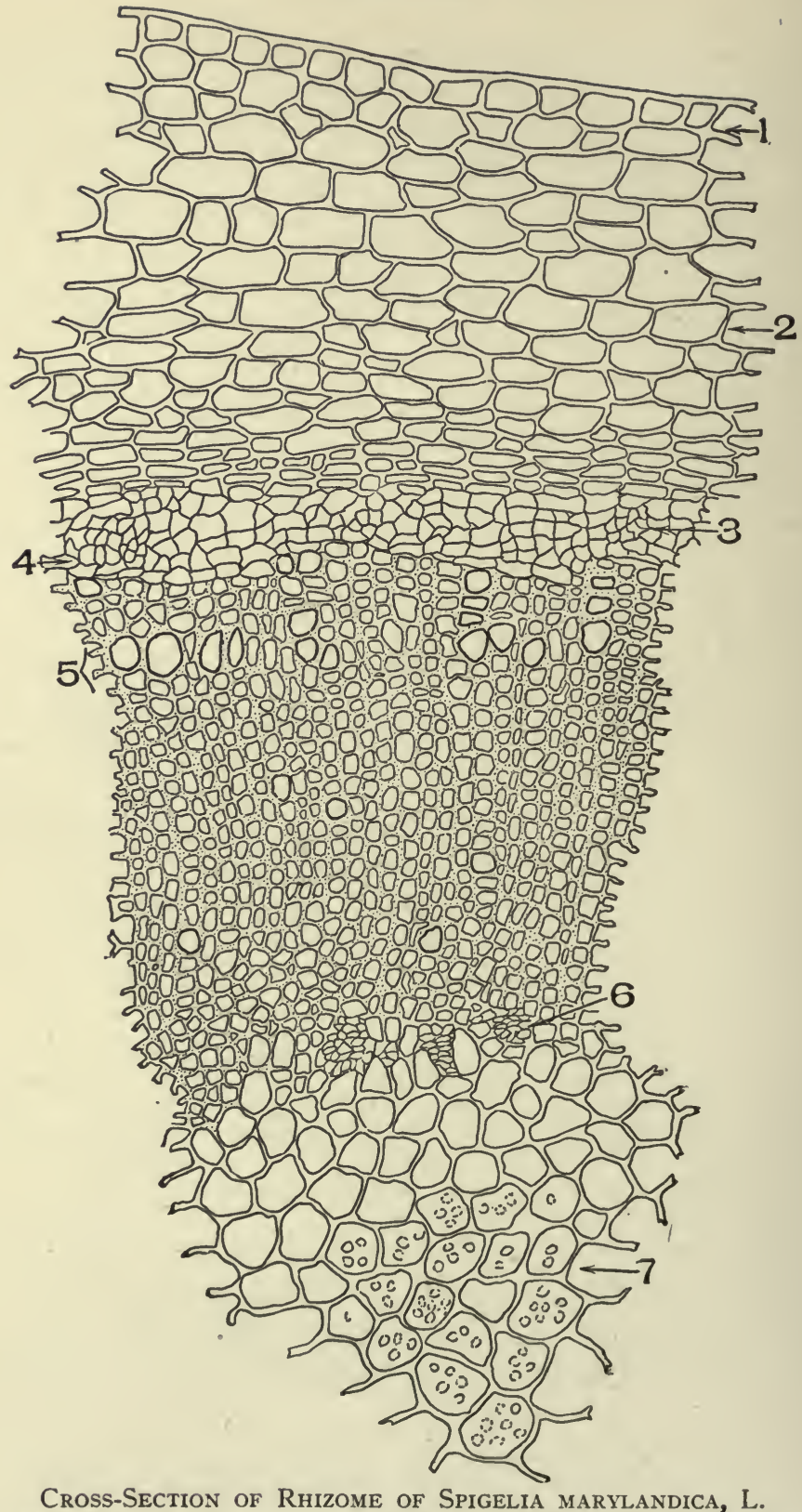

I. Epidermis. 2. Cortical parenchyma. 3. Phloem. 4. Cambium. 5. Xylem. 6. Internal phloem. 7. Pith with starch. 


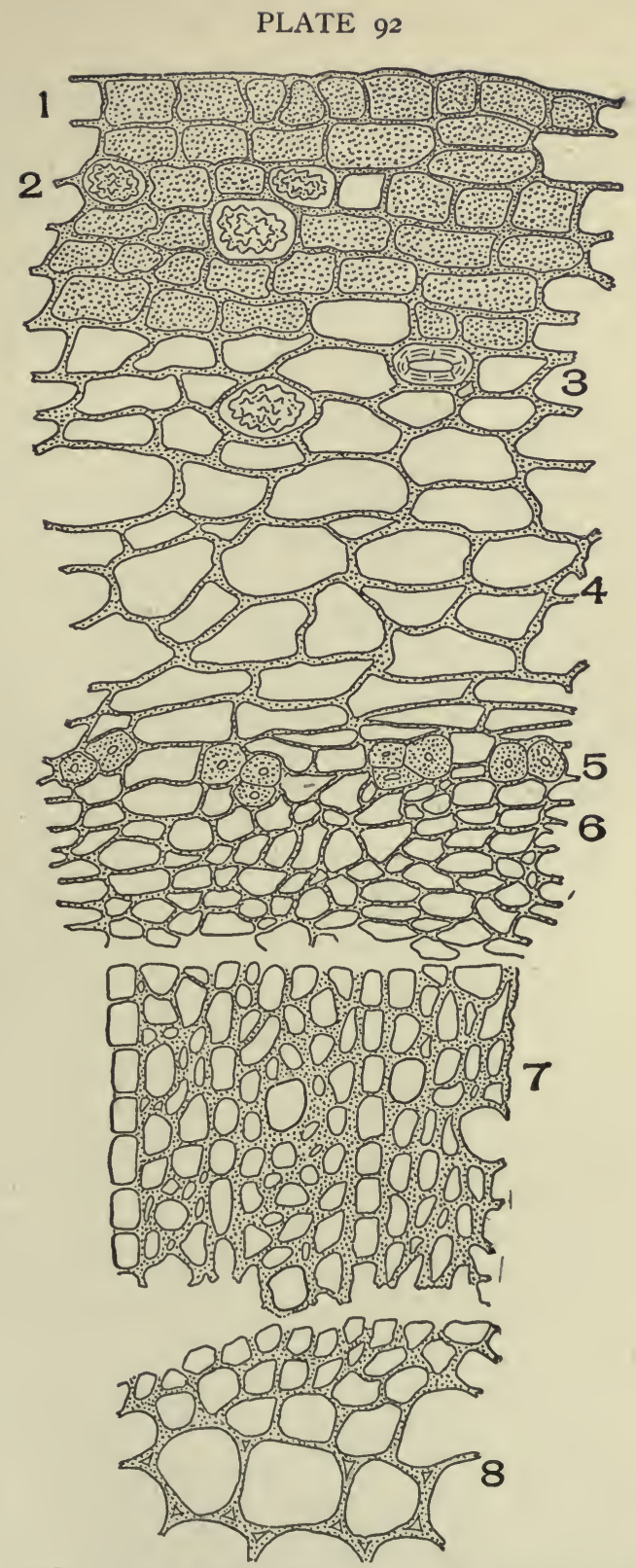

Cross-Section of Rhizome of Ruellia ciliosa, Pursh.

I. Epidermis. 2. Cystolith. 3. Stone cell. 4. Cortical parenchyma. 5. Bast fibres. 6. Pericycle. 7. Xylem. 8. Pith. 
usually not clearly seen because the walls are partially collapsed.

Xylem. The xylem is composed of vessels, wood parenchyma, medullary rays, and pith parenchyma.

Vessels. The vessels are slightly angled in outline and few in number.

Wood Parenchyma. The wood parenchyma cells are small and angled.

Medullary Rays. The medullary ray cells are tangentially elongated, but in structure resemble the wood parenchyma cells.

Pith Parenchyma. The pith parenchyma cells are rounded in outline and contain small, simple, rounded starch grains.

\section{CROSS-SECTION RUELLIA RHIZOME}

The cross-section of ruellia rhizome (Plate 92) differs from the structure of spigelia rhizome. It is as follows:

Epidermis. The epidermal cells vary in shape from nearly square to oblong, and they are filled with dark-brown cell contents.

Cortex. The cortex contains parenchyma and stone cells.

The outer layer of the cortical parenchyma cells are variable in size and many of the cells contain deposits of calcium carbonate and dark cell contents; the inner parenchyma cells are larger and they are free of the dark-brown cell contents, but many of the cells contain deposits of calcium carbonate.

Stone cells with thick, white, porous, and striated walls occur in among the cortical parenchyma cells.

Phloem. The phloem contains sieve cells, phloem, parenchyma, and bast fibres.

The sieve cells are small and with thin, white, angled walls.

The phloem parenchyma cells resemble the sieve cells, but they are larger.

The bast fibres occur singly or in groups of two or three. The walls are white, non-porous, and non-striated.

Cambium. The cambium layer is composed of rectangularly shaped cells, which are frequently obliterated.

Xylem. The xylem contains vessels, wood parenchymá, and medullary rays.

The vessels are large, rounded cells with thick walls. 
The wood parenchyma consists of thick-walled cells of irregular size and form.

The medullary rays are tangentially elongated and rectangular in form.

Pith parenchyma. The pith parenchyma cells are rounded in outline and as large as the cortical parenchyma cells.

\section{POWDERED PINK ROOT}

When the roots and rhizomes of spigelia are powdered (Plate 93) they show the following structure:

The epidermal cells are small and brownish on surface view, varying in size from $\mathrm{I} 3$ by $\mathrm{I} 8$ micromillimeters to $3 \mathrm{I}$ by 40 micromillimeters. When associated with parenchyma they appear as black masses. The cortical parenchyma cells are rounded and vary in size from 23 by 26 micromillimeters to 37.5 by 90 micromillimeters. Many of the cells from the root contain larger quantities of minute single rounded starch grains varying in size from I micromillimeter to 4 micromillimeters. The larger round single starch grains are found in both the cortical and pith parenchyma of the rhizome. They vary in size from 5 micromillimeters to 18 micromillimeters. The conducting elements are pitted tracheids varying from to micromillimeters to 38 micromillimeters in diameter. A few pitted and annular vessels are also found. The only fibres occurring are found in the xylem. They are not a prominent feature of the powder, as their walls break up into minute fragments. The pith parenchyma varies in size from $\mathrm{I}_{3}$ by $\mathrm{I} 9$ micromillimeters to 75 by 82.5 micromillimeters. It is in these cells that the largest starch grains occur.

Distinguishing diagnostic characters of the powder:

I. Parenchyma with starch.

2. Dark masses of epidermal tissue.

3. Spigelia should contain starch, and it should not contain cystoliths, stone cells, or long, white-walled bast fibres.

\section{POWDERED RUELLIA ROOT}

When the roots of ruellia root and rhizome are powdered (Plate 94) they show the following structure:

The epidermal cells vary from 7.8 by 15.6 micromillimeters 
PLATE 93
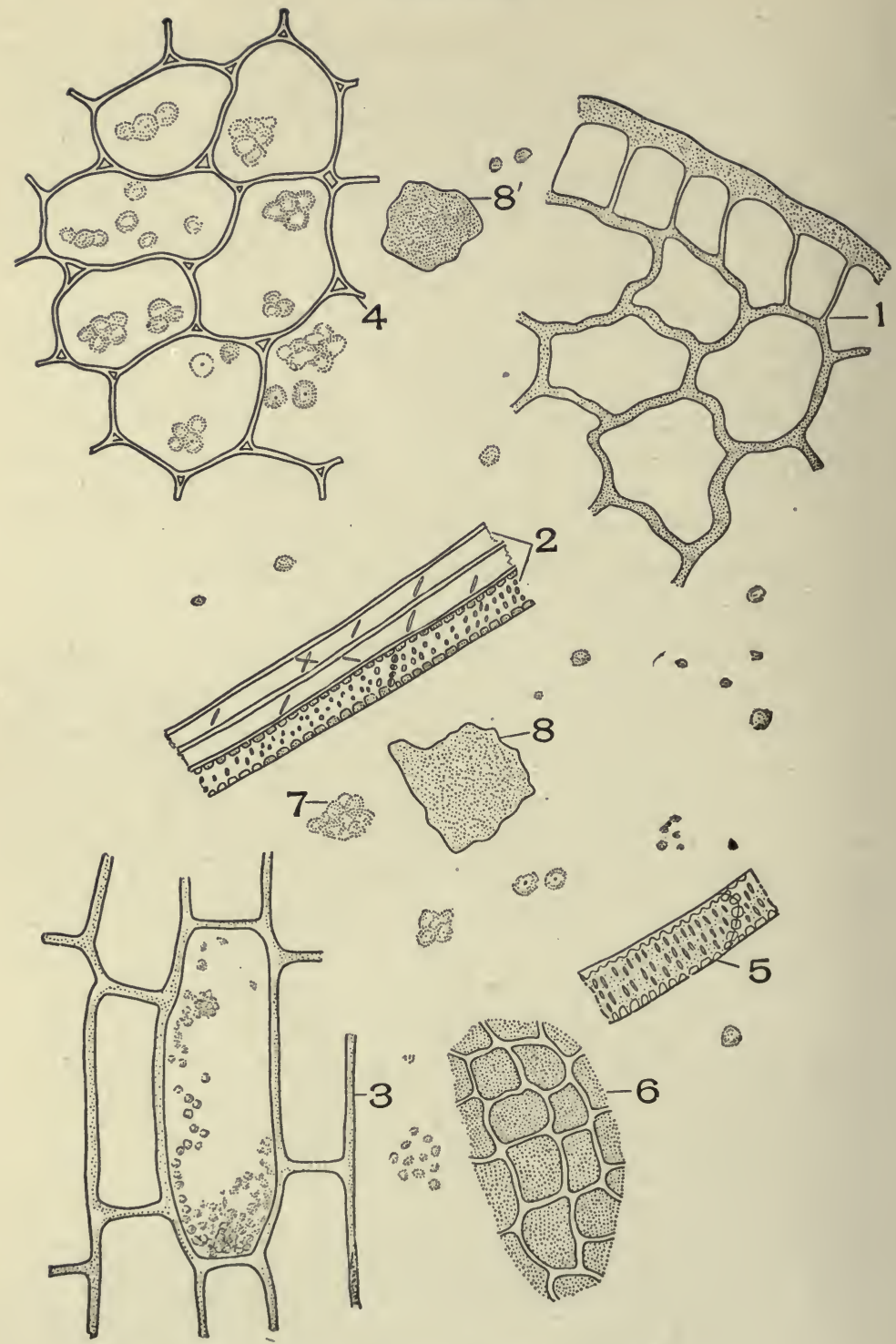

Powdered Spigelia marylandica, L.

I. Epidermis and cortical parenchyma. 2. Tracheids and fibres. 3. Parenchyma cells of the root containing the small starch grains, longitudinal view. 4. Parenchyma of the rhizome containing the large starch grains, transverse view. 5. Tracheids. 6. Surface view of the epidermal cells. 7. Starch scattered through the field. 8 and 8 '. Dark masses of epidermal and underlying tissue. 
PLATE 94

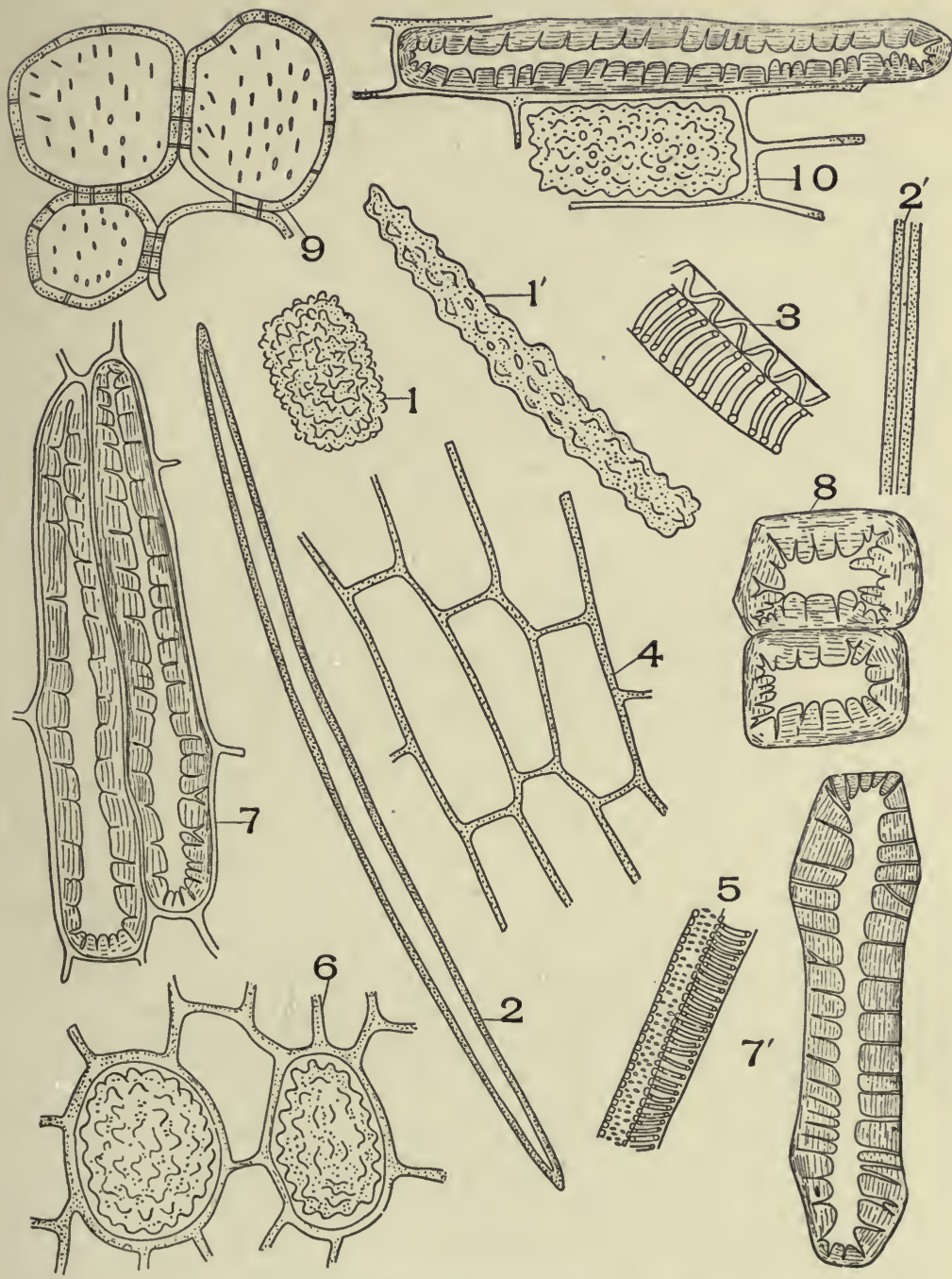

Powdered Ruellia ciliosa, Pursh.

I. Short, broad cystoliths from the rhizome. I'. Long cystoliths from the root. 2 and $2^{\prime}$. Long, narrow, white-walled bast fibres. 3. Tracheal tissue from the xylem of the stem. 4. Root parenchyma. 5. Tracheal tissue from the xylem of the root. 6. Cortical parenchyma cells from the rhizome with short, broad cystoliths, 7 and $7^{\prime}$. Long, thick-walled sclerids from the root. 8. Short, broad sclerids from the stem. 9. Pitted pith parenchyma from the stem with intercellular space. Io. Parenchyma of the root with sclerid and cystolith, longitudinal view. 
to I5.I by 16.6 micromillimeters. The cell contents are dark and the walls are light. A few rows of the outer cortical parenchyma cells of both the rhizome and the root have dark cell contents and white walls. The dark contents disappear toward the phloem. The cortical cells vary from 13.6 by 14.3 micromillimeters to 89.5 by 90.9 micromillimeters. In the cortical parenchyma cells of the rhizome are found the short, broad cystoliths measuring up to 52 by 62 micromillimeters. In the corresponding cells of the root are found the long, narrow cystoliths which measure up to 68.4 by 187.2 micromillimeters. Scattered throughout the powder are seen three distinct types of sclerids (stone cells) which are associated with the cortical parenchyma of both the stem and the root. Most of them are found, however, in the roots. First, the short, broad stone cells from the stem basis have square ends; the walls vary from I3 to 19.5 micromillimeters in thickness with branching pores which extend toward the adjacent cell. These sclerids vary in size from $5^{2}$ by 54.6 micromillimeters to 45 by 130 micromillimeters. Secondly, the long stone cells from the root vary from 32 by 96 micromillimeters to 45.5 by 542.5 micromillimeters with walls 16 micromillimeters thick. The width of the cell and the thickness of the wall vary but little throughout their entire length. The third type of stone cell also from the root has unequally thickened walls and the ends are square or blunt. A few long, narrow, colorless, thin-walled bast fibres also occur. They are I3 micromillimeters wide, with walls 3.9 micromillimeters thick. Annular spiral and pitted vessels are also found scattered throughout the powder.

The diagnostic characters of the powder are:

I. The short, broad, and long, narrow cystoliths.

2. The short, broad, and long, narrow sclerids.

3. The long, narrow, thin, white-walled bast fibres.

In poke root, ipecac, sarsaparilla, and veratrum are raphides. In belladonna and horse-nettle roots are micro-crystals. In calumba, stillingea, krameria, licorice, scamony root are prisms. In saponaria, jalap, althea, spikenard, rumex, rhubarb are rosette crystals. In pleurisy roots both prisms and rosettes occur.

In gentian, senega, symphytuns, lovage, parsley, inula, 
echinacea, angelica, burdock, and chicory no crystals of any kind occur. Rook hairs occur in cross-sections of sarsaparilla root and false unicorn, but with these exceptions: root hairs do not occur on roots, because the younger part of the root with root hairs is not removed from the soil when the drug is collected. In sarsaparilla root there are several layers of hypodermal cells; in most roots there are no hypodermal cells. In the non-woody roots or the roots of herbs the parenchyma cells form the greater part of the tissues of the root. In ruellia root are stone cells; in spigelia root and many other roots there are no stone cells. In ruellia root are bast fibres; in spigelia, gentian, ipecac, chicory, dandelion, symphytum, and lovage no bast fibres occur. In all the woody roots there is a periderm consisting of typical cork cells, as in black haw; or stone cells, as in asclepias; or of a mixture of lifeless parenchyma, medullary rays: etc., as in Oregon grape root.

Woody roots have a phellogen layer which is absent in the non-woody roots.

The numbers of layers of cortical parenchyma differ in the same root according to its age, but for a given root there is a normal variation.

The number of layers of cortical parenchyma in proportion to other cells is less in woody roots.

In woody roots there is no endodermis. The cambium in these cases shows clearly between the phloem and the xylem part of the fibro-vascular bundle.

In woody roots the wood fibres are well developed and form a large part of the root, and the medullary rays have pitted side and end walls.

The description given above of ruellia root is not typical of all roots, but the structure represents the greater number of the elements that it is possible to find in a root. In many roots, for instance, there are no stone cells, in others no epidermis and no endodermis. In asclepias, aconite, and calumba stone cells occur. In symphytum, chicory, dandelion, burdock, elecampane, pyrethrum, gentian, and senega no stone cells occur. In aconite, althea, asclepias, belladonna, bryonia, columba, ipecac, jalap, krameria, sarsaparilla, scamony, stillingea, and rumex are characteristic starch grains. Symphytum, chicory, dande- 
lion, burdock, elecampane, and pyrethrum contain inulin, but no starch. In saponaria, gentian, and senega neither starch nor inulin occurs.

When studying roots the nature of the epidermis or the periderm must be considered, as also the number of layers of cortical parenchyma; the occurrence, distribution, and amount of stone cells when present; the presence or absence of the endodermis; the occurrence and-structure of bast fibres when present; the nature of the cambium cells; the width and structure of the medullary rays, the size of the wood fibres and wood parenchyma, and the nature of the cell contents and the arrangement of the fibro-vascular bundle. 


\section{CHAPTER II}

\section{STEMS}

When studying stems it should first be determined whether they were derived from monocotyledonous or dicotyledonous plants. This fact is ascertained by determining the type of the fibro-vascular bundle. See Chapter XI. The next fact to determine is whether the stem is from an herb or from a woody plant. This fact is readily determined because herbaceous stems have a true epidermis, masses of collenchyma at the angles of the stem. The cortical cells contain chlorophyll, and the pith is very large. Woody stems have a corky layer, a phellogen layer, and the pith is very small except in the very young woody stems.

Having determined these facts, a study should be made of the arrangement, form, structure, color, and the cell contents of the different cells in order to determine the species of plant from which the stem was obtained.

\section{HERBACEOUS STEMS}

The great variation in the structure of herbaceous stems is shown in the cross-sections of spigelia (Plate 95); in ruellia (Plate 96); in the charts of powdered genuine horehound, powdered spurious horehound, and in the chart of powdered insect flower stems.

\section{CROSS-SECTION SPIGELIA STEM}

Spigelia stem (Plate 95) has the following characteristic structure:

Epidermis. The epidermal cells are papillate.

Cortex. The cortical parenchyma cells consist of tangentially elongated cells which are oval in outline.

Phloem. The phloem consists of sieve cells, phloem parenchyma, and of bast fibres. 


\section{PLATE 95}

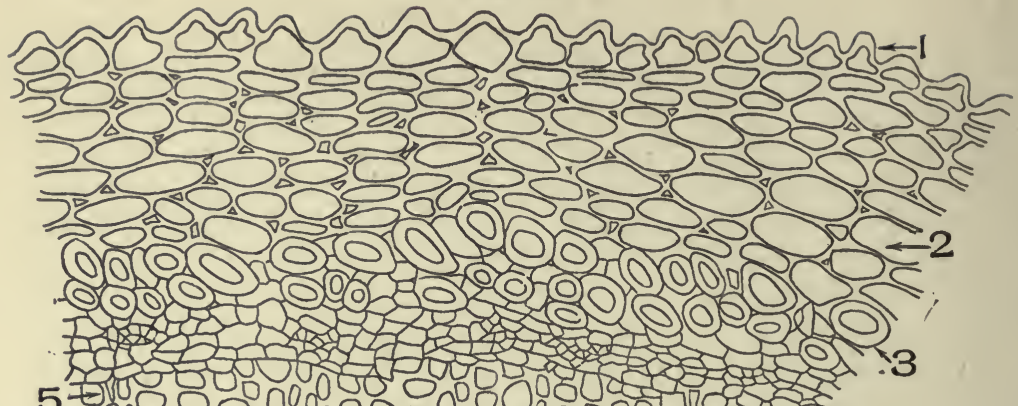

5 t)

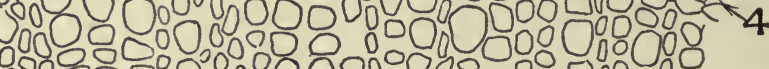

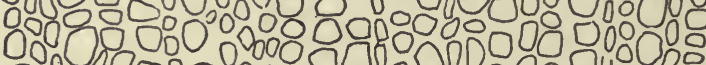

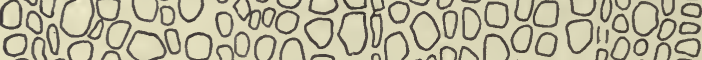

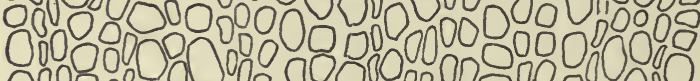

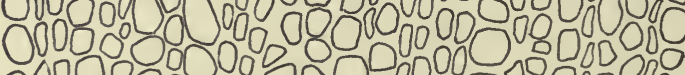

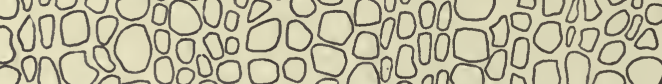

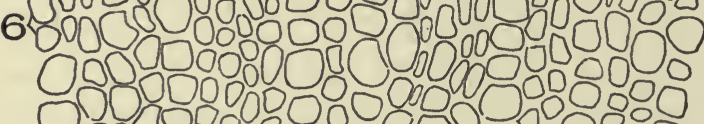

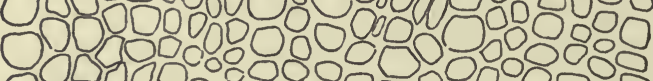

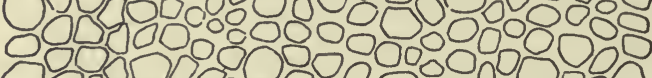
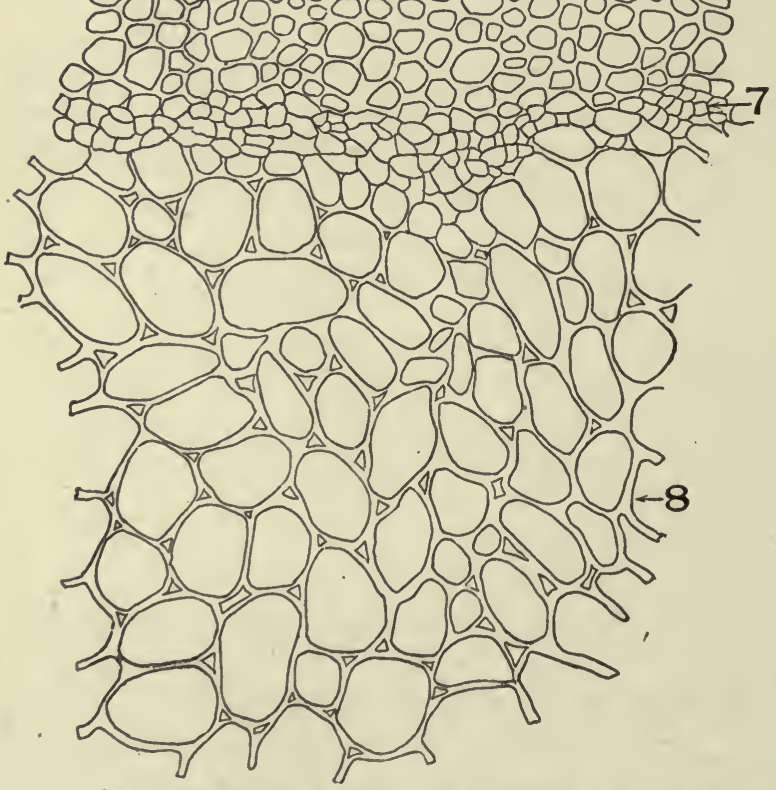

Cross-Section of Stem of Spigelia marylandica, L.

I. Papillate epidermis.

2. Cortical parenchyma.

3. Bast stereome.
4. Phloem.

5. Cambium

6. Xylem.
7. Inner phloem.

8. Pith. 
The sieve cells are small, and with thin, white, angled walls.

The phloem parenchyma resembles the sieve cells, but they are larger.

The bast fibres are rounded in outline and the walls are thick, white, non-porous, and non-striated.

Cambium. The cambium cells are rectangular in shape or the walls are collapsed and the cells indistinct.

Xylem. The xylem contains vessels, wood parenchyma, medullary rays. The vessels are small and angled, the walls are thick and white.

Wood parenchyma. The cells are variable in size and shape, and the walls are thick. The medullary ray cells are small, narrow, and tangentially elongated.

Internal Phloem. External to the pith parenchyma are isolated groups of internal phloem consisting of sieve cells.

Pith Parenchyma. The pith parenchyma cells are oval in form and irregularly placed. The cells contain small, simple starch grains.

\section{RUELLIA STEM}

The cross-section of ruellia stem (Plate 96) is as follows:

Epidermis. The epidermal cells are variable in shape and very large. There are no cell contents.

Cortex. The cortex consists of collenchyma and parenchyma cells and stone cells.

The collenchyma cells have very small, angled cavities and very thick walls. These cells make up the greater part of the cortex.

The cortical parenchyma cells are variable in size and shape. The stone cells occur singly or in groups. The walls are thick, white, porous, and striated, and the central cavity is frequently quite large.

Phloem. The phloem contains sieve cells, phloem parenchyma, and bast fibres.

The sieve cells have thin, white, angled walls.

The phloem parenchyma cells are frequently tangentially elongated, otherwise they resemble the sieve cells.

The bast fibres occur alone or in groups. The walls are thick, white and porous. 


\section{PLATE 96}

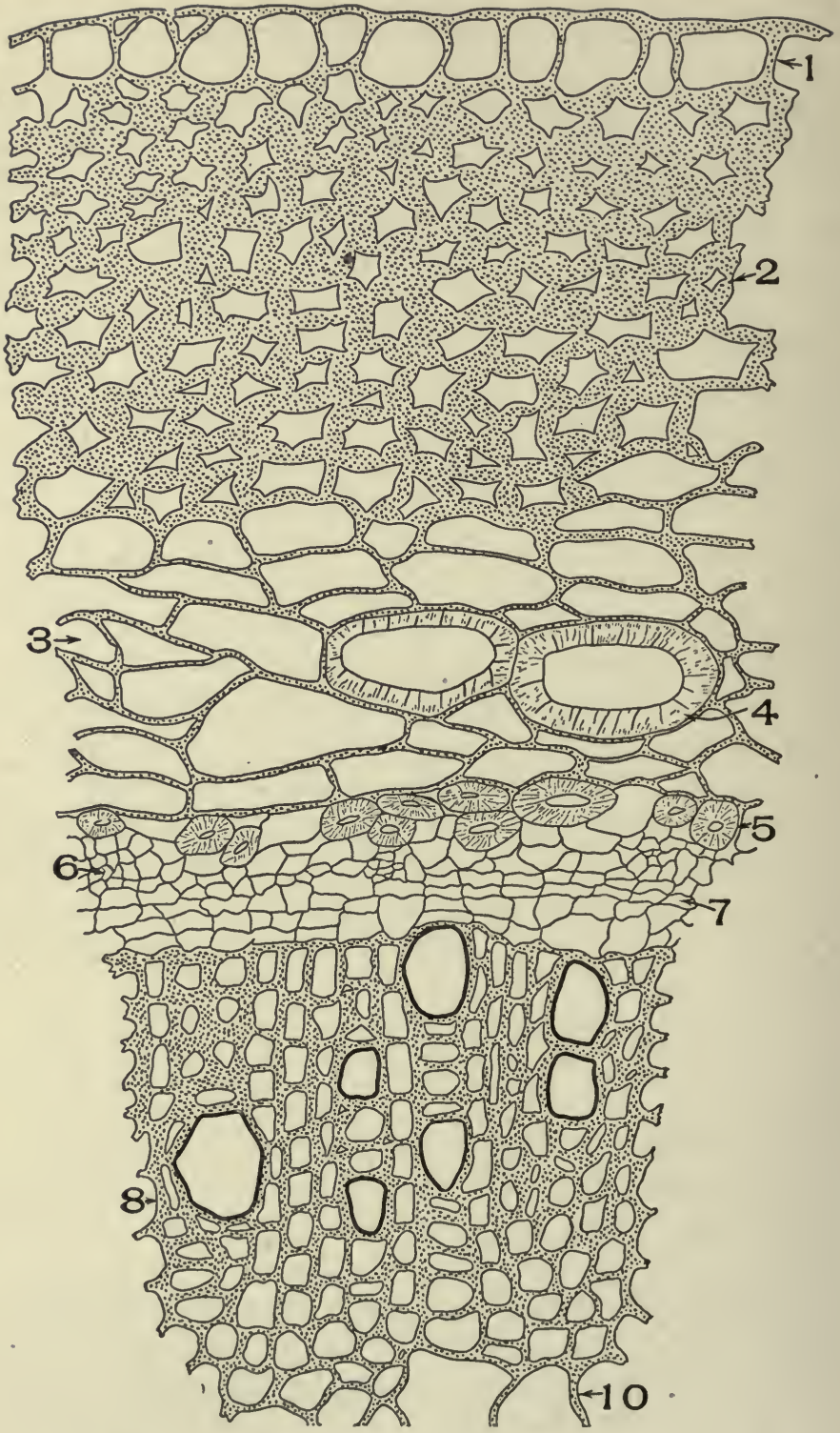

Cross-Section of Stem of Ruellia ciliosa, Pursh.

I. Epidermis. 2. Collenchyma. 3. Parenchyma. 4. Sclerids. 5. Bast fibres. 6. Phloem. 7. Cambium cells. 8. Xylem. 10. Pith parenchyma. 
Cambium. The cambium cells are rectangular in shape and the walls are thin.

Xylem. The xylem contains vessels, wood parenchyma, and medullary rays.

The vessels are large; the walls are thick, white, and angled.

The wood parenchyma cells are variable in size and shape and the walls are angled.

The medullary ray cells are radially elongated and rectangular in shape.

Pith Parenchyma. The pith parenchyma cells are large and rounded in shape.

\section{POWDERED HOREHOUND}

The structure of powdered horehound is shown in Chart 97. The epidermal cells of the leaf (I) are wavy in outline, the guard cells are elliptical, the stoma lens-shaped, the epidermis often showing hairy outgrowth as in the illustration. The epidermal cells of the petals (2) have irregularly thickened beaded walls. The non-glandular hairs from the calyx (3); the long, thinwalled, multicellular non-glandular twisted hairs (4) from the leaves and stems; long, thin-walled, unicellular hairs (5) from the tube of the corolla; the glandular hairs (6) with a one-celled stalk and with two secreting cells divided by vertical walls; the eight-celled glandular hair (7) as seen in surface and side view; the spiral and reticulated conducting cells (8); the thick, whitewalled fibres from the stem (9); the pollen grains (Io) with nearly smooth walls.

The diagnostic elements of the U. S. P. horehound are the long, twisted, multicellular hairs (4), the glandular hairs (7), and the pollen grains (ro).

\section{POWDERED SPURIOUS HOREHOUND}

Marrubium perigrinum, which is a related species of horehound and which is a common adulterant of horehound, has the following structure (Plate 98):

The wavy leaf epidermis (I) with stoma; the beaded wall petal epidermis (2); the non-glandular, multicellular branched hairs (3) from the stem leaves or flowers; the broken pieces and branches of the compound hairs (4) scattered throughout the 


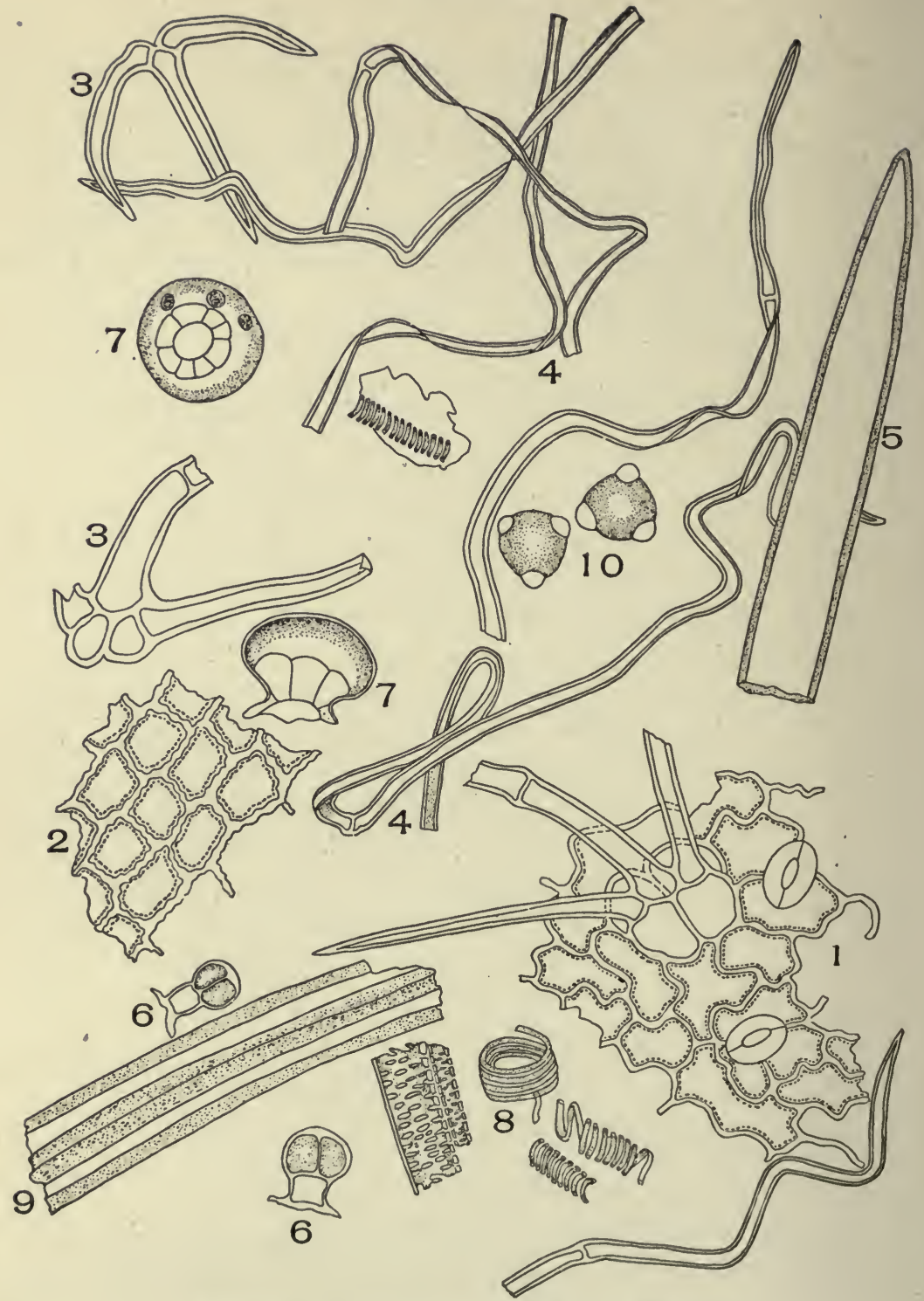

POWDEREd HoREHOUNd (Marrubium vulgare, L).

I. Epidermis of leaf showing the wavy epidermal cells, stoma, and a clustered hair. 2. Surface view of the petal epidermis. 3. Non-glandular hair from the calyx or corolla. 4. Long, thin-walled, twisted, non-glandular hairs from the leaves and stem. 5. Unicellular non-glandular hair from the tube of the corolla. 6. Glandular hairs with a one-celled stalk and with two secreting cells divided by vertical walls. 7. Surface and side view of the eight-celled glandular hairs. 8. Conducting cells. 9. Fibres from the stem. I0. Pollen grains. 


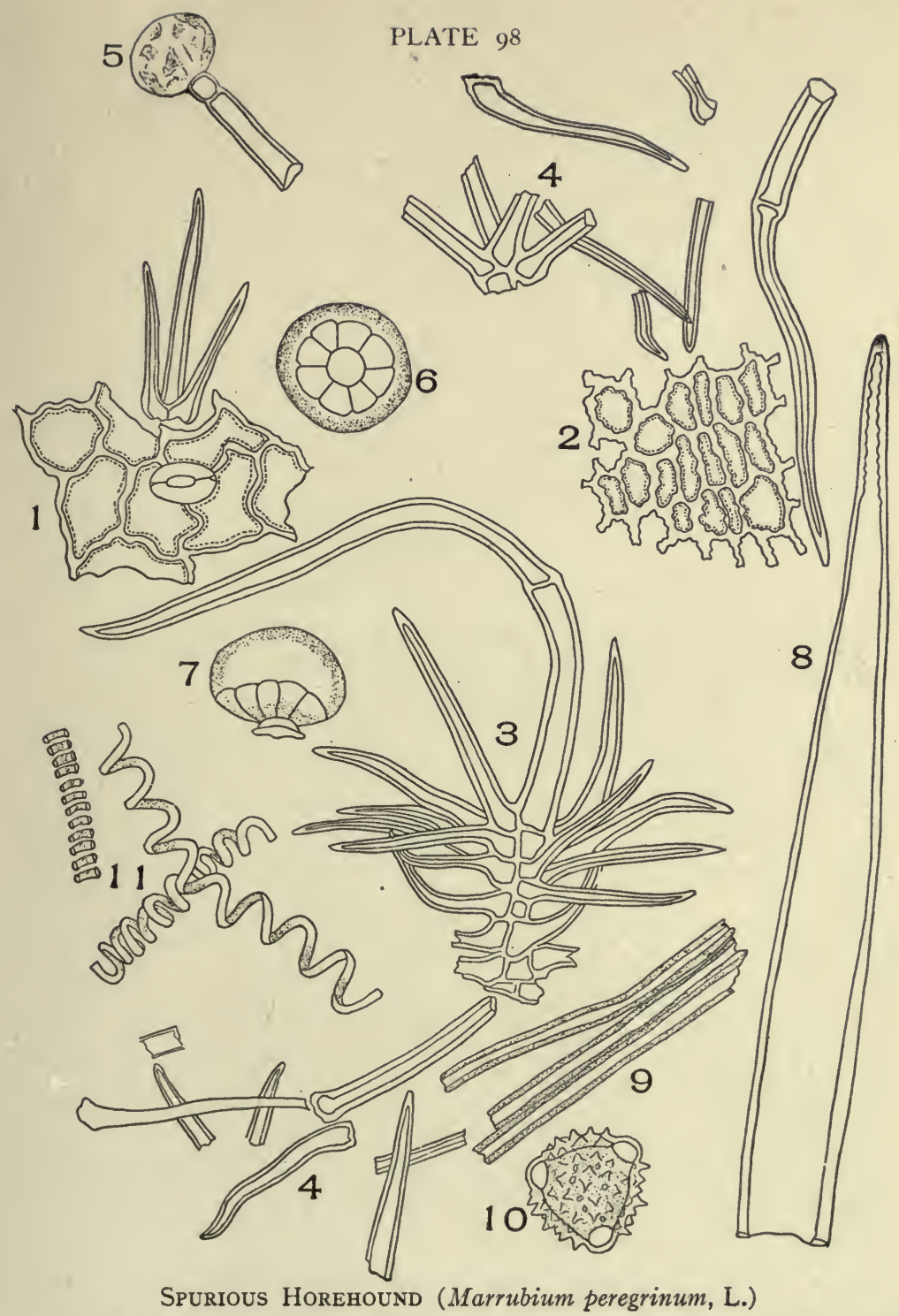

I. Surface view of the leaf epidermis. 2. View of the petal epidermis. 3. Non-glandular multicellular branched hair from the stem, leaves, or flowers with a few of the lower branches broken. 4. Broken pieces and branches from the compound hairs scattered throughout the field. 5. Unicellular glandular hair with a two-celled stalk. 6. Under-surface view of an eight-celled glandular hair. 7. Side view of eight-celled glandular hair. 8. Long, pointed, unicellular, non-glandular hair from the corolla, the wall irregularly thickened near the apex. 9. Fibres. IO. Pollen grains. Ir. Conducting cells of leaf. 


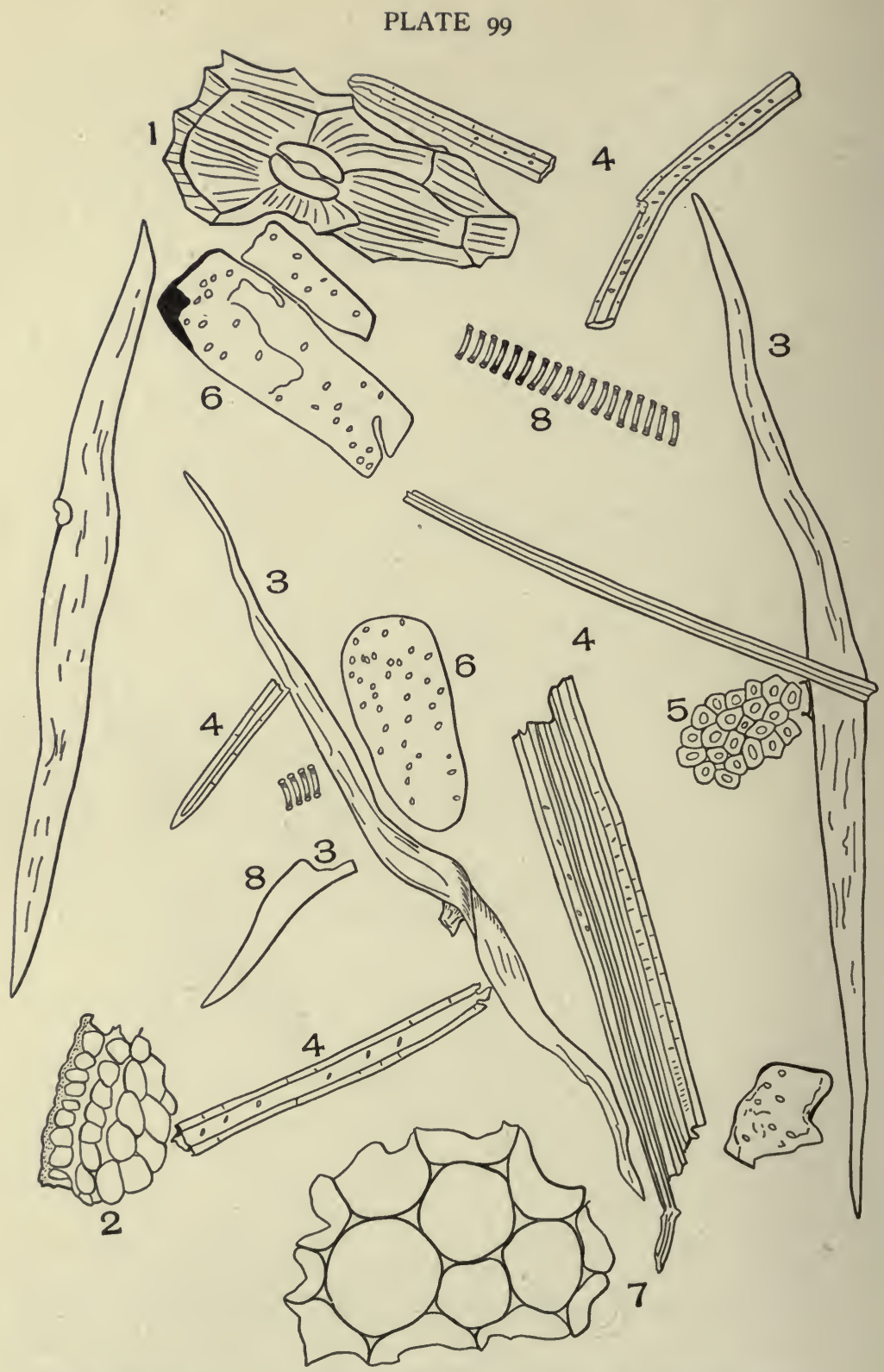

Powdered Insect Flower Stems (Chrysanthemum cinerariifolium, [Trev.], Vis.)

I. Surface view of epidermis.

2. Cross-section of epidermis.

3. Hairs.

4. Fibres.
5. Cross-section of fibres.

6. Longitudinal view of pith parenchyma.

7. Cross-section of pith parenchyma.

8. Conducting cells. 
field; the glandular hairs (5) with a two-celled stalk; the eightcelled glandular hair (7) seen in surface view and a side view (8) of a similar hair; the long, pointed, unicellular non-glandular hair from the tube of the corolla, the wall irregularly thickened near the apex; the fibres (9) from the stem; the pollen grains (Io) with prominent centrifugal projections; the conducting cells.

The diagnostic elements of marrubium perigrinum are the multicellular branched hairs (3) which occur on all parts of the plant, usually much broken in the powder, with walls many times thicker than the walls of the hairs found in U. S. P. horehound; the pollen grains (Io) with centrifugal projections and the stalked glandular hairs (5).

\section{INSECT FLOWER STEMS}

Insect flower stems are the chief adulterant of insect flowers. Until the passage of the insecticide law, it was a common practice to sell (for insect powder) a mixture of powdered stems and flowers. Since the passage of the law, the presence of the stems in a powder is supposed to be declared on the label. In spite of the penalties attached, their presence in a powder is frequently not declared, as evidenced by a microscopical examination of the insect powders obtained in the open market.

The structure of powdered insect flower stems (Chart 99) is as follows:

The epidermal cells of the stems are prominently marked with stoma and angled, striated wall cells (Fig. I). On crosssection (Fig. 2) the stem is seen to be made up of epidermal cells with thick outer and thin side walls (Fig. 2). The T-shaped hairs (Fig. 3) are longer than those found on any other part of the plant. The fibres (Fig. 4) are the most characteristic part of the powder. They are elongated, and the walls are white and slightly porous and of nearly uniform thickness. They occur free in the field or in groups of two or more. The cross-section view of these fibres is shown in Fig. 5. The pith parenchyma (Fig. 6) is abundant and is composed of thick, porous-walled cells. On cross-section the cells are rounded and are separated by intercellular spaces. The conducting cells (Fig. 8) vary from spiral to reticulate. 


\section{CHAPTER III}

\section{WOODY S'TEMS}

\section{BUCHU STEM}

The cross-section of a buchu stem (Plate C), r.6 millimeters in diameter, shows a few of the epidermal cells modified into thick-walled, roughish, unicellular trichomes (I). The remaining epidermal cells have a thick, wavy outer wall (2). Beneath the epidermis are several rows of cortical parenchyma cells (3) which extend to the bast bundles and in which are found the secretory cavities with the thin-walled secretory cells (4). 'The bast fibres (5) occur in continuous bands, varying greatly in size; the walls are whitish and of variable thickness. Inside the bast fibres, the small irregular sieve cells (6) occur in groups, surrounded by the phloem parenchyma (8). The radially elongated cells of the medullary rays (7) extend outward from the xylem, increasing in number in the outer portions of the wood, and extending nearly to the bast fibres. No distinct cambium layer is visible. The conducting cells (9) occur throughout the xylem surrounded by the wood fibres and wood parenchyma (Io). The latter is not very abundant in buchu. The medullary rays border on the conducting cells and extend outward to the phloem. The pith parenchyma cells are nearly circular in outline and often show a perforated end wall when a cell happens to be cut just above or below that point.

\section{MATURE BUCHU STEM}

In Plate IOI-A is shown the cork formation or secondary growth as seen in the older, larger buchu stems. The wavy epidermis (I), which is the primary epidermis and which has disappeared on many portions of the stem, has thin side walls and dark cell contents (2). Next to the epidermal cells occur several rows of peculiarly arched cork cells with thick, white outer walls (3) and reddish-brown cell contents (4). The cork 


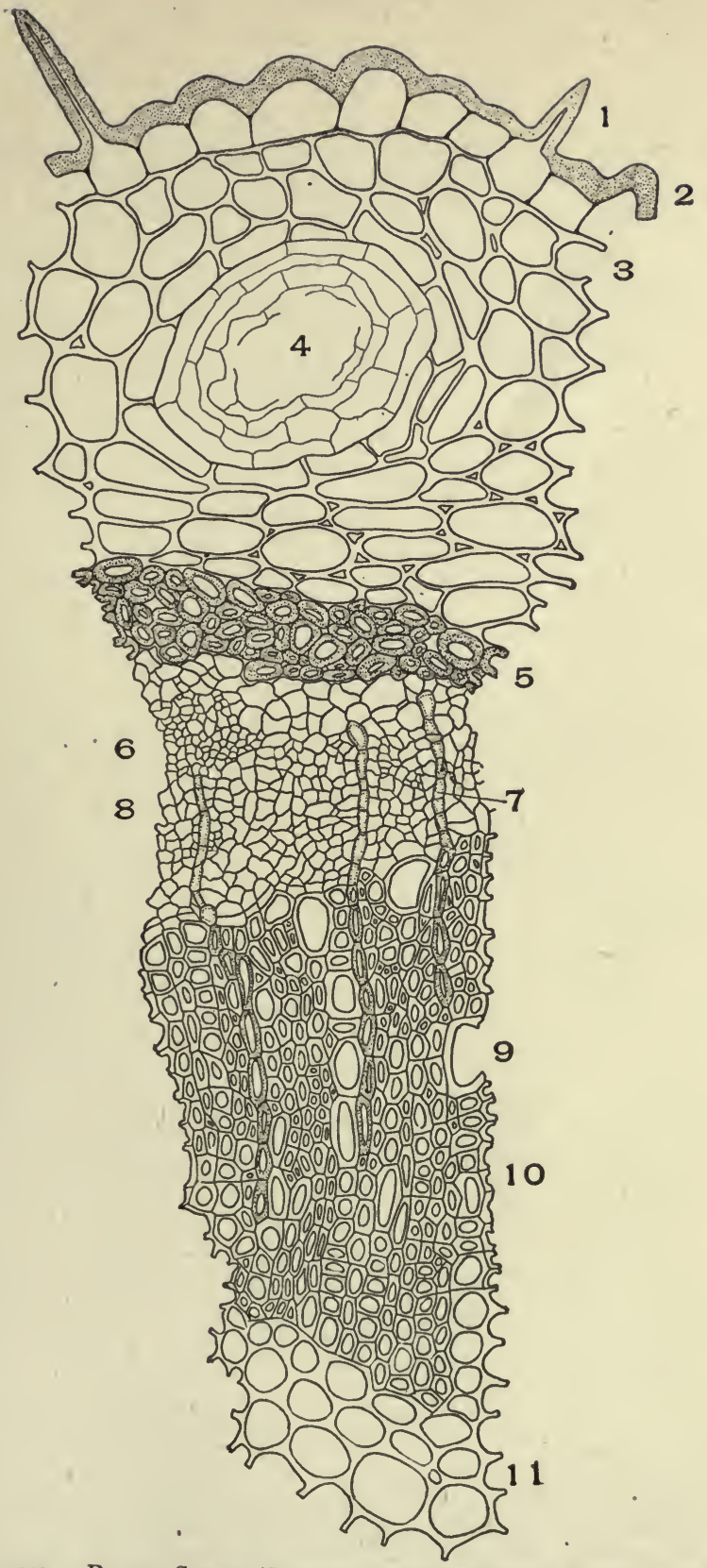

Cross-Section of Buchu Stems (Barosma betulina [Berg.], Barth. and Wendl.)

I. Hairs. 2. Wavy epidermis. 3. Cortical parenchyma. 4. Secretion cells and cavity. 5. Group of bast fibres. 6. Sieve cells. 7. Medullary rays. 8. Phloem parenchyma. 9. Vessels. Io. Wood fibres, and wood parenchyma. II. Pith parenchyma. 


\section{PLATE IOI}
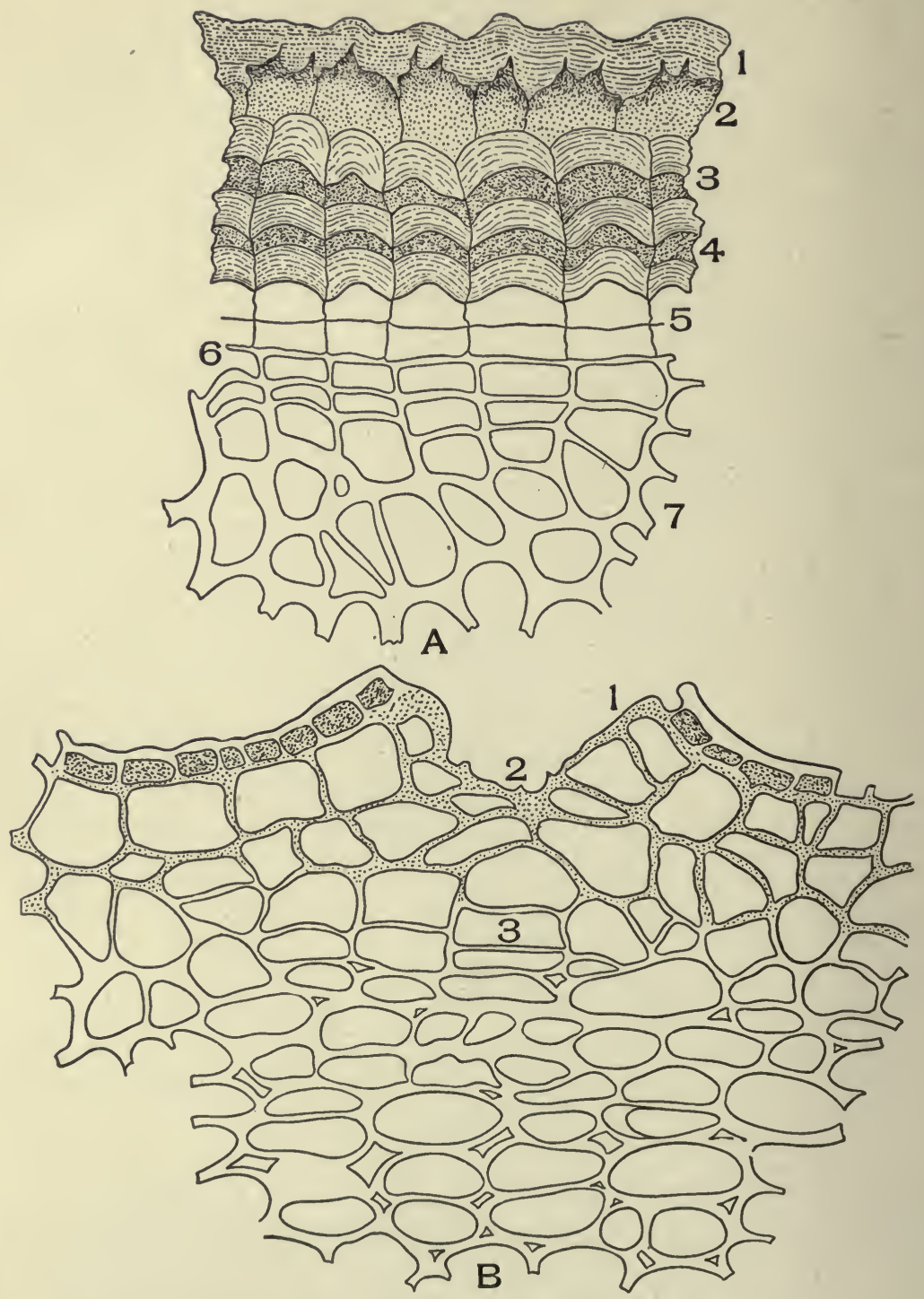

A. Cross-section of buchu stem (Barosma betulina [Berg.], Barth. and Wendl.). I, Outer wall of epidermis; 2, Cell cavity of epidermal cell; 3, Wall of cork cell; 4, Cavity of cork cell; 5, Phellogen layer; 6, Divided phellogen cell changing into a cortical parenchyma cell; 7 , Cortical parenchyma cell.

B. Cross-section of leptandra rhizome (Leptandra virginica [L.], Nutt.). I, Parenchyma cells undergoing change in the composition of their walls; 2, A break in the epidermal tissue; 3, Parenchyma cells undergoing division. 
cambium (5) is typical in form, and it has formed one or two layers of phelloderm cells (6) which have the same form as the cambium cells but with thicker walls. Next to the phelloderm occur the cortical parenchyma cells. The remaining structure of the mature stem is identical with that of Fig. 2.

\section{POWDERED BUCHU STEM}

Powdered buchu stem (Plate IO2) has many striking features which make it easy of identification when mixed with buchu leaves. A few unicellular, rough, thick, white-walled trichomes (I) occur distributed throughout the field. They are straight or slightly curved and vary in length from 40 to Ioo microns; in thickness at the bast they measure from ro to 22 microns. The central cavity varies greatly, and in some trichomes seems to have disappeared entirely. The epidermal cells (2) are very characteristic, occurring singly or in groups of two or more. The cells from the older stems often appear reddish brown by transmitted light, while the epidermal cells from the younger stems appear whitish opaque (porcelain-like). They are usually six-sided and angular in outline. The cortical parenchyma cells (3) on transverse view have a rounded cell cavity and intercellular spaces between the walls. The double walls vary in thickness, the greatest thickness being about 9 microns. The parenchyma cells (3) on longitudinal view show square ends and often contain sphæro-crystalline masses of hesperidin. The thin-walled sieve cells and the surrounding cells are scarcely ever seen in the powder. The white-walled pointed stereomes (4) are a characteristic feature of the powder; they vary greatly in length, in ciiameter and in the thickness of their walls. In a number eighty powder the fibres are mostly broken. The greatest length of the unbroken fibres is 1.25 microns. The thickest wall measured 5 microns and the greatest observed width was 25 microns. The spiral reticulate and scalariform thickened conducting cells oçcur scattered throughout the powder. The reticulate and scalariform cells usually occur with wood fibres. It is an interesting fact that the spiral thickening in conducting cells is usually separate from the side wall and nearly always appears as indicated at 5. An occasional rosette crystal of calcium oxalate (6) is seen in the field. The wood 
PLATE 102

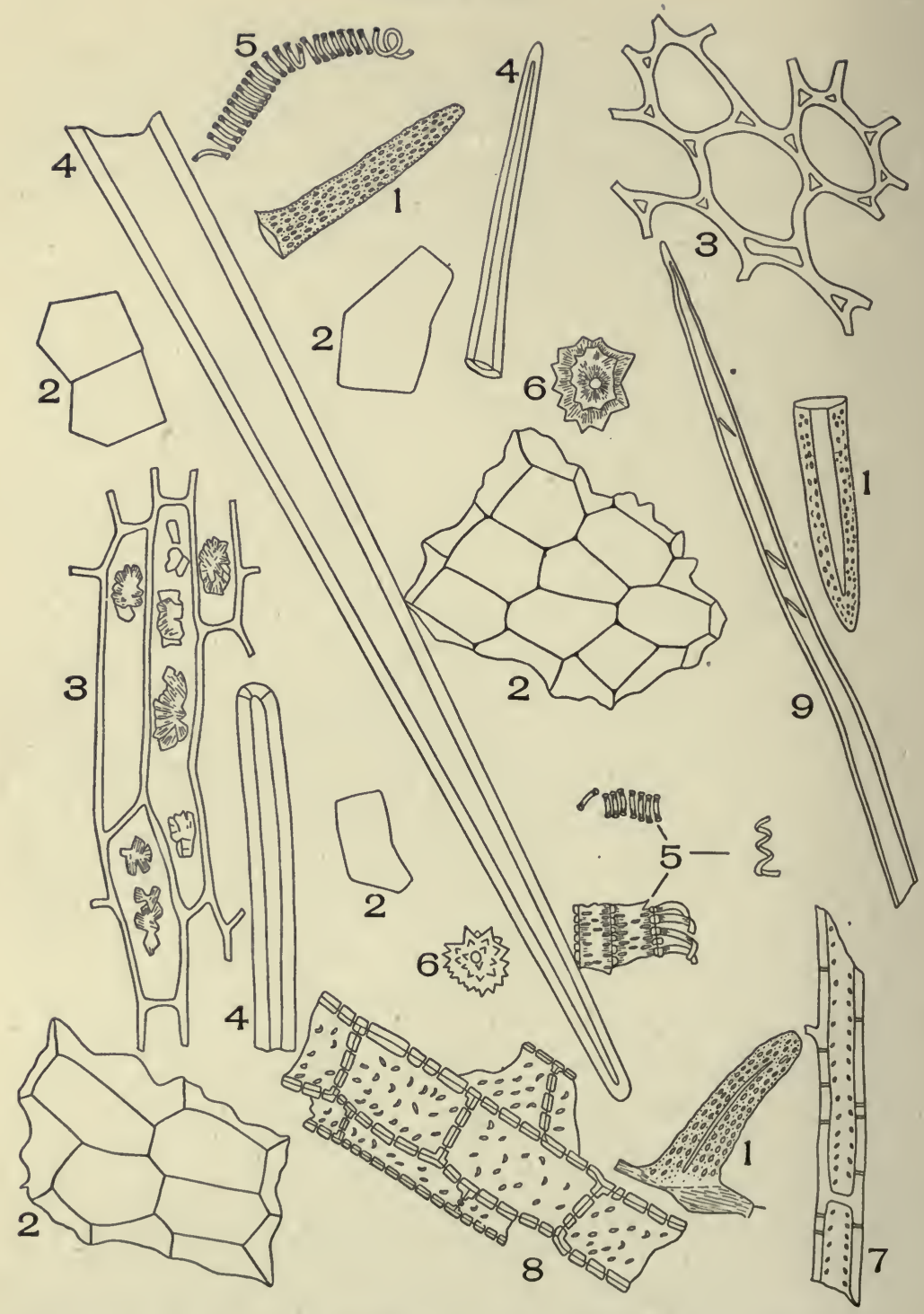

Powdered Buchu Stems (Barosma betulina (Berg.], Barth. and Wendl.).

I. Hairs. 2. Epidermal cells, the larger pieces reddish-brown; the smaller aggregations white. 3. Transverse cortical parenchyma. 3'. Longitudinal cortical parenchyma with sphæro crystalline masses of hesperidin. 4. Bast fibres. 5. Spiral, sclariform, and reticulate vessels. 6. Rosette crystals of calcium oxalate. 7. Wood parenchyma. 8. Pith parenchyma with porous side and end walls. 9. Wood fibres. 
parenchyma (7), which makes up a very small percentage of the xylem, is not readily found in the powder. The pith parenchyma cells (8) have thick, porous side walls and perforated side walls. The wood fibres (9) usually occur in masses surrounding the conducting cells; when occurring singly, the oblique pores readily distinguish them from the bast fibres.

The diagnostic elements of powdered buchu stems are:

First, trichomes; secondly, reddish-brown and white-angled epidermal cells; thirdly, the long, white bast fibres. 


\section{CHAPTER IV}

\section{BARKS}

Barks are all obtained from dicotyledonous plants. In studying barks there should be ascertained the thickness, arrangement, form, structure, color, and cell contents of the cells occurring in the outer, middle, and inner barks.

The outer bark includes the cork cells and the phellogen layer. The middle bark includes all the cells occurring between the phellogen layer and the beginning of the medullary rays. The inner bark includes the medullary ray cells and all cells associated with them. The plan of structure of all barks is similar, but in each species of plant the structure of the bark is uniform and characteristic for the species.

A great number of drugs consist of the bark of woody plants; for this reason the bark is considered in a separate chapter from the stem.

\section{WHITE PINE BARK}

The cross-section of white pine bark (Plate I03) has the following structure:

Outer Bark. The periderm consists of several layers of reddish-brown cork cells (I) which are narrow, elongated, and with thin walls.

Middle Bark. The cells forming the middle bark are parenchyma and secretion cells.

The parenchyma cells vary greatly in size, form, and thickness of the walls. The cells beneath the cork cells and around the secretion cells are tangentially elongated and oval in shape, while the other parenchyma cells are more irregular in shape.

The secretion cells are arranged around the schizogenous secretion cavities. The cells are tangentially elongated, and the walls, which are slightly papillate, are white.

Inner Bark. The cells forming the inner bark are medullary rays, parenchyma, sieve cells, and storage cavities. 

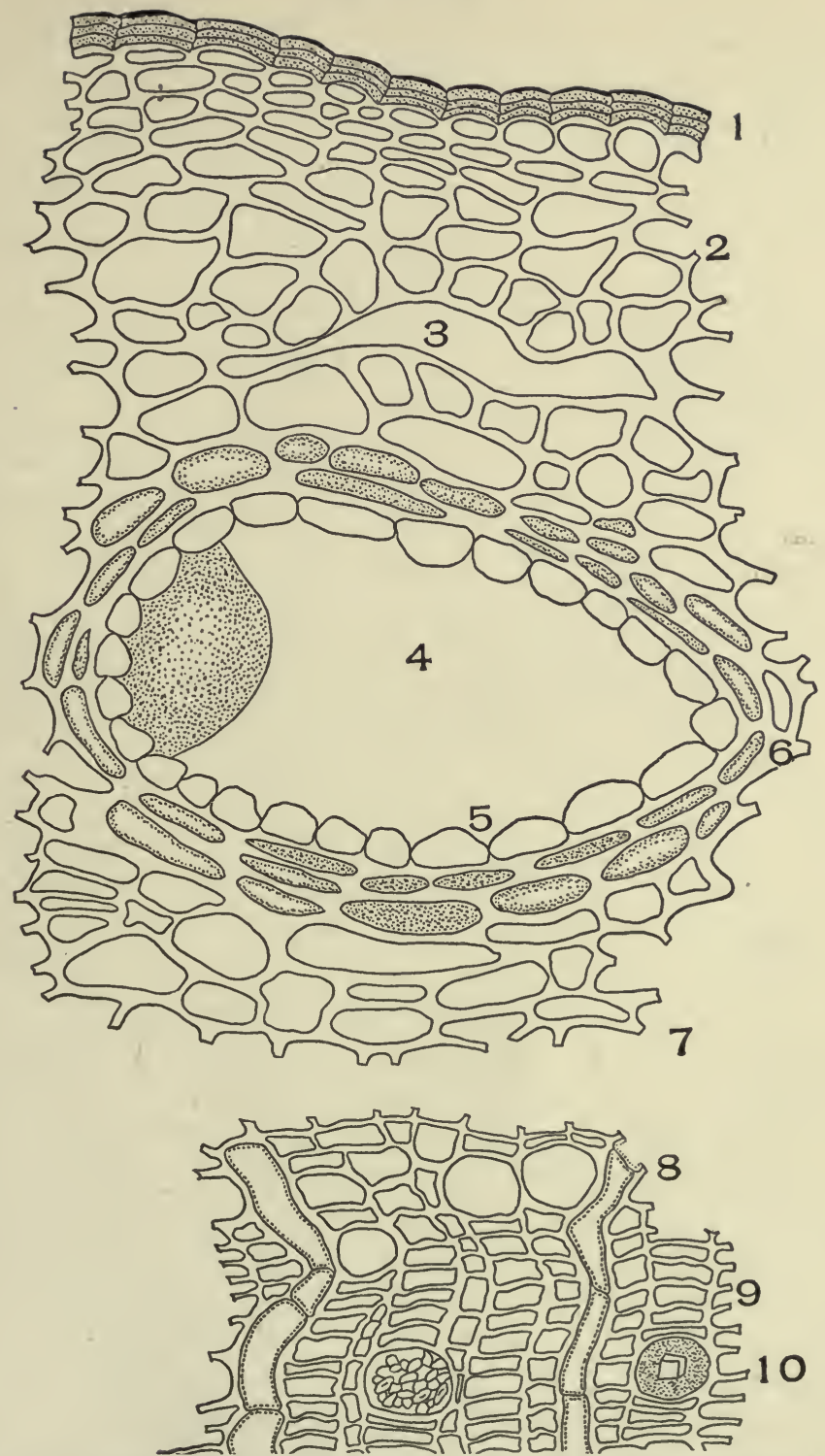

Cross-Section of Unrossed White Pine Bark (Pinus strobus, L.)

I. Cork cells of the epidermis. 2. Parenchyma cells filled with chlorophyl. 3. Intercellular space. 4. Secretion cavity with resin. 5. Secretion cells.

6. One or more circles of parenchyma filled with chlorophyl. 7. Parenchyma.

8. Meduilary rays. 9. Sieve cells. Io. Storage cavities. 
The medullary rays form wavy lines. The medullary ray cells are radially elongated, rectangular in shape, and they contain granular cell contents. The sieve cells are either square or rectangular in shape. The walls are thin and white. The storage cavities are either filled with starch or with prisms and tannin.

\section{POWDERED WHITE PINE BARK}

White pine bark (Plate IO4) when powdered shows the following characteristic elements:

The microscopic structure of a powdered white pine is as follows: The epidermis (I) consists of reddish-brown masses, irregular in outline. The outer parenchyma cells are of a brightgreen color, owing to the presence of chlorophyll. (The above elements are not usually found in the rossed bark.) The parenchyma (3) with starch usually occurs in longitudinal sections accompanied with sieve cells. Often the tissue separates transversely, showing the medullary rays (4) with their granular cell contents (9) and the inner parenchyma cells filled with starch and the surrounding sieve cells.

The crystals are nearly perfect cubes and occur singly (5) or in groups (6). On the longitudinal section of the bark the crystals occur in parenchyma cells surrounded by a reddish cell content and form parallel rows which are very characteristic. The resin occurs either as white, angled fragments (7) in a water mount, or as globular mass (8) or as reddish-brown pieces (I0). The starch is very abundant and is distributed through the field. The diagnostic grain is lens-shaped, with a cleft hilum, which is nearly straight, or slightly curved, and runs parallel to the long diameter of the grain. The addition of ferric chlorid T. S. will show the presence of tannin by forming a dark coloration. The identification of the starch is facilitated by the addition of a weak Lugol's solution, which.imparts a blue coloration to the starch grain.

The form, amount, and distribution of the cells composing the bark differ greatly in different plants.

In cramp bark the cork and phellogen cells are very large, while in cascara sagrada the phellogen and the cork cells are very small. 
PLATE 104

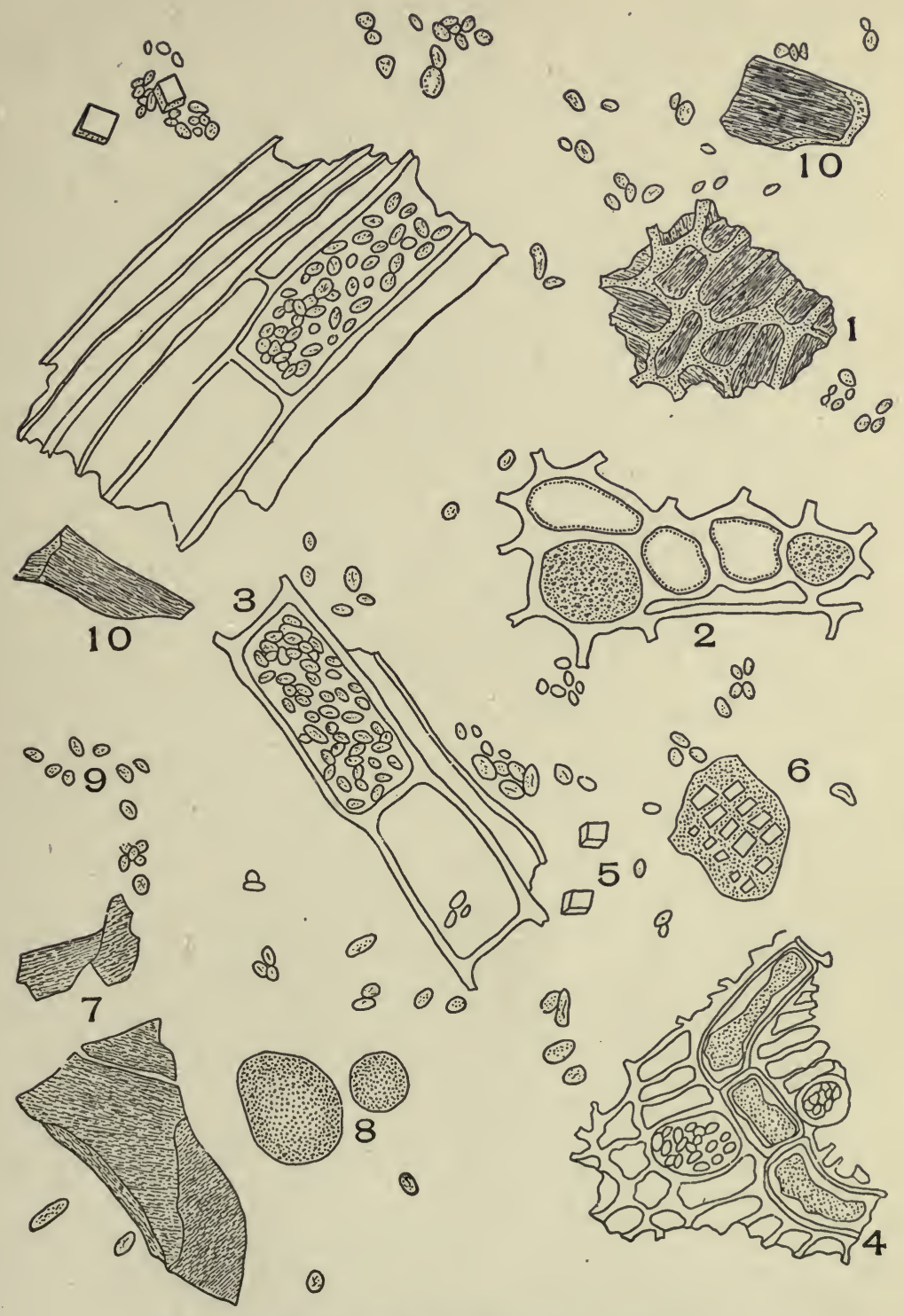

Powdered White Pine Bark (Pinus strobus, L.)

I. Epidermis. 2. Parenchyma cells. 3. Parenchyma with starch. 4. Medullary rays. 5. Solitary crystals. 6. Solitary crystals and tannin. 7,8 and 10. Resin masses. 9. Starch. 
In canella alba bark the periderm is composed of stonecell cork or stone cells arranged in superimposed rows, which form the outer layers of the bark.

In white oak and most barks from woody trees the periderm consists of lifeless parenchyma, medullary rays, sieve cells, bast fibres, and in some cases stone cells and of phellogen cells.

In young wild cherry, cascara sagrada, and frangula are several layers of tangentially elongated collenchyma cells with chlorophyll. In the older barks of the above and in many other barks no collenchyma cells occur.

In cramp bark and in tulip tree bark the outer layers of the cortical parenchyma cells are beaded. In most barks there is no beaded walled parenchyma. The outer layers of most cortical parenchyma cells are tangentially elongated while the inner parenchyma cells are mostly circular in outline,

In white oak, cascara sagrada and prickly ash are groups of stone cells; in the cinnamon barks are bands of stone cells; in cinchona bark are isolated stone cells. In cramp bark, mezerum, elm, and white pine bark no stone cells occur.

In frangula, cascara sagrada, cocillina, cinnamon, cinchona, sassafras, and wild cherry barks the bast fibres occur in groups. In frangula, cascara sagrada, and cocillina the bast fibres are surrounded by crystal cells with crystals.

In sassafras bark mucilage cells occur. In canella alba, white pine, and sassafras barks secretion cells occur; but in most barks no secretion cells occur.

In sassafras bark the medullary ray cells are nearly as broad as long; in cramp bark they are elongated and oval in shape. In cascara sagrada, as in most barks, the cells are longer than broad and rectangular in shape.

In cascara sagrada the sieve cells are very large; in granatum bark the sieve cells are very small.

In cassia cinnamon and in canella alba bark the walls of the sieve cells have collapsed, with the result that the sieve cells have become partly obliterated.

In witch-hazel, mountain maple, willow, and black walnut are found prisms; in cramp bark, black haw, wahoo, pomegranate, and cotton root bark are found rosette crystals; in 
the cinnamon barks are found raphides; in cinchona bark, micro-crystals.

In cocillina, frangula, cascara sagrada, white oak, poplar and Jamaica dogwood barks are found crystal-bearing fibres (Plates I9 and 20).

When studying barks we must consider the kind, structure, and amount of the periderm; the nature of the phellogen; the nature and amount of the cortical parenchyma; the occurrence, distribution, and amount of stone cells, when present; the occurrence and structure of the bast fibres; the presence or absence of secretion cells; the width, distribution, and structure of the medullary rays. 


\section{CHAPTER V}

\section{WOODS}

Quite a number of drugs consist of the wood of woody plants; such drugs are quassia, red saunders, white sandalwood, and guaiac.

When studying woods it is necessary to observe the cross, tangential, and radial sections. Such sections of quassia are shown in Plates 105, 106, and 107. When studying these sections it should be remembered that while the types of cells forming quassia wood are similar to the cells forming other woods, still their structure, arrangement, and amount will vary in a recognizable way in the different woods.

\section{CROSS-SECTION QUASSIA}

Plate I05 is a cross-section of quassia. It has the following structure:

Vessels. The vessels occur singly or in groups of two to eight cells. The cells are variable in size and shape. The walls are yellowish white and porous.

Medullary Rays. The medullary rays vary from one to five cells in width.

The medullary ray cells are radially elongated and the walls are strongly porous.

Wood Parenchyma. The wood parenchyma cells have thin, yellowish-white, angled walls.

Wood Fibres. The wood fibres have thick, yellowish-white, angled walls. These cells are smaller in diameter than the wood parenchyma cells.

\section{RADLAL SECTION QUASSIA}

The radial section of quassia (Plate I07) is as follows:

Vessels. The vessels appear as in the tangential section.

Medullary rays. The medullary rays vary from ten to 
PLATE 105

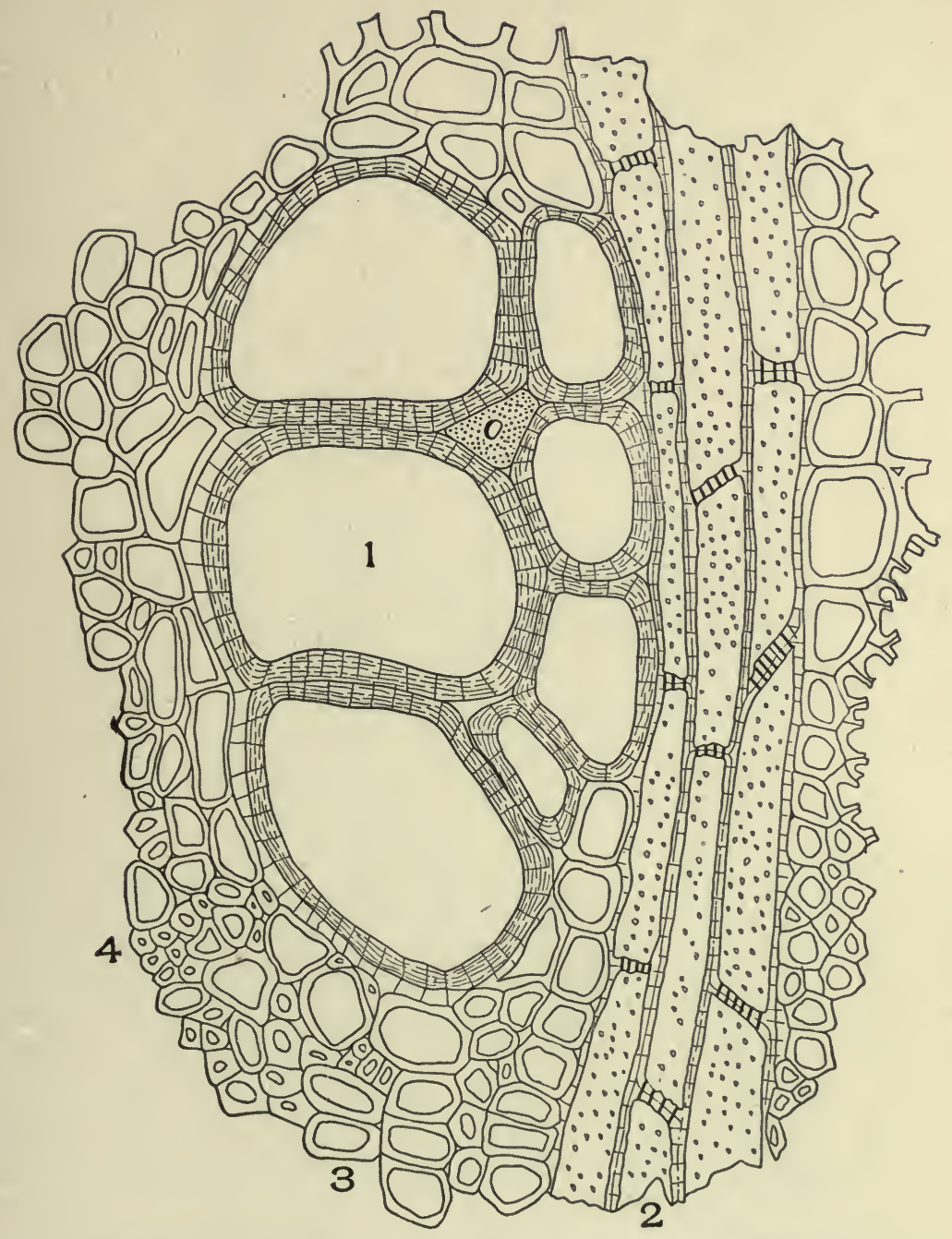

Cross-Section of Quassia Wood (Picrana excelsa [Sw.], Lindl.)

I. Vessels.

2. Medullary rays.

3. Wood parenchyma.

4. Wood fibres. 
PLATE 106

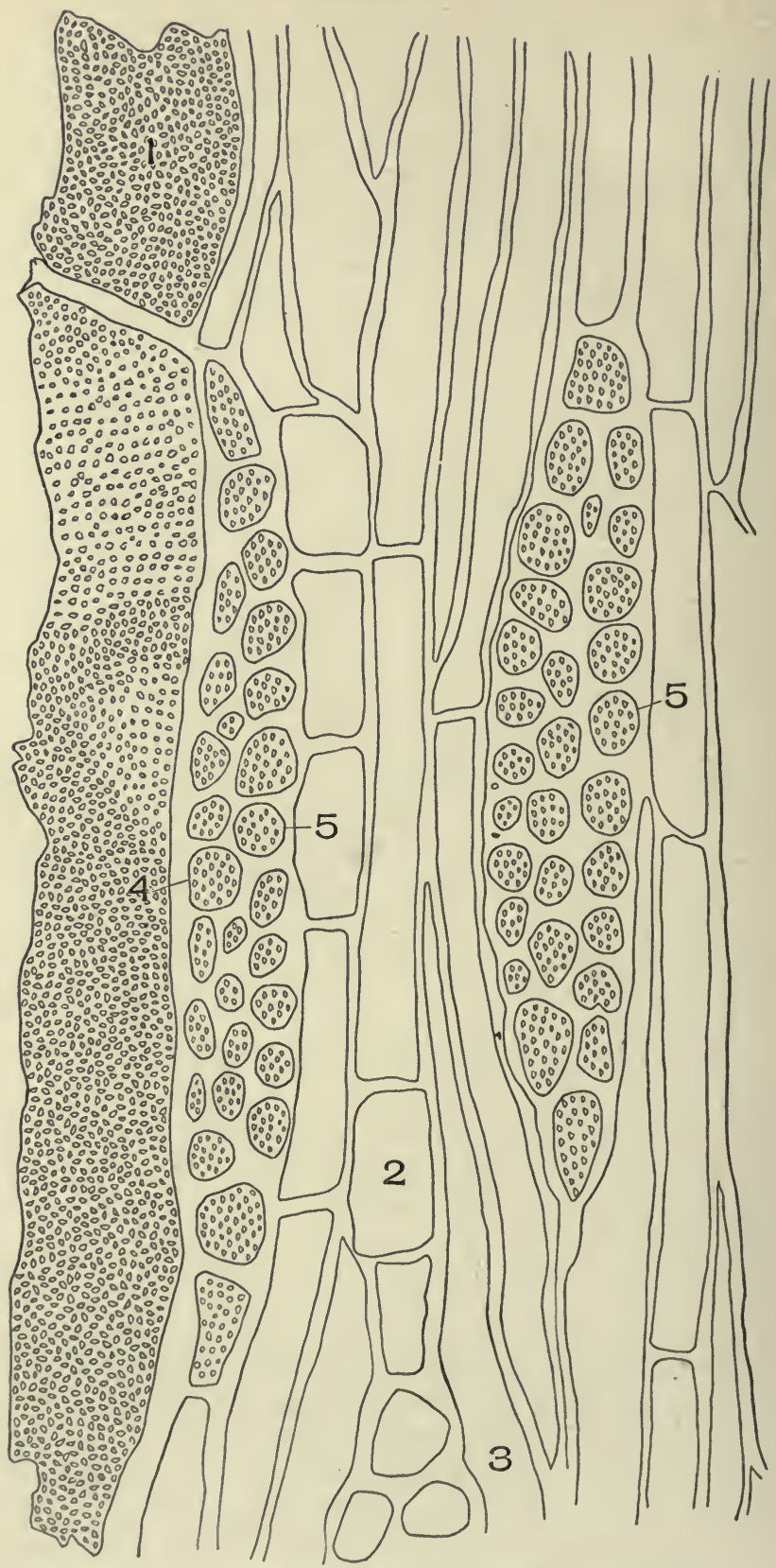

Tangential Section of Quassia Wood (Picrana excelsa [Sw.], Lindl.)

I. Vessel. 2. Wood parenchyma. 3. Wood fibre. 4. End wall of medullary ray cell. 5. Medullary ray bundle. 


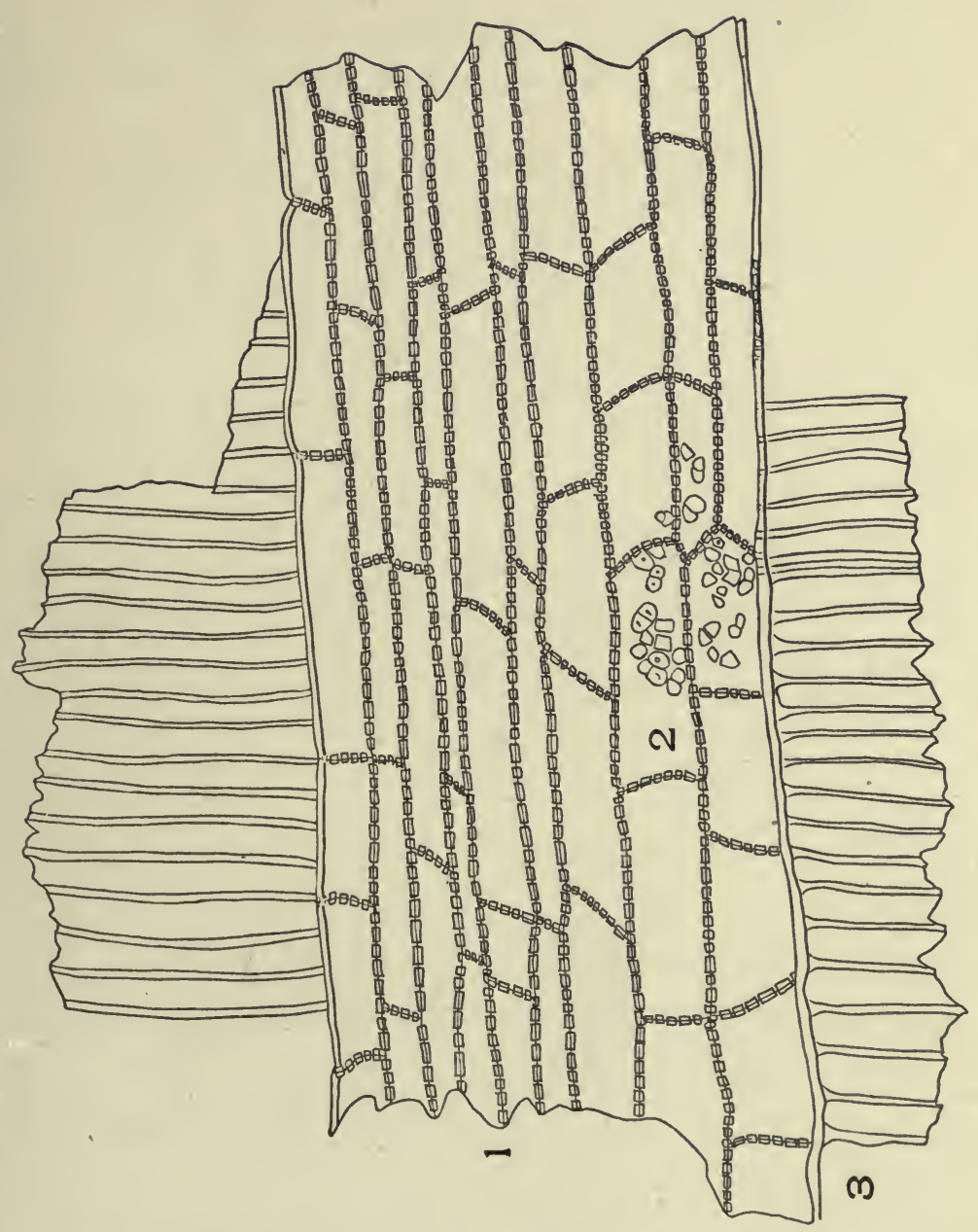

Radial Section of Quassia Wood (Picrcena excelsa [Sw.], Lindl.)

I. Showing the height and length of the medullary rays and cells.

2. Cells with starch.

3. Wood parenchyma and wood fibres. 
twenty cells in height according to the part of the medullary ray bundle cut across.

The medullary ray cells exhibit their height and length. The walls of the cells are yellowish white and strongly porous.

Wood Parenchyma. The wood parenchyma cells have yellowish, thin walls and blunt end walls.

Wood Fibres. The wood fibres have thick, yellowish-white walls, and the end of the cells are strongly tapering.

\section{TANGENTIAL SECTION QUASSIA}

The tangential section of quassia (Plate 106) shows the following structure:

Vessels. The vessels are very long and broad and the yellow walls are marked with clearly defined pits.

Medullary Rays. The tangential section shows the crosssection of the medullary ray bundle and the cross-section of the medullary ray cell.

The medullary ray bundle varies in width from one to five cells. The ends of the bundles are always one cell in width, while the central part of the bundle is frequently five cells in width.

The medullary ray cell varies in size, structure, and shape according to the part of the cell cut across. The cells cut across the centre show hollow spaces, but the cells cut just above or below the end wall show a strongly pitted surface. The cells forming the end of the bundle are larger than the cells forming the centre of the bundle.

Wood Parenchyma. The wood parenchyma cells are greatly elongated and the walls are thin and yellowish white. The ends of the cells are blunt.

Wood Fibres. The wood fibres are elongated, the walls are thick and the cells are strongly tapering.

In quassia, white sandalwood, red sandalwood, and guaiac wood are characteristic crystals.

In quassia the vesséls are finely pitted, yellowish, and distinct; in white sandalwood the vessels are coarsely and sparingly pitted and white translucent; in red saunders the vessels are coarsely pitted, bright red and distinct. 
When studying woods we must consider the width of the medullary rays, the structure and cell contents of the medullary ray cells; the structure, color, and cell contents of the wood parenchyma; also the wood fibres. 


\section{CHAPTER · VI}

\section{LEAVES}

Leaves collectively constitute the greatest manufacturing plant in the world. Most of the food, clothing, and medicine used by man is formed as a result of the work of the leaf. The cell contents, structure, and arrangement of the different cells of the leaf differ in a marked degree from the cell contents, structure, and arrangement of the cells in the other organs of the plant. This accounts for the presence of the large amount of chlorophyll in the leaf, the presence of stomata, and the peculiar arrangement of the cells.

It should be ascertained if the stomata are above, even with, or below the epidermis; 'the nature of the epidermal cells, and, when present, the nature of the hypodermal.cells; the number of layers of palisade parenchyma and whether it is present on both surfaces of the leaf, and the nature of the outgrowths from the epidermal cells.

\section{KLIP BUCHU}

The cross-section of klip buchu (Plate ro8) has the following structure:

Epidermis. The epidermal cells of klip buchu are modified to form papillæ, the walls are yellowish white, and the papillate portion of the cell is nearly solid.

Hypodermis. The hypodermal cells are never intact because the mucilage contained in the cells swells when placed in water and breaks the thin side walls.

Upper Palisade Parenchyma. The palisade parenchyma is two layers in thickness. The cells of the outer layer are greatly elongated and are packed with chlorophyll. The inner layer of palisade cells is more irregular, and the cells are much shorter than the cells of the outer palisade layer.

Spongy Parenchyma. The spongy parenchyma cells are 


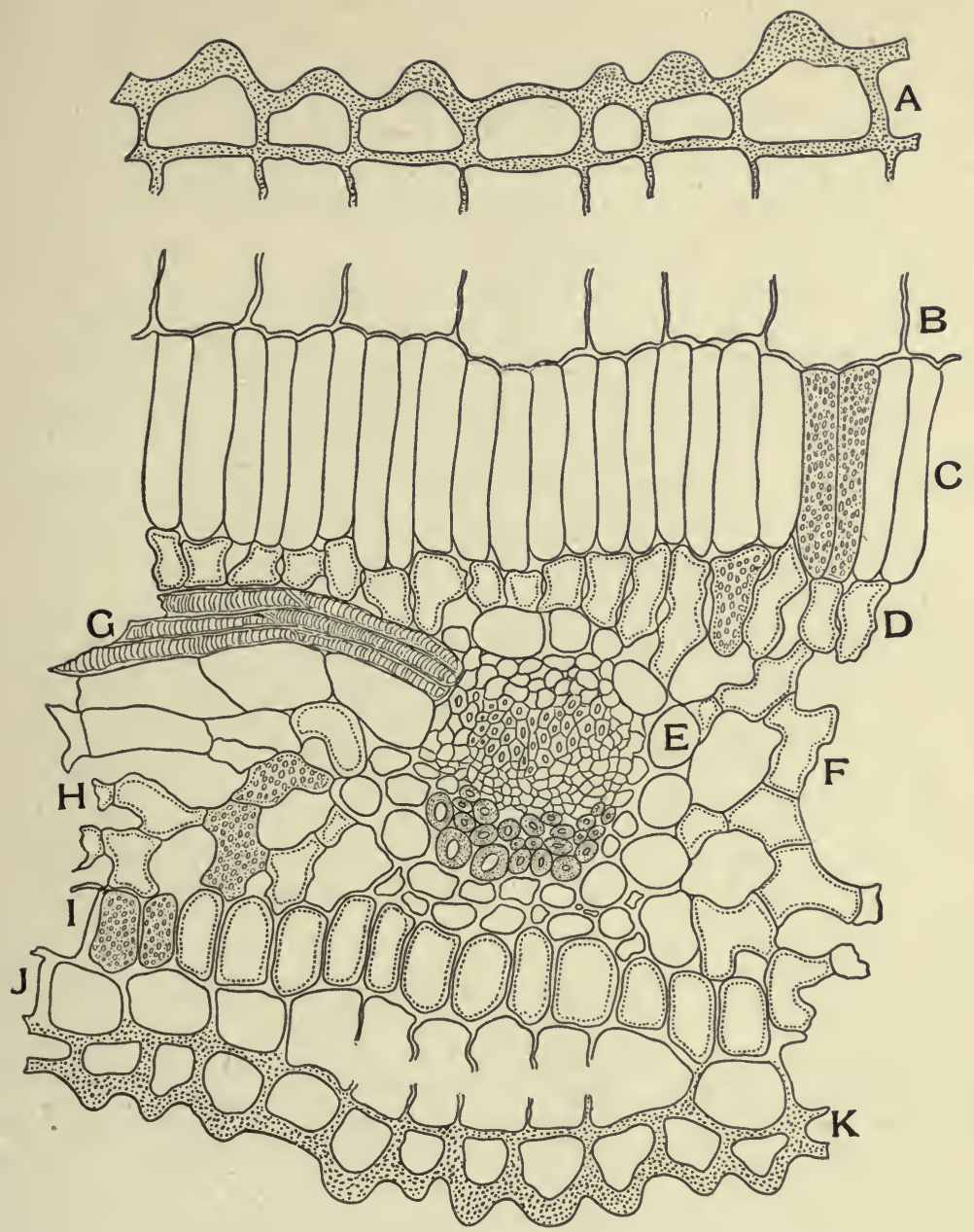

Cross-Section of Klip Buchu just over the Vein

A. Papillate upper epidermis.

$B$. Hypodermal cells with broken side walls, due to expansion of mucilage contents.

C. Palisade cells, showing two cells filled with chlorophyll.

$D$. Palisade like mesophyll.

E. Endodermis.

F. Vascular strand of vein.

G. Conducting cells with spirally thickened walls.

$H$. Characteristic leaf mesophyll.

$I$. Short, thick palisade cells on the under side of leaf, just under the vein.

$J$. Under hypodermal cells.

$K$. Papillate under epidermis. 
branched; therefore, large intercellular spaces occur between the cells.

Under Palisade Parenchyma. The palisade cells of the under epidermis are short and broad, and they contain fewer chlorophyll grains than the upper palisade cells of the upper epidermis. These cells occur only under the veins.

Under Hypodermis. The under hypodermal cells are shorter and broader than the upper hypodermal cells.

Under Epidermis. The under epidermal cells are modified to form papillæ which are similar to the papillæ of the upper epidermis.

Fibro-Vascular Bundle. The cells composing the vascular bundle are sieve cells, vessels, and fibres.

The sieve cells are small and the walls are white and angled.

The vessels have thick, white, angled walls.

The bast fibres are rounded in outline and the walls are thick and white.

Endodermis. The endodermal cells encircle the fibro-vascular bundles. The cells are large, thin-walled, and oval in shape.

Secretion Cells. Near the edges of the leaf are schizogenous secretion cavities surrounded by thin-walled secretion cells.

\section{POWDERED KLIP BUCHU}

When the leaf is powdered (Plate Iog), the cells are quite as characteristic in appearance. The upper epidermal cells (I) have thick-beaded, yellowish-white walls and papillate outer walls. No stomata occur on the upper surface. The under epidermis (2) with numerous stomata, is surrounded by the characteristic guard cells. The end walls are beaded as on the upper surface. . The palisade cells (3) appear as in the crosssection. The conducting cells $(4$ and 4$)$ are of the spiral and pitted type. The papillæ (5 and 5 ) are yery abundant in the powder and very characteristic. The fragments of the epidermis (6) are also abundant. The mesophyll (7) is characteristic, as it retains its form when powdered. The fibres (8) are usually associated with the conducting cells; occasionally they are found free as in the illustration. 
PLATE 109
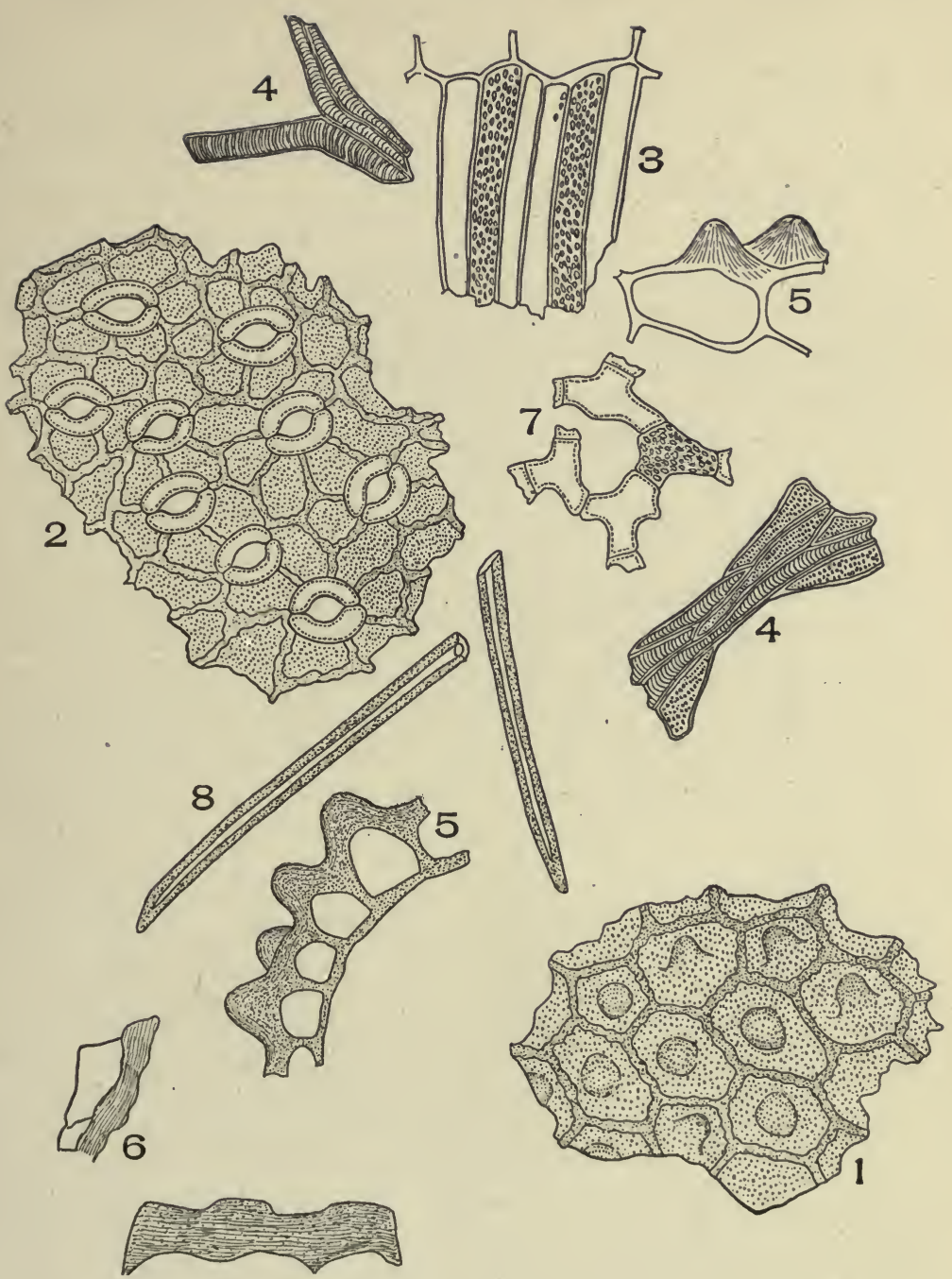

\section{PoWDERED KLIP BUCHU}

I. Upper epidermis. 2. Under epidermis. 3. Palisade cells with chlorophyll. 4 and 4 . Conducting cells. 5 and 5. Papillæ. 6. Fragments of the epidermis. 7. Mesophyll. 8. Fibres. 


\section{MOUNTAIN ' LAUREL}

Epidermis. The epidermal cells of mountain laurel are ofcasionally modified, as unicellular hairs (Plate I Iо, Fig. I), particularly in the region of the veins. The ordinary epidermal cells have thick outer walls and thin inner walls. Beneath many of the epidermal cells are large air-spaces.

Upper Palisade Parenchyma. The palisade parenchyma vary from four to five layers. The inner palisade cells are shorter and broader than the outer layer of cells.

Parenchyma. The parenchyma cells (Fig. 4) are rounded in form and they are arranged in the form of columns which are one cell in thickness above, but two to three cells in thickness near the under epidermis. Between each chain of cells is a larger intercellular space (Fig. 6). In a few of the cells are large rosette crystals.

Under Epidermis. The under epidermal cells are uniformly smaller than the upper epidermal cells.

It is thus seen that mountain laurel leaf has no hypodermal cells; no spongy parenchyma; no under palisade cells; no under hypodermal cells, and no secretion cavities.

\section{TRAILING ARBUTUS}

Epidermis. The epidermal cells of the trailing arbutus (Plate III, Fig. 2) are variable in size. Many of the cells are modified, as guard cells (Fig. I).

Parenchyma. The parenchyma cells are round and they are compactly arranged (Fig. 3) on the upper side of the leaf, but on the under side they are arranged in round, small, intercellular spaces (Fig. 5). In some of the intercellular spaces are rosette crystals (Fig. 7).

Under Epidermis. The under epidermal cells are smaller than the upper epidermal cells.

It will be seen that the structure of trailing arbutus leaf is very simple and that its structure is different from that of klip buchu and mountain laurel.

The structure of powdered leaves is very variable, yet characteristic for a given species. The leaves from the insect flower plant are collected with the stems, and ground and sold as a 


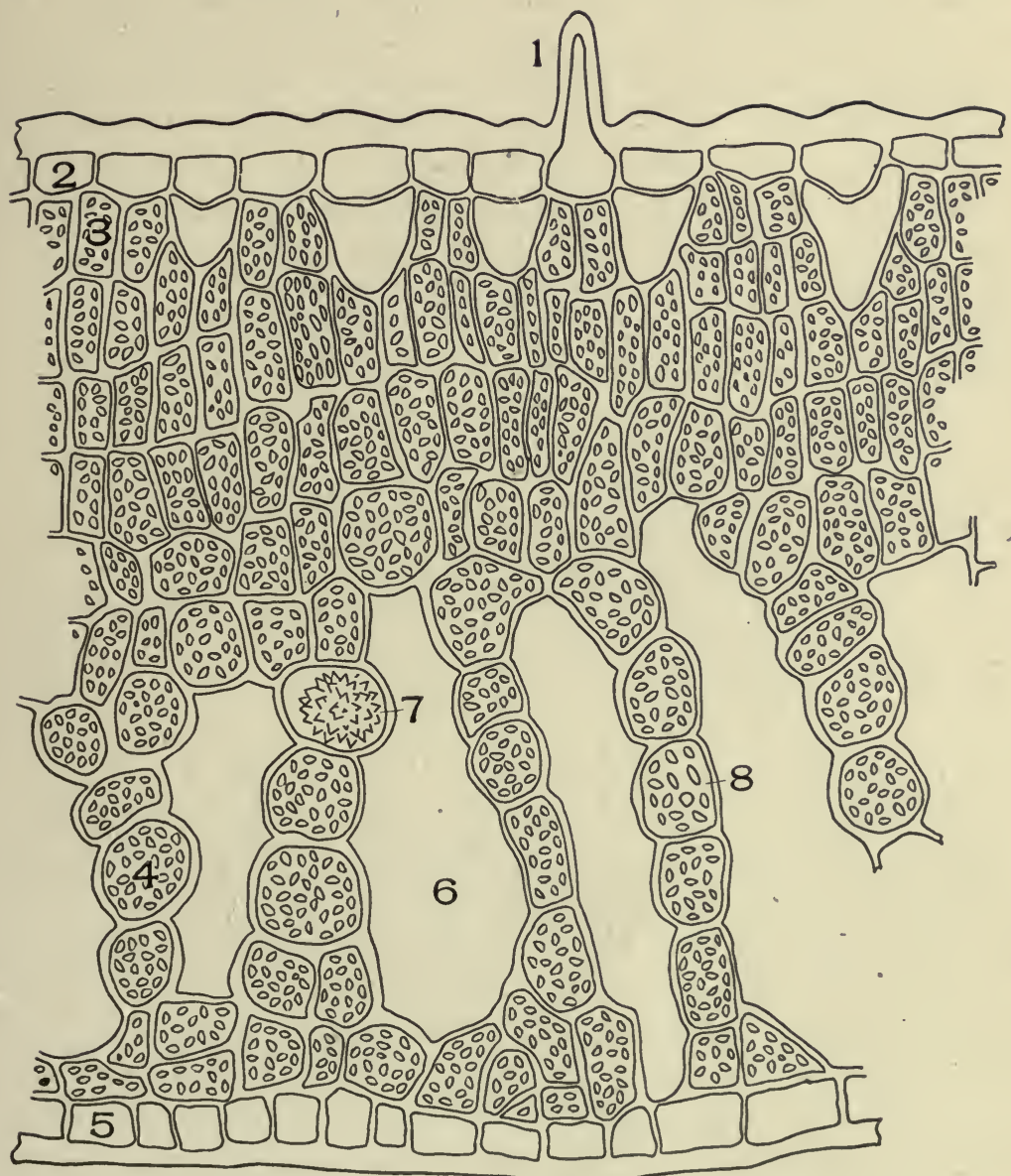

Cross-Section Mountain Laurel (Kalmia latifolia, L.)

I. Hair. 2. Epidermis. 3. Palisade parenchyma. 4. Parenchyma. 5. Under epidermis. 6. Intercellular space. 7. Rosette crystal. 8. Chlorophyll. 


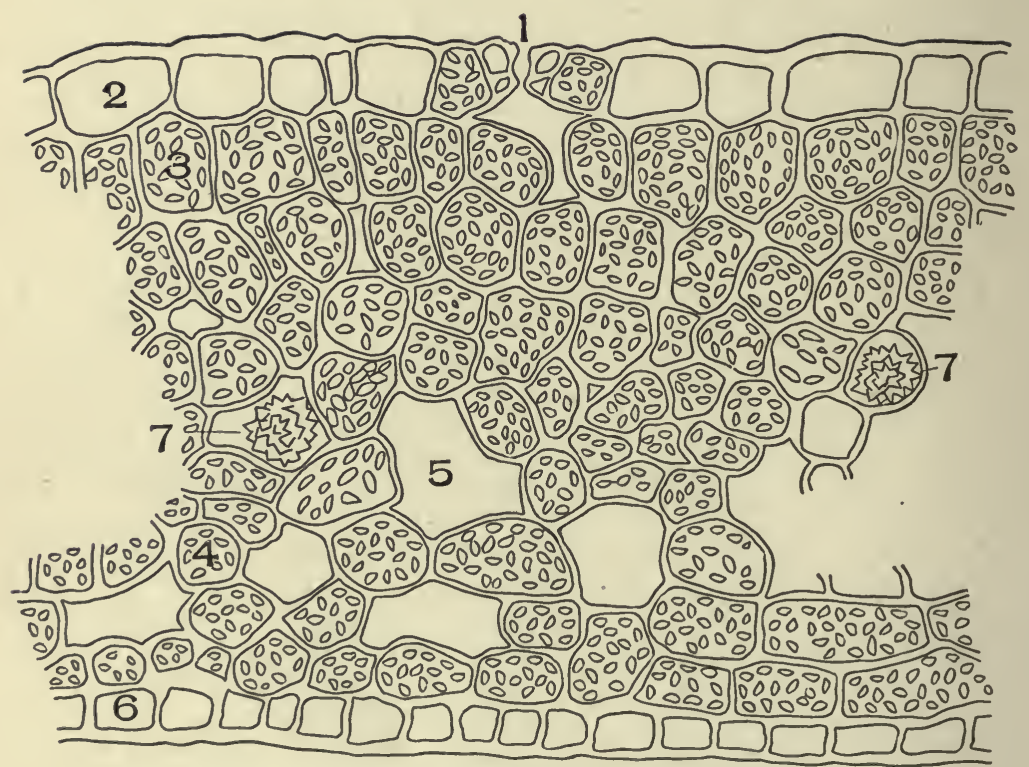

Croșs-Section Trailing Arbutus Leaf (Epigca repens, L.)

I. Stomata. 2. Epidermis. 3. Parenchyma. 4. Cell with chlorophyll. 5. Intercellular space. 6. Under epidermis. 7. Rosette crystal. 
substitute for insect flowers. These leaves, when powdered, show the following structure (Plate II2):

Both the upper and lower epidermis have stomata (Figs. I and 2), but they differ in that the surrounding cells of the upper epidermis are wavy, while the corresponding cells of the under epidermis are similar, though the under epidermis has many attached hairs (Figs. 3 and 4 ). The T-shaped hairs form the most abundant element of the powder. They are similar in structure to those found on the scales and stem. Fragments of the mesophyll have round cells and contain chlorophyll (Fig. 6). The conducting cells are spiral or reticulate.

The different cells of the leaf differ greatly in structure, in amount, and in arrangement. In uva-ursi, boldus, pilocarpus, eucalyptus, and chimaphila leaves the outer walls of the epidermal cell is very thick. In uva-ursi leaves this thick wall appears bluish green when viewed under low power of the microscope.

In belladonna, stramonium, henbane, peppermint, spearmint, digitalis, and horehound, the outer wall of the epidermal cells is thin.

In witch-hazel, stramonium, coca, phytolacca, and peppermint there is a single layer of palisade parenchyma on the upper surface only of the leaf.

In senna there is one layer of palisade parenchyma on the upper and one layer on the under side of the leaf. In matico and tea leaves there are two layers of spongy parenchyma on the upper side of the leaf.

In chestnut leaves there are three layers of palisade parenchyma on the upper side of the leaf.

In eucalyptus leaves the entire central part of the leaf, with the exception of the secretion cells and fibro-vascular bundle, is made up of the palisade parenchyma.

In some leaves no palisade parenchyma occurs. Trailing arbutus (Plate III) is an example of such a leaf.

In stramonium leaves the spongy parenchyma is strongly branched; in mountain laurel the spongy parenchyma is mostly non-branched and circular in form, as in trailing arbutus (Plate III, Fig. 3), and as occurs in the midrib portion of most leaves.

In stramonium and chestnut are found rosette crys- 


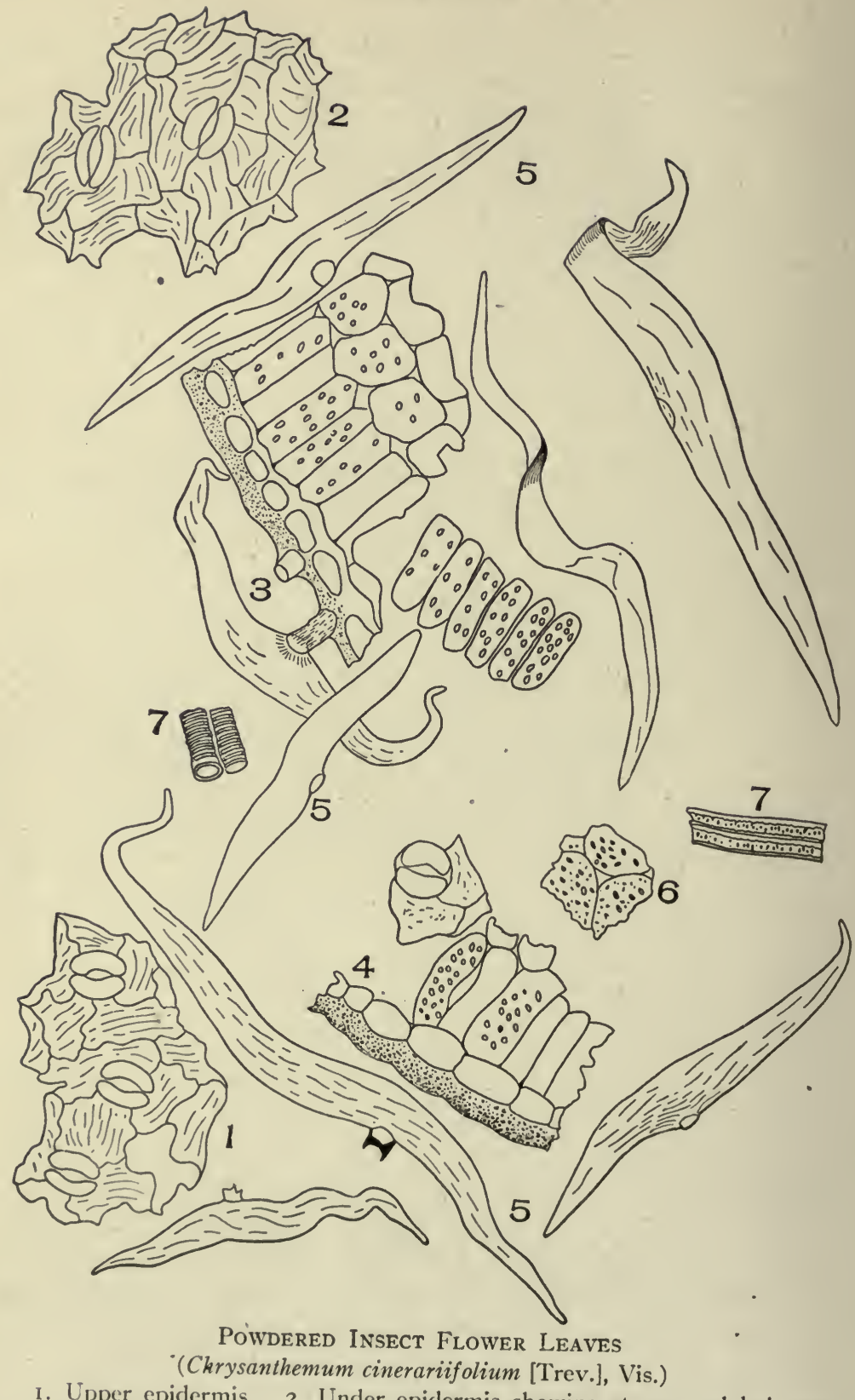

I. Upper epidermis. 2. Under epidermis showing stoma and hair scar. 3. Cross-section of under epidermis with attached hair. 4. Cross-section of upper epidermis. 5. Hairs. 6. Mesophyll with chlorophyll bodies. 7. Con-
ducting cells. 
tals. In henbane, coca, and senna are found prisms. In belladonna, scapola, and tobacco leaves are found micro-crystals. In most leaves no crystals occur. In witch-hazel and tea leaves stone cells occur, but in most leaves there are no stone cells. In eucalyptus, thyme, jaborandi, buchu, rosemary, and white pine leaves are secretion cells; while in belladonna, stramonium cells occur. In senna and coca leaves are crystalbearing fibres; most leaves do not have crystal-bearing fibres.

In chimaphila and uva-ursi there are no outgrowths from the epidermal cells.

In senna, witch-hazel, chestnut, and coca, numerous nonglandular hairs occur on the epidermis. In tobacco, belladonna, henbane, pennyroyal, peppermint, and spearmint both glandular and non-glandular hairs occur on the epidermis.

When studying leaves there should be considered the absence or presence of outgrowths and their nature; the nature of the epidermis and, when present, the number of layers of the hypodermis; the nature of the stoma, whether raised above, even with, or below the level of the epidermis; the number of layers, and the distribution, when present, of the palisade parenchyma; the form and amount of the spongy parenchyma; the absence or presence of secretion cells; the nature and form of the fibro-vascular bundles, and the nature and amount of the organic and inorganic cell contents. 


\section{CHAPTER VII}

\section{FLOWERS}

The histological structure of flowers is readily seen in the powder; therefore, in studying flowers, it is not necessary to section the various parts. Each part of the flower should be isolated and powdered separately and each separated part studied. In each case the powders will contain surface, cross-, and radial sections of the parts powdered. While studying flowers, special attention should be given to the pollen grains, to the papillæ of the petals, to the papillæ of the stigma, and, in certain flowers, to the style tissue. In the composite flowers special attention should also be given to the involucre scales, to the scales of receptacle, and, when present, to the pappus. In addition, attention must be given to secretion cavities, as in cloves.

\section{POLLEN GRAINS}

Pollen grains are one of the most characteristic elements found in powdered flowers, because they are so small that they are not broken up when the drug is milled.

The two principal groups of pollen grains are, first, those with non-spiny walls (Plate II3); and, secondly, those with spiny walls (Plate II4), as shown in the two charts.

In lavender flowers the pollen grains have six constrictions of the outer wall. This wall is slightly striated and the cell contents are granular.

In clover flowers the pollen grains are mostly rounded in outline, the wall is uniformly thickened, and cell contents are coarsely granular.

In belladonna flowers the pollen grains terminate in three blunt points.

In Spanish saffron the pollen grains are spherical and the cell contents are granular. 
PLATE II3
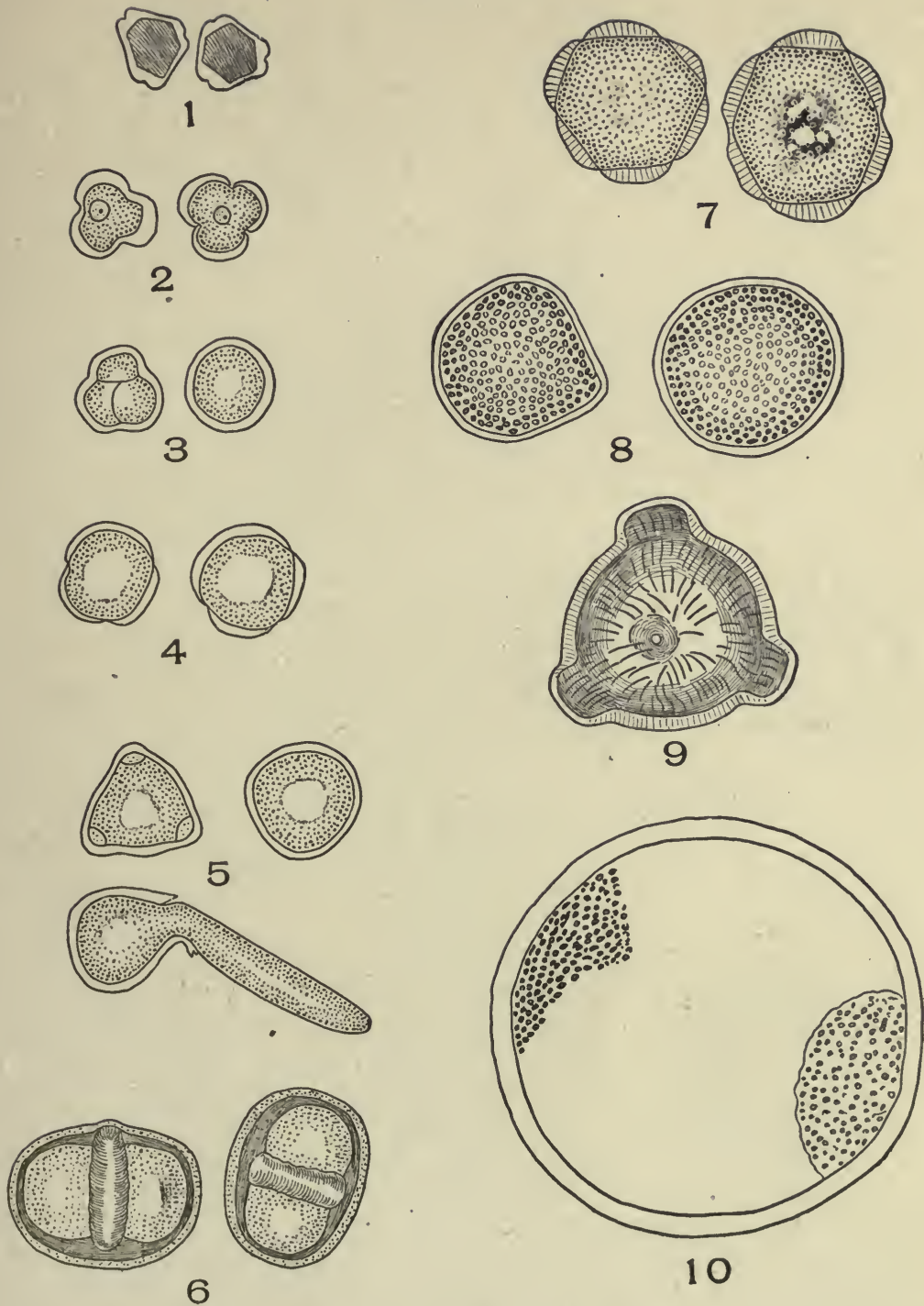

\section{Smooth-walled Pollen Grains}

I. Cloves (Eugenia caryophyllata, Thunb.). 2. Santonica (Artemisia pauciflora, Weber). 3. Elder (Sambucus canadensis, L.). 4. Century minor (Erythrcea centaurium [L.], Pers.). 5. Pichi (Fabiana imbricata, R. and P.). 6. Cyani. 7. Lavender (Lavandula officinalis, Chaix.). 8. Clover (Trifolium pratense, L.). 9. Belladonna (Atropa belladonna, L.). Io. Spanish saffron (Crocus sativus, L.). 
PLATE II 4

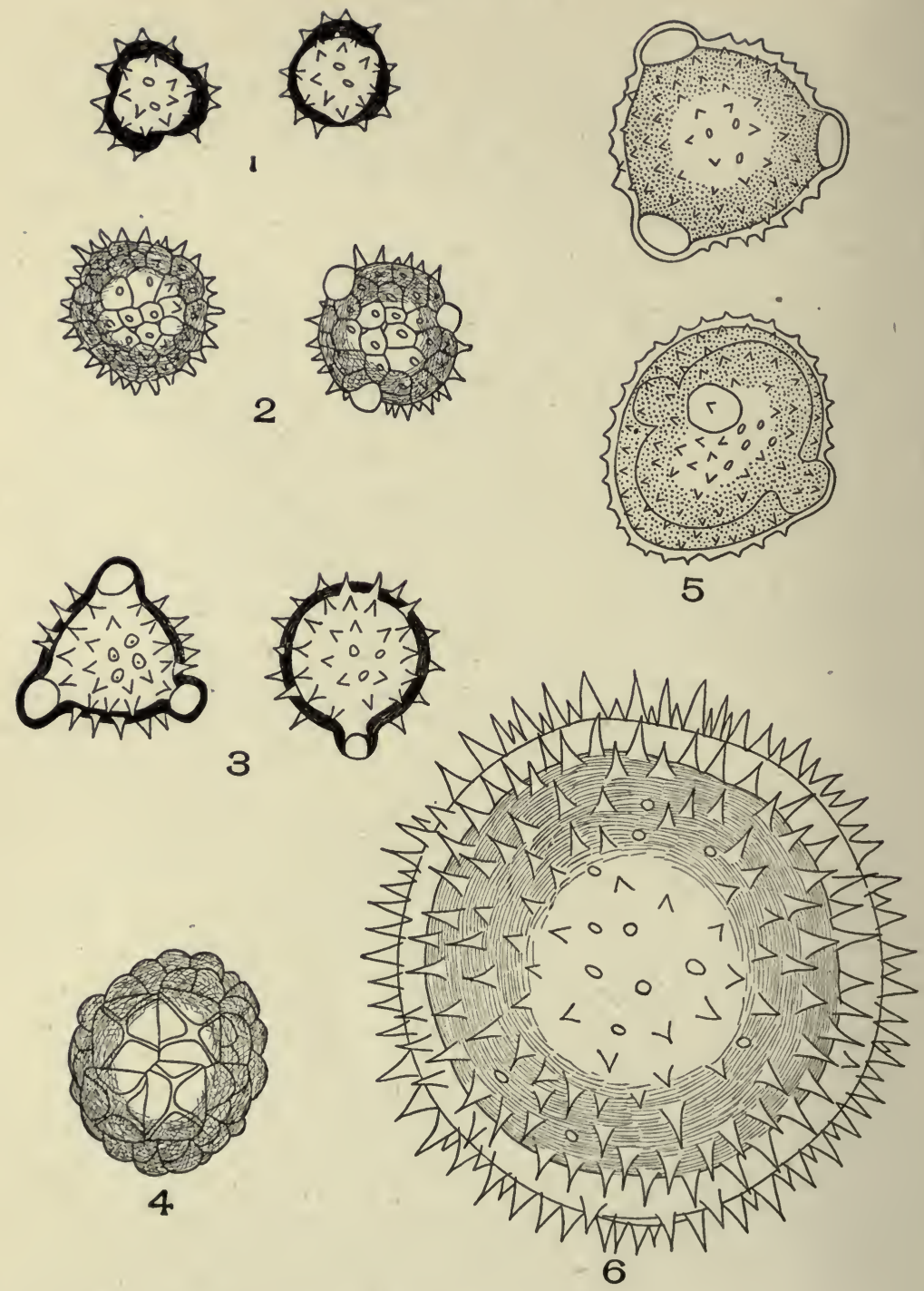

Spiny Walled Pollen Grains

I. Anthemis (Anthemis nobilis, L.).

2. Arnica (Arnica montana, L.).

3. Calendula (Calendula officinalis, L.).

4. Cassia flowers.

5. American saffron (Carthamus tinctorius, L.).

6. Blue malva flowers (Malva sylvestris, L.). 
The non-spiny-walled pollen grains differ not only in microscopic appearance, but also in size. Clove pollen grains are the smallest, while Spanish saffron pollen grains are the largest.

\section{NON-SPINY-WALLED POLLEN GRAINS}

In cloves the pollen grains show a six-sided, angled cavity and an outer wall which terminates in three slightly pointed, narrowly notched portions, separated by nearly straight walls.

In santonica the pollen grains have smooth, unequally thickened walls, which are strongly constricted at three points, the outline resembling three half-circles placed together.

In elder flowers the pollen grains appear circular or threeparted. The wall is of nearly uniform thickness, even at the constricted part of the grain.

In century minor the pollen grains show three pronounced restrictions. The wall at these points is very thin. In pichi flowers the pollen grains are either circular or three-sided and three-pointed. Inside of each point there is a nearly white pore. In some of the grains the pollen tube has grown out of one of the pores.

In cyani flowers the pollen grains are longer than broad and the cell contents appear to be divided into two end portions and an elevated middle portion

\section{SPINY-WALLED POLLEN GRAINS}

In anthemis the pollen grains have unequally thickened walls constricted in three places. The spines are short, broad at the base, and sharp-pointed.

In arnica flowers the pollen grains show three light-colored pores and numerous short spines.

In calendula flowers the pollen grains show one or more pores, typically three pores. These pores appear as white spots, and the wall immediately over the pore is smooth and thinner than the remaining part of the wall; the spines are very numerous.

In cassia flower pollen grains the outer wall is extended into a number of rounded projections which are frequently arranged in sets of fours.

In American saffron flowers the pollen grains show one, two, or three light-colored pores; the spines are short and broad. 
In blue malva flowers the pollen grains are spherical and the outer wall extends into numerous spinelike projections.

It will be observed that the spiny-walled pollen grains differ greatly in size, the smallest being the pollen grain of anthemis and the largest being the pollen grain of blue malva flowers.

In matricaria are numerous, greenish-brown, spiny-walled pollen grains. In anthemis are multicellular, uniseriate nonglandular hairs with three or four short, broad, yellowwalled basal cells and a greatly elongated, thin, gray-walled apical cell.

In arnica are multiseriated branched hairs of the pappus, and numerous large, yellowish, spiny-walled pollen grains.

\section{STIGMA PAPILLE}

The papillæ of the stigma of most flowers form a characteristic element even when the flower is powdered. In the case of composite flowers the papillæ of the disk and ray flowers differ. In American saffron the papillæ of the style differ in a recognizable way from the papillæ of the stigma.

The papillæ of the stigma of the ray and disk flowers of arnica, anthemis, matricaria, and insect flowers differ greatly. Even the papillæ̈ of the stigma of the ray and disk flowers differ. In all cases observed the papillæ of the ray flowers are smaller than the papillæ of the disk flowers.

The papillæ of the stigma of saffron (Plate II5, Fig. 3) are long and tubular. These papillæ are nearly uniform in diameter, and the apex is blunt and rounded. The wall is slightly granular in appearance. The papiilæ of the stigma of American saffron (Plate I 6, Fig. 2) are short and tubular. Each papilla is broadest at the base and tapers to a slender point. The papillæ of that part of the style which emerges from the corolla (Plate II6, Fig. I) are large and curved, and the walls are very thick. The apex of the papilla is frequently solid.

The papillæ of the stigma of the ray flowers of anthemis (Plate II7, Fig. I) have thin, slightly striated walls; while the papillæ of the stigma of the disk flowers (Plate II 7, Fig. 2) are longer, the walls are thicker, and the cell content is denser.

The papillæ of the stigma of the ray (Plate II 7, Fig. 3) and 
PLATE II5

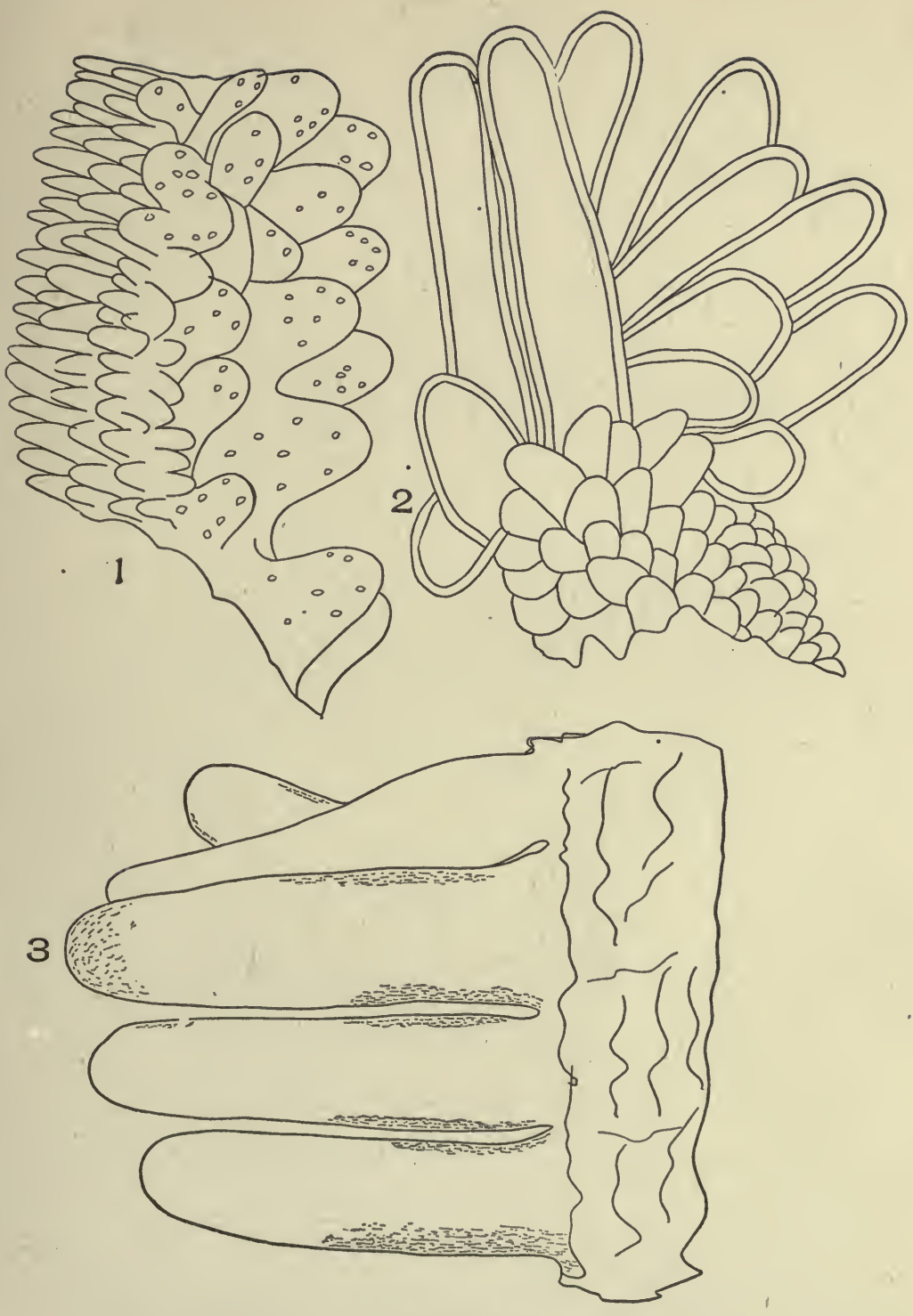

\section{PAPILLE}

I. Arnica ray flowers (Arnica montana, L.).

2. Insect flower disk (Chrysanthemum cinerariifolium [Trev.], Vis.).

3. True saffron (Crocus sativus, L.) 
PLATE II6
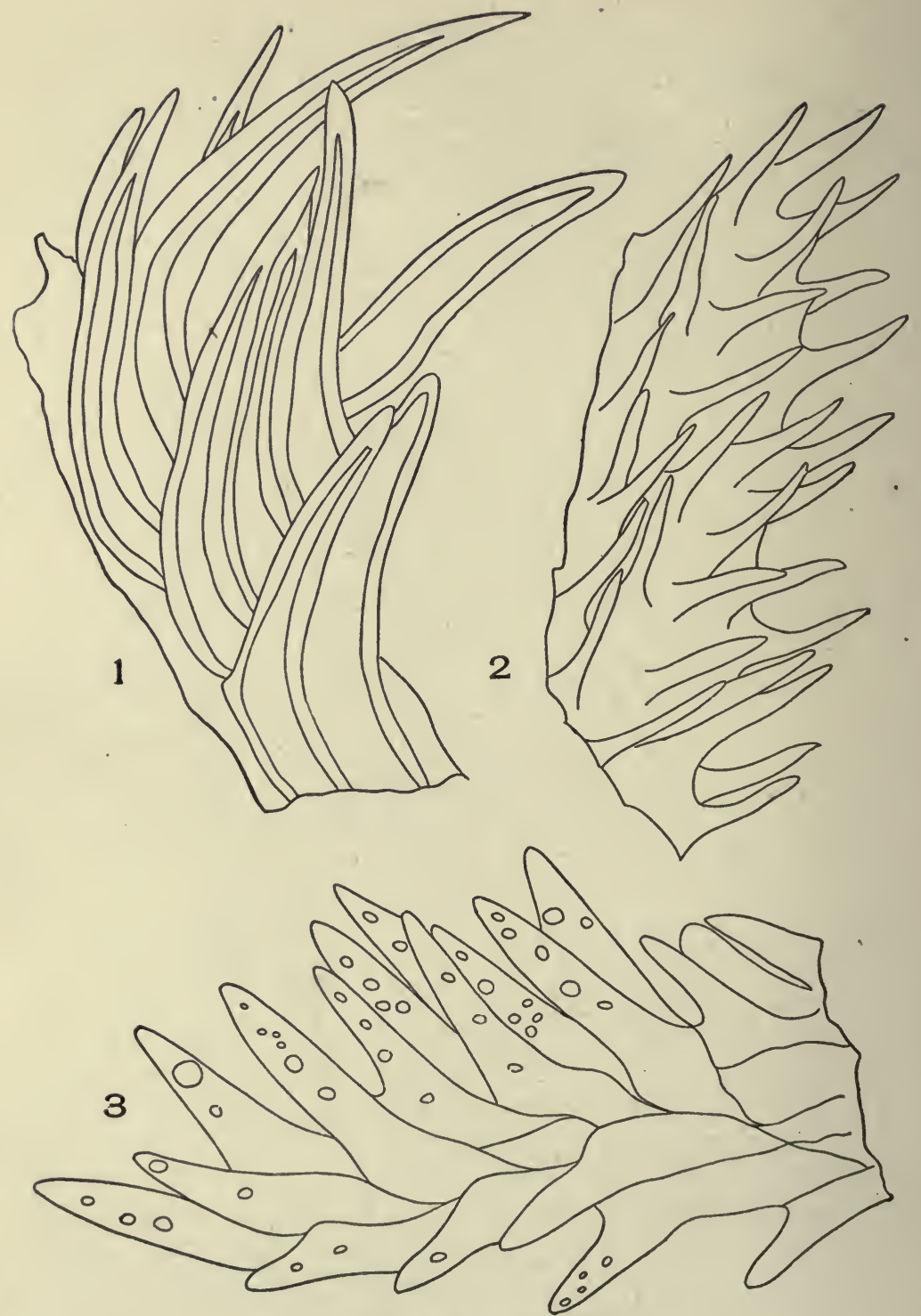

Papille of Stigmas

I. Stigma papillæ of American saffron (Carthamus tinctorius, L.) from that part of the style that emerges from the corolla.

2. Papillæ from the upper part of the stigma of American saffron.

3. Papillæ of the stigma of the disk flowers of arnica (Arnica montana, L.). 


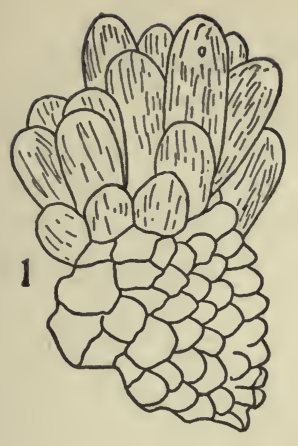

PLATE 117
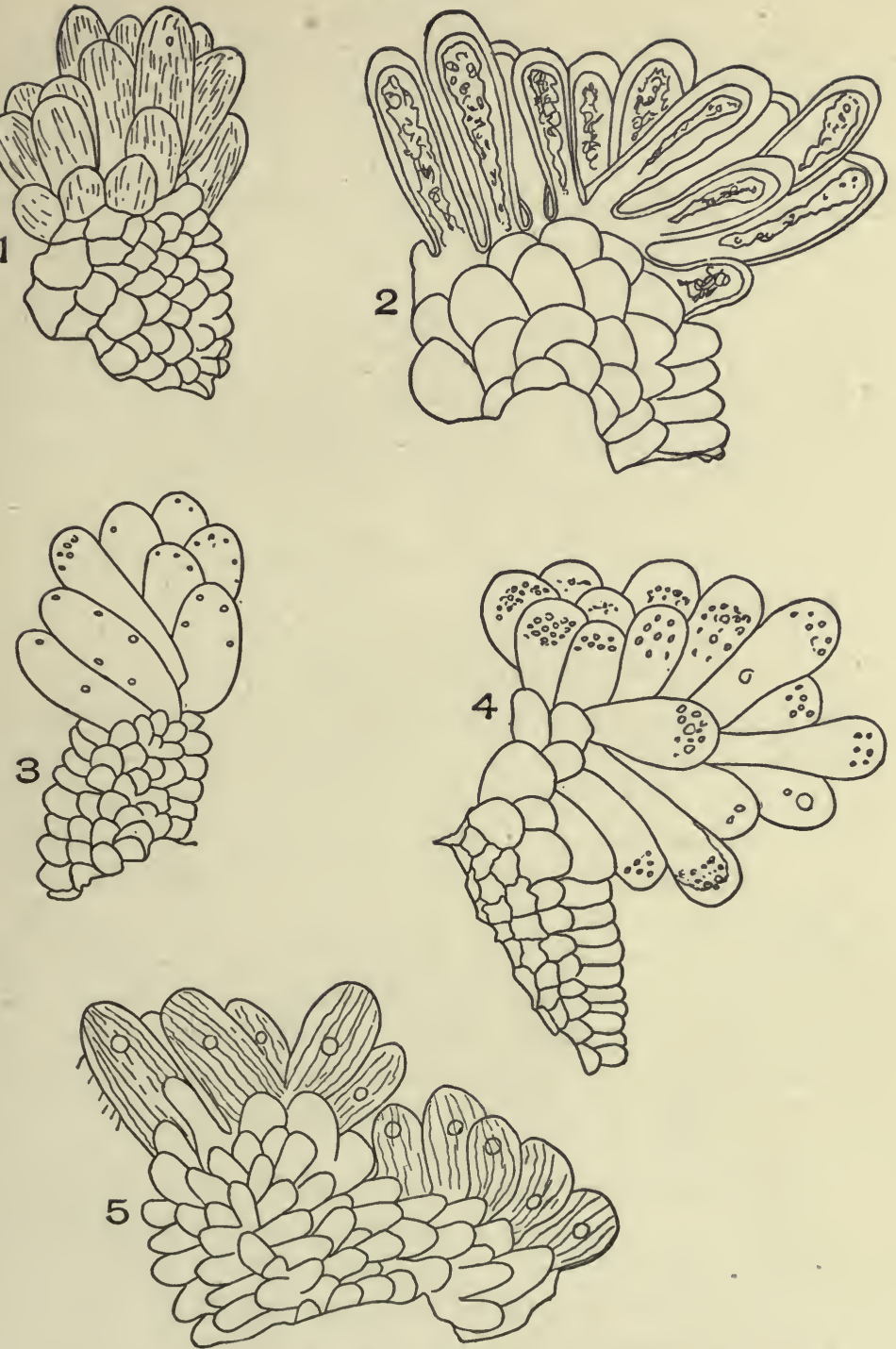

Papille of Stigmas

I. Stigma papillæ of the ligulate flowers of anthemis (Anthemis nobilis, L.).

2. Stigma papillæ of the tubular flowers of anthemis

3. Stigma papillæ of the ligulate flowers of matricaria (Matricaria chamomilla, L.).

4. Stigma papillæ of the disk flowers of matricaria.

5. Stigma papillæ of the ligulate flowers of insect flower (Chrysanthemum cinerariffolium [Trev.], Vis.). 
disk flowers (Plate 117 , Fig. 5) of matricaria are similar in structure, but the papillæ of the disk flowers are larger.

The papillæ of the stigma of the ligulate flowers of insect flowers (Plate II 7, Fig. 5) are tubular; the walls are striated, and in each papilla there is a small yellow globule, while the papillæ of the disk flowers (Plate II5, Fig. 2) are long and tubular, and the walls are thick.

The papillæ of the stigma of the ray flowers of arnica (Plate I15, Fig. I) are very short and tubular. The walls are thin and the cell contents appear as small, bright-yellow globules, while the papillæ of the stigma of the disk flowers (Plate II6, Fig. 3) are broadest at the base, the apex is pointed, and the yellow globules are larger.

The solitary hairs are divided into the branched and nonbranched hairs.

\section{POWDERED INSECT FLOWERS}

The microscopic examination of insect powder is difficult for the reason that there are so many elements to be constantly kept in mind. The parts of the flower which contribute characteristic cells are the stem, involucre, ray flowers, disk flowers, and the receptacle. In each of these parts there are many different types of cells.

There are practically two types of flowers found in insect. powder of commerce: first, closed or immature flowers, and secondly, open or mature flowers. As explained above, the half-open flowers consist largely of the two above-named varieties. Let us first consider the structure of the closed insect flowers as illustrated in Plate II8.

The involucre has many characteristic cells. The more prominent ones seen in the powder are the edge of the scale with the attached hair (Fig. I). These hairs (Fig. 3) are T-shaped. The terminal cell is expanded laterally, and it terminates in two points. Connecting the terminal cell with the epidermis are two or three cells which are slightly longer than broad. In the powder the terminal cell is usually attached to fragments only of the supporting cells. Fibres of the bracts have thick, wavy, porous walls, and they have a tendency to occur in masses. The upper epidermis (Fig. 4) of the ray-flower petal is promi- 
PLATE 118

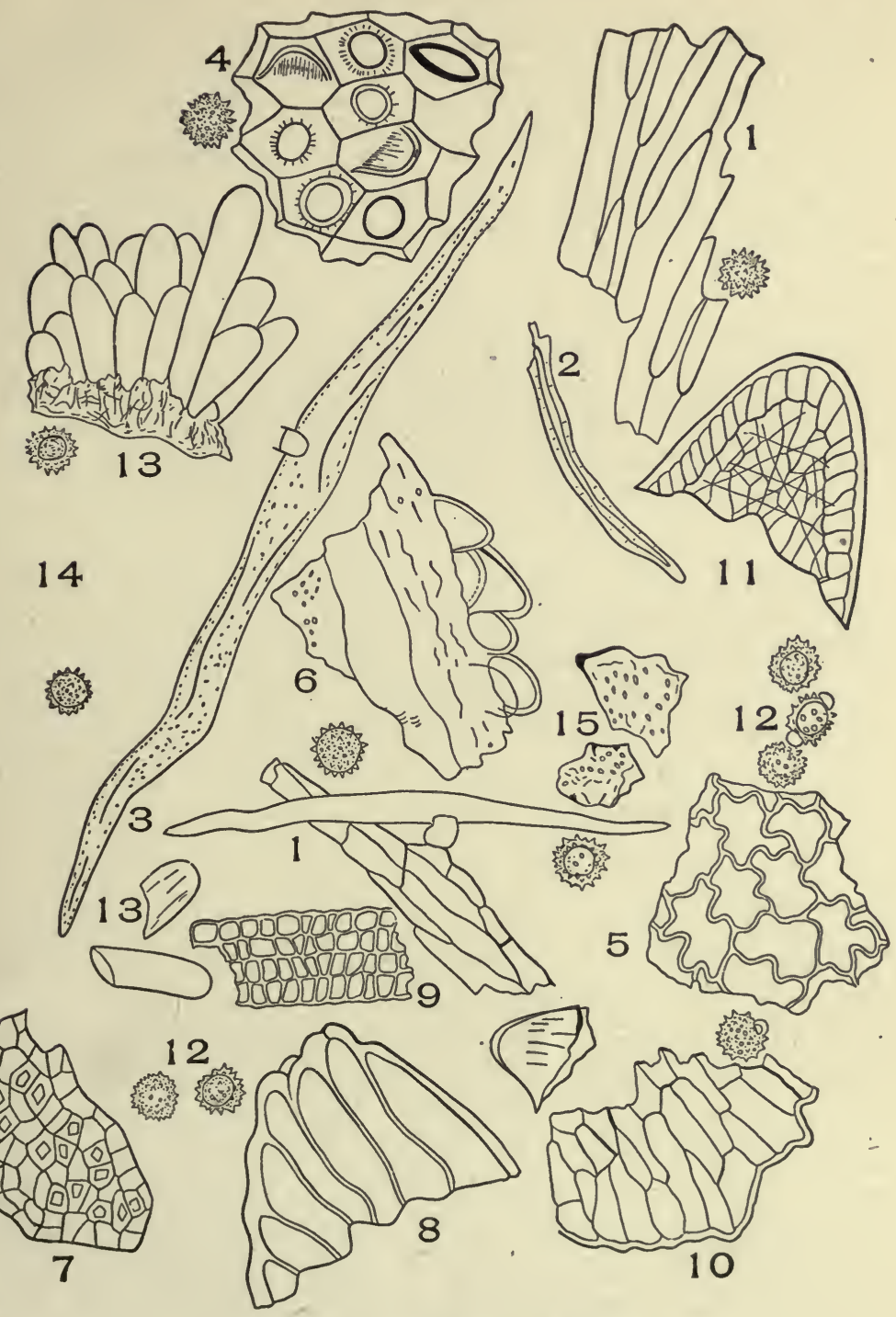

Powdered Closed Insect Flower

(Chrysanthemum cinerariifolium, [Trev.] Vis.)

I. Edge of scale. 2. Fibre of scale. 3. Hairs. 4. Upper epidermis of ray flower. 5. Under epidermis of ray flower. 6. Cross-section of ray petal. 7. Parenchyma of ray flowers with crystals. 8. Lobe of disk petal. 9. Filament tissue. I0. Calyx tissue. I1. Lobe of stamen. 12. Pollen. 13. Papillæ of stigma. 14. Secretion cavity with surrounding cells. I5. Parenchyma of the receptacle. 
nently papillate. The under epidermis consists of wavy cells without papillæ. Another view of the papillæ is shown in Fig. 6. The parenchyma of the ray flowers (Fig. 7) contain cubical crystals. The lobe of the disk-flower petal (Fig. 8) is papillate at the end, the terminal cells have thick outer and thin inner walls. The filament tissue (Fig. 9) is composed of nearly square cells. The calyx tissue (Fig. Io) is made up of thin-walled cells with slightly papillate margins. The lobe of the stamen (Fig. II) consists of nearly uniform epidermal cells which are in contact throughout their long diameter, while the hypodermal cells are thin-walled and angled. The pollen grains (Fig. I2) are dark yellowish green, thin, and the wall does not appear perforated by pores. The papillæ of the stigma (Fig. I3) are clustered, club-shaped, and nearly white in color. They are usually found detached in the powder. All parts of the pistil contain secreting cells, but the most conspicuous secreting cavities (Fig. I4) are those of the ovary. These cavities appear brownish in color and are surrounded by small cells which appear indistinct on account of the great number of superimposed cells. The parenchyma of the receptacle occurs in fragments which have strongly marked porous walls.

\section{OPEN INSECT FLOWERS}

Many of the structures of open insect flowers (Plate II9) are similar to those found in the closed flower. There is practically no difference in the edge of the scale (Fig. I); or the fibre of the scale (Fig. 2); or the T-shaped hairs (Fig. 3); or the upper epidermis of the ray flower (Fig. 4); or the under epidermis of the ray flower (Fig. 5); or the cross-section of the ray petal (Fig. 6); or the lobe of the disk petal (Fig. 7); or the filament tissue (Fig. 8); or the lobe of the stamen (Fig. 9); or the papillæ of the stigma (Fig. I2); or the parenchyma of the receptacle (Fig. I5). The difference in structure is found, first, in the involucre scales, which are more fibrous than the scales of the closed flowers; secondly, in the pollen (Fig. I I), which is less abundant than in the closed flower; it is also lighter in color and usually shows the wall perforated by three pores; thirdly, the outer layers of the achene consist of thick, porous-walled stone cells (Fig. I3), which occur singly or in groups; fourthly, 


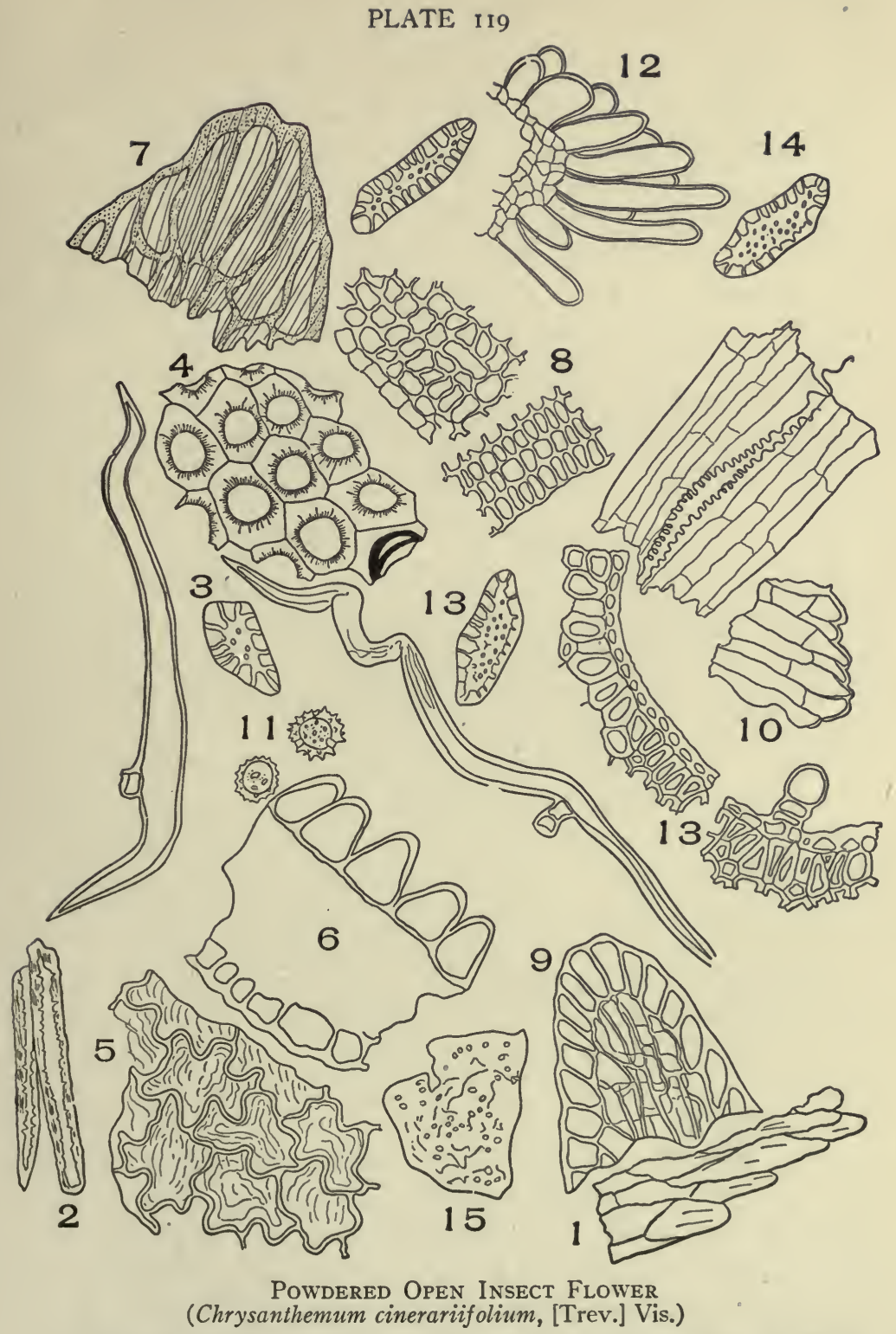

I. Edge of involucre scale. 2. Fibres of involucre scale. 3. Hairs. 4. Upper epidermis of ray flower. 5. Under epidermis of ray flower. 6. Cross-section of ray petal. 7. Lobe of disk flower. 8. Filament tissue. 9. Lobe of stamen. IO. Calyx tissue. II. Pollen. I2. Papillæ of the stigma. I3. Stone cells from the achene and cross-section of achene. I4. Secretion cavity with surrounding cells. I5. Parenchyma of the receptacle. 
the secretion cavity is broader and darker in color (Fig. I4). These differences enable one at once to distinguish between the closed and open insect flowers. Now, since the half-closed flowers consist almost wholly of a mixture of equal parts of closed and open flowers, it follows that the elements of these two flowers will be mixed in about equal proportions. Thus we are able to distinguish microscopically the three commercial varieties of insect powder-namely, closed insect flowers, open insect flowers, and half-open insect flowers.

Insect flowers are the most valuable vegetable insecticide known; yet much of its effectiveness is destroyed by the adulterants which are so readily identified by the compound microscope.

\section{POWDERED WHITE DAISIES}

A common adulterant found in open insect flowers is the flower-heads of European daisy (C. leucanthemum). Examination of powdered flowers exported from Europe shows that the entire flower-head is ground and mixed with the insect flowers. In the cheaper varieties of open flowers, only the tubular flowers are added after they have been separated from the heads by crushing and sifting. These tubular flowers so closely resemble the tubular flowers of the true insect flowers that it is practically impossible to distinguish between them macroscopically. The quickest and surest way to identify them is to reduce a portion of the flowers to a fine powder and examine it microscopically.

Certain structures of the white daisies (Plate I20) are somewhat similar to those found in insect flowers. These structures are the papillæ of the ray petal (Figs. 3, 5, and I3), the lobe of the disk petal (Fig. I4), and the lobe of the stamen and the pollen (Fig. 8).

The differences are as follows: The under epidermis of the ray flowers is composed of wavy cells which are more elongated than the ray flowers of the under epidermis of the ray petal of insect flower. The filament tissue is made up of slightly beaded cells instead of smooth-walled cells. The papillæ of the stigma are smaller than the papillæ of insect flowers. The most striking difference is found in the structure of the achene. The epidermal tissue of the achene is composed of palisade cells (Fig. Io), which in the mature form have thick white walls and scarcely any 


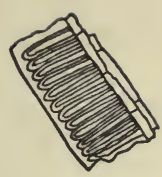

10
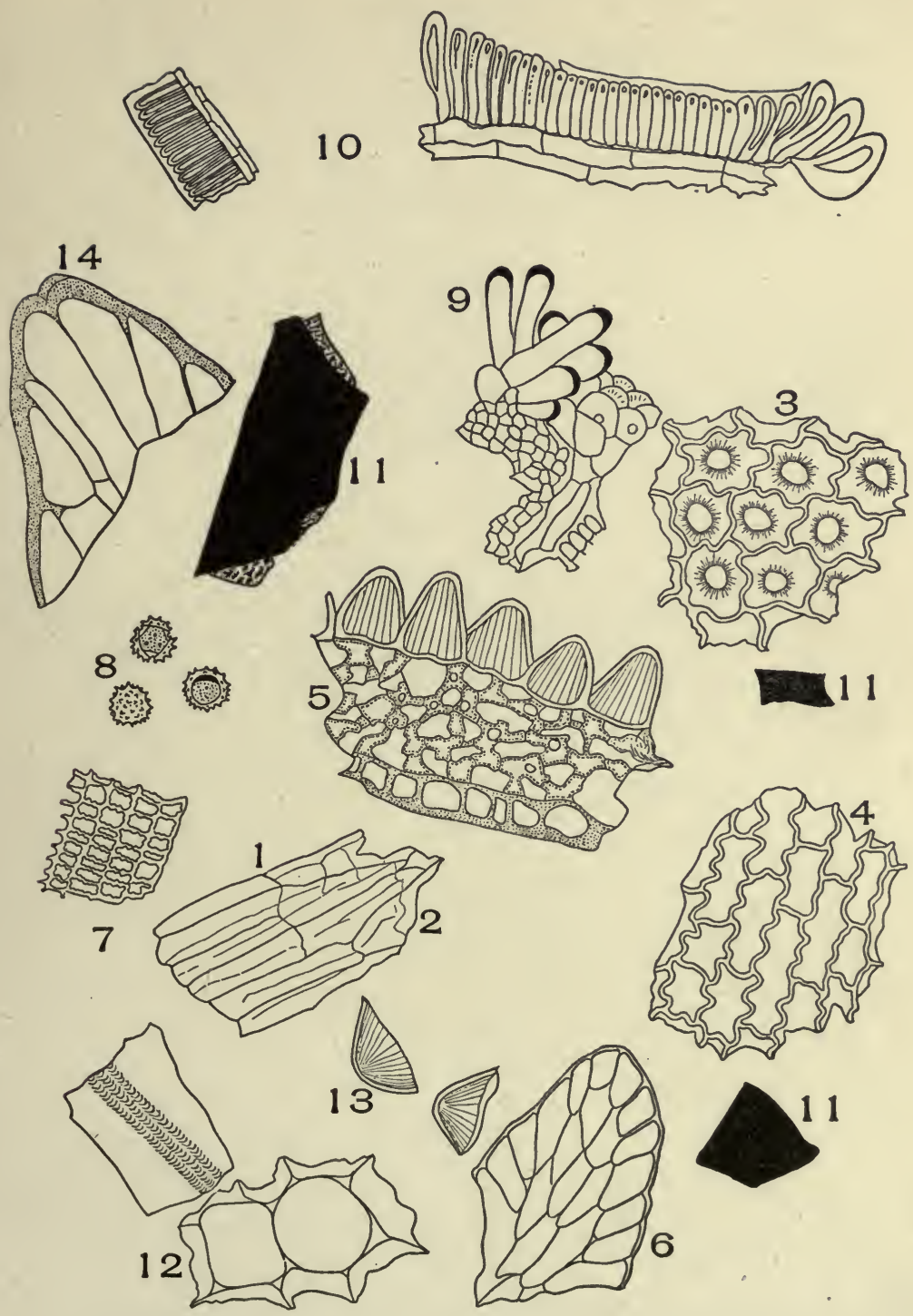

Powdered White Daisies (Chrysanthemum leucanthemum, L.)

I and 2. Scale tissue. 3, 5 and 13. Papillæ of petals. 4. Scale tissue. 6. Lobe of ray petal. 7. Filament tissue. 8. Pollen. 9. Papillæ of stigma. 10. Palisade cells of achene. I1. Resin masses. I2. Parenchyma of receptacle. I4. Lobe of dish petal. 
cavity. These cells swell perceptibly when placed in water. The other striking feature of the achene is the bright red resin masses which occur free in the field. Even a small trace of daisies in insect powder can be identified.

When studying flowers there should be considered the number and structure of pollen grains; the nature of the papillæ of the stigma and the petals; the nature of the hairs of the corolla and calyx, when present. In the composite flowers we should also consider the structure of the involucre scales, and, when present, the structure of the receptacle scales, as in the case of anthemus, and of the pappus hairs, as in the flowers of arnica, boneset, grindelia, and aromatic goldenrod. 


\section{CHAP'TER VIII}

\section{FRUITS}

There is great variation in the structure of fruits, such a variation, in fact, that no one fruit has a structure typical of all the other fruits. Each fruit, however, has a pericarp and one or more seeds. The amount and structure of the cells forming the pericarp and the seeds of fruits differ in different fruits, but for each fruit there is a normal amount of, and a characteristic, cellular structure. Nearly all the important medicinal fruits are cremocarps .or umbelliferous fruits.

The plan of structure of cremocarps is similar, but they all have a different cellular structure. The epidermis may be simple or modified as papillæ or hairs. The secretion cavities may be absent (conium), or, when present, variable in number - cultivated celery seed has six, wild celery seed up to twelve, and anise up to twenty. The vascular bundles may be large or small. The endocarp cells may be two or more layers in thickness. The spermoderm may be thin or thick.

The endosperm cells may vary in size and the cell contents may vary.

\section{CELERY FRUIT}

The fruit of celery (Plate I2I), like other umbelliferous fruits, is composed of the pericarp and the seed.

The pericarp is composed of epicarp cells, mesocarp cells, endocarp cells, and in each rib a vascular bundle. The seed is composed of the spermoderm, endosperm, and embryo. Each of these parts has a characteristic structure.

Epicarp. The cells of the epicarp (Fig. I) are papillæ and the outer wall is striated. The papillæ do not show, however, unless the cell is cut across the centre, which is the point at which the papillæ are located.

Mesocarp. In the rib part of the mesocarp (Fig. 2) is a 


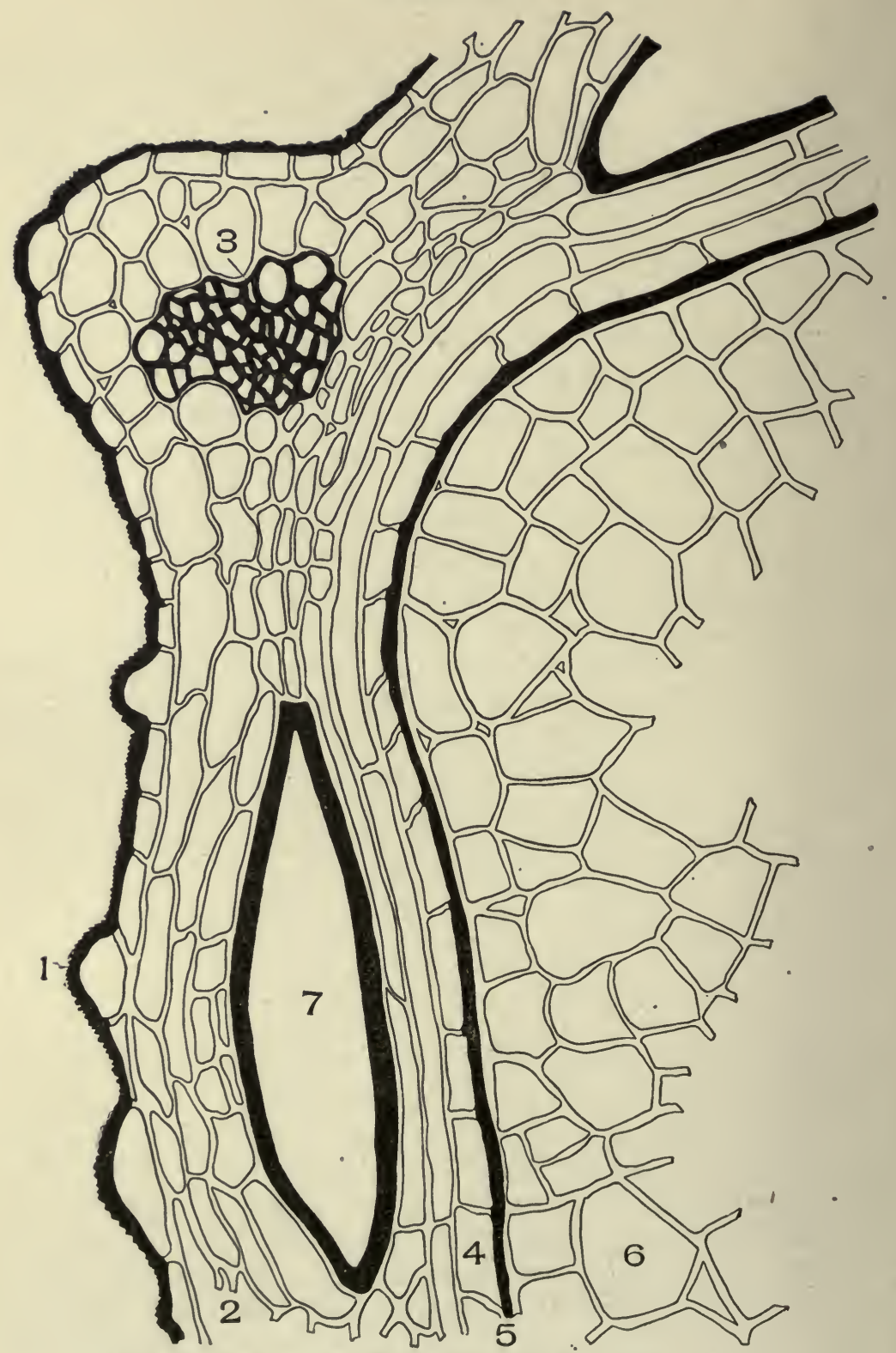

Cross-Section of Celery Fruit (A pium graveolens, L.)

I. Epicarp. 2. Mesocarp. 3. Vascular bundle. 4. Endocarp.

5. Spermoderm. 6. Endosperm. 7. Secretion cavity. 

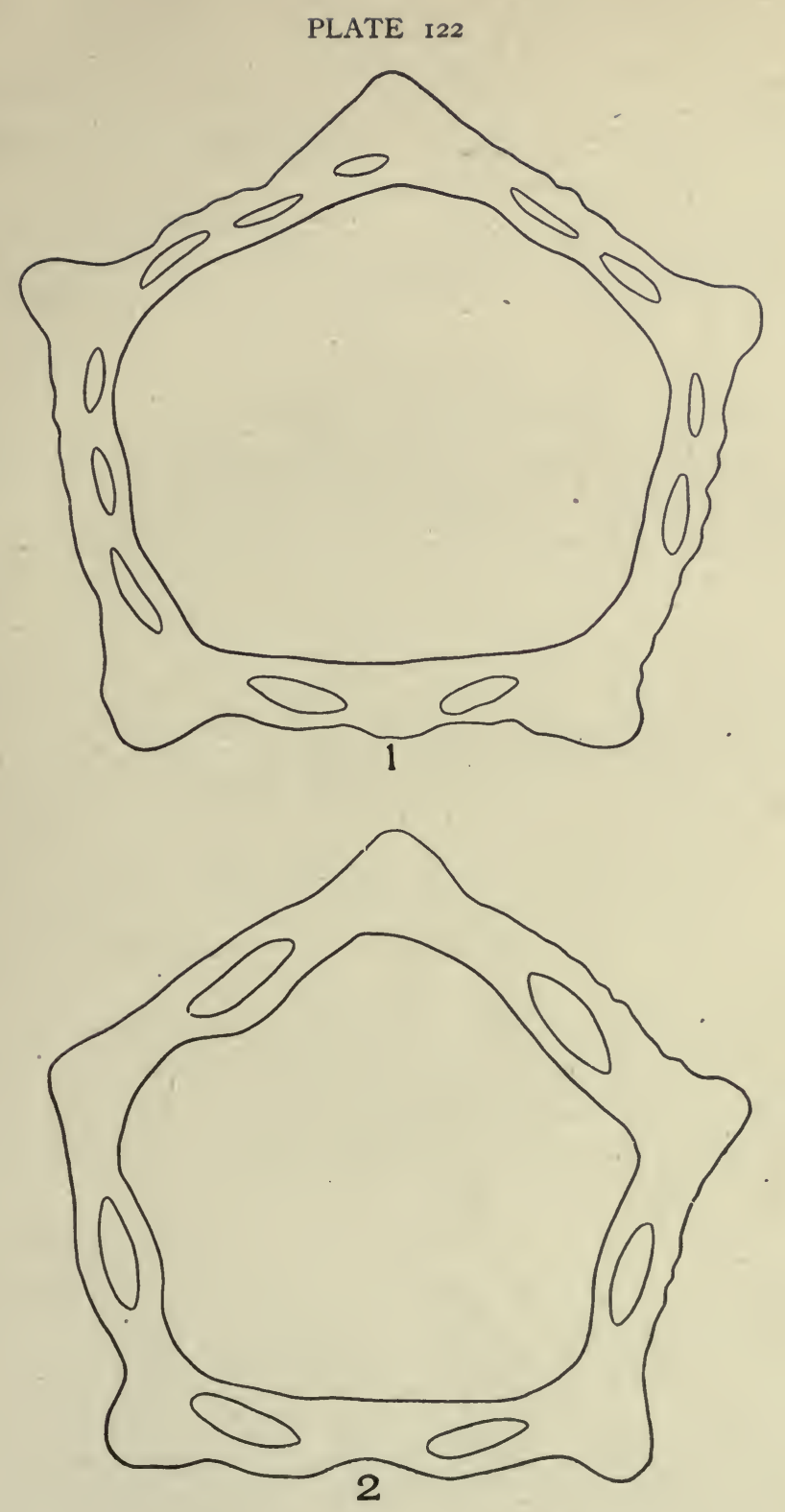

Diagrammatic Drawing of the

I. Cross-section of wild celery seed (A pium graveolens, L.).

2. Cross-section of cultivated celery seed (Apium graveolens, L.). 
vascular bundle, and between the ribs one or more secretion cavities. The vascular bundles are small and are surrounded by irregular-shaped mesocarp cells.

The secretion cavities (Fig. 7) are oval in form and the tissue bordering the cavity is reddish brown in color. The mesocarp cells around the secretion cavities are more elongated than the other mesocarp cells.

Endocarp. The endocarp cells are three layers in thickness. These cells are elongated transversely (Fig. 4).

Spermoderm. The cells of the spermoderm are indistinct, compressed, and dark brown in color (Fig. 5).

Endosperm. The endosperm cells (Fig. 6) make up the greater part of the fruit. The walls which are common to two cells are thick, non-beaded, and non-pitted, and the cavities of the cells are filled with aleurone grains.

Embryc. The embryo cells, which show only in certain sections, are similar to endosperm cells.

In anise, hops, sumac, and cumin fruits are characteristic hairs.

In star anise, sabal, allspice, cubeb, pepper, juniper, buckthorn, and phytolacca fruits are stone cells.

In cubeb, pepper, and cardamon are characteristic masses of aggregate starch.

In sabal, allspice, and juniper are characteristic secretion cells.

In all the umbelliferous fruits, with the exception of conium, are yellow to brown secretion cavities.

In cubeb and pepper is aggregate starch. Colocynth contains many single and double spiral vessels.

Bitter orange contains solitary crystals and spongy parenchyma.

When studying fruits we must consider the nature of the epicarp cells-whether simple or modified as papillæ or hairs; the form and structure of the mesocarp cells; the number, size, and structure of the vascular bundle; the size and number of the secretion cells or cavities; the number of layers and the structure of the endocarp cells; the number of layers of stone cells - when present; the color and width of the spermoderm layer; the structure and cell contents of the endosperm cells; the nature of the embryo cells, and the nature of the cell contents. 


\section{CHAPTER IX}

\section{SEEDS}

Seeds are very variable in structure, so much so, in fact, that scarcely any two seeds have a similar structure. It is necessary, therefore, when examining seeds, to compare the structure of the seed under examination with authentic plates or with the section of a genuine seed. The layers of the seed are the spermoderm, perisperm, endosperm, and embryo. In some seeds the spermoderm forms the greater part of the seed; in others the perisperm is greatest in amount; in still others the cotyledons make up most of the seed, as in the mustards. The cells forming these different layers differ in form, structure, and number; therefore it is not difficult to distinguish and to differentiate between the different seeds when viewed as a section or as a powder. Almond is studied because it has most of the layers and cells found in seeds.

\section{SPERMODERM}

The spermoderm is the thin, brown, granular-appearing skin of the almond. The layers of the spermoderm are the epidermis, the hypoderm, the middle layers, and the inner epidermis.

The epidermis consists of radially elongated, thick-walled stone cells which occur alone or in groups of two or more, but seldom as a continuous layer. The upper or outer part of the stone cells is non-porous, but the inner walls are strongly porous (Plate I23, Fig. I).

The hypoderm. The cells forming the hypoderm are compressed, the wall structure is practically indistinguishable, and the whole mass is reddish brown (Plate I23, Fig. 2).

Occurring in this brown layer are several vascular bundles (Plate I23, Fig. 3). 


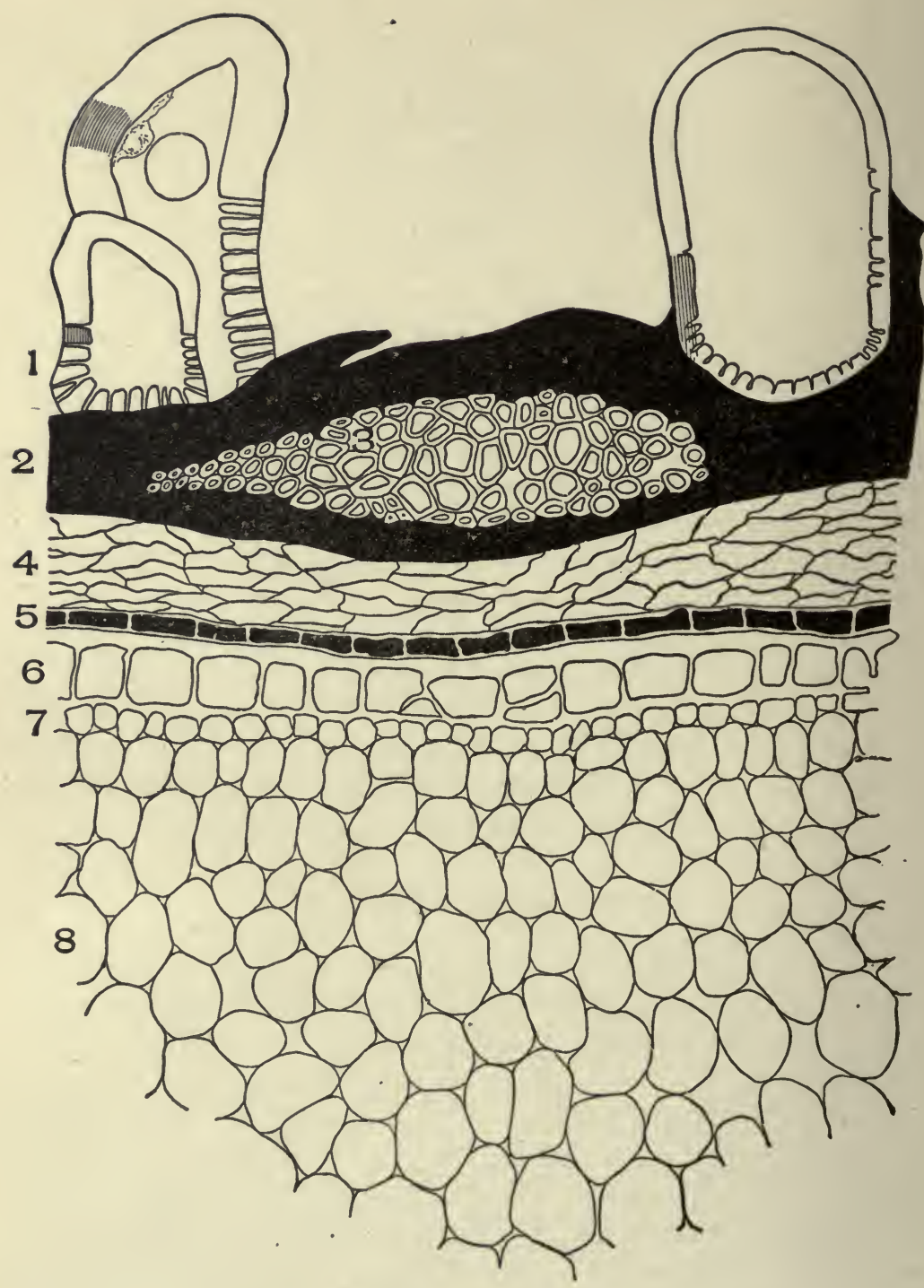

Cross-Section Sweet Almond Seed

I. Epidermis. 2. Hypoderm. 3. Vascular bundle. 4. Middle layer. 5. Inner epidermis. 6. Endosperm. 7. Outer layer of the embryo. 8. Inner layers of the embryo. 
The middle layers. The cells forming the middle layers (Fig. 4) have thin, wavy, light-colored walls which are frequently compressed, and it is with much difficulty that their outlines are made out.

The inner epidermis. The cells forming the inner epidermis are rectangular in form, and they contain reddish-brown cell contents (Plate I23, Fig. 5).

\section{ENDOSPERM}

The endosperm. The cells forming the endosperm are large, rectangular in outline, usually one layer thick, and they contain aleurone grains.

\section{EMBRYO}

The embryo. The cells forming the outer layer of the embryo are smaller than the inner layers. and they are immediately inward from the layer of endosperm cells (Plate I23, Fig. 7).

The cells forming the greater part of the embryo are large, rounded, and they contain aleurone grains and fixed oil (Plate I23, Fig. 8).

In white and black mustard are characteristic mucilage and palisade cells.

In nux vomica, stropanthus, and St. Ignatius's bean are characteristic hairs.

In physostigma and kola are characteristic starch grains.

In henbane, capsicum, stramonium, lobelia, and belladonna seeds are characteristic epidermal cells.

In areca nut, colchicum, saw palmetto, and nux vomica are characteristic thick-walled, reserve cellulose cells.

In cardamon seed are aggregate starch masses with irregular outlines.

In bitter and sweet almond, linseed, pepo, and stropanthus are aleurone grains.

In bitter and sweet almonds are stone cells.

In linseed, quince seed, and in white and black mustard are epidermal cells with mucilaginous walls and contents, etc. 


\section{CHAPTER $\mathrm{X}$}

\section{ARRANGEMENT OF VASCULAR BUNDLES}

Having familiarized ourselves with the different types of mechanical and conducting cells, we shall now consider the different ways in which these cells are associated to form the vascular and fibro-vascular bundles.

The simplest form of the vascular bundle occurs in petals, floral bracts, and leaves. In these parts the vascular bundle is made up of conducting cells only.

In the great majority of cases, however, the conducting cells are associated with mechanical cells to form the fibro-vascular bundle.

The fibro-vascular bundle is made up of, first, the phloem, which consists of sieve tubes, companion cells, bast fibres, and parenchyma; secondly, of the xylem, composed of vessels and tracheids, wood fibres and wood parenchyma; thirdly, of medullary rays (restricted to certain types); and fourthly, of the bundle sheath (restricted to certain types).

\section{TYPES OF FIBRO-VASCULAR BUNDLES}

There are three well-defined types of the fibro-vascular bundle, namely, the radial, the concentric, and the collateral types.

\section{RADIAL VASCULAR BUNDLES}

The radial type of bundle is met with most frequently in monocotyledonous roots.

In this form (Plate II4) the xylem forms radial bands of tissue which alternate with isolated groups of phloem. The space between the phloem and xylem is filled in with either parenchyma or fibres, or both. In some cases the vessels of the xylem meet in the centre of the root, while in other cases 


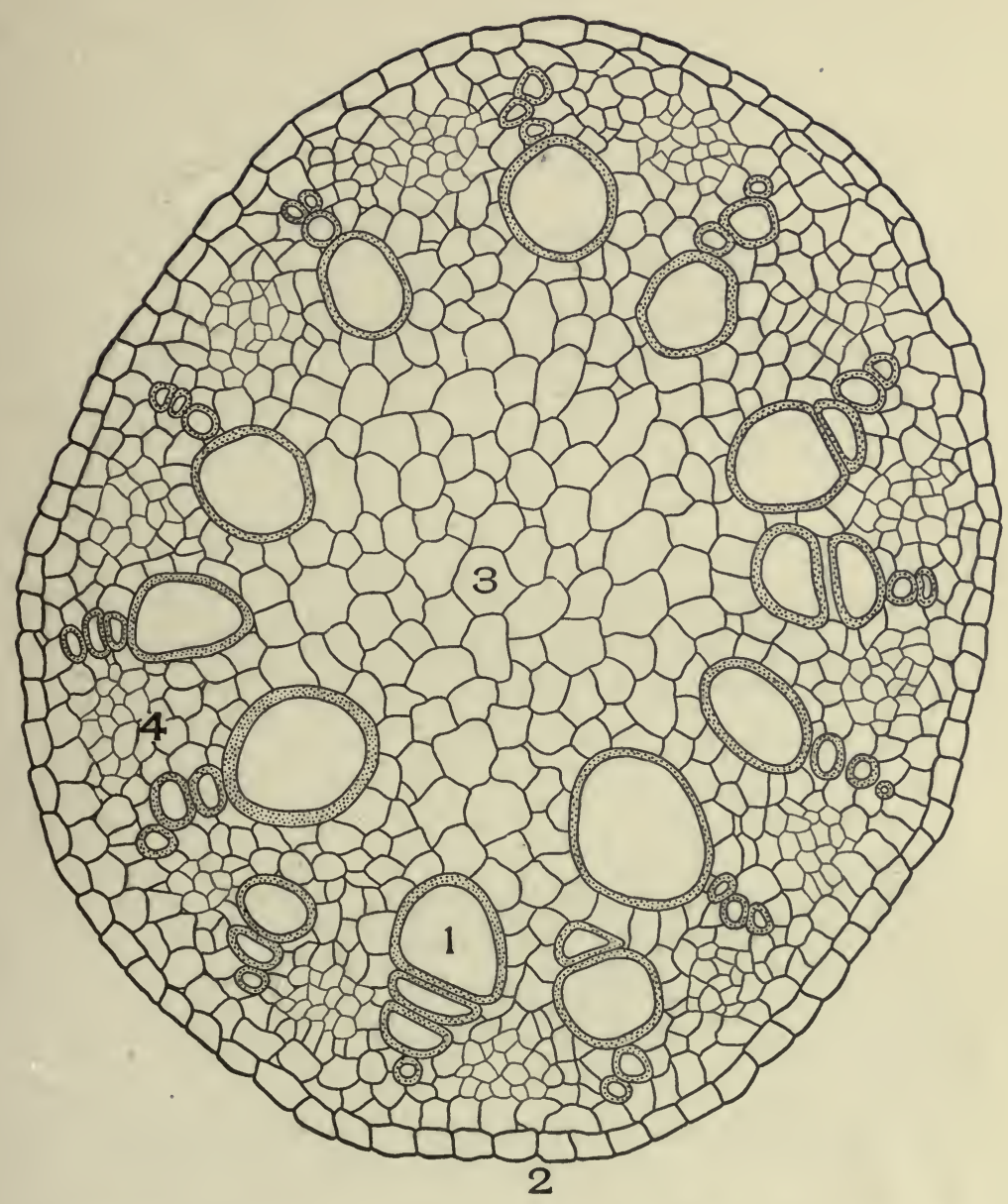

Cross-Section of -a Radial Vascular Bundle of Skunk Cabbage Root (Symplocarpus fœtidus [L.], Nutt.)

I. Vessels.

2. Bundle sheath.

3. Parenchyma.

4. Sieve cells. 


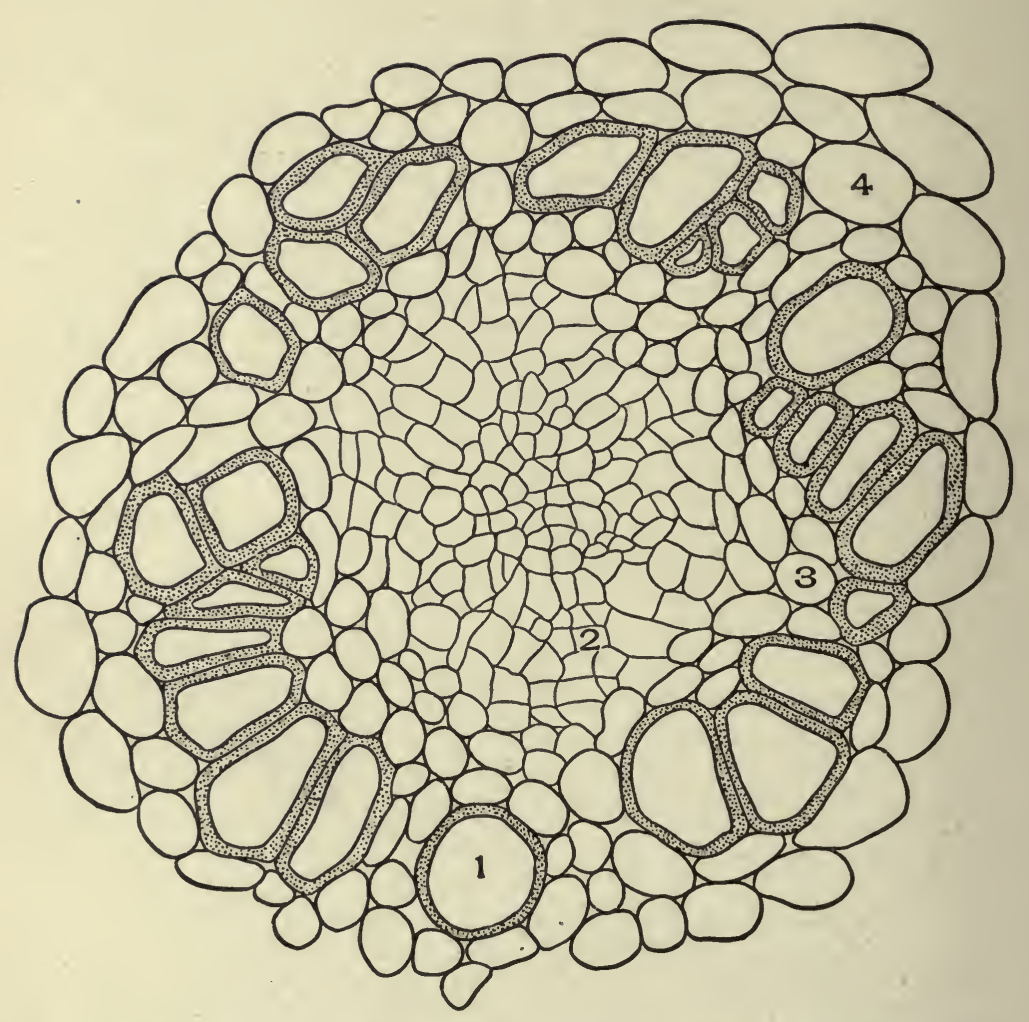

Cross-Section of a Phloem-Centric Bundle of Calamus Rhizome (Acorus calamus, L.)

I. Vessels.

2. Sieve cells.

3. Phloem parenchyma.

4. Parenchyma surrounding the bundles. 
the centre of the stem is occupied by pith parenchyma. Each bundle is surrounded by parenchyma cells, and in iris, calamus, and veratrum, rhizomes, and endodermis, surrounds the bundles located in the centre of the stem, consisting of thin-walled (mechanical) cells.

In sarsaparilla root, the pith is composed of thick-walled, porous pith parenchyma cells with starch. Outside the pith are arranged radial bands of oval vessels which decrease in size toward the periphery. Between the ends of these bands occur isolated groups of sieve cells.

Surrounding the sieve cells and vessels are thick-walled, angled fibres.

External to these cells is an endodermis composed of lignified brownish-colored cells one layer in thickness.

\section{CONCENTRIC VASCULAR BUNDLES}

There are two principal types of the concentric bundle, namely, xylem-centric, in which the xylem is centric and the phloem is peripheral, as in veratrum root; and phloem-centric (Plate 125), in which the phloem is centric and the xylem peripheral, as in calamus rhizome.

\section{COLLATERAL VASCULAR BUNDLES}

There are three types of collateral vascular bundles-namely, closed collateral, bi-collateral, and open collateral.

In the closed collateral bundle the phloem and xylem are not separated by a cambium layer, and in many cases the bundle is surrounded by thick, angled walled fibres, as in palm stem. The term closed bundle refers to the fact that there is no cambium between the xylem and phloem, therefore the bundle is "closed" to further growth, and not to the fact that it is frequently surrounded by fibres which prevent further growth. In podophyllum stem (Plate I26) the xylem portion of the bundle faces the centre of the stem and the phloem portion of the bundle faces the epidermis. The xylem and phloem are separated by a cambium layer, and both are surrounded by thick-walled angled fibres which are the chief mechanical cells of the stem. This bundle is, in fact, mechanically closed, but not physiologically because a cambium is present. 


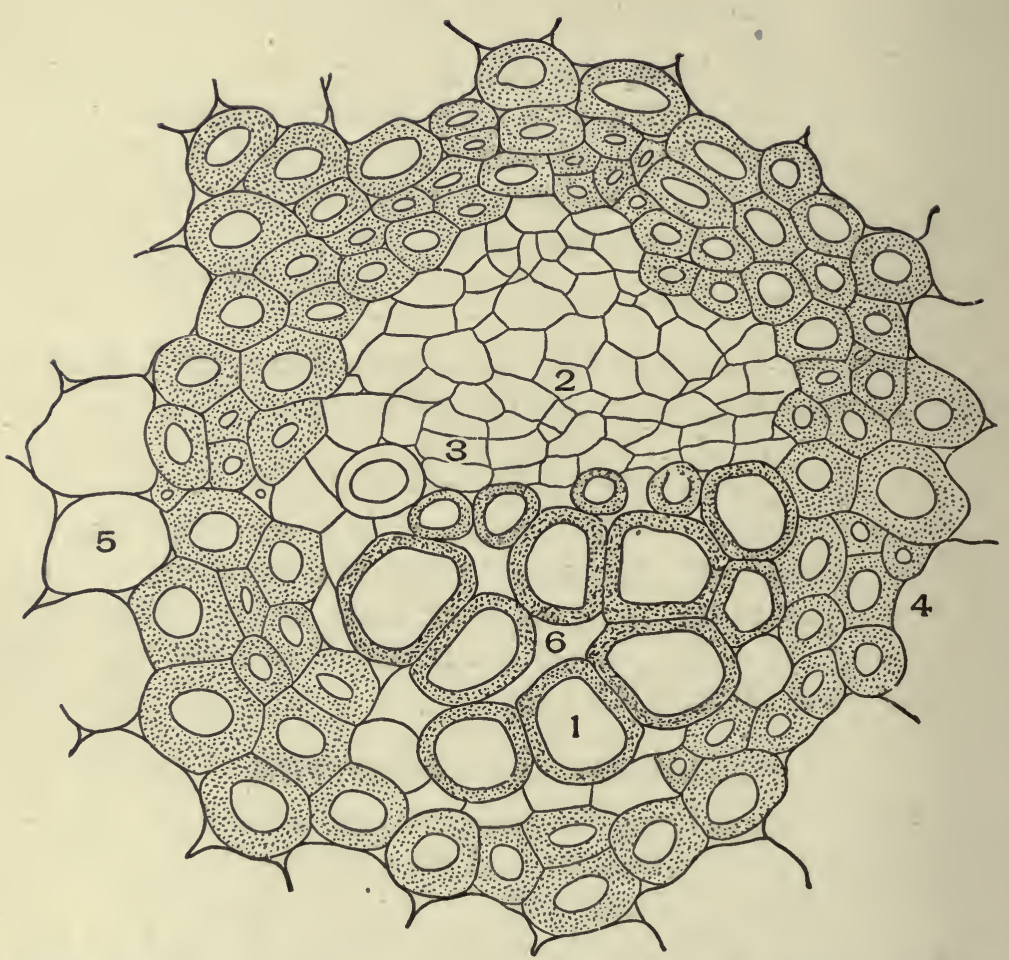

Cross-Section of a Closed Collateral Bundle of Mandrake Stem (Podophyllum peltatum, L.)

I. Vessels.

2. Sieve cells.

3. Cambium.

4. Fibres.

5. Parenchyma.

6. Intercellular space. 
PLATE 127

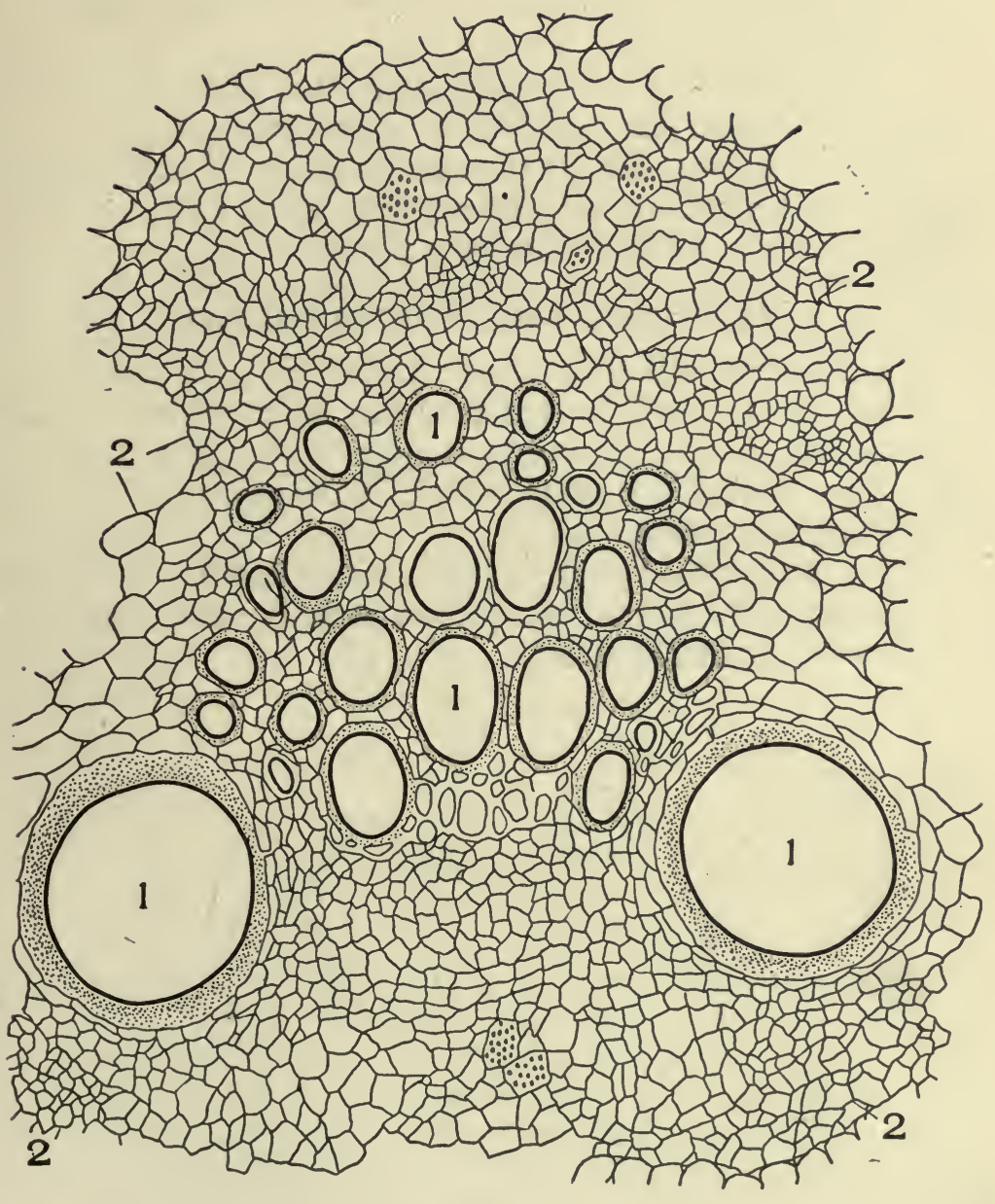

Bi-collateral bundle of Pumpkin Stem (Curcurbita pepo, L.)

I. Vessels.

2. Sieve tubes. 


\section{BI-COLLATERAL VASCULAR BUNDLES}

In the bi-collateral vascular bundle (Plate I27) the xylem is in between two groups of phloem-namely, an inner group and an outer group.

In pumpkin stem a bundle occurs in each angle of the stem. The entire bundle is surrounded by parenchyma cells.

In an individual bundle the xylem consists of large circular vessels and a phloem containing large sieve cells, many of which show the yellow porous sieve plates.

\section{OPEN COLLATERAL VASCULAR BUNDLES}

In the open collateral bundle (Plate roo) the xylem and phloem are separated by the cambium layer, which, through its divisions, causes the stem to increase in thickness each year. This type of bundle is characteristic of the stems and roots of dicotyledonous plants.

The bi-collateral bundle occurs in many leaves. The xylem in such cases is central, the phloem strands occupying upper and lower peripheral positions. 


\section{INDEX}

Abbé condenser, illustration, II

Absorption tissue, introduction, I2I tissue of leaves, 125

Aerating tissue, introduction, I5 I

Annular vessels, illustration of, I 29

Bark, of white pine powdered, description of, 250

of white pine powdered, illustration of, $25 \mathrm{I}$

unrossed white pine, cross-section, illustration of, 249

Barks, description of, 248 diagnostic structures of, 253 structural variations of, 252

Base sledge microtome, 35 sledge microtome, illustration, 35

Bast fibres, 89 branched, 92

branched, illustrations, 95

crystal bearing, 90, 92

description of, 100

groups of, illustrations, 102

non-porous and non-striated, 96 non-porous and non-striated, illustrations, Ior

non-porous and striated, 96 occurrence in powdered drugs, ro3

of barks, illustrations, 9I, 93, 94

of klip buchu leaf, 2.62

of ruellia rhizome, 226

of ruellia root, 223

of ruellia stem, 235

of spigelia stem, 235

porous and non-striated, illus-o trations, 98

porous and striated, 92

porous and striated, illustrations, 97

storage function of, 179

striated and non-porous, illustrations of, 99
Bi-collateral vascular bundles, description of, 298

Buchu stems, cross-section, illustration of, 243

cross-section, illustration of, 244 powdered, description of, 245 powdered, illustration of, 246

Cambium of pink root, 22 I

of ruellia rhizome, 226

of ruellia stem, 237

of spigelia rhizome, 223

of spigelia stem, 235

Camera lucida, 22

illustrations, 22

Care of microscope, 28

Celery fruit, diagrammatic drawing of, 287

Cell contents, 182

aleurone grains, 197

aleurone grains, description of, 198

aleurone grains, form of, 197

aleurone grains, structure of, 197

aleurone grains, tests for, 198

chlorophyll, 182

crystals, 200

crystals, composition of, 200

crystals, micro-, 200

crystals, raphides, 200

crystals, rosette, 200

crystals, solitary, variation of, 205

cystoliths, 2 IO

cystoliths, forms of, 210

cystoliths, occurrence of, 2 I 5

cystoliths, tests for, 215

hesperidin, I96

hesperdiin, test for, 196

inulin, 194

inulin, tests for, 194

leucoplastids, 183

mucilage, 194 
Cell contents, mucilage associated with raphides, tests for, 194 mucilage, tests for, 194 organic, 182 starch grains, formation of, 183 starch grains, hilum nature of, 188 starch grains, hilum of, 185 starch grains, mounting of, 188 starch grains, occurrence of, 184 starch grains, outline of, 185 starch grains, size of, 185 starch grains, tests for, 188 tannin, 196 tannin, occurrence of, 196 tannin, test for, 197 volatile oil, test for, 196 volatile oils, 196

Cell division common to onion root, 56

Cell plate, 55

Cell sap, 53

Cell, typical, 53

Cell wall, 53

Chromatin, 54

Chromatin granules, 55

Chromatophores, 53

Chromosomes, 55

Closed collateral bundles of mandrake stem, cross-section illustration of, 296

Collateral vascular bundles, 295

Collenchyma cells, composition of walls, I09

illustrations, I08

occurring in catnip and motherwort, illustrations, 107

of ruellia stem, 235

structure of, 106

Compound microscope, illustration, io microscope, mechanical parts of, 7,8

microscope of Robert Hooke, illustration, 8

microscope, optical parts of, 9 , I I, I 2

microscopes; introduction, 7

Concentric vascular bundles, 295

Conducting tissue, introduction, I26

Cork cells, origin of, 88

Cortical parenchyma, conduction by, I 47

of ruellia stem, 235
Cortex, of pink root, 219

of ruellia rhizome, 226

of ruellia root, 22 I

of ruellia stem, 235

of spigelia rhizome, 223

of spigelia stem, 233

Cover glasses, 43 illustrations, 44

Crystal cavities, I76 cells, storage function of, I 79

Cutting sections, 3 I

Cystoliths, illustrations of, 2 I4

Cytoplasm, 53

Daisies, white, powdered, description of, 282

illustration of, 283

Dissecting microscope, illustration, 5 needles, 46

needles, illustration, 46

Drawing apparatus, illustration, 23

Ectoplast, 53

Embryo, diagnostic structures of, 291

Endocarp of celery fruit, 288

Endodermal cells, illustrations of longitudinal sections, II9

illustrations of cross-sections, I I 7 introduction, II 6

structure of, I 16, I 18

Endodermis, of klip buchu leaf, 262

of pink root, 219

of ruellia root, 223

Endosperm of celery fruit, 288 of seeds, 29I

Epicarp of celery fruit, 285

Epidermal cells of leaves, storage function of, 179

Epidermis, surface deposits of, 62

of herbaceous stems, illustrations of, 152

of klip buchu leaf, 260

of leaves, illustrations of, I 55

of mountain laurel, 264

of pink root, 219

of ruellia rhizome, 226

of ruellia root, 22 I

of ruellia stem, 235

of seeds, 289

of spigelia rhizome, 223

of spigelia stem, 233

of testa, 63 
Epidermis of trailing arbutus, 264

Equatorial plane, 55

$$
\text { plate, } 55
$$

Fibro-vascular bundles, composition of, 292

of klip buchu leaf, 262

types of, 292

Flowers, diagnostic structures of, 284

parts of, 270

Folding magnifier, 4

illustration, 4

Fruits, cellular structure of, 285 diagnostic characteristics of, 288

diagnostic structures of, 288

Glandular hairs of peppermint, I78

illustrations of, 165

multicellular, I64

multicellular, multiseriate stalked, I66

multicellular, multiseriate stalked, description of, 166

multicellular, multiseriate stalked, occurrence, 166

multicellular sessile, I 64

multicellular stalked, I64

multicellular, uniseriate stalked, I64

stalked, illustrations of, 167

storage function of, 178

unicellular, I64

unicellular, multiseriate stalked, I64

unicellular sessile, $\mathrm{I}_{4}$

unicellular stalked, 164

unicellular, uniseriate stalked, I 64

Glandular tissue, introduction, 164

Glass slides, 44

illustrations, 44

Greenough binocular microscope, 15 illustration, 15

Guard cells, 15I

Hairs, multicellular, multicellular non-branched, illustration, 75 multicellular, multiseriate branched, of Shepherdia, 78

multicellular, multiseriate branched, 77,82

multicellular, multiseriate branched, illustrations, 79, 8I
Hairs, multicellular, multiseriate nonbranched, 74

multicellular, uniseriate branched, illustration, 76

multicellular, uniseriate $\mathrm{n}$ o $\mathrm{n}$ branched, 72

multicellular, uniseriate n o $\mathbf{n}$ branched, illustrations of, 73

Hand cylinder microtome, illustration, 34

microtome, 3 I

microtome, illustration, 31

table microtome, 34

table microtome, illustration, 34

Horehound, powdered, description of, 237

powdered, illustration of, 238

spurious, powdered, description of, 237

spurious, powdered, illustration of, 239

Hypoderm of seeds, 289

Hypodermal cells, of leaves, storage function of, I79

illustrations, 120

structure of, 118

Hypoderms, of klip buchu leaf, 260

of ruellia root, $22 \mathrm{I}$

Illumination for microscope, 26

Indirect cell division, 54,55

Inner bark of white pine, 248

epidermis of seeds, $29 \mathrm{I}$

Insect flower leaves, powdered, illustrations of, 268

stems, description of, $24 \mathrm{I}$

stems, powdered, illustration of, 240

Insect flowers, closed, powdered, illustration of, 279

open, description of, 280

open, powdered, illustration of, 28 I

powdered, description of, 278

Intercellular spaces, 158

illustrations of, I60, $16 \mathrm{I}$

Internal phloem, of spigelia stem, 235

Inulin, illustrations of, 195

Karyokinesis, 54, 55

Klip buchu, cross-section, illustration of, 261

powdered, description of, 262

powdered, illustration of, 263 
Labeling, 47

Latex cavities, 176

tube cavities, 176

tubes, I 42 , I 44

tubes, illustration of, 145

vessels, illustrations of, I 46

Leaf epidermis, 59 illustrations, $60,6 \mathrm{I}$

Leaf parenchyma, conduction by, 150

Leaves, diagnostic structures of, 267 stomata, 260

Lenticel, illustration of cross-section, I 59

Lenticels, ærating function of, $\mathrm{I} 57$ structure of, 158

Linin, 54

Long paraffin process, 29

Machine microtomes, 32

Measuring cylinder, 40 illustration, 40

Mechanical stage, 2 I stage, illustration, 22 tissue, 89

Medullary ray, I39

bundle, 139

bundle in tangential-section of quassia wood, 258

cell, I4I

cell, arrangement of, in the ray, I 42

cell, structure of, 142

cells, in cross-section of quassia wood, 254

cells, in radial-section of quassia wood, $25^{8}$

cells, in tangential-section of quassia wood, 258

cells, of ruellia stem, 237

Medullary rays, illustration of crosssections of, I 43

illustration of longitudinal section, 140

in cross-section of quassia wood, 254

in radial-section of quassia wood, 254

of pink root, 22I

of ruellia rhizome, 227

of ruellia root, 223

of spigelia rhizome, 226

of white pine bark, 250

Mesocarp of celery fruit, 285
Method of mounting specimens, $4 \mathrm{I}$

Micro-crystals, illustrations of, 201 lamp, 27

Micrometer eye-pieces, 21 illustrations, 20, $2 \mathrm{I}$

Microphotographic apparatus, 24 illustration, 24

Microscope, how to use, 25

Microscopic measurements, 19

Microtome, care of, 36

Middle bark of white pine, 248 lamella, 55 layers of seeds, 29I

Minor rotary microtome, 36 illustration, 36

Mountain laurel, cross-section, illustration of, 265

Mucilage cavities, 172,176

Multicellular hair, 72

Nuclear membrane, 55 spindle, 55

Nucleoli, 55

Nucleus, 53

Objectives, illustrations, II

Ocular micrometer, 19 illustration, 19

Oil cavities, occurrence, 178 of leaves, 178 of seeds, 178 , unicellular, I72 .

Open collateral vascular bundles, description of, 298

Origin of multicellular plants, 57

Outer bark of white pine, 248

Palisade parenchyma, conduction by, 150

Papillæ, 67

illustrations of, 275

of stigmas, illustrations of, 276 , 277

stigma, description of, 274

Paraffin, blocks, $3 \mathrm{I}$ embedding oven, illustration, 30

Parenchyma, aquatic plant, 150 cells of white pine, 248 conduction by, 144 cortical, illustrations of, 148 of mountain laurel, 264 of trailing arbutus, 264 pith, illustrations of, I49

Pericycle of pink root, 22 I of ruellia root, 223 
Periderm, 80

cork, 80

illustrations of, 86

of cascara sagrada, illustrations, 84

of white oak bark, illustration of, 87

parenchyma and stone cells, 85 stone cells, 85

Permanent mounts, 4I

Pharmacognostic microscope, illustration, 12

Phloem, centric bundle of calamus, cross-section, illustration of, 294

of ruellia rhizome, 226

of ruellia stem, 235

of spigelia rhizome, 223

of spigelia stem, 233

Phloem parenchyma, conduction by, 150

of pink root, $22 \mathrm{I}$

of ruellia rhizome, 226

of ruellia root, 223

of ruellia stem, 235

of spigelia rhizome, 223

of spigelia stem, 235

Photosynthetic tissue, I63

Pink root, description of, 227

Pith parenchyma, conduction by, 147

of pink root, $22 \mathrm{r}$

of ruellia rhizome, 227

of ruellia root, 223

of ruellia stem, 237

of spigelia rhizome, 226

of spigelia stem, 235

Pitted vessels, with bordered pores, illustration of, 135

illustrations of, I 34

Plant hairs, forms of, 67 introduction, 66

Polar caps, 55

Polarization microscope, 16 illustration, 16

Pollen grains, 270 non-spiny-walled, description of, 273 smooth-walled, illustrations of, 27 I

spiny-walled, description of, 273 spiny-walled, illustrations of, 272
Preparation of specimens for cutting, 28

Protoplast, 53

Quassia wood, cross-section, illustration of, 255

radial-section, illustration of, 257

Radial vascular bundles, 292

skunk cabbage root, cross-section, illustration of, 293

Raphides, illustrations of, 203

Reading glass, 4

illustration, 4

Reagent set, illustration, 39

Reagents, list of, 38

Research microscope, 13

illustration, 14

Reserve cellulose, illustrations of, I 80-18I

Reticulate vessels, illustrations of, I33

Root hairs, 121, I22, 125

illustration of, 123

illustration of fragments, 124

Roots and rhizomes, 219

diagnostic structures of, 227

Rosette and solitary crystals, illustrations of, 213

crystals, illustrations of, 204

crystals, inclosed, illustrations of, 206

Ruellia ciliosa, Pursh., powdered, illustration of, 229

ciliosa, Pursh., rhizome, crosssection, illustration of, 225

ciliosa, Pursh., stem, cross-section, illustration of, 236

root, description of, 227

root, illustration of, 222

Scalpels, 46

illustration, 47

Scissors, 46

illustration, 46

Sclariform vessels, illustrations of, 132

Seeds, parts of, 289

Secretion cavities, of celery fruit, 288 description of, 176

illustrations of, I69-171

introduction, 166

lysigenous, 168

schizogenous, 168

schizo-lysigenous, 168

unicellular, I68 
Secretion cells, of klip buchu leaf, 262 of white pine, 248

Short paraffin process, 29

Sieve cells, of klip buchu leaf, 262

of pink root, 22I

of ruellia rhizome, 226

of ruellia root, 223

of ruellia stem, 235

of spigelia stem, 235

Sieve plate, 138 illustration of, 137

Sieve tube, illustration of, 137 tubes, introduction, 136 tubes, structure, 136

Simple microscope, introduction, 3

Slide box, 48 box, illustration, 48 cabinet, 49 cabinet, illustration of, 49

forceps, 45

forceps, illustrations, 45

tray, 48

tray, illustration, 48

Solitary crystals, illustrations of, 207209, 211,212

unicellular hairs, 69

Special research microscope, 14 illustration, 14

Specimens, preservation of, 48

Spermoderm, of celery fruit, 288 of seeds, 289

Spigelia marylandica, powdered, illustration of, 228

rhizome, cross-section, illustration of, 224

root, cross-section, illustration of, 220

stem, cross-section, illustration of, 234

Spindle fibres, 55

Spiral vessels, illustrations of, 129, I 30

Spongy parenchyma of klip buchu, 260

Stage micrometer, 19

illustration, 19

Staining dish, 40

illustration, 40

Standardization of ocular micrometer, 19

Starch grains, illustrations of, 186 , I 87, I 89-1 93
Steinheil lens, 5

illustration, 5

Stems, diagnostic structures of, 233 dicotyledonous, 233

herbaceous, 233 monocotyledonous, 233

Stomata, ærating function of, 151 illustrations of cross-section, 156 relation to surrounding cells, 154 types of, 153

Stone cells, of ruellia root, 223 branched, 109 branched, illustrations of, I IO description, III, II 2 introduction, 109 occurrence, illustrations, II5 porous and non-striated, III porous and non-striated, illustrations of, II 4

porous and striated, I09

porous and striated, illustrations of, II 3

storage function of, 178

Storage cavities, I 76

cavities, illustrations of, 177

cells, 173

cells, cortical parenchyma, 173

cells, illustrations of, 174

cells, pith parenchyma, 173

cells, wood parenchyma, I 73

tissue, I73

walls, description of, 179

Stored mucilage and resin, illustrations of, 175

Surrounding cells, arrangement of, I 54

Synthetic tissue, introduction, 163

Temporary mounts, $4 \mathrm{I}$

Testa cells, 65

epidermal cells, illustrations, 64

Tracheids of pink root, 22 I

Trailing arbutus leaf, cross-section, illustration of, 266

Tripod magnifier, 4 illustration, 4

Turntable, 46 illustration, 47

Under epidermis of klip buchu leaf, 262

epidermis of mountain laurel, 264 
Under epidermis of trailing arbutus, 264

hypodermis of klip buchu leaf, 262

palisade parenchyma of klip buchu leaf, 262

Unicellular clustered hairs, 72

clustered hairs, illustrations, 7 I non-glandular hairs, 69

solitary branched hairs, 72

solitary hairs, illustrations, 70

Upper palisade parenchyma of klip buchu leaf, 260

palisade parenchyma of mountain laurel, 264

Vacuoles, 53

Vascular bundles, arrangement of, 292

occurrence of, 292

Vessels, annular, 127

and tracheids, introduction, 126

in cross-section of quassia wood, 254

in radial-section of quassia wood, 254

in tangential-section of quassia wood, $25^{8}$

of ruellia rhizome, 226

of ruellia root, 223

of ruellia stem, 237

of spigelia rhizome, 226

pitted, r 31

pitted with bordered pores, I3I

reticulate, $\mathbf{I} 3 \mathbf{I}$

sclariform, 128

spiral, 127
Water pores, arating function of, I5I

Watchmaker's loupe, 4

illustration, 4

Wood fibres, color of, $\mathrm{IO}_{4}$

illustrations, 105

in cross-section of quassia wood, 254

in radial-section of quassia wood, 258

in tangential-section of quassia wood, 258

introduction, 104

structure of, 104

Wood parenchyma, conduction by, 150

in cross-section of quassia wood, 254

in radial-section of quassia wood, 258

of pink root, $22 \mathrm{I}$

of ruellia rhizome, 227

of ruellia root, 223

of ruellia stem, 237

of spigelia rhizome, 226

of spigelia stem, 235

Woods, description of, 254

diagnostic structures of, $25^{8}$

Woody stems, buchu stem, description of, 242

mature buchu stem, 242

Xylem, of pink root, 221

of ruellia rhizome, 226

of ruellia root, 223

of ruellia stem, 237

of spigelia rhizome, 226

of spigelia stem, 235 






\section{UNIVERSITY OF CALIFORNIA}

MEDICAL SCHOOL LIBRARY

THIS BOOK IS DUE ON THE LAST DATE STAMPED BELOW

Books not returned on time are subject to a fine of $50 \mathrm{c}$ per volume after the third day overdue, increasing to $\$ 1.00$ per volume after the sixth day. Books not in de. mand may be renewed if application is made before expiration of loan period.

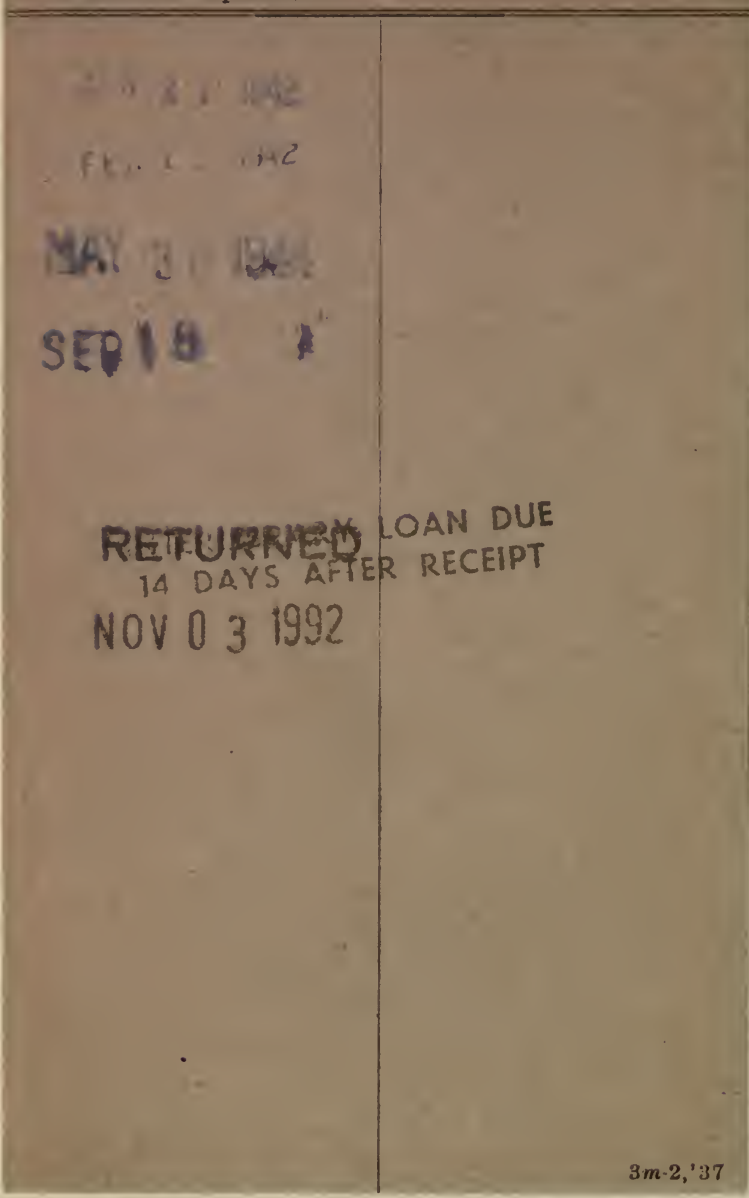

590448 


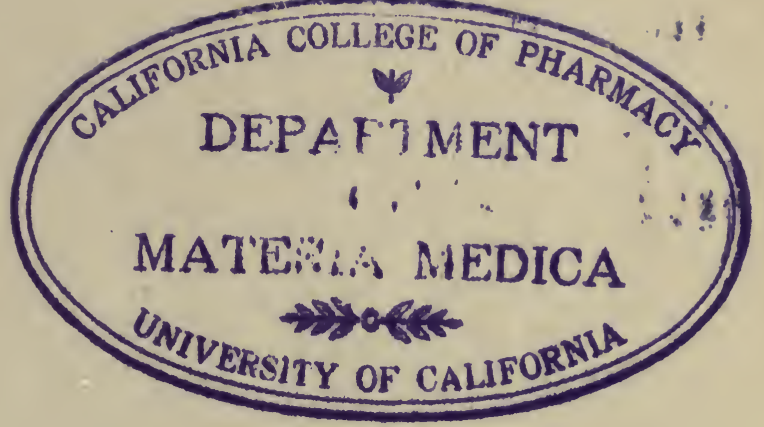

prish 
